\title{
Emigration of Natural and Hatchery Chinook Salmon and Steelhead Smolts from the Imnaha River, Oregon
}

Progress Report

\section{0 - 2002}

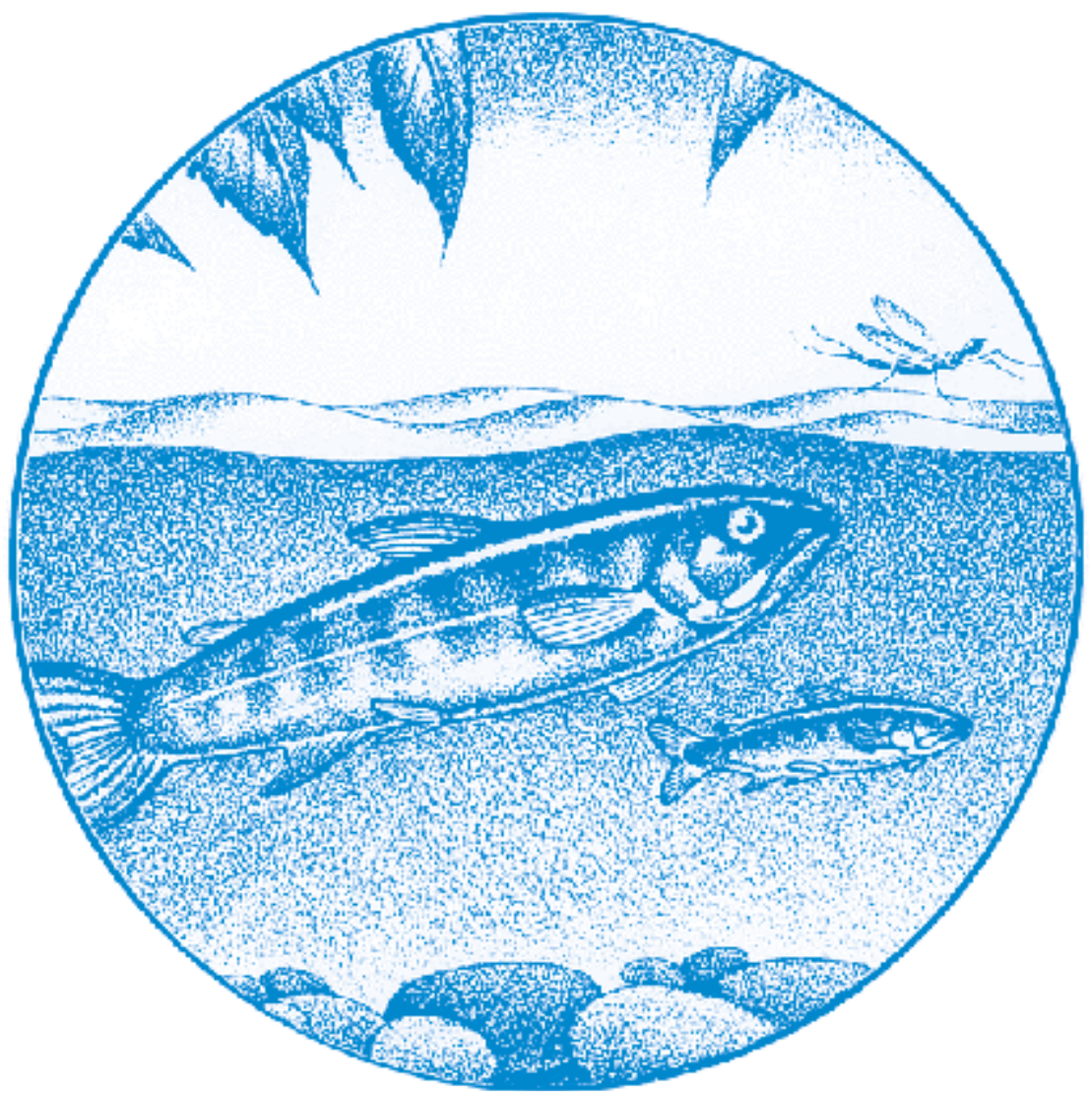

DOE/BP-00004004-2

December 2003 
This Document should be cited as follows:

Cleary, Peter, Paul Kucera, Michael Blenden, Neal Espinosa, Cameron Albee,

"Emigration of Natural and Hatchery Chinook Salmon and Steelhead Smolts from the

Imnaha River, Oregon", Project No. 1997-01501, 123 electronic pages, (BPA Report

DOE/BP-00004004-2)

Bonneville Power Administration

P.O. Box 3621

Portland, Oregon 97208

This report was funded by the Bonneville Power Administration (BPA), U.S. Department of Energy, as part of BPA's program to protect, mitigate, and enhance fish and wildlife affected by the development and operation of hydroelectric facilities on the Columbia River and its tributaries. The views in this report are the author's and do not necessarily represent the views of BPA. 


\title{
Emigration of Natural and Hatchery Chinook Salmon and Steelhead Smolts from the Imnaha River, Oregon, from October 17, 2000 to June 12, 2002
}

\author{
2001-2002 Annual Report
}

\author{
Prepared by: \\ Peter J. Cleary \\ Paul A. Kucera \\ Michael L. Blenden \\ Neal Espinosa \\ Cameron M. Albee \\ Nez Perce Tribe \\ Department of Fisheries Resources Management \\ Lapwai, Idaho 83540
}

\author{
Prepared for: \\ U.S. Department of Energy \\ Bonneville Power Administration \\ P.O. Box 3621 \\ Portland, Oregon 97208 \\ and
}

U.S. Fish and Wildlife Service

Lower Snake River Compensation Plan

1387 Vinnell Way

Boise, Idaho 83709

Cooperative Agreement for FY 2001: 14110-1-J005

Cooperative Agreement for FY 2002: 14110-2-J011

BPA Project Number: 97-015-01

BPA 2001 Contract Number: 00003087

BPA 2002 Contract Number: 00004004

December 2003 


\section{EXECUTIVE SUMMARY}

This report summarizes the emigration studies of the Nez Perce Tribe in the Imnaha River subbasin during the 2001 and 2002 migration years. A migration year for the Imnaha River is defined here as beginning July 31 of the previous year and ending July 30 the following year. The conclusion of the studies at the end of migration year 2002 marked the $11^{\text {th }}$ year of the Nez Perce Tribe's Lower Snake River Emigration Studies. The Nez Perce Tribe has participated in the Fish Passage Center's Smolt Monitoring Program for nine of the 11 years. These studies collect and tag juvenile chinook salmon and steelhead at two locations in the fall, rkm 74 and $\mathrm{rkm} 7$, and at $\mathrm{rkm} 7$ during the spring. Data from captured and tagged fish provide an evaluation of hatchery production and releases strategies, post release survival of hatchery chinook salmon, abundance of natural chinook salmon, and downstream survival and arrival timing of natural and hatchery chinook salmon and steelhead. The hydrologic conditions that migrating fish encountered in 2001 were characterized as a drought and conditions in 2002 were characterized as below average.

Hatchery chinook salmon had a mean fork length that was $34 \mathrm{~mm}$ greater in 2001 and 35 $\mathrm{mm}$ greater in 2002 than the mean fork length of natural chinook smolts. Hatchery steelhead smolt mean fork lengths were $39 \mathrm{~mm}$ greater than natural steehead smolts in 2001 and $44 \mathrm{~mm}$ greater than natural steelhead smolt fork lengths in 2002. A significant difference $(p<0.05)$ between hatchery and natural chinook salmon and steelhead fork lengths has been documented by these emigration studies from 1997 to 2002 . Hatchery chinook salmon were volitionally released in 2001 and 2002 and the $90 \%$ arrivals for 2001 and 2002 at the lower rkm 7 trap were within the range of past observations of 22 to 38 days observed in 1999 and 2000. We estimated that $93.9 \%$ of the 123,014 hatchery chinook salmon released in 2001 survived to the lower trap and $90.2 \%$ of the 303,769 hatchery chinook salmon released in 2002 survived to the lower trap. Post release survival estimates for hatchery chinook salmon were within the range of past estimates; $88.4 \%$ in 1998 to $100.9 \%$ in 1994. An estimated 7,646 to 23,249 (95\% C.I.) natural chinook salmon smolts migrated past the lower Imnaha River trap from April 4 to April 22. An additional 6,767 to 14,706 (95\% C.I.) natural chinook salmon smolts migrated past the lower Imnaha River trap from April 23 to May 14, 2002.

Natural chinook salmon captured and tagged at the upper rkm 74 trap survived to Lower Granite Dam (LGR) at a rate of $28.8 \%$ during migration year 2001 and $21.9 \%$ during migration year 2002. The survival estimate for fall tagged natural chinook salmon from the lower trap to LGR was $41.9 \%$ in 2001 and $33.3 \%$ in 2002. Differences between survival from release to LGR for fall tagged natural chinook salmon from the lower trap have been $5.9 \%$ to $16.9 \%$ higher than for fall tagged natural chinook salmon from the upper trap from 1994 to 2002.

Spring PIT tag release groups of natural chinook salmon, hatchery chinook salmon, and hatchery steelhead produced estimates of survival from the trap to LGR within the range of past estimates since 1993. Estimated survival from release to LGR for 2001 and 2002 were as follows: $83.7 \%$ and $86.9 \%$ for natural chinook salmon, $80.3 \%$ and $77.3 \%$ for hatchery chinook salmon, $82.7 \%$ and $81.8 \%$ for natural steelhead, and $82.0 \%$ and $83.0 \%$ for hatchery steelhead. 
Estimates of survival for spring tagged fish from the trap to Lower Monumental Dam (LMO) during the drought of 2001 were the lowest estimates of survival from 1998 to 2002 for natural chinook salmon, and from 1997 to 2002 for natural and hatchery steelhead. Estimates of migration year 2001 survival from the trap to LMO were as follows: $65.6 \%$ - natural chinook salmon, $68.9 \%$ - hatchery chinook salmon, $49.7 \%$ natural steelhead, and $42.9 \%$ - hatchery steehead. Estimates of migration year 2002 survival from the trap to LMO were as follows: $76.8 \%$ - natural chinook salmon, $68.1 \%$ - hatchery chinook salmon, $69.9 \%$ natural steelhead, and $78.0 \%$ - hatchery steehead.

A smolt-to-adult return rate (SAR) index from LGR to LGR was calculated for migrating pre-smolt and smolt natural chinook salmon, that were PIT tagged in the fall and spring at the lower trap, for brood years 1996 to 1998 (migration years 1998 to 2000). The SARs are representative of in-river Imnaha natural chinook salmon. The LGR to LGR SAR index for presmolt chinook salmon is as follows: 3.08\% (BY 1996), 2.41\% (BY 1997), and 2.98\% (BY 1998). Smolt-to-adult return rate index for spring tagged smolts was lower: $1.75 \%$ (BY 1996), $2.24 \%$ (BY 1997) and 2.94\% (BY 1998).

Fall tagged natural chinook salmon from the upper and lower trap and spring tagged natural chinook salmon from the lower trap all had significantly different $(p<0.05)$ median and cumulative arrival timing at LGR during migration year 2001. There was also significantly different median and cumulative arrival timing at LGR between fall tagged natural chinook salmon from the lower trap and spring tagged natural chinook salmon from the lower trap in migration year 2002 ( $\mathrm{p}<0.05)$. The median arrival timing of fall tagged natural chinook salmon from the lower trap to LGR was April 26 and April 16 for the 2001 and 2002 migration years, respectively. This was earlier than median arrival timing for fall tagged chinook salmon from the upper trap (April 29, 2001, and May 5, 2002) and spring tagged chinook salmon (April 28, 2001, and May 5, 2002). Median arrival dates for hatchery chinook salmon at LGR of April 29 (2001) and May 7 (2002) were within the range of past median arrival dates of April 21 (1992) to May 12 (1994). Natural steelhead median arrival dates of May 14 (2001) and May 18 (2002) at LGR were also within the past range of observations at LGR of May 2 (1995) to May 26 (1993). Hatchery steelhead median arrival dates at LGR have ranged from May 15 (1998) to May 29 (1994) and median arrival dates of May 16 and May 17 for the 2001 and 2002 migration year were within this range of observations.

Natural chinook salmon released from the week of March 31 to April 28, 2001, and from March 31 to April 28, 2002, had faster weekly median travel times to LGR than hatchery chinook salmon and average weekly travel times decreased as the season progressed. Natural steelhead weekly median travel times to LGR were also faster than their hatchery cohorts from the week of April 15 to May 13, 2001 and from the week of April 28 to May 19, 2002.

The below average hydrologic conditions during the 2001 and 2002 migration years did not notably affect Imnaha River smolt performance factors of survival and arrival timing to LGR. The notable affects of the 2001 drought were seen at LMO where estimates of survival for natural chinook salmon, natural steelhead, and hatchery steelhead were the lowest observed since 1998 for natural chinook salmon, and 1997 for natural and hatchery steelhead. 


\section{TABLE OF CONTENTS}

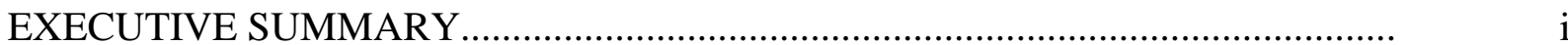

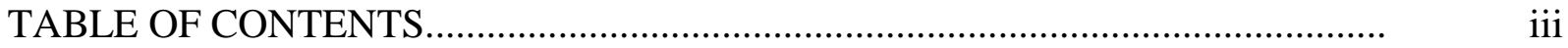

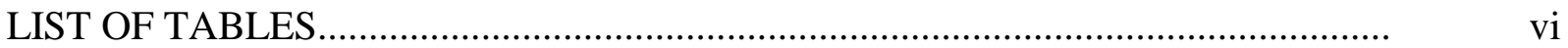

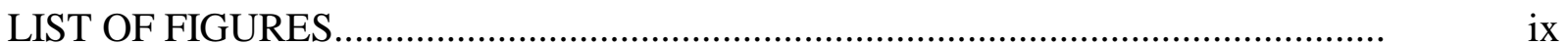

APPENDIX TABLES AND FIGURES........................................................... xii

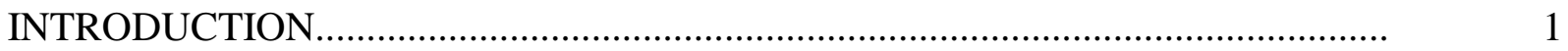

METHODS

Study Area Description......................................................................... 3

Equipment Description....................................................................

Trap Operations.................................................................................

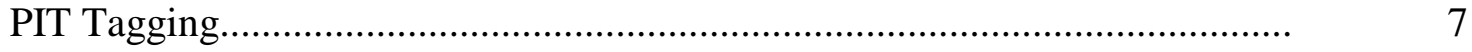

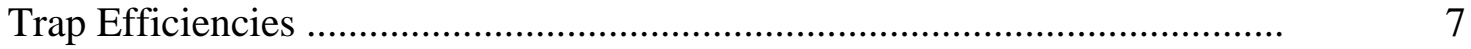

Biological Characteristics.................................................................

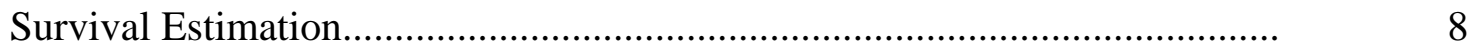

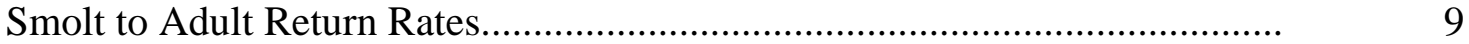

Arrival Timing and Travel Timing to Trap Site and Lower Snake River

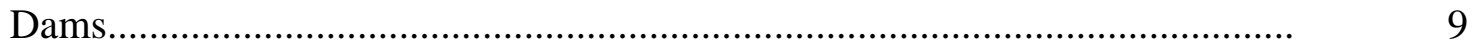

RESULTS AND DISCUSSION................................................................... 10

River Discharge and Water Temperature .............................................. 10

Imnaha River............................................................................... $\quad 10$

Snake River....................................................................... 10

Hatchery Releases.......................................................................... 16

Hatchery Chinook Salmon Releases................................................ 16

Hatchery Steelhead Releases....................................................... 16

Juvenile Chinook Salmon and Steelhead Catch.......................................... 18

Catch for Migration Year 2001..................................................... 18 
Catch for Migration Year 2002.......................................................... 20

PIT Tagging for Migration Year 2001................................................. 20

PIT Tagging for Migration Year 2002 .................................................. 23

Recaptures of Previously PIT Tagged Fish........................................... 23

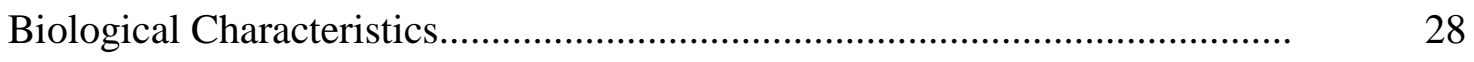

Annual Biological Characteristics....................................................... 28

Survival of PIT Tagged Smolts.................................................................. 36

Chinook Salmon Post Release Survival and Abundance...................... $\quad 36$

Estimated Season Wide Smolt Survival................................................ 37

Estimated Weekly Smolt Survival.........................................................

Smolt to Adult Return Rates...............................................................

Arrival Timing at Dams............................................................................

Natural and Hatchery Chinook Salmon Arrival Timing....................... 47

Natural and Hatchery Steelhead Arrival Timing.................................. $\quad 50$

Travel Time to Lower Granite Dam................................................... 51

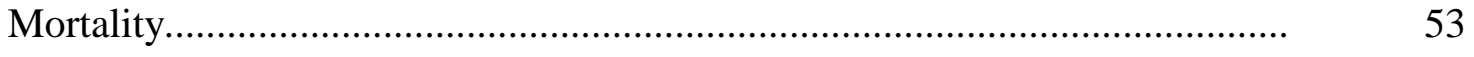

Incidental Catch................................................................................... 53

ACKNOWLEDGMENTS.............................................................................

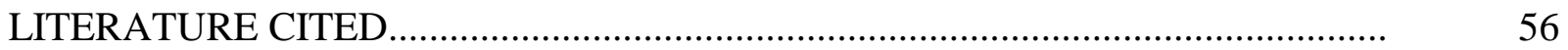

APPENDIX A. IMNAHA AND SNAKE RIVER DISCHARGE............................... A $\quad$ A 1

APPENDIX B. IMNAHA AND SNAKE RIVER TEMPERATURE DATA FOR

MIGRATION YEARS 2001 AND 2002 .......................................................... B - 1

APPENDIX C. THE CATCH OF CHINOOK SALMON AND STEELHEAD FOR

MIGRATION YEARS 2001 AND 2002 ............................................................... C -1 
APPENDIX D. STATISTICAL COMPARISONS OF MEDIAN FORK LENGTHS OF NATURAL AND HATCHERY CHINOOK SALMON AND STEELHEAD SMOLTS CAPTURED IN THE IMNAHA RIVER SMOLT TRAPS DURING MIGRATION YEARS 2001 AND 2002 …................................................................ D - D

APPENDIX E. IMNAHA RIVER JUVENILE HATCHERY CHINOOK SALMON POST RELEASE SURVIVAL ESTIMATES FROM 1994 TO 2002 AND DAILY TRAP EFFICIENCIES FOR MIGRATION YEARS 2001 AND 2002........................ E E - 1

APPENDIX F. ARRIVAL TIMING AT SNAKE RIVER AND COLUMBIA RIVER DAMS F - 1 APPENDIX G. MORTALITY AT THE IMNAHA RIVER TRAPS DURING MIGRATION YEARS 2001 AND 2002 $\mathrm{G}-1$ APPENDIX H. INCIDENTAL CATCH FOR MIGRATION YEARS 2001 AND 2002 $\mathrm{H}-1$ 


\section{LIST OF TABLES}

Table 1. Releases of hatchery reared chinook salmon and steelhead smolts in the Imnaha River Subbasin during migration years 2001 and 2002 (Oregon Dept. of Fish and Wildlife 2002 a and Oregon Dept. of Fish and Wildlife 2002 b)

Table 2. The weekly mean discharge (cfs), temperature (C) and catch of natural and hatchery chinook salmon and steelhead at the upper and lower Imnaha River from October 17 to November 15, 2000, and February 22 to June 21, 2001.

Table 3. The weekly mean discharge (cfs), temperature (C) and catch of natural and hatchery chinook salmon and steelhead at the upper and lower Imnaha River from October 17 to November 27, 2001, and March 4 to June 12, 2002.

Table 4. Weekly numbers of PIT tagged fish released from the upper and lower Imnaha River screw traps, October 17 to November 15, 2000, and February 22 to June 21, 2001

Table 5. Weekly numbers of PIT tagged fish released from the upper and lower Imnaha River screw traps, October 17 to November 27, 2001, and March 4 to June 12,2002

Table 6. Averages, ranges, and standard deviations for fork lengths ( $\mathrm{mm}$ ), weights $(\mathrm{g})$, and condition factors $(\mathrm{K})$ for PIT tag recaptures of hatchery chinook salmon, natural chinook salmon, and hatchery steelhead observed at the lower Imnaha River trap from February 22 to June 21, 2001

Table 7. Averages, ranges, and standard deviations for fork lengths (mm), weights $(\mathrm{g})$, and condition factors $(\mathrm{K})$ for PIT tag recaptures of hatchery chinook salmon, natural chinook salmon, and hatchery steelhead observed at the lower Imnaha River trap from March 4 to June 12, 2002.

Table 8. A summary of the biological characteristics of natural chinook salmon captured in the upper and lower Imnaha River screw trap from October 17 to November 15, 2000 and from October 15 to November 27, 2001. 
Table 9. A summary of the biological characteristics of natural and hatchery chinook salmon and steelhead captured in the lower Imnaha River screw trap from

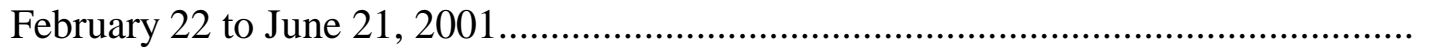

Table 10. Weekly mean fork lengths (F.L.) and condition factors (K) for natural and hatchery chinook salmon and steelhead captured at the Imnaha River trap during the

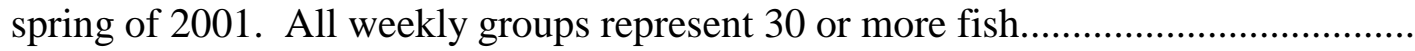

Table 11. A summary of the biological characteristics of natural and hatchery chinook salmon and steelhead captured in the lower Imnaha River screw trap from March 4 to June 12, 2002.

Table 12. Weekly mean fork lengths (F.L.) and condition factors (K) for natural and hatchery chinook salmon and steelhead captured at the Imnaha River trap during the spring of 2002. All weekly groups represent 30 or more fish..................................

Table 13. Estimated survival probabilities for season-wide PIT tag release groups of natural and hatchery chinook salmon and steelhead smolts released from the lower Imnaha River trap from February 22 to June 21, 2001 and March 4 to June 12, 2002 with 95\% confidence intervals in parentheses. Estimates are from release to the tail race for the trap to Lower Granite Dam and tail race to tail race for all other sites

Table 14. Season-wide estimates of survival from the lower Imnaha River trap to Lower Monumental Dam from 1997 to 2002. Ninety-five percent confidence intervals are shown in parentheses.

Table 15. Estimated survival probabilities for weekly PIT tag release groups of natural and hatchery chinook salmon and steelhead smolts released from the lower Imnaha River trap from February 22 to June 21, 2001 with 95\% confidence intervals in parentheses. Estimates are from release to the tail race for the trap to Lower Granite Dam and tail race to tail race for all other sites.

Table 16. Estimated survival probabilities for weekly PIT tag release groups of natural and hatchery chinook salmon and steelhead smolts released from the lower Imnaha River trap from March 4 to June 12, 2002 with 95\% confidence intervals in parentheses. Estimates are from release to the tail race for the trap to Lower Granite Dam and tail race to tail race for all other sites 
Table 17. Detections of PIT tagged Imnaha River adult chinook salmon and smolt to adult return rates (SAR \%) from the lower Imnaha River trap to Lower Granite Dam (LGR) and from LGR to LGR for brood years 1996 to 1998 .............................

Table 18. A summary of average and median annual and weekly travel times of natural and hatchery chinook salmon and steelhead released from the lower Imnaha screw trap, February 22 to June 21, 2001, at Lower Granite Dam (LGR). Weeks with less than 30 interrogations at Lower Granite Dam were not presented. Wilcoxon rank sum statistical test values represent a comparison of median natural

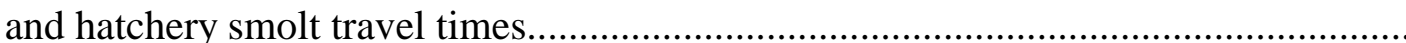

Table 19. A summary of average and median annual and weekly travel times of natural and hatchery chinook salmon and steelhead released from the lower Imnaha screw trap, March 4 to June 12, 2002, at Lower Granite Dam (LGR). Weeks with less than 30 interrogations at Lower Granite Dam were not presented. Wilcoxon rank sum statistical test values represent a comparison of median natural and hatchery smolt travel times 


\section{LIST OF FIGURES}

Figure 1. Map of the Imnaha River Study Area.....................................................

Figure 2. Map of the Columbia River Basin. Dams underlined indicate monitoring points for the Imnaha Smolt Monitoring Program

Figure 3. The lower Imnaha River trap site with two rotary screw traps operating.

Trap A is on the left and Trap B is on the right

Figure 4. The average daily discharge for 2001 and 2002 from March 1 to June 30, for the Imnaha River USGS gauge 13292000. No data was available from March 16 to March 18, 2002, and from May 14 to May 23, 2002

Figure 5. The average monthly discharge for the months of March, April, May, and June, for 2001 and 2002, at the Imnaha River USGS gauge 13292000. Bars indicate the minimum and maximum average monthly discharge values observed from 1929 to 2002 .

Figure 6. The average daily discharge for 2001 and 2002 from March 1 to June 30, for the Snake River USGS gauge 13334300

Figure 7. The average monthly discharge for the months of March, April, May, and June, for 2001 and 2002, at the Snake River USGS gauge 13334300. Bars indicate the minimum and maximum average monthly discharge values observed from 1959 to 2002 .

Figure 8. Measurements of outflow, spill, and mean temperature at Lower Granite Dam (top left), Little Goose Dam (top right), Lower Monumental Dam (lower left) and McNary Dam (lower right), from April 2 to September 2, 2001. Data was obtained on line at http://www.cqs.washington.edu/dart

Figure 9. Measurements of outflow, spill, and mean temperature at Lower Granite Dam (top left), Little Goose Dam (top right), Lower Monumental Dam (lower left) and McNary Dam (lower right), from April 2 to September 2, 2002. Data was obtained on line at http://www.cqs.washington.edu/dart 
Figure 10. The arrival frequency of previously PIT tagged hatchery chinook salmon captured in the lower Imnaha River trap during the spring of 1998 to the spring of 2002. The release strategy in 1998 was a forced release and the remainder of the

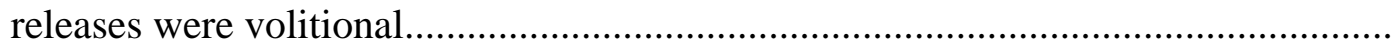

Figure 11. Length frequency distributions of natural chinook salmon trapped in the upper and lower Imnaha River traps during the fall of 2000.......................................

Figure 12. Length frequency distributions of natural chinook salmon trapped in the upper and lower Imnaha River traps during the fall of 2001......................................

Figure 13. Length frequency distribution of natural and hatchery chinook salmon trapped in the lower Imnaha River trap, February 22 to June 21, 2001

Figure 14. Length frequency distribution of natural and hatchery steelhead trapped in the lower Imnaha River trap, February 22 to June 21, 2001

Figure 15. Length frequency distribution of natural and hatchery chinook salmon trapped in the lower Imnaha River trap, March 4 to June 12, 2002............................

Figure 16. Length frequency distribution of natural and hatchery steelhead trapped in the lower Imnaha River trap, March 4 to June 12, 2002.

Figure 17. Annual survival of hatchery chinook salmon from the Imnaha River acclimation facility to the lower Imnaha River trap from 1994 to 2002. The size of annual PIT tag release groups are shown above for each year and error bars indicate

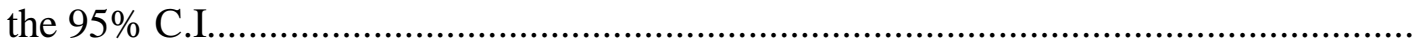

Figure 18. Estimated survival of natural chinook salmon PIT tagged in the fall and released at the upper and lower traps, to Lower Granite Dam, from migration years 1994 to 2002.

Figure 19. Season-wide survival estimates for natural chinook salmon released from the lower Imnaha River trap to Lower Granite Dam, from 1993 to 2002. Error bars indicate $95 \%$ confidence limits. The asterisk indicates upper confidence limit exceeds $100 \%$. 
Figure 20. Season-wide survival estimates for hatchery chinook salmon released from the lower Imnaha River trap to Lower Granite Dam from 1994 to 2002. Error bars indicate $95 \%$ confidence limits.

Figure 21. Season-wide survival estimates for natural steelhead released from the lower Imnaha River trap to Lower Granite Dam from 1995 to 2002. Error bars indicate $95 \%$ confidence limits

Figure 22. Season-wide survival estimates for hatchery steelhead released from the lower Imnaha River trap to Lower Granite Dam from 1995 to 2002. Error bars indicate $95 \%$ confidence limits.

Figure 23. The arrival timing of natural chinook salmon tagged in the fall of 2000 at the upper and lower trap, and in the spring of 2001 at the lower trap at Lower Granite Dam during the migration year 2001

Figure 24. The arrival timing of natural chinook salmon tagged in the fall of 2001 at the upper and lower Imnaha River traps, and natural chinook salmon tagged in the spring of 2002 at the lower trap at Lower Granite Dam in relation to the 2002 spill at Lower Granite Dam.

Figure 25. The arrival timing of hatchery chinook salmon and natural and hatchery steelhead tagged in the spring of 2002 at the lower trap, at Lower Granite Dam, in relation to the 2002 spill at Lower Granite Dam 


\section{LIST OF APPENDIX TABLES}

Appendix A. Table A1. The mean daily discharge for the Imnaha River gauge 13292000 from October 14 to November 24, 1928 to 2001, and October 14 to

November 24, 2000 and 2001

Appendix A. Table A2. The mean daily discharge for the Imnaha River gauge 13292000 from 1928 to 2001 and 2002, and the mean daily discharge for the Snake River gauge 13334300 from 1958 to 2001 and 2002 for the month of March.

Appendix A. Table A3. The mean daily discharge for the Imnaha River gauge 13292000 from 1928 to 2001 and 2002, and the mean daily discharge for the Snake River gauge 13334300 from 1958 to 2001 and 2002 for the month of April.....

Appendix A. Table A4. The mean daily discharge for the Imnaha River gauge 13292000 from 1928 to 2001 and 2002, and the mean daily discharge for the Snake River gauge 13334300 from 1958 to 2001 and 2002 for the month of May......

Appendix A. Table A5. The mean daily discharge for the Imnaha River gauge 13292000 from 1928 to 2001 and 2002, and the mean daily discharge for the Snake River gauge 13334300 from 1958 to 2001 and 2002 for the month of June

Appendix A. Table A6. Average monthly discharge for the Imnaha River from 1929 to 2002 at USGS Gauge 13292000 and the Snake River from 1959 to 2002 at USGS gauge 13334300 . A -8

Appendix B. Table B1. Mean daily temperature for the Imnaha River from October 15 to November 20, 2000 and from October 14 to November 24, 2001 at the lower Imnaha River trap.

Appendix B. Table B2. Mean daily temperature for the Imnaha and Snake rivers from February 18, 2001 to February 28, 2001 
Appendix B. Table B4. Mean daily temperature for the Imnaha and Snake rivers

Appendix C. Table C1. The catch of natural and chinook salmon and steelhead at the upper and lower Imnaha River traps from October 17 to November 15, 2000......

C -2

Appendix C. Table C2. The catch of natural and hatchery chinook salmon and steelhead at the Imnaha River traps, A and B, from February 22 to June 21, 2001 (daily samples may exceed 24 hours if sampling continued into the following day)...

C -3

Appendix C. Table C3. The catch of natural and chinook salmon and steelhead at the upper and lower Imnaha River traps from October 17 to November 27, 2001......

Appendix C. Table C4. The catch of natural and hatchery chinook salmon and steelhead at the Imnaha River traps, A and B, from March 4 to June 12, 2002 (daily samples may exceed 24 hours if sampling continued into the following day)

Appendix C. Table C5. PIT tagged recaptured natural chinook salmon in the lower Imnaha River trap during the fall for migration years 2000 and 2001

Appendix D. Table D1. Statistical comparisons of median fork lengths between treatment and control groups of smolts captured in the Imnaha River smolt traps during migration years 2001 and 2002.

D - 2

Appendix E. Table E1. The mean trap efficiency, PIT tag interrogation percentage and estimated survival of hatchery chinook salmon from release at the Imnaha River Acclimation Facility at river kilometer 74 to the Imnaha River trap at river kilometer 7, and from release to Lower Granite Dam from 1994 to 2002.

Appendix E. Table E2. Daily trap efficiency trials of hatchery chinook salmon released and recaptured in the lower Imnaha River trap during the spring of 2001 migration year.

Appendix E. Table E3. Daily trap efficiency trials of hatchery and natural chinook salmon released and recaptured in the lower Imnaha River trap during the spring of 2002 migration year 
Appendix F. Table F1. A statistical comparison of median arrival times of natural chinook salmon at Lower Granite Dam between groups of natural chinook salmon released at the upper and lower Imnaha River traps and between fall and spring releases for migration years 2001 and 2002

Appendix F. Table F2. A statistical comparison of cumulative arrival timing of natural chinook salmon at Lower Granite Dam between groups of natural chinook salmon released at the upper and lower Imnaha River traps and between fall and spring releases for migration years 2001 and 2002

Appendix F. Table F3. Arrival timing of PIT tagged Imnaha River natural chinook salmon smolts, tagged and released in the fall at the upper trap site at Lower Granite, Little Goose, Lower Monumental, and McNary dams from 1998 to 2002.....

Appendix F. Table F4. Arrival timing of PIT tagged Imnaha River natural chinook salmon smolts, tagged and released in the fall at the lower trap site at Lower Granite, Little Goose, Lower Monumental, and McNary dams from 1998 to 2002 .

Appendix F. Table F5. Arrival timing of spring PIT tagged Imnaha River natural chinook salmon smolts at Lower Granite, Little Goose, Lower Monumental, and McNary dams from 1993 to 2002.

Appendix F. Table F6. Arrival timing of PIT tagged Imnaha River hatchery chinook salmon smolts at Lower Granite, Little Goose, Lower Monumental, and McNary dams from 1992 to 2002

Appendix F. Table F7. Arrival timing of PIT tagged Imnaha River natural steelhead smolts at Lower Granite, Little Goose, Lower Monumental, and McNary dams from 1993 to 2002 .

Appendix F. Table F8. Arrival timing of PIT tagged Imnaha River hatchery steelhead smolts at Lower Granite, Little Goose, Lower Monumental, and McNary dams from 1993 to 2002 . 
Appendix G. Table G1. Mortality of chinook salmon and steelhead smolts due to trapping, handling, and PIT tagging at the upper Imnaha River trap from October 17 to November 15,2000 ...

$\mathrm{G}-2$

Appendix G. Table G2. Mortality of chinook salmon and steelhead smolts due to trapping, handling, and PIT tagging at the lower Imnaha River trap from October 17 to November 15, 2000.

Appendix G. Table G3. Mortality of chinook salmon and steelhead smolts due to trapping, handling, and PIT tagging from February 22 to June 21, 2001. $\mathrm{G}-3$

Appendix G. Table G4. Mortality of chinook salmon and steelhead smolts due to trapping, handling, and PIT tagging at the upper Imnaha River trap from October 17 to November 27, 2001

Appendix G. Table G5. Mortality of chinook salmon and steelhead smolts due to trapping, handling, and PIT tagging at the lower Imnaha River trap from October 17 to November 27, 2001

$\mathrm{G}-4$

Appendix G. Table G6. Mortality of chinook salmon and steelhead smolts due to trapping, handling, and PIT tagging from March 4 to June 14, 2002

$\mathrm{G}-4$

Appendix H. Table H1. The catch of incidental fish during the fall, October 15 to November 15, 2000, and the spring, February 22 to June 21, at the upper and lower Imnaha River juvenile fish traps for the 2001 migration year

Appendix H. Table H2. The catch of incidental fish during the fall, October 17 to November 27, 2001, and the spring, March 4 to June 12, at the upper and lower Imnaha River juvenile fish traps for the 2002 migration year. 


\section{INTRODUCTION}

This report summarizes the results of the Lower Snake River Compensation Plan (LSRCP) hatchery evaluation studies and the Imnaha River Smolt Monitoring Program (SMP) for the 2001 and 2002 smolt migration from the Imnaha River, Oregon. These studies were designed and closely coordinated to provide information about juvenile natural and hatchery chinook salmon (Oncorhynchus tshawytscha) and steelhead (O. mykiss) biological characteristics, behavior and emigrant timing, survival, arrival timing and travel time to the Snake River dams and McNary Dam on the Columbia River. Additionally, these studies are designed to provide information on listed chinook salmon and steelhead for the Federal Columbia River Power System Biological Opinion (NMFS 2000).

The Lower Snake River Compensation Plan program's goal is to maintain a hatchery production program of 490,000 chinook salmon and 330,000 steelhead for annual release in the Imnaha River (Carmichael et al. 1998, Whitesel et al. 1998). These hatchery releases occur to compensate for fish losses due to the construction and operation of the four lower Snake River hydroelectric facilities. Annual adult hatchery return goals to the Imnaha River are 3,210 chinook salmon and 2,000 adult steelhead. One of the aspects of the LSRCP hatchery evaluation studies in the Imnaha River was to determine natural and hatchery chinook salmon and steelhead smolt performance, emigration characteristics and survival (Kucera and Blenden 1998). Specifically, a long term monitoring effort was established to document smolt emigrant timing and post release survival within the Imnaha River, estimate smolt survival downstream to McNary Dam, compare natural and hatchery smolt performance, and potentially collect smolt-toadult return information.

The Smolt Monitoring Program for the Imnaha River provides information to the Smolt

Monitoring Program by Federal and Non-Federal Agencies (BPA Project No. 198712700). This larger project provides data on movement of smolts out of major drainages and past dams on the Snake River and Columbia River. Indices of migration strength and migration timing are provided for the run-at-large at key monitoring sites. Marked smolts are utilized to measure travel time and estimate in-river survival through key index reaches. Fish quality, descaling, and gas bubble trauma measures are taken on fish at each monitoring site, and provide indicators of the health of the run. These data are used for in season shaping of flow and spill management requests, and implementation of the NMFS (2000) Biological Opinion measures relative to flow and spill improving smolt passage.

Co-managers in the Imnaha River subbasin (Bryson et al. 2001) have identified the need to collect information on life history and movement patterns of steelhead, juvenile migration patterns for both steelhead and chinook salmon, juvenile emigrant abundance, reach specific smolt survivals, and smolt to adult return rates (SAR's). The current study provides information related to most of these identified priority data needs. Additional monitoring and evaluation efforts are needed to quantify juvenile emigrant abundance and SAR rates, because current funding does not allow for determination of juvenile emigrant abundance, and installation of 
adult PIT tag detectors at the mouth of the Imnaha River to calculate SAR's.

Juvenile emigrant study information collected in the Imnaha River directly responds to LSRCP and SMP program information needs. This information is shared with the Fish Passage Center (FPC) on a real time basis during the spring emigration period. The information is essential to quantify smolt survival rates under the current passage conditions, and to evaluate future recovery strategies that seek to optimize smolt survival through the hydroelectric system. Current smolt survival estimates will also provide a comparative basis for future in river smolt survival quantification and measurement of SAR rates to Lower Granite Dam. The Bonneville Power Administration (BPA) and the U.S. Fish and Wildlife Service contracted the Nez Perce Tribe (NPT) to monitor emigration timing and tag 21,200 emigrating natural and hatchery chinook salmon and steelhead smolts from the Imnaha River during the spring emigration period with passive integrated transponder (PIT) tags.

The completion of trapping in the spring of 2002 marked the eleventh year of emigration studies on the Imnaha River, and the ninth year of participating in the FPC smolt monitoring program. Monitoring and evaluation objectives were to:

1. Determine spring emigration timing of chinook salmon and steelhead smolts collected at the Imnaha River trap.

2. Evaluate effects of flow, temperature and other environmental factors on emigration timing.

3. Monitor the daily catch and biological characteristics of juvenile chinook salmon and steelhead smolts collected at the Imnaha River screw trap.

4. Determine emigration timing, travel time, and in-river survival of PIT tagged hatchery chinook salmon smolts released at the Imnaha River acclimation facility to the Imnaha River Trap.

5. Determine arrival timing, travel time and estimated survival of PIT tagged natural and hatchery chinook salmon and natural and hatchery steelhead smolts from the Imnaha River to Snake and Columbia River dams.

6. Compare emigration characteristics and survival rates of chinook salmon that may utilize the Snake River to overwinter versus overwintering in the Imnaha River. 


\section{METHODS}

\section{Study Area Description}

The Imnaha River subbasin is located in northeastern Oregon (Figure 1) and encompasses an area of approximately 2,538 square kilometers. The mainstem Imnaha River flows in a northerly direction for $129 \mathrm{~km}$ from its headwaters in the Eagle Cap Wilderness Area to its confluence with the Snake River (James 1984; Kucera 1989). The Snake River is 1,607 km long and is the longest tributary to the Columbia River. The Columbia River is the largest river in the Pacific Northwest, 1,953 km in length, and drains an area of 667,931 square kilometers from the Cascade Mountains to the west, Rocky Mountains to the east, and the Great Basin to the south (Anonymous a 2003). The source of the Columbia River is north of Oregon in Canada and is at an elevation of $809 \mathrm{~m}$. The Columbia River runs south of the Canadian border and turns west at the confluence of the Snake River (Figure 2). Annual average discharge at the mouth is approximately $275,000 \mathrm{cfs}(7,787 \mathrm{cms})$.

Reservoirs encountered by migrating Imnaha River chinook salmon and steelhead smolts are formed by Lower Granite Dam (LGR), Little Goose Dam (LGO), Lower Monumental Dam (LMO), Ice Harbor Dam, McNary Dam (MCN), John Day Dam, The Dalles Dam, and Bonneville Dam. Juvenile emigration in this report is monitored at LGR, LGO, LMO, and MCN. Juvenile emigration at Ice Harbor Dam is not monitored because it lacks the necessary facilities. The four lower Snake River dams became operational between 1961 and 1975. McNary Dam became operational in 1953 (Anonymous b 2003).

The Imnaha River drains the eastern escarpment of the Wallowa mountains and part of an adjacent plateau located between the Wallowa River drainage to the west and Hells Canyon of the Snake River to the east (Kucera 1989). Elevations in the watershed vary from 3,048 $\mathrm{m}$ at the headwaters to about $260 \mathrm{~m}$ in lower elevations (Kucera 1989). There are diversions for irrigation upstream from the gauging site in the headwaters of the tributary Big Sheep Creek ( $\mathrm{rkm} 32)$ and Little Sheep Creek. The waters diverted from Big Sheep and Little Sheep creeks are diverted to the Wallowa River Basin (Anonymous 2000). Trapping sites are located at rkm 7 (lower site) and rkm 74 (upper site).

The 72 year (1929 - 2001) mean annual discharge of the Imnaha River is $517 \mathrm{cfs}(14.6$ cms) at Imnaha, Oregon, USGS gauge 13292000 . The minimum discharge, $16 \mathrm{cfs}(0.5 \mathrm{cms})$ was observed November 22, 1931. The maximum river discharge, $20,200 \mathrm{cfs}(572.0 \mathrm{cms})$ was observed January 1, 1997 (Anonymous 2000). Maximum river discharge generally occurs from April to June with minimum flows from August to February (Kucera 1989).

\section{Equipment Description}

Floating rotary screw traps manufactured by E.G. Solutions Inc., Corvallis, Oregon, were used to capture emigrating salmonid smolts (Figure 3). Similar traps have been used to capture 


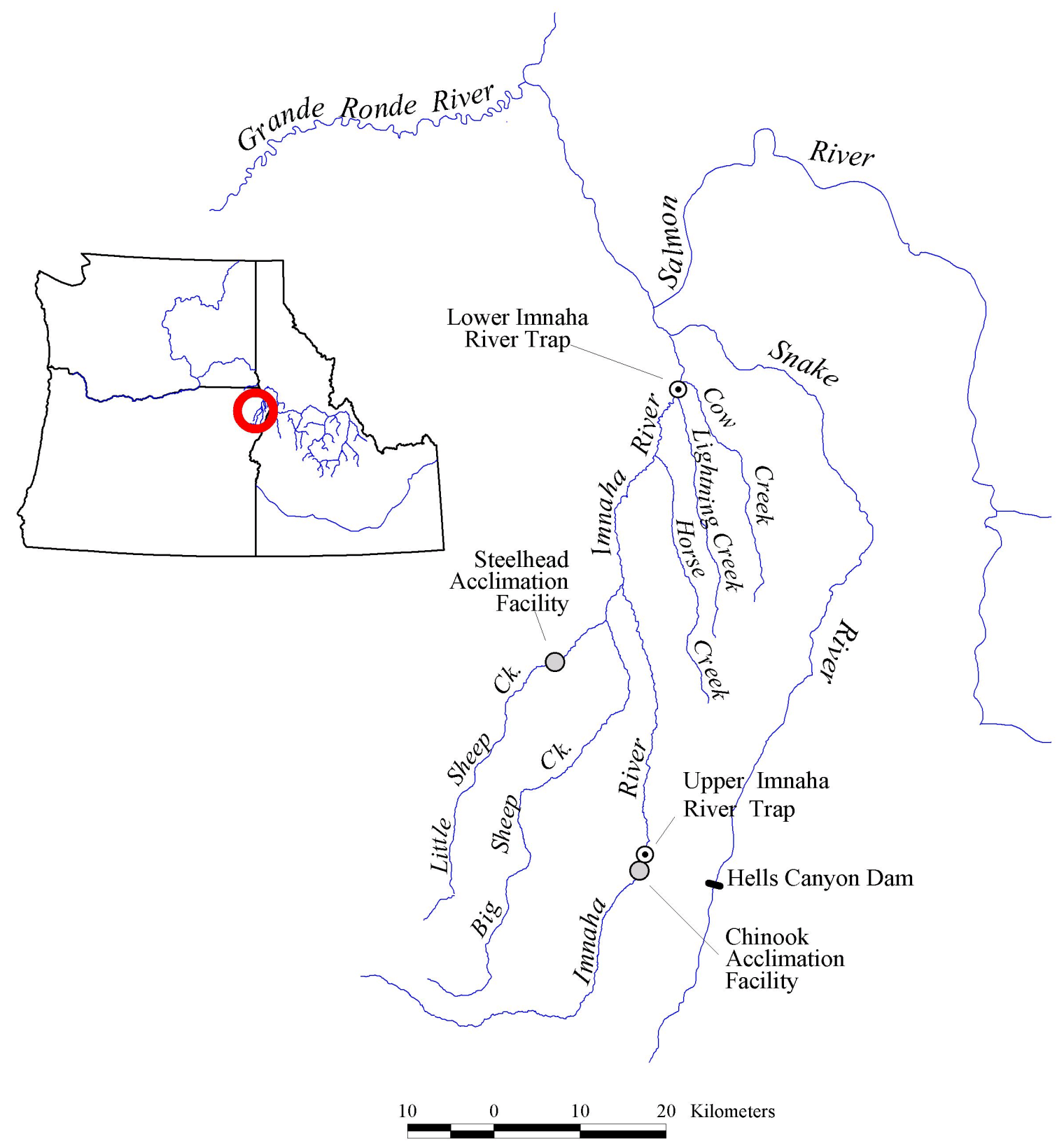

Figure 1. Map of the Imnaha River study area. 


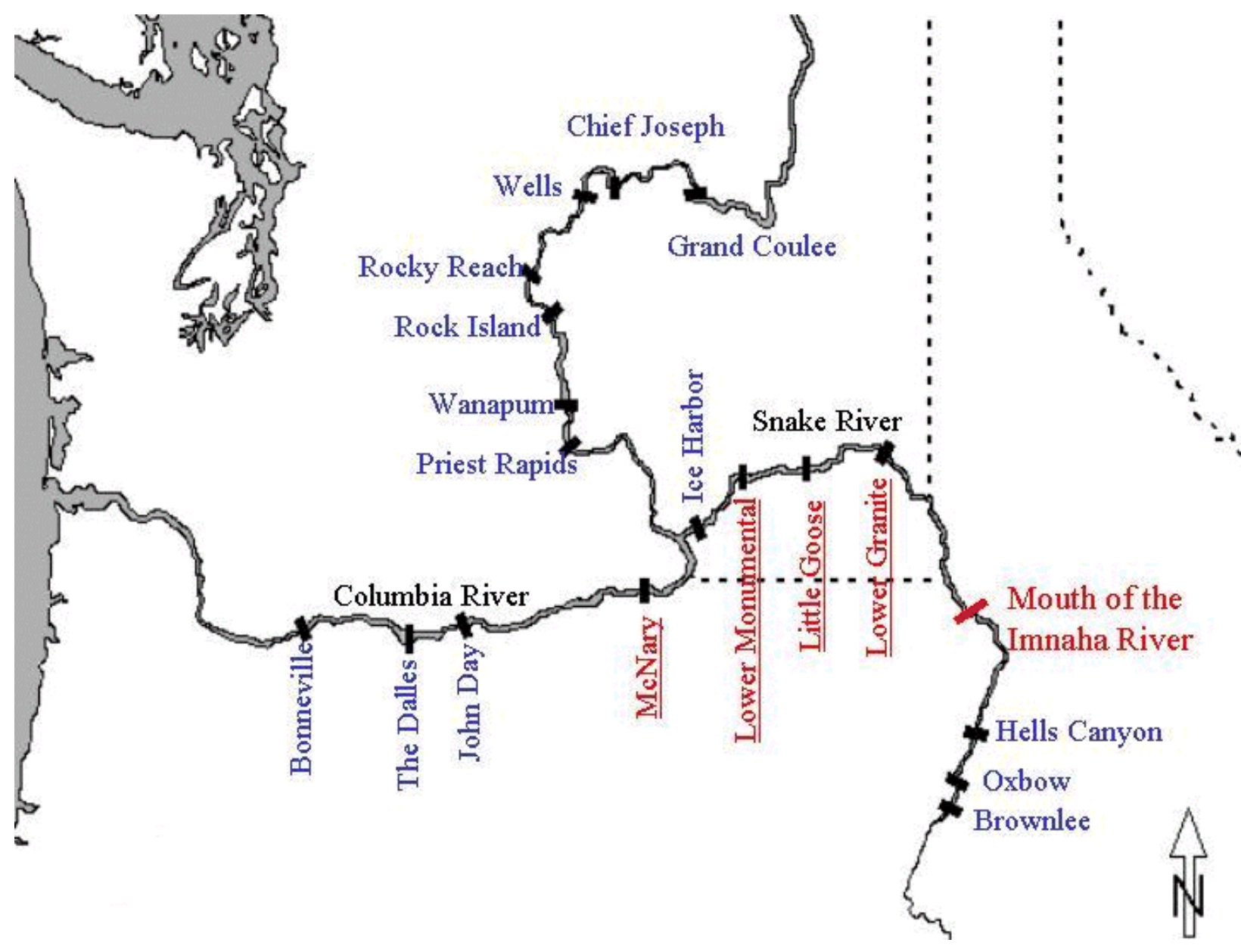

Figure 2. Map of the Columbia River Basin. Dams underlined indicate monitoring points for the Imnaha Smolt Monitoring Program.

migrating salmonid species in New York and Alaska (Kennen et al. 1994; Thedinga et al. 1994). When conditions permitted, two of these traps were fished in tandem. During hatchery releases, trap efficiency trials, high flows or periods of damage to one trap, a single trap was fished. The screw traps used in the spring and fall at the lower site consisted of a non-standard $2.1 \mathrm{~m}$ diameter trapping cone supported by a metal A-frame and two six meter pontoons that provided flotation. Fish entering the trapping cones move through to a custom oversize livebox $(1.68 \mathrm{~m}$ wide $\mathrm{x} 1.25 \mathrm{~m}$ long $\mathrm{x} 0.55 \mathrm{~m}$ deep). A sliding gate and bypass tube fitted with a PIT tag antennae and transceiver was fitted to one trap in 2002 to allow for sub sampling on an hourly bases without netting fish. The live box was fitted with a removable baffle to dissipate water velocity during high flows. A smaller trap, with a $1.5 \mathrm{~m}$ diameter cone, was used at the upper site in the fall. 


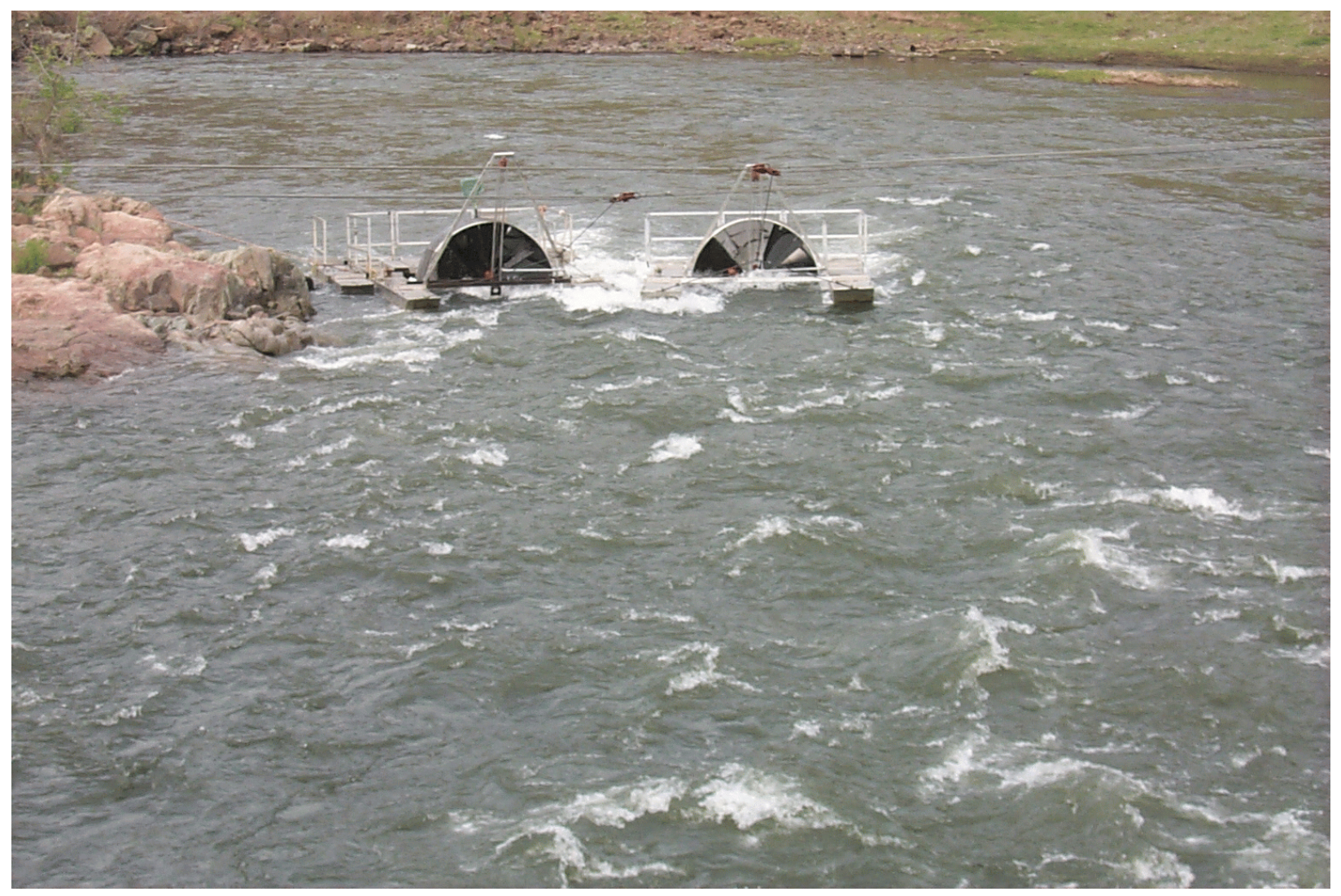

Figure 3. The lower Imnaha River trap site with two rotary screw traps operating. Trap A is on the left and trap B is on the right.

Water temperature information for this study was collected using a thermograph placed $150 \mathrm{~m}$ upstream from the screw trap. Discharge information was provided by the U.S.

Geological Survey, USGS gauge 13292000 at Imnaha, Oregon. Water discharge and temperature information were provided by the USGS for the Anatone stream gauge, 13334300.

Measurements of outflow, spill, and temperature at LGR, LGO, LMO and MCN, were obtained online from DART at http://www.cqs.washington.edu/dart.

\section{Trap Operations}

The trap at the upper site was operated from October 17 to November 9, 2000 and from October 18 to November 27, 2001. The upper Imnaha River trap was located at rkm 74 ( $400 \mathrm{~m}$ downstream of the Imnaha River chinook salmon acclimation facility). The trap was operated to collect juvenile chinook salmon for a survival estimate of presmolt survival to LGR. The lower trap was located 6.6 kilometers from the confluence to the Snake River and was operated during 
the fall from October 17 to November 15, 2000 and from October 17 to November 27, 2001. During the spring the trap was operated from February 22 to June 21, 2001, and from March 4 to June 12, 2002. The second trap at the lower site, Trap B, was operated March 16 to March 24, 2001, and May 25, and May 29 to May 30 to increase the catch of natural chinook salmon for PIT tagging purposes during the spring of 2001. It was only possible to operate Trap B April 30 to May 2 in 2002. Trap position at the lower site varied from $1 \mathrm{~m}$ (position 1) to $4 \mathrm{~m}$ (position 4), upstream or downstream with the use of a cable and pulley system. The position was recorded daily. The live box of the screw trap was checked at 0800 every morning and several times throughout each night and day. Non-target piscivorus fish and large numbers of other nontarget fish were removed from the live box first. Non-target piscivorus fish were scanned for PIT tags and then released 30-50 meters downstream. Fish were processed as they were removed from the trap.

Daily processing procedures were similar to those used by Ashe et al. (1995) and were as follows: 1) Fish were anaesthetized in a MS-222 bath (3 mL MS-222 stock solution (100 g/L) per $19 \mathrm{~L}$ of water) buffered with Propolyaqua (PRO-NOVAQUA), 2) Each fish was examined for existing marks (e.g. fin clips), and PIT tag insertion scars, 3) Chinook salmon, steelhead and large piscivorus fish were scanned with a PIT tag scanner, 4) 100 to 300 hatchery chinook salmon smolts were targeted for use in daily trap efficiency trials, 5) A specified number of each species was selected for PIT tag insertion, 6) All other fish were enumerated and released 30-50 $\mathrm{m}$ downstream from the trap after recovering from the anaesthetic, and 7) All fish mortality was recorded.

\section{PIT Tagging}

Fish selected for passive integrated transponder (PIT) tagging were examined for previous PIT tags, descaling and general health. They were measured (FL-mm) and weighed (0.1 g). All chinook salmon selected for tagging were greater than $65 \mathrm{~mm}$. Fish were PIT tagged using hand injector units following the methods described by Prentice et al. $(1986,1990)$ and Matthews et al. (1990, 1992). Hypodermic injector units and PIT tags were sterilized after each use in ethanol for at least 10 minutes prior to tagging and allowed to dry. Tagging was discontinued when water temperatures exceeded $15^{\circ} \mathrm{C}$. Steelhead smolts were held until fully recovered and then released as a group. Chinook salmon smolts were held in perforated aquatic containers for a minimum of 12 hours and released after dark. Mortality due to tagging was recorded.

\section{Trap Efficiencies}

Efficiency trials using natural and hatchery salmon were conducted during the spring. Marked fish were measured (fork length) to the nearest $\mathrm{mm}$ and weighed to the nearest $0.1 \mathrm{~g}$. Fish selected for trap efficiency trials in 2001 were marked with PIT tags or by clipping the distal portion of the fins. The following fin clips were used on a daily basis, Sunday through Saturday respectively: 1) upper and lower caudal, 2) upper caudal, 3) lower caudal, 4) left pelvic, 5) right pelvic, 6) left pectoral, and 7) right pectoral. Fish were marked with PIT tags for trap efficiency 
trials in 2002. Fish marked for trap efficiency trials were held in perforated containers in the river during daytime hours (approximately $12 \mathrm{~h}$ ) and then transported upstream, approximately one $\mathrm{km}$, during evening hours and released after dark. Trap efficiency was determined by $\mathrm{E}=$ $\mathrm{R} / \mathrm{M}$; where $\mathrm{E}$ is estimated trap efficiency, $\mathrm{R}$ is number of marked fish recaptured, and $\mathrm{M}$ is number of fish marked and released.

\section{Biological Characteristics}

Length frequency distributions were created and condition factors calculated for each target fish species and origin. Length frequencies were calculated by separating fish into $5 \mathrm{~mm}$ classes. Condition factors were calculated using Fulton's condition factor : $\left(\mathrm{W} / \mathrm{L}^{3}\right) \times 10^{5}$ (Bagenal and Tesch 1978). Natural steelhead less than $120 \mathrm{~mm}$ were assumed not to be smolts and therefore were not used in length, weight and condition factor calculations and were reported to the FPC as rainbow trout. Adult steelhead, and large steelhead that had the characteristics of resident rainbow, were not reported as juvenile steelhead or used in length, weight and condition factor calculations.

All statistics that compared fish captured and tagged during the spring were performed with STATGRAPHICS PLUS version 2 software (1995). A student t-test was used to test for significant differences in fork length between various groups of fish (i.e. natural versus hatchery steelhead smolts, previously PIT tagged hatchery chinook salmon smolts versus those not previously PIT tagged, hatchery chinook salmon marked and released for trap efficiency versus trap efficiency recaptures). Differences were considered significant at $p<0.05$. When the assumption of normality or the standard skewness was violated, the t-test was abandoned in favor of the Wilcoxon rank sum test statistic (Ott 1984). Differences were considered significant at $\mathrm{p}<$ 0.05 .

\section{Survival Estimation}

Survival probabilities were estimated by the Cormack, Jolly and Seber methodology (1964 and 1965, as cited in Smith et al. 1994) with the Survival Using Proportional Hazards (SURPH) model (Smith et. al., 1994). The data files for season wide and weekly release groups were created using the program CAPTHIST (Westhagen 1997). Data for input into CAPTHIST was obtained directly from PTAGIS. The $95 \%$ confidence intervals (C.I.) were approximated from the standard error (SE) calculated by SURPH as follows: 95\% C.I. $=\mathrm{S} \pm(1.96(\mathrm{SE})$ ), where $\mathrm{S}$ is a survival estimate of a reach.

Hatchery chinook released from the acclimation facility were treated as a single group. Season-wide and weekly release groups of natural and hatchery chinook salmon and steelhead were also treated as single release groups. Only weekly release groups of 200 or more fish were analyzed for survival on a weekly basis. The assumptions for the methodology can be found in Smith et al. 1994 and Burnham et al. 1987. When tagging chinook salmon in the fall, we assumed that fish did not migrate past LGR before PIT tag interrogation facilities became 
operational.

The point estimate of natural chinook salmon smolts migrating past the trap from March 25 to May 14 was estimated using the Bootstrap method (Efron and Tibshirani 1986). The initial population estimate was calculated as $\mathrm{N}=\mathrm{U} / \mathrm{E}$, where $\mathrm{N}$ is the total number of smolts, $\mathrm{U}$ is the number of unmarked natural chinook salmon smolts captured, and $\mathrm{E}$ is the trap efficiency estimate. Bootstrap iterations numbered 1,000.

\section{Smolt to Adult Return Rates}

An effort began in 1998 to obtain SARs to LGR for natural chinook salmon using passive integrated transponder (PIT) tags. A SARs was calculated for natural chinook salmon smolts and pre-smolts from the lower Imnaha River trap back to LGR using the ratio of number of fish released to the number of PIT tag adults detected at LGR. A LGR to LGR SAR was also calculated because it provides a more comparative SAR, given live stage survival differences. Smolt equivalents to LGR were determined by multiplying the number of fish tagged at the trap by the estimated season-wide survival to LGR for each brood year and life stage. Brood years 1996, 1997, and 1998 were analyzed.

\section{$\underline{\text { Arrival and Travel Timing to Trap Site and Lower Snake River Dams }}$}

Arrival timing to LGR, LGO, LMO, and MCN was determined for natural chinook salmon pre-smolts, natural and hatchery chinook salmon smolts, and natural and hatchery steelhead smolts. Detections and arrival timing at each dam for this report period are based on first-time observations of individual tag codes at each dam. Arrival timing estimates do not include subsequent detections of fish that were captured in the Snake River trap, held in sample rooms or raceways, had negative travel times or single coil detections. Release groups of at least 30 fish were pooled weekly to determine travel time to LGR. Travel time estimates to LGR do not include fish captured in the Snake River trap.

Arrival timing between groups of chinook salmon were compared by converting the date of individual detections for each group into a value from 1 to 365 using a perpetual day of the year calender. A Wilcoxon rank sum test statistic (Ott 1984) was then used to compare medians of each group. The commutative distributions of arrival times between groups was also compared using a Kolmogrovov-Smirnov test (Steel et al. 1997 and STATGRAPHICS 1995). 


\section{RESULTS AND DISCUSSION}

\section{River Discharge and Water Temperature}

\section{Imnaha River}

Daily discharge from October 14 to November 24, 2000 ranged from $129 \mathrm{cfs}(3.7 \mathrm{cms})$ on November 23 to $258 \mathrm{cfs}(7.3 \mathrm{cms})$ on October 29 (Appendix Table A1). Daily discharge during the spring in the Imnaha River ranged from $126 \mathrm{cfs}(3.6 \mathrm{cms})$ on March 1 to $1,150 \mathrm{cfs}(32.6 \mathrm{cms})$ on May 15 (Figure 4). Historically, daily discharge for the Imnaha River from 1929 to 2002 has ranged from $304 \mathrm{cfs}(8.6 \mathrm{cms})$ on March 4 and 5 to $1,729 \mathrm{cfs}(49.0 \mathrm{cms})$ on May 26 (Appendix Tables A2 - A5). Average monthly discharge from 1929 to 2002 for the month of March in the Imnaha River has ranged from $114 \mathrm{cfs}(3.2 \mathrm{cms})$ in 1977 to $1,026 \mathrm{cfs}(29.1 \mathrm{cms})$ in 1995 (Appendix Table A6). The average monthly discharge of $240 \mathrm{cfs}(6.8 \mathrm{cms})$ for March, 2001, was near the lower end of this range (Figure 5). Average monthly discharge from 1929 to 2002 has ranged from $345 \mathrm{cfs}(9.8 \mathrm{cms})$ in 1977 to $1,760 \mathrm{cfs}(49.8 \mathrm{cms})$ in 1956 for April, $445 \mathrm{cfs}(12.6$ $\mathrm{cms})$ in 1977 to 2,804 cfs $(79.4 \mathrm{cms})$ in 1948 for May, and $361 \mathrm{cfs}(10.2 \mathrm{cms})$ in 1992 to 2,612 cfs $(74.0 \mathrm{cms})$ in 1974 for June. The 2001 average monthly discharge for April, May, and June of $438 \mathrm{cfs}(12.4 \mathrm{cms}), 757 \mathrm{cfs}(21.4 \mathrm{cms})$, and $383 \mathrm{cfs}(10.8 \mathrm{cms})$, respectively, were visibly at the lower end of the 1929 to 2002 range of monthly average discharge values.

Water temperatures in the Imnaha River from October 15 to November 20, 2000 ranged from $-0.2{ }^{\circ} \mathrm{C}$ on November 20 to $12.0^{\circ} \mathrm{C}$ on October 19 (Appendix Table B1). The mean water temperature in the Imnaha River from February 18 to June 23,2001 , was $9.7^{\circ} \mathrm{C}$, with a minimum temperature of $2.3{ }^{\circ} \mathrm{C}$ occurring on February 28 and a maximum water temperature of $21.0{ }^{\circ} \mathrm{C}$ occurring on June 22 (Appendix Table B2 and B3).

The following migration year daily discharge in the Imnaha River, from October 14 to November 24, 2001, ranged from $112 \mathrm{cfs}(3.2 \mathrm{cms})$ on November 12 to $270 \mathrm{cfs}(7.6 \mathrm{cms})$ on October 31. The daily discharge during the spring of 2002 ranged from $135 \mathrm{cfs}(3.8 \mathrm{cms})$ on March 8 to 2,090 cfs (59.2 cms) on April 14 (Figure 4). Monthly averages for March, April, May, and June of $245 \mathrm{cfs}(6.9 \mathrm{cms}), 1,005 \mathrm{cfs}(28.5 \mathrm{cms}), 1,260 \mathrm{cfs}(35.7 \mathrm{cms})$, and 1,188 cfs (33.6 cms), respectively, were higher than the averages from the 2001 migration year (Figure 5).

Water temperatures during the fall of 2001 ranged from $3.8^{\circ} \mathrm{C}$ to $11.7^{\circ} \mathrm{C}$ (Appendix B1). The minimum water temperature during the spring of 2002 was $1.4{ }^{\circ} \mathrm{C}$ on March 3 and the maximum water temperature was 14.7 on June 15, 2002 (B4).

\section{$\underline{\text { Snake River }}$}

Daily discharge in the Snake River during the spring of 2001 ranged from 13,500 cfs (382.3 cms) on March 2 to 58,000 (1,642 cms) on May 17 (Figure 6). Average monthly discharge from 1959 to 2002 has ranged from 18,680 cfs $(529.0 \mathrm{cms})$ to $90,400 \mathrm{cfs}(2,559.8 \mathrm{cms})$ for March (Figure 7). Average monthly discharge from 1959 to 2002 has ranged from 


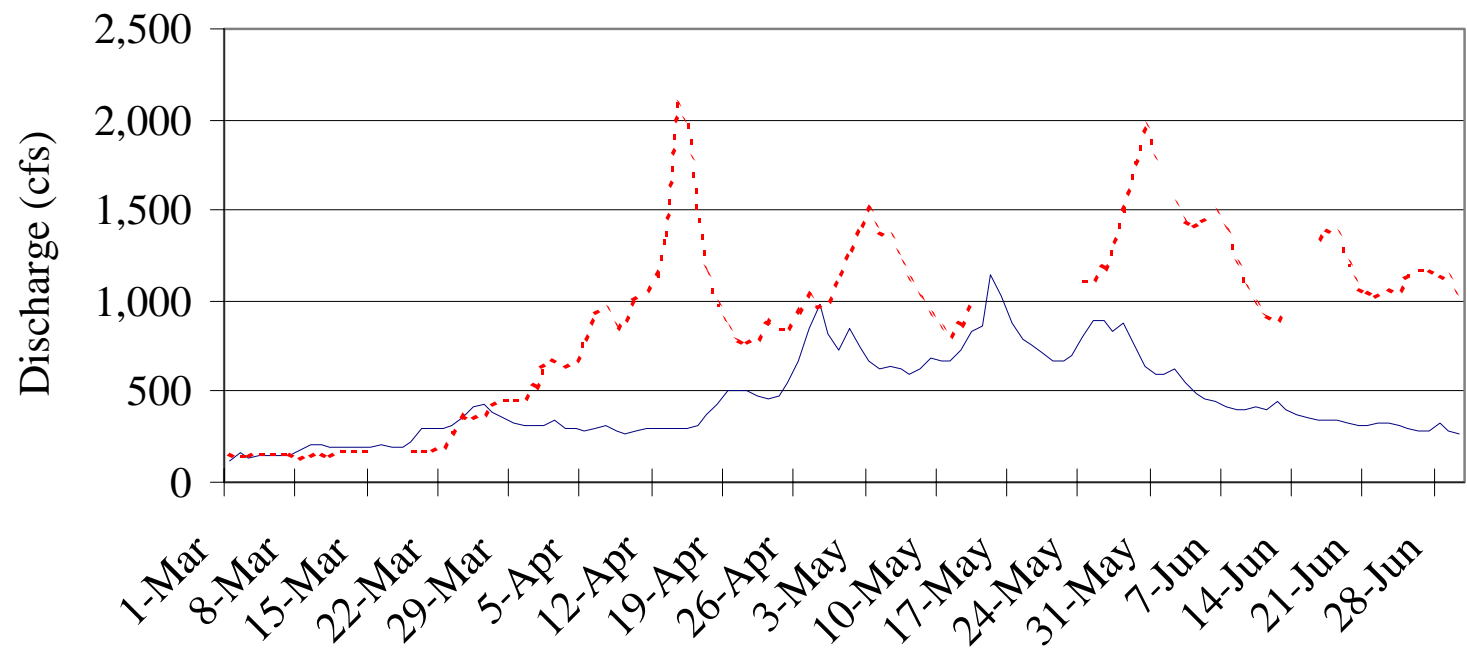

Date

Figure 4. The average daily discharge for 2001 and 2002 from March 1 to June 30, for the Imnaha River USGS gauge 13292000. No data was available from March 16 to March 18, 2002, and from May 14 to May 23, 2002.

○ 2001

$\square 2002$

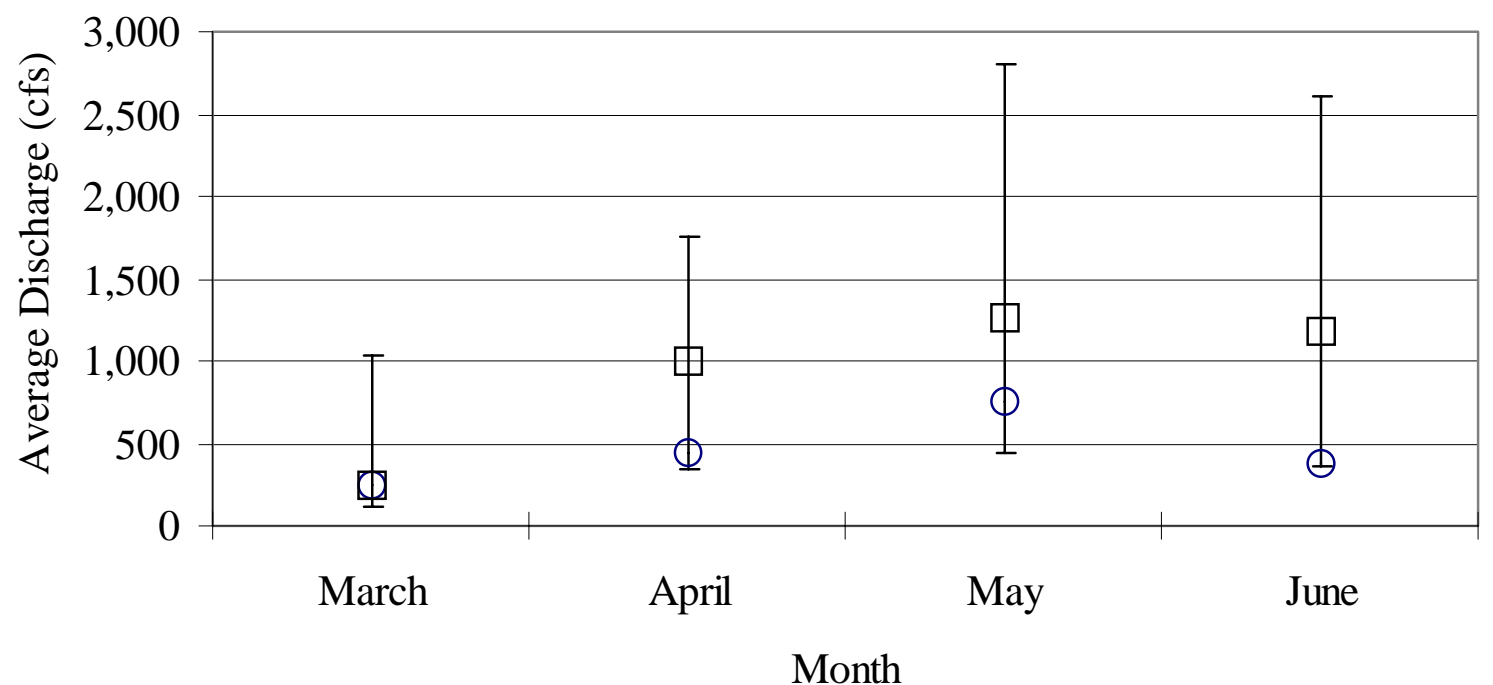

Figure 5. The average monthly discharge for the months of March, April, May, and June, for 2001 and 2002, at the Imnaha River USGS gauge 13292000. Bars indicate the minimum and maximum average monthly discharge values observed from 1929 to 2002. 


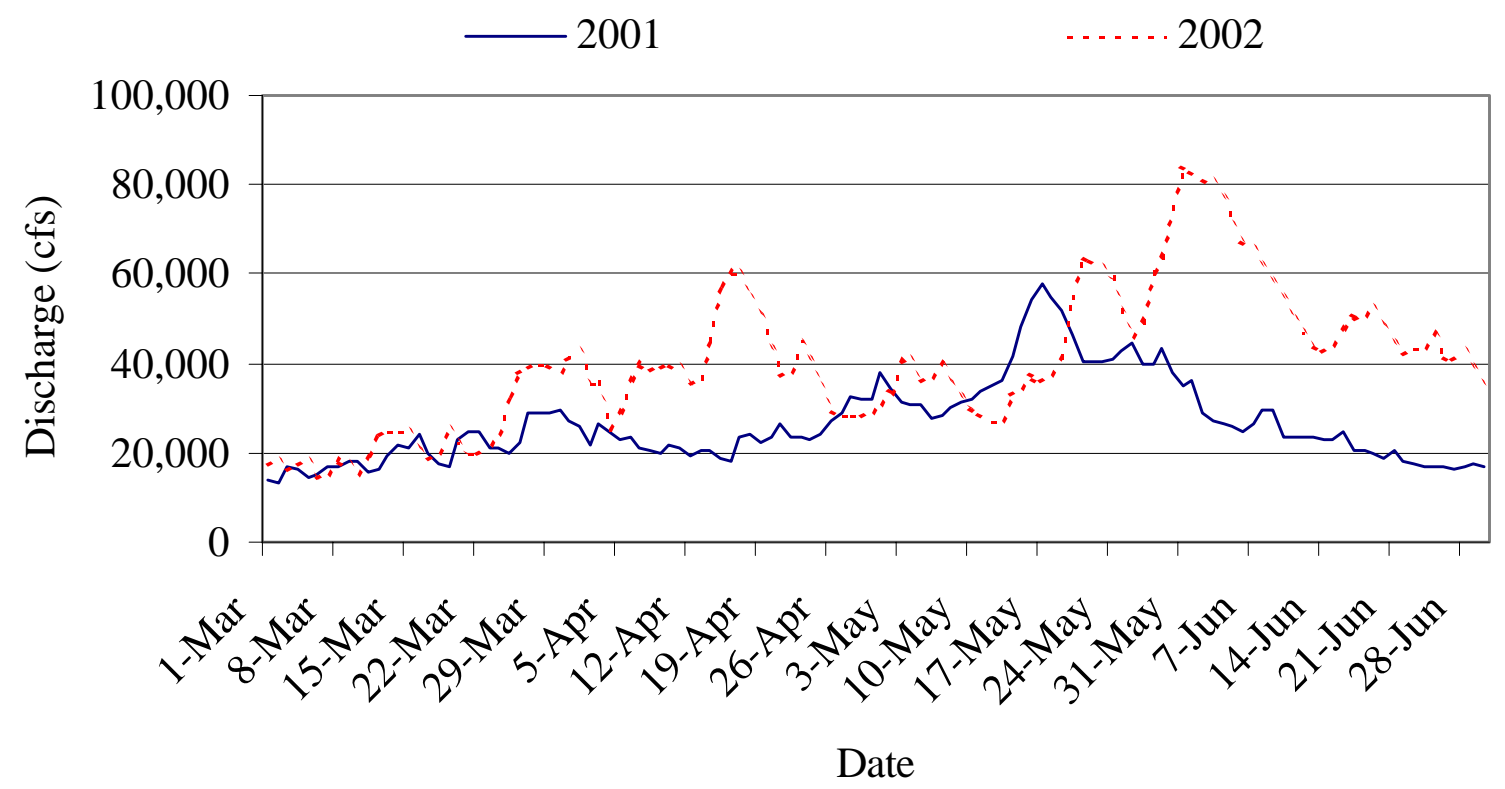

Figure 6. The average daily discharge for 2001 and 2002 from March 1 to June 30, for the Snake River USGS gauge 13334300.

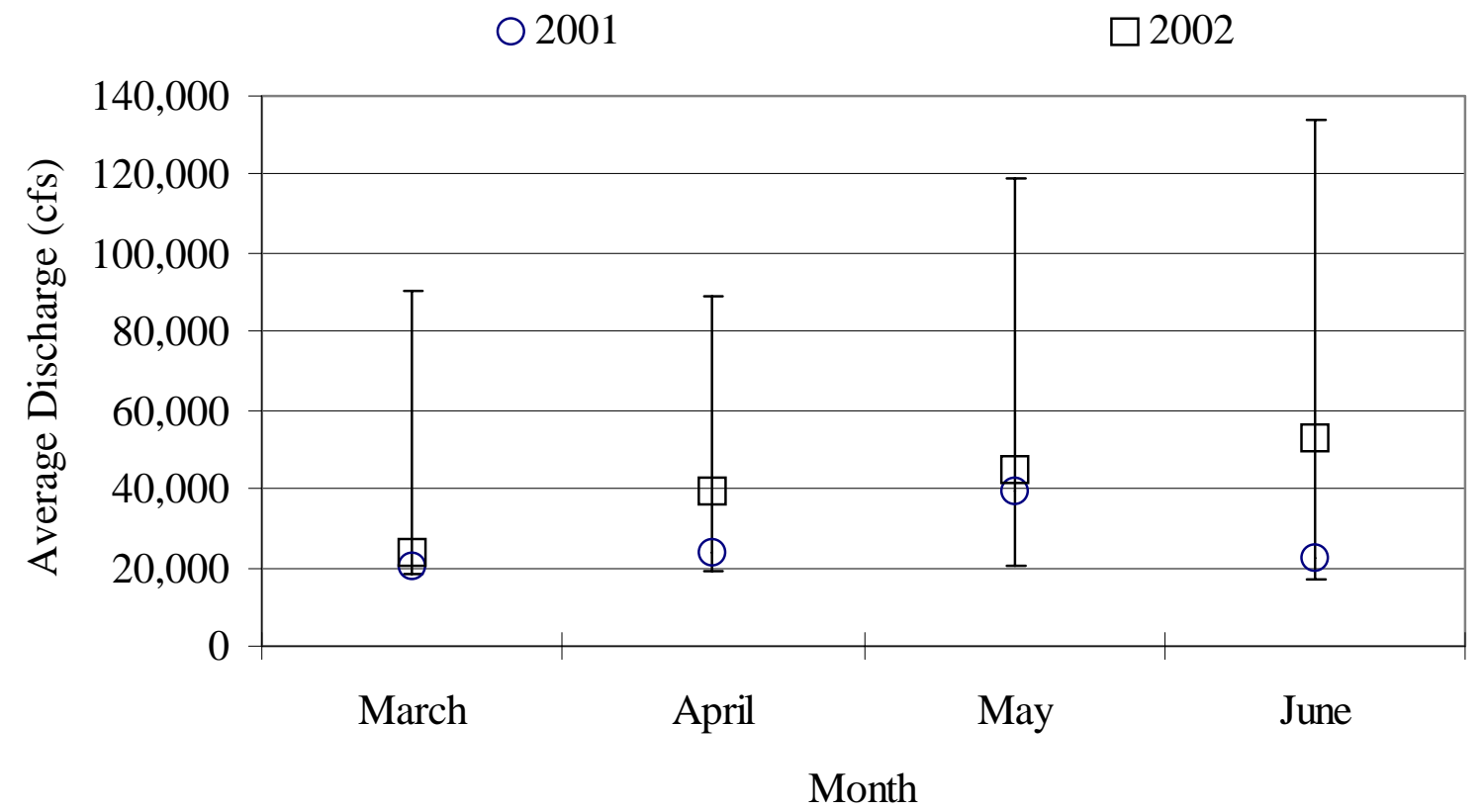

Figure 7. The average monthly discharge for the months of March, April, May, and June, for 2001 and 2002, at the Snake River USGS gauge 13334300. Bars indicate the minimum and maximum average monthly discharge values observed from 1959 to 2002 . 
$18,880 \mathrm{cfs}(534.6 \mathrm{cms})$ to $88,700 \mathrm{cfs}(2,511.7 \mathrm{cms})$ for April, 20,610 cfs $(583.6 \mathrm{cms})$ to 118,700 cfs $(3,361.2 \mathrm{cms})$ for May, and 16,850 cfs $(477.1 \mathrm{cms})$ to $134,200 \mathrm{cfs}(3,800.1 \mathrm{cms})$ for June. The average monthly discharge of $20,365 \mathrm{cfs}(576.7 \mathrm{cms}), 23,727 \mathrm{cfs}(671.9 \mathrm{cms}), 39,368 \mathrm{cfs}$ $(1,114.8 \mathrm{cms})$, and 22,413 cfs $(634.7 \mathrm{cms})$ for the months of March, April, May, and June of 2001, respectively, were near the bottom of the 1959 to 2002 range of average monthly discharge values (Figure 7).

The minimum discharge for the spring of 2002 was 14,599 cfs (413.4 cms) and occurred on March 6. The maximum discharge for the spring of 2002 was 84,200 cfs $(2,384.3 \mathrm{cms})$ and occurred on May 31. As observed in 2001, average monthly discharge of 24,019 cfs $(680.1 \mathrm{cms})$, $39,466 \mathrm{cfs}(1,117.6 \mathrm{cms}), 44,881 \mathrm{cfs}(1,270.9 \mathrm{cms})$, and 53,183 cfs $(1,506.0 \mathrm{cms})$ for the months of March, April, May, and June of 2001, respectively, were near the bottom of the 1959 to 2002 range of average monthly discharge values (Figure 7).

Snake River water temperatures from March 1 to June 21, 2001, ranged from $3.6^{\circ} \mathrm{C}$ on March 1 to $18.9{ }^{\circ} \mathrm{C}$ on June 21. The following spring the mean water temperature from March 2 to June 15 in the Snake River ranged from $3.1^{\circ} \mathrm{C}$ on March 2 to $16.0{ }^{\circ} \mathrm{C}$ on June 15.

A brief spill of less than $10 \mathrm{Kcfs}$ occurred at LGR from August 27 to August 30, 2001 (Figure 8). BPA declared a power emergency from April 3 to April 13, 2001 which resulted in the elimination of spill for fish passage (Anonymous 2001). LGO spilled $1.5 \mathrm{Kcfs}$ on June 21. LMO spilled 2.9 to $3.3 \mathrm{Kcfs}$ daily from August 20 to August 22. The largest spill occurred at MCN from May 25 to June 15 where 7.2 to $7.6 \mathrm{Kcfs}$ was spilled daily.

As outflow decreased at LGR, LGO, LMO, and MCN during 2001, water temperatures increased. Maximum water temperatures in the tailraces of the dams were as follows: $20.8^{\circ} \mathrm{C}$ on July 8 at LGR, $20.9{ }^{\circ} \mathrm{C}$ on July 12 at LGO, $21.1{ }^{\circ} \mathrm{C}$ on July 17 at LMO, and $21.9{ }^{\circ} \mathrm{C}$ at MCN on August 16. The upper lethal limit for any species of salmon occurs at $25.1^{\circ} \mathrm{C}$ (Brett 1952 , as cited in Groot et al. 1995).

Continuous spill at LGR for migration year 2002 began on April 3 and lasted until July 4 (Figure 9). Spill resumed on July 9 for five days and again on July 15 for two days. LGR spilled an additional three days in August and September with spills of $2.2 \mathrm{Kcfs}$ or less daily. At LGO spill occurred from April 5 to June 21, June 27 to July 4, July 9 to July 13, July 15 to July 16, and from August 19 to August 22. Spill at LMO occurred on eight days: April 15 to April 16, and May 30 to June 4. McNary Dam spilled from April 10 to August 2. As observed in 2001, water temperatures in the tailrace of each dam increased in late July with the following maximum water temperatures observed: $19.9^{\circ} \mathrm{C}$ on July 21 at LGR, $20.9{ }^{\circ} \mathrm{C}$ on July 29 at LGO, $21.2^{\circ} \mathrm{C}$ on August 1 at LMO, and $20.9^{\circ} \mathrm{C}$ on August 29 at MCN. 


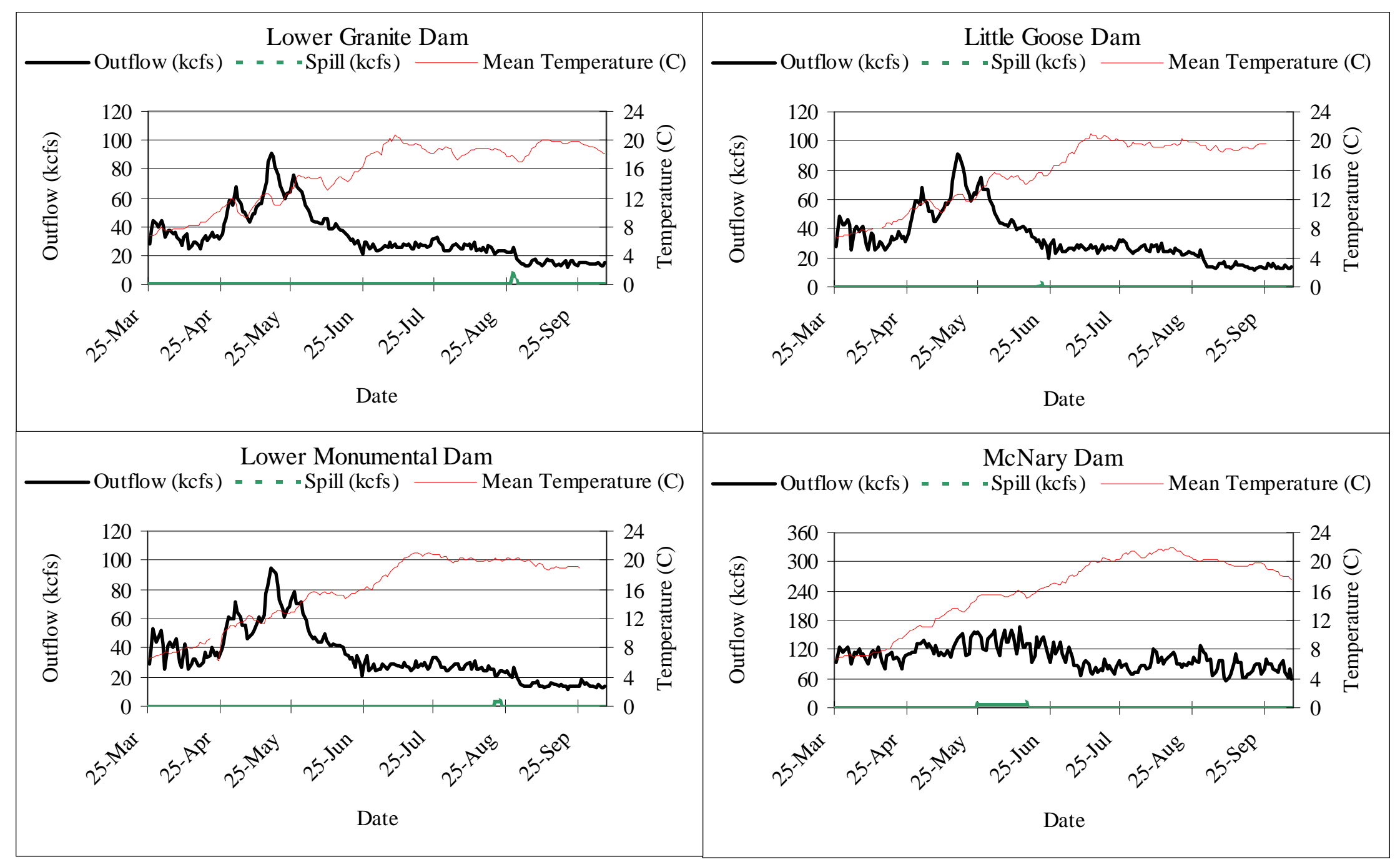

Figure 8. Measurements of outflow, spill, and mean temperature at Lower Granite Dam (top left), Little Goose Dam (top right), Lower Monumental Dam (lower left) and McNary Dam (lower right), from April 2 to September 2, 2001. Data was obtained on line at http://www.cqs.washington.edu/dart . 


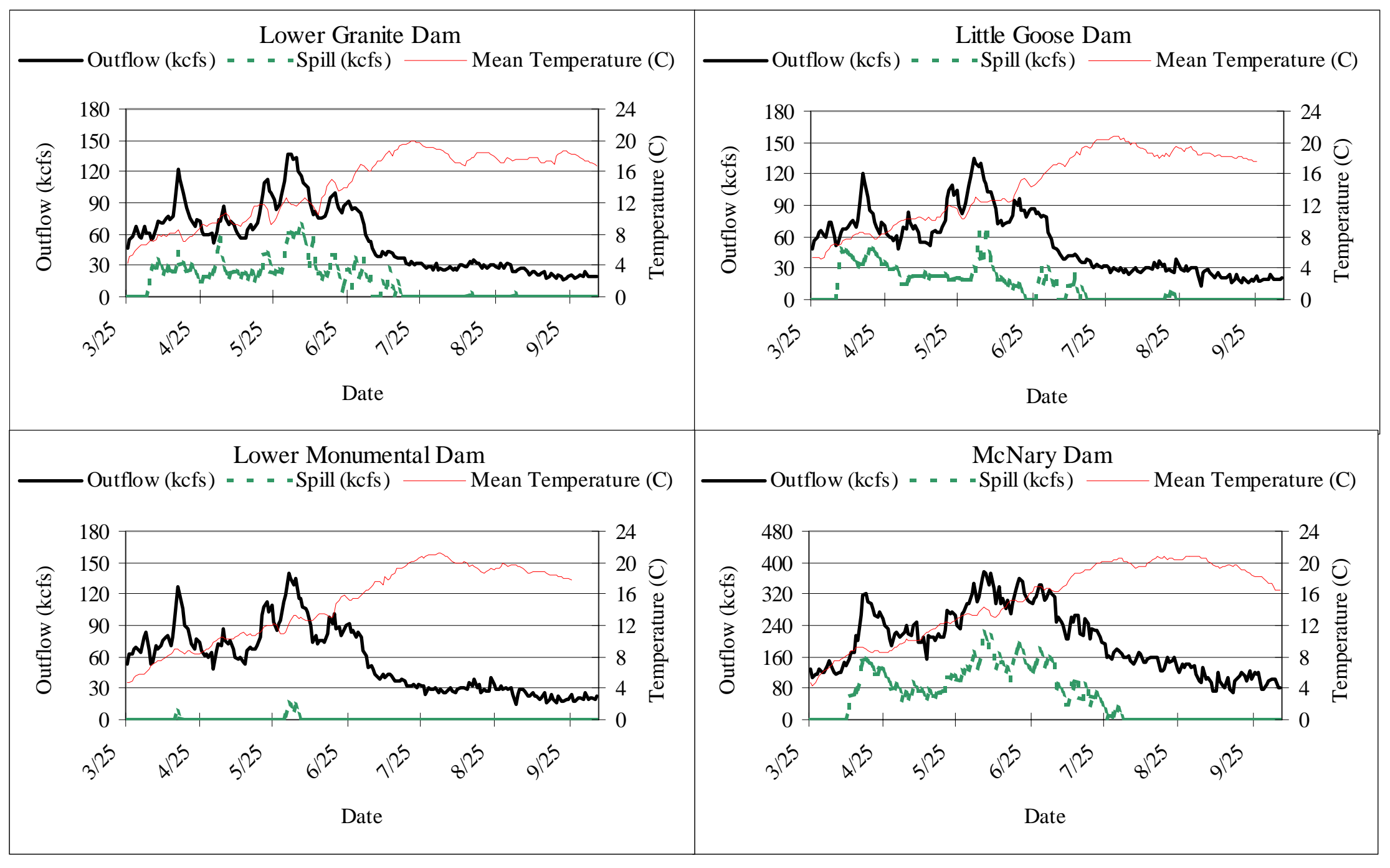

Figure 9. Measurements of outflow, spill, and mean temperature at Lower Granite Dam (top left), Little Goose Dam (top right), Lower Monumental Dam (lower left) and McNary Dam (lower right), from April 2 to September 2, 2002. Data was obtained on line at http://www.cqs.washington.edu/dart . 


\section{Hatchery Releases}

\section{$\underline{\text { Hatchery Chinook Salmon Releases }}$}

A total of 123,014 hatchery chinook salmon were released into the Imnaha River in 2001 (Table 1). Fish were allowed to leave the acclimation facility volitionally from March 21 to April 19 after being acclimated for 19 to 20 days. Fish that remained in the acclimation facility on April 19 were forced out. All hatchery chinook salmon in 2001 were marked with adipose fin clips and coded wire tags. An additional 20,922 fish were PIT tagged prior to acclimation and release. A total of 303,769 hatchery chinook salmon were volitionally released for the 2002 migration year. The volitional release occurred from March 21 to April 17, 2002. They were acclimated for 16 to 20 days. Any fish remaining in the pond on April 17 were forced out. As in 2001, all hatchery chinook salmon were marked with adipose fin clips and coded wire tags and an additional 20,920 were PIT tagged (Oregon Dept. of Fish and Wildlife 2002a and 2002b, and Eddy 2002).

\section{$\underline{\text { Hatchery Steelhead Releases }}$}

A total of 342,622 hatchery steelhead smolts were released in 2001. Acclimated smolts $(159,159)$ were forced from the steelhead acclimation facility on April 11 and April 12, 2001. A total of 25,282 were marked with an adipose left ventral fin clip, 53,794 were marked with a coded wire tag, and 494 were marked with a PIT tag and adipose fin clip. The remainder had an adipose fin clip. They were acclimated for 34 to 38 days. A second group of 100,166 steelhead smolts were direct stream released into Big Sheep Creek from April 17 to April 20 from the Irrigon Fish Hatchery. The second release included 40,287 steelhead marked only with visual implant tags and 59,879 marked only with an adipose fin clip. A third release of 83,297 acclimated steelhead into Little Sheep Creek occurred from May 9 and 10. The third release of steelhead during the 2001 migration year was marked with 22,646 adipose left ventral fin clips, 253 PIT tagged fish with adipose fin clips, and the remainder was marked with adipose fin clips. They were acclimated for 19 to 24 days.

During the 2002 migration year a total of 305,000 steehead were released into the Imnaha subbasin. The first release of hatchery steelhead occurred on April 11 and April 12 and totaled 128,500 hatchery steelhead with 25,000 adipose left ventral fin clips and a coded wire tag, 50,000 with a blank coded wire tag, and 53,500 with adipose fin clips. Hatchery steelhead released on April 11 and 12 were acclimated for 34 to 39 days. Hatchery steelhead $(n=100,000)$ were transported from Irrigon Fish Hatchery for a direct stream release into Big Sheep Creek on April 17 and April 18. The Irrigon steelhead were not marked. The final release occurred May 9 and May 10 from the steelhead acclimation facility. A total of 76,500 steelhead with 25,000 adipose left ventral fin clips and coded wire tags, and 51,500 adipose fin clips were released into Little Sheep Creek after an acclimation period of 20 to 32 days (Oregon Dept. of Fish and Wildlife 2002a and 2002b, and Eddy 2002). 
Table 1. Releases of hatchery reared chinook salmon and steelhead smolts in the Imnaha River Subbasin during migration years 2001 and 2002 (Oregon Dept. of Fish and Wildlife 2002a and Oregon Dept. of Fish and Wildlife 2002b).

\begin{tabular}{|c|c|c|c|c|c|c|}
\hline$\overline{\text { Year }}$ & Species & Dates Ponded & Numbers & Release Dates & Tags/Marks & Release Site \\
\hline 2001 & Chinook Salmon & March 1 and 2 & 123,014 & Mar. 21 to Apr.19 & $\begin{array}{l}\text { 100\% Adipose Fin Clipped and Coded Wire } \\
\text { Tagged, with 20,922 PIT tags }\end{array}$ & Imnaha River \\
\hline 2002 & Chinook Salmon & March 1,4 , and 5 & 303,769 & Mar. 21 to Apr. 17 & $\begin{array}{l}\text { 100\% Adipose Fin Clipped and Coded Wire } \\
\text { Tagged, with 20,920 PIT tags }\end{array}$ & Imnaha River \\
\hline 2001 & Steelhead & March 5, 6, 7, and 8 & 159,159 & Apr. 11 to Apr. 12 & $\begin{array}{l}\text { 25,282 with Adipose Left Ventral Clips, } \\
53,794 \text { with only Coded Wire Tags, } 494 \text { PIT } \\
\text { tags and Adipose Fin Clips, and 79,589 with } \\
\text { only Adipose Fin Clips }\end{array}$ & Little Sheep Creek \\
\hline 2001 & Steelhead & NA (direct stream release) & 100,166 & Apr. 17 to Apr. 20 & $\begin{array}{l}\text { 40,287 VIE tags without Adipose Fin Clips, } \\
\text { 59,879 with Adipose Fin Clips }\end{array}$ & Big Sheep Creek \\
\hline 2001 & Steelhead & April $16,17,18,19$, and 20 & 83,297 & May 9 to May 10 & $\begin{array}{l}\text { 22,646 Adipose Left Ventral Fin Clips, } \\
253 \text { PIT tags, 60,398 Adipose Fin Clips }\end{array}$ & Little Sheep Creek \\
\hline 2002 & Steelhead & March 4 and 8 & 128,500 & Apr. 11 to Apr. 12 & $\begin{array}{l}\text { 25,000 with Adipose Left Vental Fin Clips } \\
\text { and Coded Wire Tags, 50,000 with Blank } \\
\text { Coded Wire Tags, and 53,500 with Adipose } \\
\text { Clip only }\end{array}$ & Little Sheep Creek \\
\hline 2002 & Steelhead & NA (direct stream release) & 100,000 & Apr. 17 to Apr. 18 & (no marks) & Big Sheep Creek \\
\hline 2002 & Steelhead & April 18 and 19 & 76,500 & May 9 to May 10 & $\begin{array}{l}\text { 25,000 with Adipose Left Vental Fin Clips } \\
\text { and Coded Wire Tags, 51,500 with Adipose } \\
\text { Fin Clips }\end{array}$ & Little Sheep Creek \\
\hline
\end{tabular}




\section{Juvenile Chinook Salmon and Steelhead Catch}

\section{$\underline{\text { Catch for Migration Year } 2001}$}

We captured at total of 2,318 natural chinook salmon pre-smolts and 63 natural steelhead at the upper trap from October 17 to November 9, 2000 (Table 2, Appendix Table C1). The largest weekly catch of natural chinook salmon occurred during the week of October 22. Natural chinook salmon pre-smolts $(\mathrm{n}=2,981)$ and natural steelhead $(\mathrm{n}=360)$ were captured at the lower trap from October 17 to November 15, 2000 (Appendix Table C1). The largest weekly catch $(\mathrm{n}=1,398)$ occurred during the week of October 29 and the smallest weekly catch $(\mathrm{n}=$ 343) occurred during the week of November 12. Average weekly discharge ranged from $141 \mathrm{cfs}$ during the week of November 11 to $193 \mathrm{cfs}$ during the week of November 29 and average water temperature ranged from $1.4{ }^{\circ} \mathrm{C}$ during the week of November 12 to $11.1^{\circ} \mathrm{C}$ during the week of October 15 .

The majority of the chinook salmon that we captured during the spring of 2001 were smolts. Chinook salmon less than $65 \mathrm{~mm}$ were reported to the FPC as age 0 chinook salmon. A total of 10,663 natural chinook salmon, 16,097 hatchery chinook salmon, 6,462 natural steelhead, and 28,451 hatchery steelhead were captured in the lower trap from February 22 to June 21, 2001 (Table 2, Appendix C2). Low discharge during the month of March may have increased the efficiency of the lower trap and allowed a second trap to be fished from March 16 to March 24. When weekly discharge reached a mean of $281 \mathrm{cfs}$ and water temperatures reached a mean of 8.4 ${ }^{\circ} \mathrm{C}$ during the week of March 18, the catch increased to 3,661 natural chinook salmon. Weekly catches of more than 1,000 natural chinook salmon occurred during the weeks of March 18, 25 and April 15. Hatchery chinook salmon were first captured during the week of March 18 and more than 1,000 hatchery chinook salmon were captured from the week of March 25 to the week of April 22. The largest catch of hatchery chinook salmon $(n=6,351)$ occurred during the week of April 15 when the average weekly discharge was $418 \mathrm{cfs}$ and the average weekly temperature was $9.3{ }^{\circ} \mathrm{C}$. Hatchery chinook salmon were forced from the acclimation facility during the week of April 15, on April 19.

Natural steelhead were captured from the week of February 25 to the week of June 17 and weekly catches of more than 1,000 natural steelhead occurred from the week of April 22 to the week of May 13 when the average weekly discharge ranged from $637 \mathrm{cfs}$ (April 22) to 902 cfs during the week of May 13. The largest weekly catch of natural steelhead occurred during the week of May 6 when 1,451 natural steelhead were captured during weekly discharge of $657 \mathrm{cfs}$ and weekly average temperature of $11.3{ }^{\circ} \mathrm{C}$. More than 1,000 hatchery steelhead were captured weekly from the week of April 15 to the week of May 27. These large weekly catches of hatchery steelhead resulted from the weekly releases of hatchery steelhead in Big Sheep Creek and Little Sheep Creek. The largest weekly catch $(n=11,718)$ occurred during the week of May 13 and coincided with the release on May 10 at Little Sheep Creek and the highest average weekly spring flow (902 cfs) observed for the Imnaha River in 2001. 
Table 2. The weekly mean discharge (cfs), temperature (C) and catch of natural and hatchery chinook salmon and steelhead at the upper and lower Imnaha River from October 17 to November 15, 2000, and February 22 to June 21, 2001.

\begin{tabular}{|c|c|c|c|c|c|c|}
\hline $\begin{array}{c}\text { Trap } \\
\text { and } \\
\text { Week } \\
\end{array}$ & $\begin{array}{c}\text { Average } \\
\text { Discharge } \\
(\mathrm{cfs}) \\
\end{array}$ & $\begin{array}{c}\text { Average } \\
\text { Temperature } \\
\text { (C) } \\
\end{array}$ & $\begin{array}{c}\text { Natural } \\
\text { Chinook } \\
\text { Salmon } \\
\end{array}$ & $\begin{array}{c}\text { Hatchery } \\
\text { Chinook } \\
\text { Salmon } \\
\end{array}$ & $\begin{array}{c}\text { Natural } \\
\text { Steelhead }\end{array}$ & $\begin{array}{l}\text { Hatchery } \\
\text { Steelhead }\end{array}$ \\
\hline \multicolumn{7}{|c|}{ Upper Trap - Fall of 2000} \\
\hline $10 / 15$ & & & 203 & & 4 & \\
\hline $10 / 22$ & & & 1,181 & & 21 & \\
\hline $10 / 29$ & & & 568 & & 33 & \\
\hline $11 / 5$ & & & 366 & & 5 & \\
\hline \multicolumn{7}{|c|}{ Lower Trap - Fall of 2000} \\
\hline $10 / 15$ & 158 & 11.1 & 117 & & 43 & \\
\hline $10 / 22$ & 166 & 7.7 & 896 & & 88 & \\
\hline $10 / 29$ & 193 & 7.0 & 1,398 & & 117 & \\
\hline $11 / 5$ & 165 & 4.6 & 227 & & 62 & \\
\hline $11 / 12$ & 141 & 1.4 & 343 & & 50 & \\
\hline \multicolumn{7}{|c|}{ Lower Trap - Spring of 2001} \\
\hline $2 / 18$ & 134 & 5.1 & 6 & & & \\
\hline $2 / 25$ & 131 & 3.4 & 17 & & 2 & \\
\hline $3 / 4$ & 165 & 6.5 & 11 & & 1 & \\
\hline $3 / 11$ & 191 & 6.5 & 417 & & 4 & \\
\hline $3 / 18$ & 281 & 8.4 & 3,661 & 117 & 82 & \\
\hline $3 / 25$ & 359 & 7.9 & 1,790 & 1,608 & 76 & 5 \\
\hline $4 / 1$ & 305 & 7.3 & 864 & 4,744 & 27 & 1 \\
\hline $4 / 8$ & 289 & 7.0 & 600 & 1,085 & 47 & 29 \\
\hline $4 / 15$ & 418 & 9.3 & 1,318 & 6,351 & 645 & 2,051 \\
\hline $4 / 22$ & 637 & 10.9 & 877 & 1,682 & 1,253 & 2,491 \\
\hline $4 / 29$ & 721 & 8.9 & 327 & 297 & 1,039 & 2,952 \\
\hline $5 / 6$ & 657 & 11.3 & 299 & 192 & 1,451 & 5,521 \\
\hline $5 / 13$ & 902 & 10.7 & 126 & 13 & 1,319 & 11,718 \\
\hline $5 / 20$ & 758 & 14.5 & 144 & 8 & 357 & 1,363 \\
\hline $5 / 27$ & 692 & 14.8 & 53 & & 107 & 1,797 \\
\hline $6 / 3$ & 437 & 13.4 & 52 & & 37 & 300 \\
\hline $6 / 10$ & 385 & 14.1 & 78 & & 14 & 178 \\
\hline $6 / 17$ & 319 & 17.2 & 23 & & 1 & 45 \\
\hline
\end{tabular}




\section{Catch for Migration Year 2002}

Fall trapping from October 18 to November 27, 2001, resulted in a catch of 1,415 natural chinook salmon pre-smolts and 46 natural steelhead at the upper trap (Table 3, Appendix Table C3). The largest weekly catch of natural chinook salmon pre-smolts $(n=405)$ at the upper trap occurred during the week of October 21. At the lower trap, 2,149 natural chinook salmon presmolts and 948 natural steelhead were captured from October 17 to November 8 . The largest weekly catch of natural chinook salmon pre-smolts $(n=835)$ occurred during the week of October 21 when the average weekly discharge was $130 \mathrm{cfs}$ and average weekly temperatures were $8.4{ }^{\circ} \mathrm{C}$.

A total of 2,693 natural chinook salmon, 26,407 hatchery chinook salmon, 6,956 natural steelhead, and 25,086 hatchery steelhead were captured at the lower trap during the spring of 2002 (Table 3, Appendix Table C4). The largest weekly catch of natural chinook salmon during the spring of 2002 occurred during the week of March 24 when 528 fish were captured. The average weekly discharge was $417 \mathrm{cfs}$ and the average weekly temperature was $6.9{ }^{\circ} \mathrm{C}$. The largest catch of hatchery chinook salmon also occurred during the week of March 24 when 13,174 fish were caught. Weekly catches of more than 1,000 hatchery chinook salmon continued to the week of April 14.

Only one weekly catch of more than 1,000 natural steelhead occurred, during the week of May 12 when average weekly discharge was $938 \mathrm{cfs}$ and average weekly temperature was 10.1 ${ }^{\circ} \mathrm{C}$. The week of May 12 was also the week when the largest catch of hatchery steelhead $(\mathrm{n}=$ $8,286)$ occurred. This catch coincided with a release from the Little Sheep Creek Acclimation Facility on May 10. Weekly catches of more than 1,000 hatchery steelhead occurred from the week of April 14 to the week of May 26. Due to the forced and direct release strategies for hatchery steelhead, weekly catches are more related to release timing as presented in Table 1 than they are related to the river discharge and temperature presented in Appendices A and B.

\section{PIT Tagging for Migration Year 2001}

A total of 13,872 Imnaha River natural chinook salmon were PIT tagged for migration year 2001 (Table 4). Natural chinook salmon tagged for migration year 2001 consisted of three groups: 1,858 natural chinook salmon pre-smolts tagged at the upper trap during the fall of 2000, 2,009 natural chinook salmon pre-smolts tagged at the lower trap during the fall of 2000, and 10,005 natural chinook salmon smolts tagged at the lower trap during the spring of 2001. Weekly PIT tag release groups at the upper trap ranged from 199 fish during the week of October 15 to 801 fish during the week of October 22. PIT tag release groups at the lower trap ranged from 114 fish during the week of October 15 to 883 fish during the week of October 22. No limit was set for weekly PIT tag release groups of natural chinook salmon during the spring of 2001 because sampling was designed to provide for future estimates of smolt to adult returns and the initial sample size estimated by LSRCP required 12,000 natural chinook salmon. Weekly release groups ranged from four fish during the week of February 18 to 3,462 fish during the week of 
Table 3. The weekly mean discharge (cfs), temperature (C) and catch of natural and hatchery chinook salmon and steelhead at the upper and lower Imnaha River from October 17 to November 27, 2001, and March 4 to June 12, 2002.

\begin{tabular}{|c|c|c|c|c|c|c|}
\hline $\begin{array}{c}\text { Trap } \\
\text { and } \\
\text { Week }\end{array}$ & $\begin{array}{l}\text { Average } \\
\text { Discharge } \\
\text { (cfs) }\end{array}$ & $\begin{array}{c}\text { Average } \\
\text { Temperature } \\
\text { (C) }\end{array}$ & $\begin{array}{l}\text { Natural } \\
\text { Chinook } \\
\text { Salmon }\end{array}$ & $\begin{array}{l}\text { Hatchery } \\
\text { Chinook } \\
\text { Salmon }\end{array}$ & $\begin{array}{c}\text { Natural } \\
\text { Steelhead }\end{array}$ & $\begin{array}{l}\text { Hatchery } \\
\text { Steelhead }\end{array}$ \\
\hline \multicolumn{7}{|c|}{ Upper Trap - Fall of 2001} \\
\hline $10 / 14$ & & & 137 & & 2 & \\
\hline $10 / 21$ & & & 405 & & 4 & \\
\hline $10 / 28$ & & & 338 & & 31 & \\
\hline $11 / 4$ & & & 293 & & & \\
\hline $11 / 11$ & & & 91 & & & \\
\hline $11 / 18$ & & & 129 & & 7 & \\
\hline $11 / 25$ & & & 22 & & 2 & \\
\hline \multicolumn{7}{|c|}{ Lower Trap - Fall of 2001} \\
\hline $10 / 14$ & 118 & 10.3 & 153 & & 66 & 1 \\
\hline $10 / 21$ & 130 & 8.4 & 835 & & 319 & \\
\hline $10 / 28$ & 169 & 9.1 & 557 & & 448 & \\
\hline $11 / 4$ & 123 & 5.7 & 604 & & 115 & 1 \\
\hline \multicolumn{7}{|c|}{ Lower Trap - Spring of 2002} \\
\hline $3 / 3$ & 157 & 3.3 & 11 & 7 & 9 & \\
\hline $3 / 10$ & 167 & 5.5 & 18 & 9 & 14 & \\
\hline $3 / 17$ & 201 & 5.3 & 19 & 143 & 2 & \\
\hline $3 / 24$ & 417 & 6.9 & 528 & 13,174 & 74 & 1 \\
\hline $3 / 31$ & 697 & 8.2 & 285 & 7,201 & 48 & \\
\hline $4 / 7$ & 1,042 & 8.4 & 257 & 1,968 & 77 & 139 \\
\hline $4 / 14$ & 1,325 & 7.0 & 384 & 2,375 & 190 & 2,824 \\
\hline $4 / 21$ & 875 & 8.2 & 442 & 842 & 303 & 2,493 \\
\hline $4 / 28$ & 1,243 & 8.9 & 452 & 564 & 776 & 1,656 \\
\hline $5 / 5$ & 1,037 & 7.3 & 60 & 64 & 653 & 4,918 \\
\hline $5 / 12$ & 938 & 10.1 & 173 & 49 & 3,323 & 8,286 \\
\hline $5 / 19$ & 1,110 & 8.9 & 31 & 11 & 839 & 2,932 \\
\hline $5 / 26$ & 1,585 & 11.1 & 11 & & 357 & 1,359 \\
\hline $6 / 2$ & 1,417 & 10.6 & 12 & & 235 & 325 \\
\hline $6 / 9$ & 962 & 11.6 & 10 & & 56 & 153 \\
\hline
\end{tabular}


Table 4. Weekly numbers of PIT tagged fish released from the upper and lower Imnaha River screw traps, October 17 to November 15, 2000, and February 22 to June 21, 2001.

\begin{tabular}{|c|c|c|c|c|c|}
\hline $\begin{array}{c}\text { Week } \\
\text { Released }\end{array}$ & $\begin{array}{c}\text { Natural Chinook } \\
\text { Salmon } \\
\end{array}$ & $\begin{array}{c}\text { Hatchery Chinook } \\
\text { Salmon }\end{array}$ & $\begin{array}{c}\text { Natural } \\
\text { Steelhead } \\
\end{array}$ & $\begin{array}{l}\text { Hatchery } \\
\text { Steelhead } \\
\end{array}$ & $\begin{array}{c}\text { Weekly } \\
\text { Total }\end{array}$ \\
\hline \multicolumn{6}{|c|}{ Upper Trap - Fall of 2000} \\
\hline 15-Oct & 199 & & 1 & & 200 \\
\hline 22-Oct & 801 & & & & 801 \\
\hline 29-Oct & 501 & & & & 501 \\
\hline $5-\mathrm{Nov}$ & 357 & & & & 357 \\
\hline \multicolumn{6}{|c|}{ Lower Trap - Fall of 2000} \\
\hline $15-\mathrm{Oct}$ & 114 & & & & 114 \\
\hline 22-Oct & 883 & & & & 883 \\
\hline 29-Oct & 499 & & 1 & & 500 \\
\hline 5-Nov & 209 & & & & 209 \\
\hline 12-Nov & 304 & & & & 304 \\
\hline \multicolumn{6}{|c|}{ Lower Trap - Spring of 2001} \\
\hline $18-\mathrm{Feb}$ & 4 & & & & 4 \\
\hline $25-\mathrm{Feb}$ & 13 & & & & 13 \\
\hline 4-Mar & 25 & & 1 & & 26 \\
\hline 11-Mar & 403 & & 1 & & 404 \\
\hline 18-Mar & 3,462 & 98 & 78 & & 3,638 \\
\hline 25-Mar & 1,755 & 602 & 77 & 2 & 2,436 \\
\hline 1-Apr & 818 & 1,147 & 27 & & 1,992 \\
\hline 8-Apr & 580 & 297 & 46 & 4 & 927 \\
\hline 15-Apr & 1,166 & 493 & 451 & 160 & 2,270 \\
\hline 22-Apr & 816 & 369 & 438 & 610 & 2,233 \\
\hline 29-Apr & 313 & & 710 & 602 & 1,625 \\
\hline 6-May & 254 & 2 & 1,318 & 1,313 & 2,887 \\
\hline 13-May & 67 & & 332 & 500 & 899 \\
\hline 20-May & 140 & & 200 & 272 & 612 \\
\hline 27-May & 49 & & & & 49 \\
\hline 3-Jun & 50 & & & & 50 \\
\hline 10-Jun & 78 & & & & 78 \\
\hline 17-Jun & 12 & & & & 12 \\
\hline Total & 13,872 & 3,008 & 3,681 & 3,463 & 24,024 \\
\hline
\end{tabular}


March 18.

A total of 3,008 hatchery chinook salmon were PIT tagged for the 2001 migration year. Weekly PIT tag release groups of hatchery chinook salmon ranged from two fish during the week of May 6 to 1,147 fish during the week of April 1. The tagging goal was 600 hatchery chinook salmon for a five week period, but that goal was modified to attempt to accurately represent the catch of hatchery chinook at the Imnaha River trap.

The total number of spring tagged natural steelhead released for the 2001 migration year totaled 3,681 fish. Weekly PIT tag release groups of natural steelhead during the spring of 2001 ranged from one fish during the weeks of March 4 and March 11 to 1,318 fish during the week of May 6. PIT tagged hatchery steelhead totaled 3,463 fish for the 2001 migration year. Weekly PIT tag release groups of hatchery steelhead ranged in size from two fish during the week of March 25 to 1,313 fish during the week of May 6.

\section{PIT Tagging for Migration Year 2002}

A total of 1,217 natural chinook salmon pre-smolts were PIT tagged at the upper trap during the fall of 2001 for the 2002 migration year. Weekly release groups ranged from 21 fish during the week of November 25 to 333 fish during the week of October 21 (Table 5). PIT tagging at the lower trap during the fall of 2001 resulted in an annual release group of 2,011 natural chinook salmon pre-smolts. The range in weekly release groups varied from 153 fish during the week of October 14 to 818 fish during the week of October 21. A third group of 2,321 natural chinook salmon were PIT tagged and released during the spring in weekly release groups ranging from seven fish during the week of June 9 to 436 fish during the week of April 28. These three release groups of natural chinook salmon totaled 5,549 fish.

A total of 3,022 hatchery chinook salmon were PIT tagged and released for the 2002 migration year. Weekly release groups of hatchery chinook salmon ranged from one fish during the week of May 19 to 531 fish during the week of April 14.

The total number of PIT tagged natural steelhead released for the 2002 migration year was 4,809 fish. Natural steelhead were tagged during the spring in weekly releases groups ranging from one fish during the week of March 3 to 1,960 fish during the week of May 12. A total of 2,153 hatchery steelhead were released for the 2002 migration year. Hatchery steelhead weekly PIT tag release groups ranged from one fish during the week of June 2 to 309 fish during the week of April 28. Release groups from the week of April 14 to the week of May 19 were more consistent; ranging in size from 300 to 309 fish.

\section{$\underline{\text { Recaptures of Previously PIT Tagged Fish }}$}

During the fall of 2000, 65 previously PIT tagged natural chinook salmon were recaptured in the lower trap (Appendix Table C5). Fifty-seven of these fish were tagged by NPT 
Table 5. Weekly numbers of PIT tagged fish released from the upper and lower Imnaha River screw traps, October 17 to November 27, 2001, and March 4 to June 12, 2002.

\begin{tabular}{|c|c|c|c|c|c|}
\hline $\begin{array}{c}\text { Week } \\
\text { Released }\end{array}$ & $\begin{array}{c}\text { Natural Chinook } \\
\text { Salmon }\end{array}$ & $\begin{array}{l}\text { Hatchery Chinook } \\
\text { Salmon }\end{array}$ & $\begin{array}{c}\text { Natural } \\
\text { Steelhead }\end{array}$ & $\begin{array}{l}\text { Hatchery } \\
\text { Steelhead }\end{array}$ & $\begin{array}{c}\text { Weekly } \\
\text { Total }\end{array}$ \\
\hline \multicolumn{6}{|c|}{ Upper Trap - Fall of 2001} \\
\hline $14-\mathrm{Oct}$ & 116 & & & & 116 \\
\hline $21-$ Oct & 333 & & & & 333 \\
\hline $28-O c t$ & 263 & & & & 263 \\
\hline 4-Nov & 279 & & & & 279 \\
\hline 11-Nov & 84 & & & & 84 \\
\hline 18-Nov & 121 & & & & 121 \\
\hline 25-Nov & 21 & & & & 21 \\
\hline \multicolumn{6}{|c|}{ Lower Trap - Fall of 2001} \\
\hline $14-O c t$ & 153 & & 1 & & 154 \\
\hline $21-$ Oct & 818 & & & & 818 \\
\hline 28-Oct & 584 & & & & 584 \\
\hline 4-Nov & 456 & & & & 456 \\
\hline \multicolumn{6}{|c|}{ Lower Trap - Spring of 2002} \\
\hline 3-Mar & 9 & 6 & 1 & & 16 \\
\hline 10-Mar & 18 & 8 & 14 & & 40 \\
\hline 17-Mar & 19 & 115 & 2 & & 136 \\
\hline 24-Mar & 397 & 470 & 31 & & 898 \\
\hline 31-Mar & 175 & 500 & 45 & & 720 \\
\hline 7-Apr & 252 & 473 & 75 & 137 & 937 \\
\hline 14-Apr & 374 & 531 & 188 & 300 & 1,393 \\
\hline 21-Apr & 428 & 430 & 299 & 305 & 1,462 \\
\hline 28-Apr & 436 & 392 & 771 & 309 & 1,908 \\
\hline 5-May & 59 & 57 & 645 & 302 & 1,063 \\
\hline 12-May & 112 & 39 & 1,960 & 300 & 2,411 \\
\hline 19-May & 13 & 1 & 173 & 303 & 490 \\
\hline 26-May & 10 & & 308 & 196 & 514 \\
\hline 2-Jun & 12 & & 231 & 1 & 244 \\
\hline 9-Jun & 7 & & 65 & & 72 \\
\hline$\overline{\text { Total }}$ & 5,549 & 3,022 & 4,809 & 2,153 & 15,533 \\
\hline
\end{tabular}


at the upper trap during the fall of 2000. The other eight were tagged by ODFW in August of 2000. In the fall of 2001, six previously PIT tagged natural chinook salmon, all tagged by ODFW in August of 2001, were recaptured at the lower trap (Appendix Table C5).

Transceivers deployed at the lower Imnaha River trap during the spring of 2001 detected 2,526 hatchery chinook salmon, 134 natural chinook salmon, and 40 hatchery steelhead within a catch of 16,097 hatchery chinook salmon, 10,663 natural chinook salmon, and 28,451 hatchery steelhead, respectively, that had been previously PIT tagged. The number of these previously PIT tagged fish that were sampled for length, weight, and condition factors are shown in Table 6. The recaptured PIT tagged hatchery chinook salmon averaged $141 \mathrm{~mm}$ in fork length, $29.4 \mathrm{~g}$ in weight, and had an average condition factor of 1.05. Recaptured PIT tagged natural chinook salmon averaged $108 \mathrm{~mm}$ in fork length, $13.1 \mathrm{~g}$ in weight, and had an average condition factor of 1.04. The previously PIT tagged hatchery steelhead recaptured in the lower Imnaha River trap averaged $213 \mathrm{~mm}$ in fork length, $99.9 \mathrm{~g}$ in weight, and had an average condition factor of 0.97 (Table 6).

Fewer previously PIT tagged hatchery chinook salmon were recaptured during the spring of 2002 than in the spring of 2001. Out of a catch of 26,407 hatchery chinook salmon in 2002, 1,532 previously PIT tagged hatchery chinook salmon were detected. A total of 29 natural chinook salmon and 43 hatchery steelhead previously marked with PIT tags were detected within a catch of 2,693 natural chinook salmon and 25,086 hatchery steelhead. The number of these previously PIT tagged fish sampled for length, weight, and condition factors are shown in Table 7. The hatchery chinook salmon had an average fork length of $134 \mathrm{~mm}$, average weight of 27.2 $\mathrm{g}$, and an average condition factor of 1.09. Previously PIT tagged natural chinook salmon recaptured in 2002 averaged $101 \mathrm{~mm}$ in fork length, $11.4 \mathrm{~g}$, and had an average condition factor of 1.08. Hatchery steelhead averaged $202 \mathrm{~mm}$ in fork length, $82.9 \mathrm{~g}$, and had an average condition factor of 0.97 (Table 7).

The $90 \%$ arrival timing of previously PIT tagged hatchery chinook salmon at the lower trap occurred 34 days after the volitional release began in 2001(Figure 10). The following year $90 \%$ arrival at the lower trap for previously PIT tagged hatchery chinook salmon occurred 28 days after release. Lower than average monthly discharge in 2001 may have affected the travel time of hatchery chinook salmon between the acclimation facility and the lower trap.

The earliest 90\% arrival time presented in Figure 10 occurred in 1998. The release strategy in 1998 was an acclimated forced release. Ninety percent of all previously PIT tagged hatchery chinook salmon arrived 8 days after the release in 1998. The following year (1999) the majority of the hatchery chinook salmon $(n=184,567)$ were acclimated and released volitionally. A small number of hatchery chinook salmon in $1999(\mathrm{n}=10,242)$ were directly released into the Imnaha River (Cleary et al. 2003). A total of 1,007 previously PIT tagged hatchery chinook 
salmon from the acclimated volitional release group were recaptured at the lower trap. The 1999 acclimated volitional release group had a 90\% arrival time of 34 days. All hatchery chinook salmon in 2000 were acclimated and volitionally released. The 2000 hatchery chinook salmon arrival timing at the lower trap of 22 days was the earliest for an acclimated volitional release of hatchery chinook salmon from the Imnaha River.

The chinook salmon acclimation facility was designed as an adult holding pond. Water temperatures in the pond are not regulated from the source, the Imnaha River. Additionally, flow within the pond can be influenced by the Imnaha River (Patterson 2003). Annual variation in temperature and flow, in addition to fish size may influence migration timing and rate. Changes in the water level of the pond due to the build up and removal of ice may also influence the migration timing of hatchery chinook salmon during an acclimated volitional release.

Table 6. Averages, ranges, and standard deviations for fork lengths (mm), weights ( $\mathrm{g}$ ), and condition factors $(\mathrm{K})$ for PIT tag recaptures of hatchery chinook salmon, natural chinook salmon, and hatchery steelhead observed at the lower Imnaha River trap from February 22 to June 21, 2001.

\begin{tabular}{lccc}
\hline Statistic & $\begin{array}{c}\text { Hatchery } \\
\text { Chinook Salmon }\end{array}$ & $\begin{array}{c}\text { Natural } \\
\text { Chinook Salmon }\end{array}$ & Hatchery Steelhead \\
\hline Mean Fork Length (mm) & 141 & 108 & 213 \\
Sample Size & 2,214 & 95 & 29 \\
Range & $110-180$ & $87-129$ & $123-260$ \\
Standard Deviation & 10.7 & 8.9 & 27.4 \\
& & & \\
Mean Weight (g) & 29.4 & 13.1 & 99.9 \\
Sample Size & 2,059 & 89 & 24 \\
Range & $14.0-61.6$ & $6.8-22.2$ & $59.7-180.8$ \\
Standard Deviation & 6.3 & 3.3 & 33.6 \\
& & & 0.97 \\
Mean Condition Factor (K) & 1.05 & 1.04 & 24 \\
Sample Size & 2,053 & 88 & $0.84-1.05$ \\
Range & $0.73-1.75$ & $0.89-1.24$ & 0.05 \\
Standard Deviation & 0.09 & 0.07 & \\
\hline
\end{tabular}


Table 7. Averages, ranges, and standard deviations for fork lengths (mm), weights (g), and condition factors (K) for PIT tag recaptures of hatchery chinook salmon, natural chinook salmon, and hatchery steelhead observed at the lower Imnaha River trap from March 4 to June 12, 2002.

\begin{tabular}{lccc}
\hline Statistic & $\begin{array}{c}\text { Hatchery } \\
\text { Chinook Salmon }\end{array}$ & $\begin{array}{c}\text { Natural } \\
\text { Chinook Salmon }\end{array}$ & Hatchery Steelhead \\
\hline Mean Fork Length $(\mathrm{mm})$ & 134 & 101 & 202 \\
Sample Size & 558 & 28 & 33 \\
Range & $94-181$ & $86-119$ & $140-238$ \\
Standard Deviation & 14.4 & 6.8 & 20.6 \\
Mean Weight (g) & & & \\
Sample Size & 27.2 & 11.4 & 82.9 \\
Range & 552 & 27 & 31 \\
Standard Deviation & $8.3-61.5$ & $6.9-16.1$ & $26.9-136.2$ \\
& 9.1 & 2.1 & 25.5 \\
Mean Condition Factor (K) & 1.09 & & \\
Sample Size & 552 & 1.08 & 0.97 \\
Range & $0.73-1.81$ & 27 & 31 \\
Standard Deviation & 0.10 & $0.76-1.33$ & $0.85-1.11$ \\
\hline
\end{tabular}

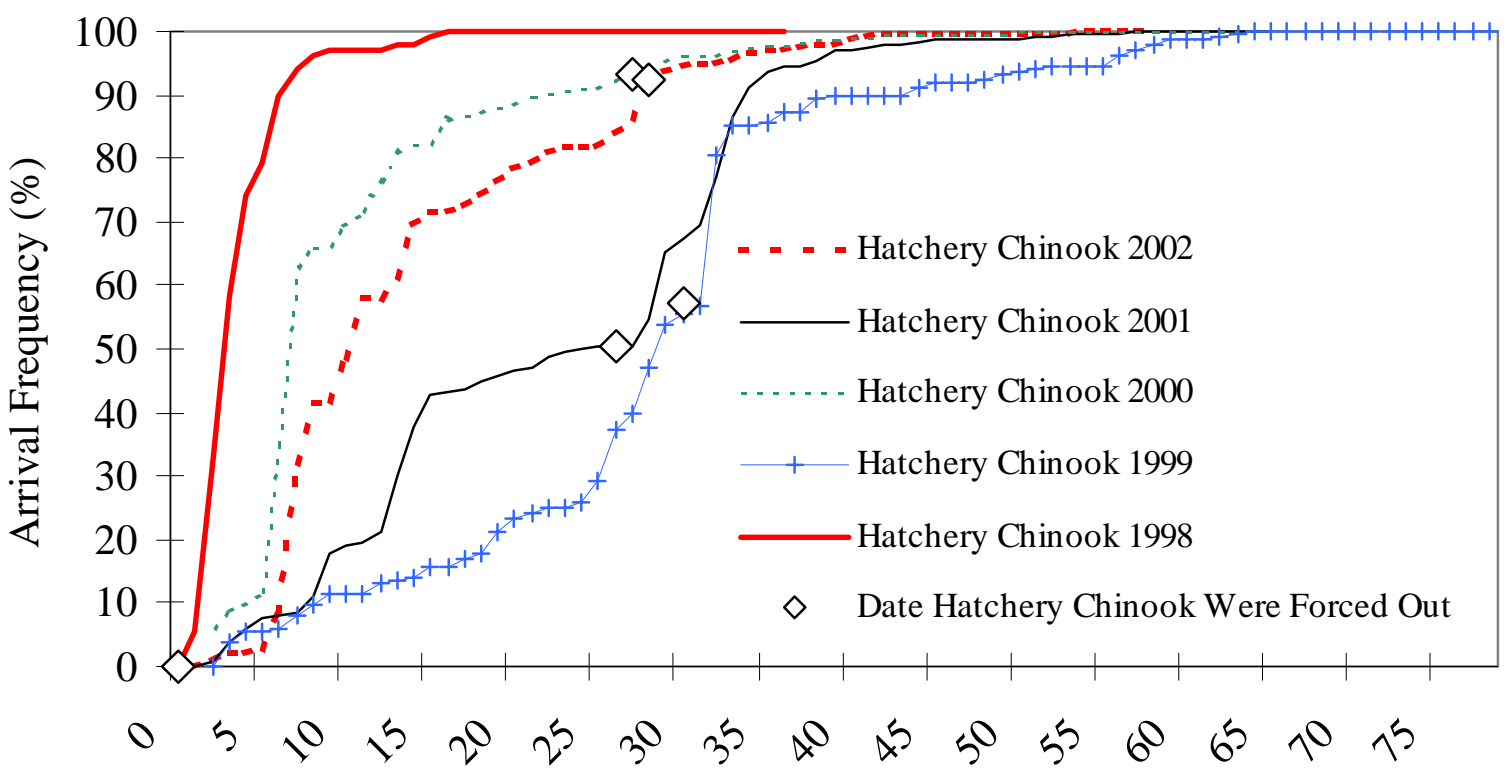

Days After Release

Figure 10. The arrival frequency of previously PIT tagged hatchery chinook salmon captured in the lower Imnaha River trap during the spring of 1998 to the spring of 2002. The release strategy in 1998 was a forced release and the remainder of the releases were volitional. 


\section{Biological Characteristics}

\section{$\underline{\text { Annual Biological Characteristics }}$}

Natural chinook salmon captured during the fall at the upper trap in 2000 averaged 86 $\mathrm{mm}$ in fork length, $7.0 \mathrm{~g}$ in weight and had an average condition factor of 1.05 (Table 8). Natural chinook salmon captured at the lower trap averaged $91 \mathrm{~mm}$ in fork length, $7.9 \mathrm{~g}$ in weight, and had an average condition factor of 1.01. The median fork length for natural chinook salmon captured in the upper trap in the fall of 2000 was $86 \mathrm{~mm}$ and it was significantly smaller (p < 0.05) than the $90 \mathrm{~mm}$ median fork length of natural chinook salmon captured in the lower trap in 2000 (Figure 11). Values for statistical comparisons are shown in Appendix D.

Natural chinook salmon captured during the fall at the upper trap in 2001 averaged 76 $\mathrm{mm}$ in fork length, $6.9 \mathrm{~g}$ in weight, and had an average condition factor of 1.09. At the lower trap, captured natural chinook salmon averaged $85 \mathrm{~mm}$ in fork length, $6.5 \mathrm{~g}$ in weight, and had an average condition factor of 0.97 . There was no significant difference between median fork lengths of natural chinook salmon captured in the upper trap and lower trap during the fall of 2001 ( $p$ > 0.05). Natural chinook salmon in the upper trap had a median fork length of $76 \mathrm{~mm}$ and the natural chinook salmon captured in the lower trap had a median fork length of $85 \mathrm{~mm}$ (Figure 12).

Table 8. A summary of the biological characteristics of natural chinook salmon captured in the upper and lower Imnaha River screw trap from October 17 to November 15, 2000 and from October 15 to November 27, 2001.

\begin{tabular}{lcccc}
\hline & \multicolumn{2}{c}{ Upper Trap } & \multicolumn{2}{c}{ Lower Trap } \\
Statistic & 2000 & 2001 & 2000 & 2001 \\
\hline Mean Fork Length (mm) & 86 & 76 & 91 & 85 \\
Sample Size & 1,788 & 1,385 & 1,994 & 1,888 \\
Range & $66-122$ & $51-120$ & $68-137$ & $57-117$ \\
Standard Deviation & 7.72 & 10.33 & 9.4 & 8.51 \\
& & & & \\
Mean Weight (g) & 7.0 & 6.9 & 7.9 & 6.5 \\
Sample Size & 1,720 & 614 & 1,478 & 1,622 \\
Range & $4.0-19.3$ & $4.1-13.7$ & $4.0-25.9$ & $4.0-18.4$ \\
Standard Deviation & 2.01 & 1.63 & 2.65 & 1.82 \\
& & & & \\
Mean Condition Factor (K) & 1.05 & 1.09 & 1.01 & 0.97 \\
Sample Size & 1,708 & 607 & 1,468 & 1,619 \\
Range & $0.70-1.40$ & $0.77-1.42$ & $0.69-1.40$ & $0.60-1.38$ \\
Standard Deviation & 0.09 & 0.11 & 0.09 & 0.08 \\
\hline
\end{tabular}




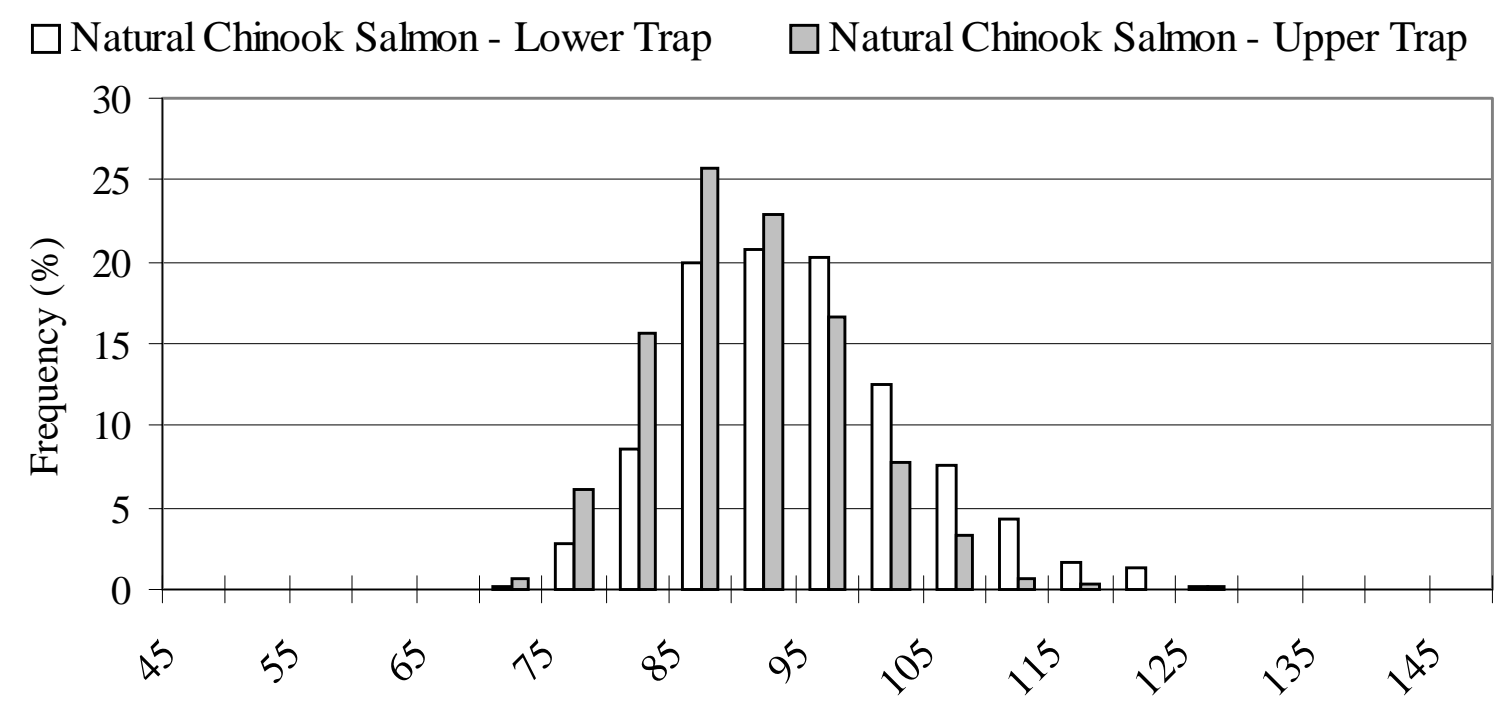

Fork Length (mm)

Figure 11. Length frequency distributions of natural chinook salmon trapped in the upper and lower Imnaha River traps during the fall of 2000.

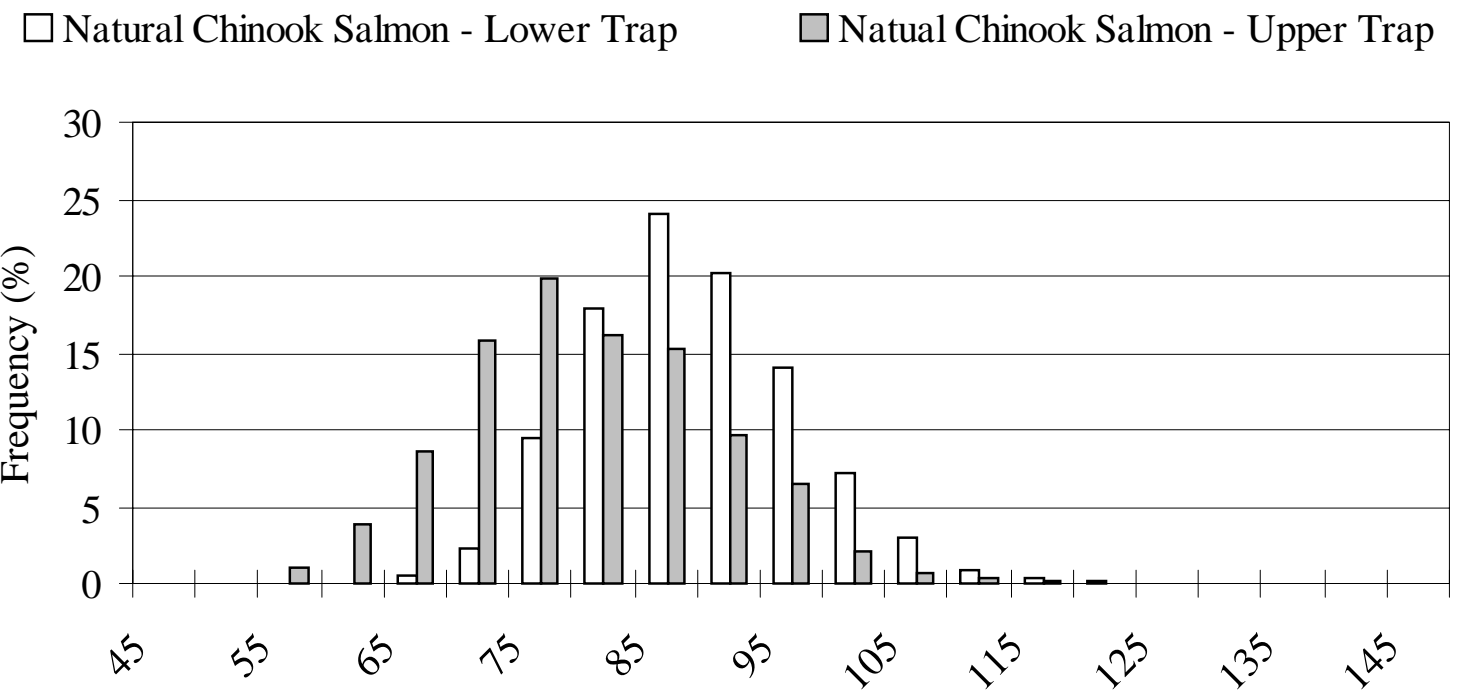

Fork Length (mm)

Figure 12. Length frequency distributions of natural chinook salmon trapped in the upper and lower Imnaha River traps during the fall of 2001. 
A comparison of the median fork lengths of natural chinook salmon captured in the fall of 2000 at the upper and lower traps to the median fork lengths of natural chinook salmon captured in the fall of 2001 at the upper and lower traps showed that natural chinook captured in the fall of 2000 had significantly smaller fork lengths

$(\mathrm{p}<0.05$, Appendix D).

Natural chinook salmon migrating in the spring of 2001 averaged $108 \mathrm{~mm}$ in fork length, $13.0 \mathrm{~g}$, and had an average condition factor of 1.00 (Table 9). The minimum fork length of natural chinook salmon observed was $42 \mathrm{~mm}$. This chinook salmon may have been a young of the year spring chinook salmon or a fall run chinook salmon sub-yearling. Weekly, the average fork length of natural chinook salmon during the spring of 2001 ranged from $97 \mathrm{~mm}$ during the week of June 10 to $113 \mathrm{~mm}$ during the weeks of April 15 and April 22 (Table 10). The condition factors for natural chinook salmon ranged from 0.93 during the week of March 25 to 1.11 during the week of March 11. No significant trends were observed for weekly fork lengths or condition factors.

Hatchery chinook salmon captured in migration year 2001 averaged $142 \mathrm{~mm}, 30.0 \mathrm{~g}$ in weight, and had an average condition factor of 1.03 (Table 9). Weekly mean hatchery chinook salmon fork lengths ranged from $137 \mathrm{~mm}$ during the week of April 29 to $150 \mathrm{~mm}$ during the week of March 18 (Table 10). Mean condition factors for hatchery chinook salmon ranged from 1.00 (week of March 25) to 1.05 (week of April 1 and April 15). The hatchery chinook salmon

Table 9. A summary of the biological characteristics of natural and hatchery chinook salmon and steelhead captured in the lower Imnaha River screw trap from February 22 to June 21, 2001.

\begin{tabular}{lcccc}
\hline & \multicolumn{2}{c}{ Chinook Salmon } & \multicolumn{2}{c}{ Steelhead } \\
Statistic & Natural & Hatchery & Natural & Hatchery \\
\hline Mean Fork Length (mm) & 108 & 142 & 178 & 217 \\
Sample Size & 9,956 & 7,107 & 3,733 & 4,365 \\
Range & $42-165$ & $90-241$ & $120-281$ & $120-310$ \\
Standard Deviation & 10.0 & 12.1 & 24.3 & 22.7 \\
& & & & \\
Mean Weight (g) & 13.0 & 30.0 & 55.5 & 98.2 \\
Sample Size & 9,506 & 6,563 & 3,575 & 4,065 \\
Range & $4.4-43.5$ & $7.3-137.5$ & $11.9-236$ & $14.8-301.9$ \\
Standard Deviation & 3.9 & 7.5 & 24.3 & 31.6 \\
& & & & \\
Mean Condition Factor (K) & 1.00 & 1.03 & 0.94 & 0.93 \\
Sample Size & 9,465 & 6,542 & 3,531 & 4,042 \\
Range & $0.61-1.80$ & $0.67-1.75$ & $0.51-1.62$ & $0.52-1.65$ \\
Standard Deviation & 0.09 & 0.08 & 0.07 & 0.07 \\
\hline
\end{tabular}


Table 10. Weekly mean fork lengths (F.L.) and condition factors (K) for natural and hatchery chinook salmon and steelhead captured at the Imnaha River trap during the spring of 2001. All weekly groups represent 30 or more fish.

\begin{tabular}{|c|c|c|c|c|c|c|c|c|}
\hline \multirow[b]{2}{*}{ Week } & \multicolumn{2}{|c|}{$\begin{array}{c}\text { Natural Chinook } \\
\text { Salmon }\end{array}$} & \multicolumn{2}{|c|}{$\begin{array}{c}\text { Hatchery Chinook } \\
\text { Salmon }\end{array}$} & \multicolumn{2}{|c|}{$\begin{array}{l}\text { Natural } \\
\text { Steelhead }\end{array}$} & \multicolumn{2}{|c|}{$\begin{array}{l}\text { Hatchery } \\
\text { Steelhead }\end{array}$} \\
\hline & $\begin{array}{c}\text { Average } \\
\text { F.L. }(\mathrm{mm})\end{array}$ & $\begin{array}{c}\text { Average } \\
\mathrm{K}\end{array}$ & $\begin{array}{l}\text { Average } \\
\text { F.L. }(\mathrm{mm})\end{array}$ & $\begin{array}{c}\text { Average } \\
\mathrm{K}\end{array}$ & $\begin{array}{c}\text { Average } \\
\text { F.L. (mm) }\end{array}$ & $\begin{array}{c}\text { Average } \\
\mathrm{K}\end{array}$ & $\begin{array}{c}\text { Average } \\
\text { F.L. }(\mathrm{mm})\end{array}$ & $\begin{array}{c}\text { Average } \\
\mathrm{K}\end{array}$ \\
\hline $3 / 11$ & 102 & 1.11 & & & & & & \\
\hline $3 / 18$ & 108 & 0.99 & 150 & 1.03 & 156 & 0.92 & & \\
\hline $3 / 25$ & 107 & 0.93 & 146 & 1.00 & 153 & 0.89 & & \\
\hline $4 / 1$ & 108 & 0.99 & 143 & 1.05 & 174 & 0.90 & & \\
\hline $4 / 8$ & 109 & 1.01 & 141 & 1.04 & 187 & 0.97 & & \\
\hline $4 / 15$ & 113 & 1.01 & 140 & 1.05 & 192 & 0.93 & 218 & 0.96 \\
\hline $4 / 22$ & 113 & 1.04 & 139 & 1.03 & 188 & 0.94 & 214 & 0.95 \\
\hline $4 / 29$ & 105 & 1.03 & 137 & 1.04 & 179 & 0.95 & 221 & 0.96 \\
\hline $5 / 6$ & 109 & 1.00 & 140 & 1.03 & 173 & 0.93 & 219 & 0.93 \\
\hline $5 / 13$ & 103 & 1.03 & & & 178 & 0.95 & 216 & 0.93 \\
\hline $5 / 20$ & 106 & 1.05 & & & 169 & 0.97 & 209 & 0.91 \\
\hline $5 / 27$ & 104 & 1.06 & & & 177 & 0.93 & 214 & 0.92 \\
\hline $6 / 3$ & 104 & 1.08 & & & & & 219 & 0.91 \\
\hline $6 / 10$ & 97 & 1.10 & & & & & 214 & 0.92 \\
\hline $6 / 17$ & & & & & & & 222 & 0.92 \\
\hline
\end{tabular}

captured in the spring of 2001 appeared to have larger fork lengths than the natural chinook salmon captured in the spring of 2001 (Figure 13). The median fork length of hatchery chinook salmon in 2001 was $140 \mathrm{~mm}$ and it was significantly larger $(\mathrm{p}<0.05)$ than the $108 \mathrm{~mm}$ median natural chinook salmon fork length.

The natural steelhead captured in the spring of 2001 averaged $178 \mathrm{~mm}$ in fork length. Natural steelhead averaged $55.5 \mathrm{~g}$ in weight and had an average condition factor of 0.94 (Table 9). The largest weekly mean fork lengths for natural steelhead were observed during the week of April $15(192 \mathrm{~mm})$. The smallest mean fork lengths for natural steelhead $(153 \mathrm{~mm})$ were observed during the week of March 25. Weekly mean condition factors for natural steelhead ranged from 0.89 during the week of March 25 to 0.97 . Weekly mean natural steelhead condition factors of 0.97 were observed during the week of April 8 and May 20 (Table 10).

The hatchery steelhead released during the spring of 2001 and captured at the lower Imnaha River trap averaged $217 \mathrm{~mm}$ in fork length, $98.2 \mathrm{~g}$ in weight, and had an average condition factor of 0.93 (Table 9). Hatchery steelhead weekly mean fork lengths ranged from $209 \mathrm{~mm}$ during the week of May 20 to $222 \mathrm{~mm}$ during the week of June 17. Weekly mean condition factors ranged from 0.91 during the weeks of May 20 and June 3 to 0.96 during the week of April 29 (Table 10). Hatchery steelhead smolt median fork length in 2001 (217 mm) was statistically larger $(\mathrm{p}<0.05)$ than the median fork length $(175 \mathrm{~mm})$ for natural steelhead in 2001 (Appendix D, Figure 14). 


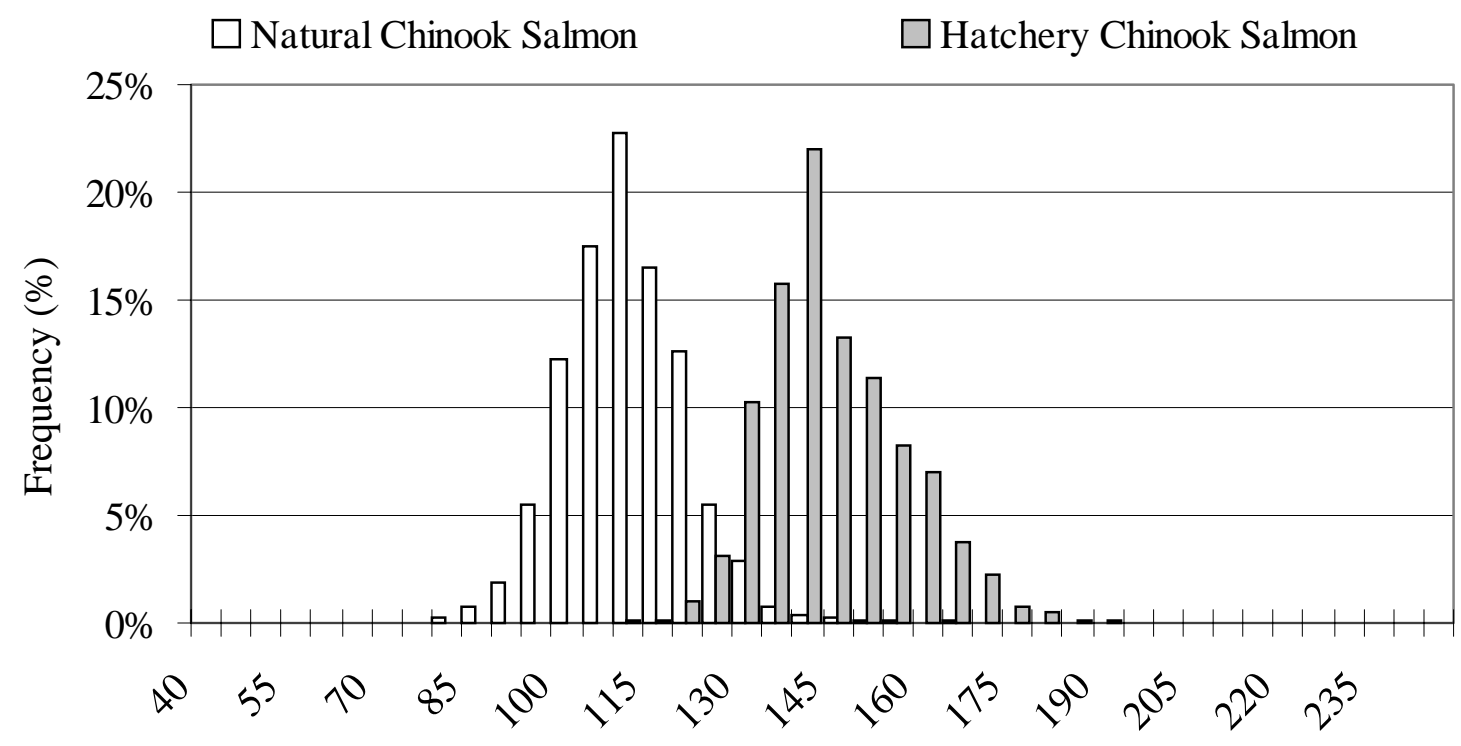

Fork Length (mm)

Figure 13. Length frequency distribution of natural and hatchery chinook salmon trapped in the lower Imnaha River trap, February 22 to June 21, 2001.

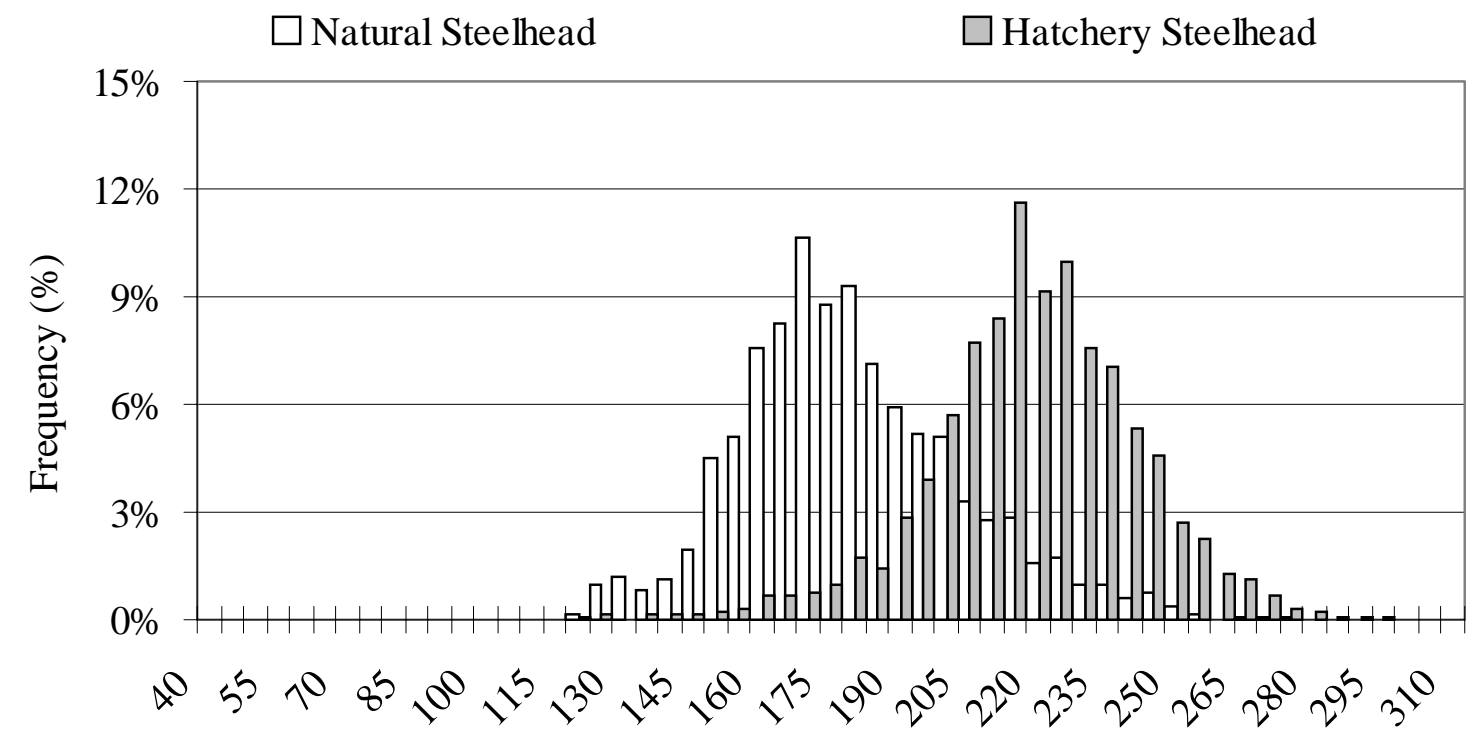

Fork Length (mm)

Figure 14. Length frequency distribution of natural and hatchery steelhead trapped in the lower Imnaha River trap, February 22 to June 21, 2001. 
Natural chinook salmon observed during the spring of 2002 averaged $104 \mathrm{~mm}$ in fork length, $12.3 \mathrm{~g}$ in weight, and had an average condition factor of 1.05 (Table 11). As in 2001, the minimum fork length of a natural chinook salmon captured $(34 \mathrm{~mm})$ indicates that natural subyearling spring chinook salmon or fall chinook salmon may be present in the catch. The weekly mean fork lengths for natural chinook salmon captured in 2002 increased from $101 \mathrm{~mm}$ during the week of March 24 to 109 mm during the week of May 12 (Table 12). Weekly mean condition factors for natural chinook salmon ranged from 1.02 during the weeks of March 31 and April 28 to 1.10 during the week of April 14.

Hatchery chinook salmon captured in 2002 weighed in at $28.5 \mathrm{~g}$ and had an average fork length of $139 \mathrm{~mm}$ and an average condition factor of 1.06. Hatchery chinook salmon weekly mean fork lengths observed during the spring of 2002 tended to decrease over time. The largest weekly mean fork length was observed during the week of March 17 (153 mm) and the smallest was observed during the week of May $5(131 \mathrm{~mm})$. Condition factors ranged from 0.99 during the week of May 12 to 1.08 during the week of April 14 for hatchery chinook salmon.

Hatchery chinook salmon captured in the spring of 2002 had significantly larger median fork lengths than natural chinook salmon ( $\mathrm{p}<0.05$, Figure 15). The median fork length for hatchery chinook salmon was $136 \mathrm{~mm}$ and the median fork length for natural chinook salmon was $104 \mathrm{~mm}$. The supplementation program for Imnaha River has produced hatchery chinook salmon smolts that are significantly larger than natural chinook salmon smolts (Kucera and Blenden 1998, Blenden et al. 1998, Cleary et al. 2000, Cleary et al. 2002, and Cleary et al. 2003).

Natural steelhead captured in 2002 had an average fork length of $172 \mathrm{~mm}$, an average weight of $51.1 \mathrm{~g}$, and an average condition factor of 0.96 . The range of weekly mean fork lengths for natural steelhead ranged from $143 \mathrm{~mm}$ during the week of March 31 to $176 \mathrm{~mm}$ during the week of May 12. The weekly mean condition factors for natural steelhead during the spring of 2002 ranged from 0.94 (week of May 12) to 1.03 (week of April 14).

Hatchery steelhead migrating in the spring of 2002 averaged $216 \mathrm{~mm}$ in length, $102.7 \mathrm{~g}$ in weight, and had an average condition factor of 0.99 . Hatchery steelhead weekly mean fork lengths from the week of April 7 to the week of May 12 ranged from $217 \mathrm{~mm}$ during the week of April 21 to $223 \mathrm{~mm}$ during the week of May 5. Weekly mean fork lengths for hatchery steelhead observed from the week of May 19 to the week of June 9 ranged from $201 \mathrm{~mm}$ to 213 mm during the weeks of June 2 to May 26, respectively. Weekly condition factors for these four weeks range from 0.93 for the weeks of May 26 and June 9 to 0.98 for the week of May 19.

The median fork length for hatchery steelhead $(217 \mathrm{~mm})$ was statistically larger $(\mathrm{p}<0.05)$ than the median fork length for natural steelhead $(172 \mathrm{~mm}$ ) in 2002 (Figure 16). Significant differences between hatchery and natural steelhead fork lengths have been documented (Blenden et al. 1998, Cleary et al. 2000, Cleary et al. 2002, and Cleary et al. 2003). 
Table 11. A summary of the biological characteristics of natural and hatchery chinook salmon and steelhead captured in the lower Imnaha River screw trap from March 4 to June 12, 2002.

\begin{tabular}{lcccc}
\hline & \multicolumn{2}{c}{ Chinook Salmon } & \multicolumn{2}{c}{ Steelhead } \\
Statistic & Natural & Hatchery & Natural & Hatchery \\
\hline Mean Fork Length (mm) & 104 & 139 & 172 & 216 \\
Sample Size & 2,333 & 3,918 & 4,738 & 2,428 \\
Range & $34-213$ & $84-273$ & $84-259$ & $116-292$ \\
Standard Deviation & 11.4 & 16.9 & 19.8 & 21.2 \\
& & & & \\
Mean Weight (g) & 12.3 & 28.5 & 51.1 & 102.7 \\
Sample Size & 2,020 & 3,029 & 3,922 & 2,305 \\
Range & $4.2-100.2$ & $4.3-212.8$ & $5.7-176.1$ & $5.0-252.6$ \\
Standard Deviation & 5.4 & 11.9 & 17.3 & 31.4 \\
& & & & \\
Mean Condition Factor (K) & 1.05 & 1.06 & 0.96 & 0.99 \\
Sample Size & 2,006 & 3,000 & 3,868 & 2,282 \\
Range & $0.73-1.70$ & $0.73-1.68$ & $0.71-1.72$ & $0.74-1.37$ \\
Standard Deviation & 0.09 & 0.08 & 0.07 & 0.08 \\
\hline
\end{tabular}

Table 12. Weekly mean fork lengths (F.L.) and condition factors (K) for natural and hatchery chinook salmon and steelhead captured at the Imnaha River trap during the spring of 2002. All weekly groups represent 30 or more fish.

\begin{tabular}{|c|c|c|c|c|c|c|c|c|}
\hline \multirow[b]{2}{*}{ Week } & \multicolumn{2}{|c|}{$\begin{array}{c}\text { Natural Chinook } \\
\text { Salmon }\end{array}$} & \multicolumn{2}{|c|}{$\begin{array}{c}\text { Hatchery Chinook } \\
\text { Salmon }\end{array}$} & \multicolumn{2}{|c|}{$\begin{array}{c}\text { Natural } \\
\text { Steelhead }\end{array}$} & \multicolumn{2}{|c|}{$\begin{array}{l}\text { Hatchery } \\
\text { Steelhead }\end{array}$} \\
\hline & $\begin{array}{l}\text { Average } \\
\text { F.L. }(\mathrm{mm})\end{array}$ & $\begin{array}{c}\text { Average } \\
\mathrm{K}\end{array}$ & $\begin{array}{l}\text { Average } \\
\text { F.L. }(\mathrm{mm})\end{array}$ & $\begin{array}{c}\text { Average } \\
\text { K }\end{array}$ & $\begin{array}{l}\text { Average } \\
\text { F.L. }(\mathrm{mm})\end{array}$ & $\begin{array}{c}\text { Average } \\
\text { K }\end{array}$ & $\begin{array}{l}\text { Average } \\
\text { F.L. }(\mathrm{mm})\end{array}$ & $\begin{array}{c}\text { Average } \\
\text { K }\end{array}$ \\
\hline $3 / 17$ & & & 153 & 1.07 & & & & \\
\hline $3 / 24$ & 101 & 1.03 & 147 & 1.05 & 145 & & & \\
\hline $3 / 31$ & 101 & 1.02 & 142 & 1.06 & 143 & & & \\
\hline $4 / 7$ & 101 & 1.05 & 135 & 1.07 & 158 & 0.98 & 222 & 1.08 \\
\hline $4 / 14$ & 103 & 1.10 & 135 & 1.08 & 172 & 1.03 & 218 & 1.03 \\
\hline $4 / 21$ & 106 & 1.05 & 135 & 1.03 & 168 & 0.98 & 217 & 1.02 \\
\hline $4 / 28$ & 108 & 1.02 & 137 & 1.01 & 175 & 0.95 & 221 & 0.97 \\
\hline $5 / 5$ & 105 & 1.05 & 131 & 1.03 & 175 & 0.97 & 223 & 1.00 \\
\hline $5 / 12$ & 109 & 1.04 & 132 & 0.99 & 176 & 0.94 & 222 & 0.96 \\
\hline $5 / 19$ & & & & & 171 & 1.00 & 210 & 0.98 \\
\hline $5 / 26$ & & & & & 166 & 0.96 & 213 & 0.93 \\
\hline $6 / 2$ & & & & & 163 & 1.01 & 201 & 0.95 \\
\hline $6 / 9$ & & & & & 166 & 0.98 & 202 & 0.93 \\
\hline
\end{tabular}




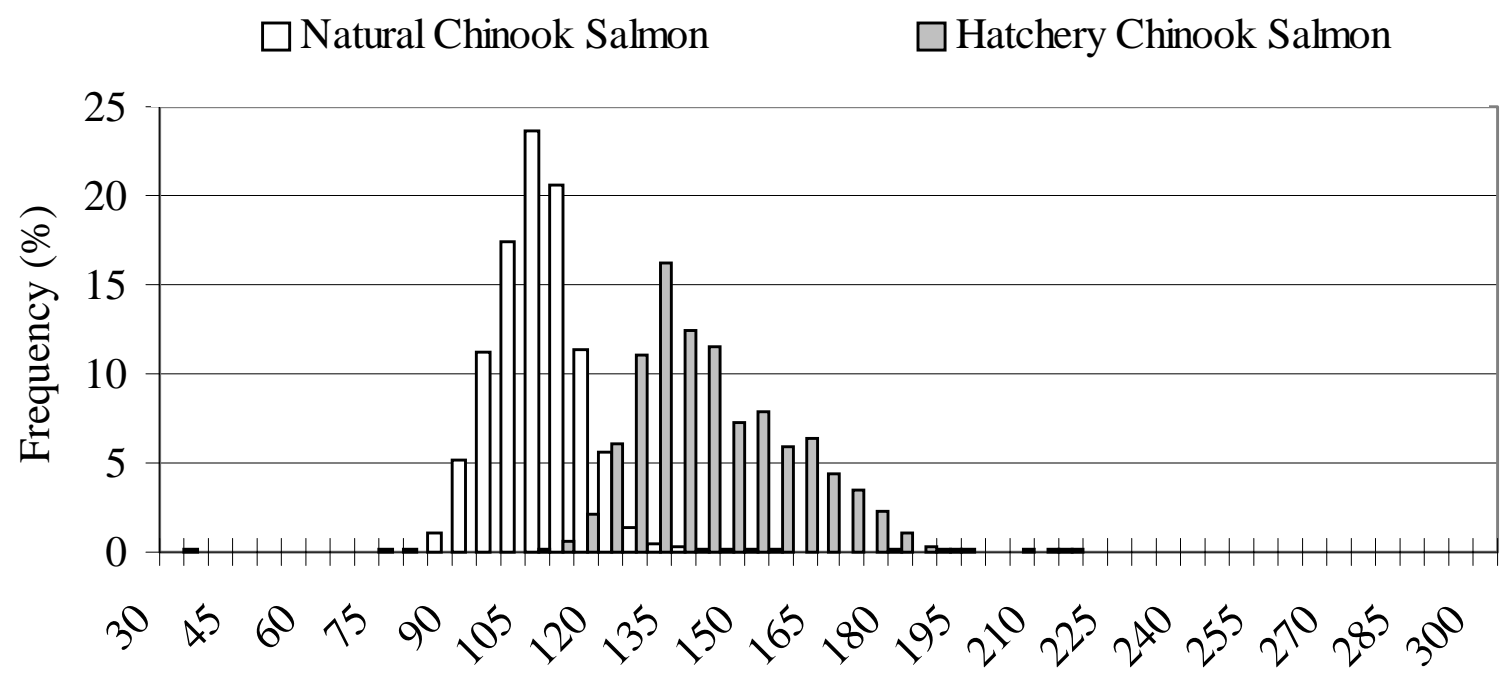

Fork Length (mm)

Figure 15. Length frequency distribution of natural and hatchery chinook salmon trapped in the lower Imnaha River trap, March 4 to June 12, 2002.

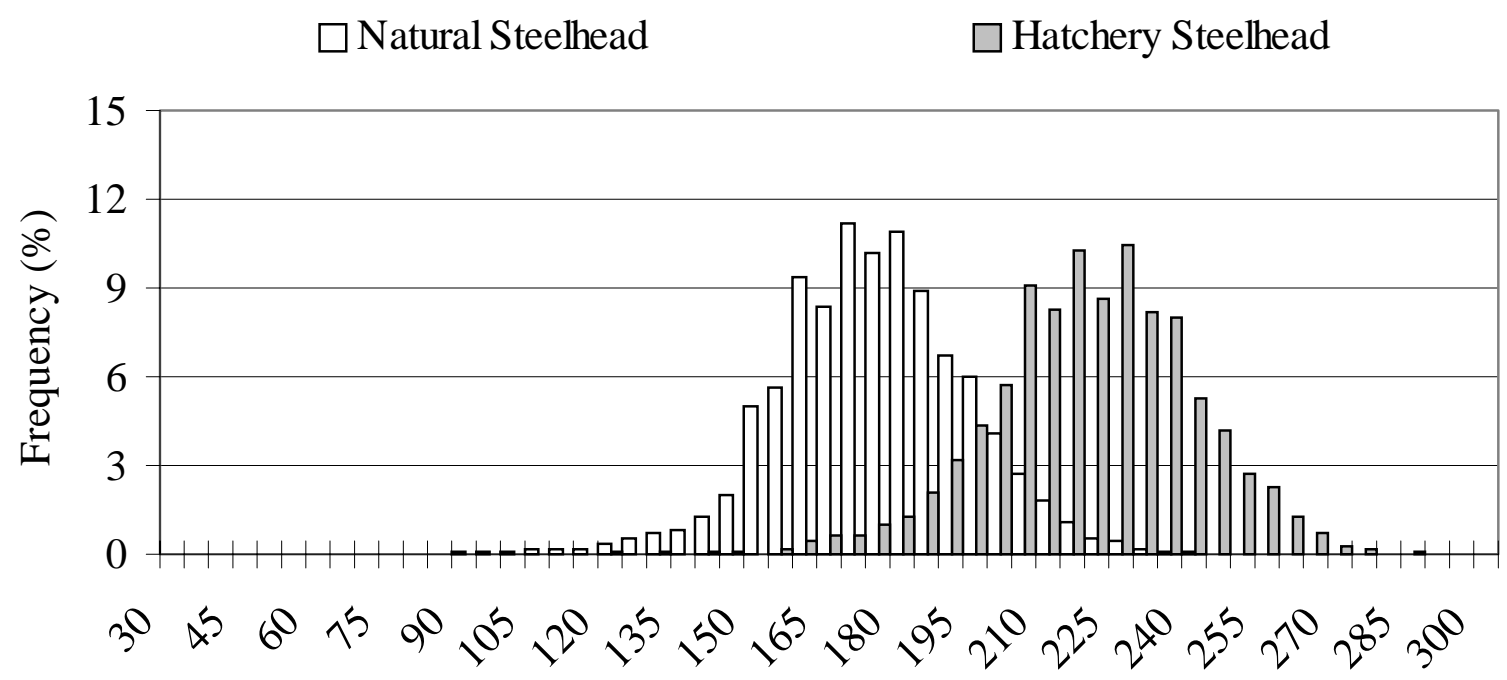

Fork Length (mm)

Figure 16. Length frequency distribution of natural and hatchery steelhead trapped in the lower Imnaha River trap, March 4 to June 12, 2002. 


\section{$\underline{\text { Survival of PIT Tagged Smolts }}$}

\section{Chinook Salmon Post Release Survival and Abundance}

Post release survival of hatchery chinook salmon smolts from the Imnaha River acclimation facility to the lower Imnaha River trap in 2001 was $93.9 \%$ (95\% C.I. $\pm 1.9 \%$ ) (Figure 17). Estimated survival from the acclimation facility to the lower Imnaha River trap was $90.2 \%$ in 2002 (95\% C.I. $\pm 3.7 \%$ ). Since 1994, post release survival estimates calculated with SURPH have ranged from $100.9 \%$ in 1994 to $88.4 \%$ in 1998. Post release survival estimates using the SURPH model are possible when substantial numbers of PIT tagged fish are released at the acclimation facility. Since 1998 PIT tag interrogations of hatchery chinook salmon at the lower Imnaha River trap have ranged from 4.5\% in 1999 to 19.6\% in 1997 (Appendix Table E1).

Trap efficiency trials for Bootstrap population estimates were conducted for hatchery chinook salmon. The $29.1 \%$ annual trap efficiency for hatchery chinook salmon in 2001 was based on six trials conducted from March 28 to April 8 (Appendix Table E2). The trials were conducted when conditions permitted and may have over-represented the trap efficiency. If the annual trap efficiency for 2001 was used in a post release survival estimate for hatchery chinook salmon it would result in a survival estimate that is $29.7 \%$ less than the survival estimate produced by the SURPH model from the acclimation facility to LGR (Appendix Table E1).

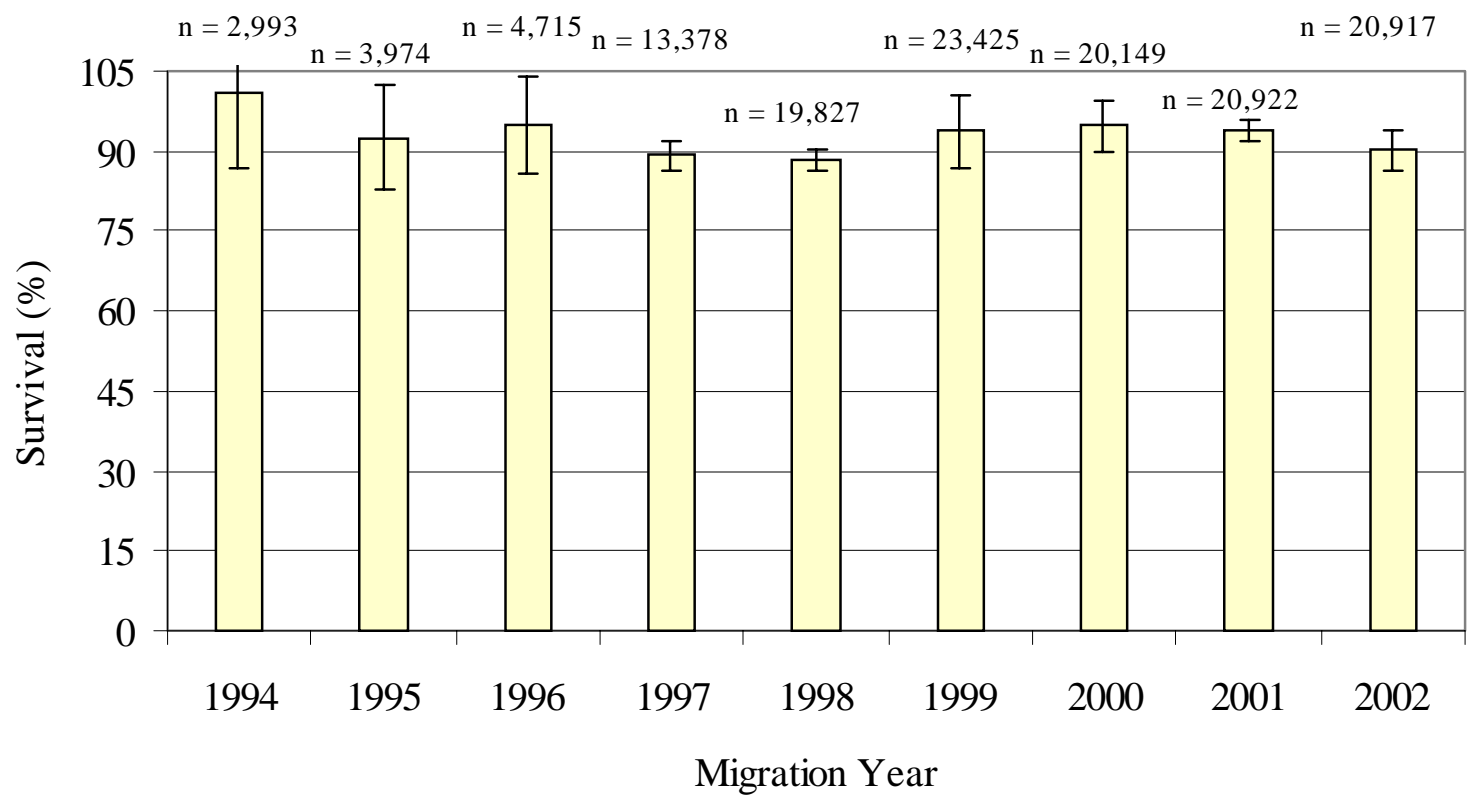

Figure 17. Annual survival of hatchery chinook salmon from the Imnaha River acclimation facility to the lower Imnaha River trap from 1994 to 2002. The size of annual PIT tag release groups are shown above for each year and error bars indicate the 95\% C.I.. 
Thirty-nine trap efficiency trials using hatchery chinook salmon were conducted from March 25, 2002 to May 18, 2002 (Appendix Table E3). The annual trap efficiency trial for hatchery chinook salmon in 2002 was $9.1 \%$. The resulting Bootstrap generated a survival estimate that differed from the SURPH estimate by $5.3 \%$. The relatively small difference between the Bootstrap and SURPH survival estimates in 2002 may be due to the greater number of trials in 2002 that were conducted over a wider range of trapping conditions.

Natural chinook salmon were released and marked in 36 trap efficiency trials from March 25 to May 18, 2002 (Appendix Table E3). The resulting trap efficiency for natural chinook salmon for 2002 was $7.1 \%$. This appeared to be an accurate representation of the lower traps collection efficiency in 2002 because it concurred with the $9.1 \%$ trap efficiency trial estimate for hatchery chinook salmon and the 7.3\% PIT tag interrogation percent (Appendix Table E1). An estimated 7,646 to 23,249 (95\% C.I.) natural chinook salmon smolts migrated past the lower Imnaha River trap from April 4 to April 22. An additional 6,767 to 14,706 (95\% C.I.) natural chinook salmon smolts migrated past the lower Imnaha River trap from April 23 to May 14. These estimates do not represent the total spring emigrant smolt abundance in the Imnaha River in 2002. No point estimates are available for the fall because trapping efforts were only designed to collect fish for PIT tagging and estimating survival of to LGR.

\section{Estimated Season Wide Smolt Survival}

Survival of fall tagged natural chinook salmon from the upper trap to LGR was estimated to be $28.8 \%( \pm 2.1 \%$ ) for the 2001 migration year (Figure 18). The survival of fall tagged natural chinook salmon from the lower trap to LGR for migration year 2001 was $41.1 \%$ (95\% C.I. of $\pm 2.1 \%$ ). During the 2002 migration year estimated survival from the upper trap to LGR was $21.9 \%$ (95\% C. I. of $\pm 3.3 \%)$ and survival from the lower trap to LGR was $33.3 \%$ (95\% C. I. of $\pm 3.3 \%$ ). Survival estimates from the upper trap have ranged from $22.4 \%$ for migration year 1994 to $45.9 \%$ for migration year 1998. Estimated survival of fall tagged chinook salmon from the lower trap to LGR have ranged from $25.6 \%$ in 1994 to $60.4 \%$ in 1998 . Estimated survival of fall tagged juvenile natural chinook salmon from the lower trap to LGR has ranged from 5.9\% to $16.9 \%$ higher than fall tagged fish from the upper trap from 1994 to 2002.

Season-wide estimated smolt survival for natural chinook salmon is presented with $95 \%$ confidence intervals in parentheses (Table 13). Natural chinook salmon tagged in the spring of 2001 at the lower trap survived to LGR at a rate of $83.7 \%( \pm 0.8 \%)$. Estimates of survival from release to LMO and release to MCN were noticeably less at $65.6 \%( \pm 1.3 \%)$ and $47.4 \%( \pm$ $1.5 \%)$, respectively. The hatchery chinook salmon survival estimate from release to LGR for 2001 was less than the estimate for natural chinook salmon at $80.3 \%( \pm 1.6 \%)$. But survival estimates of $68.9 \%( \pm 2.5 \%)$ from release to LMO and $52.1 \%( \pm 5.3 \%)$ to MCN were higher than for natural chinook salmon. Natural and hatchery steelhead released in 2001 had an 


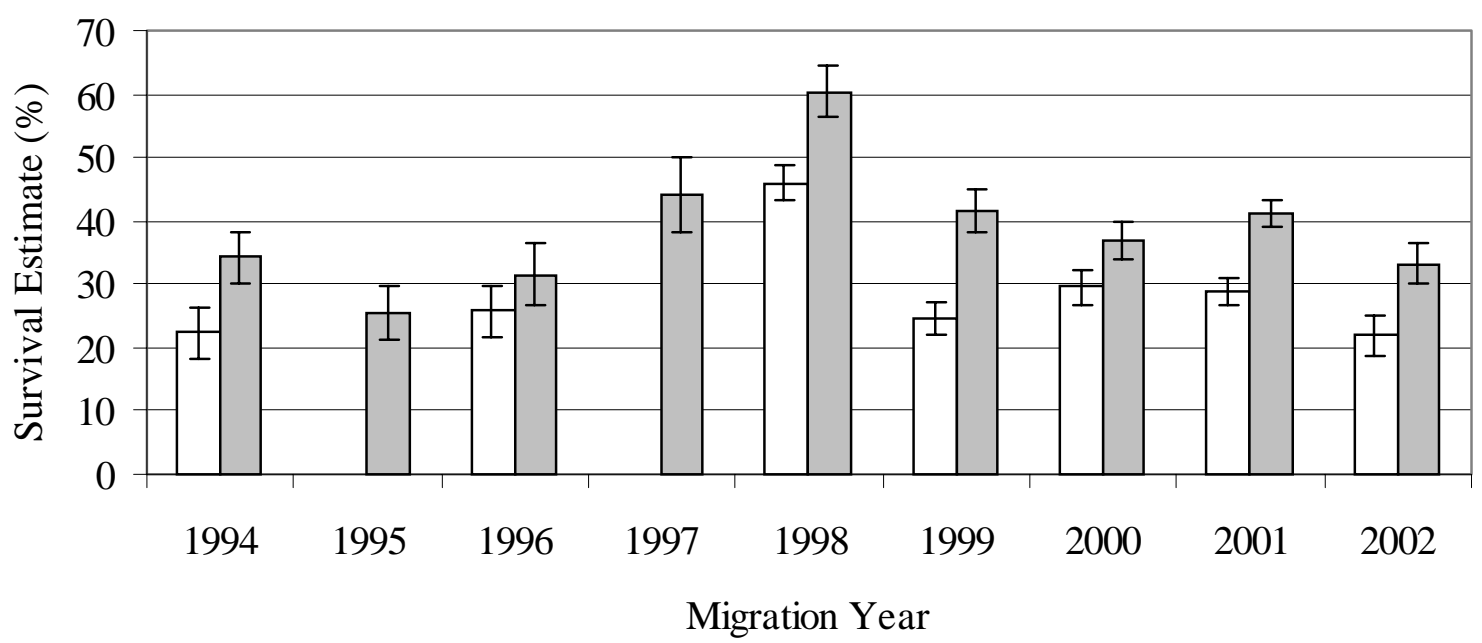

Figure 18. Estimated survival of natural chinook salmon PIT tagged and released in the fall from the upper and lower Imnaha River traps, to Lower Granite Dam, for migration years 1994 to 2002.

estimated survival within the range of the 2001 chinook salmon of $82.7 \%( \pm 1.3 \%)$ and $82.0 \%$ $( \pm 1.6 \%)$, respectively, from the trap to LGR. However, the 2001 natural steelhead survival estimates from the trap to LMO $(49.7 \% \pm 3.5 \%)$ represented the poorest survival documented from 1997 to 2002 (Table 13). Hatchery steelhead survival from the trap to LMO was even lower, at $42.9 \%( \pm 6.0 \%)$. The survival estimate for natural steelhead from release to MCN was only $18.4 \%( \pm 3.1 \%)$ and was the worst ever recorded. The survival estimate for hatchery steelhead from release to $\mathrm{MCN}$ was $13.9 \%( \pm 3.9 \%)$.

The 2002 season wide survival estimate from release to LGR was as follows: natural chinook salmon $-86.9 \%$ ( $\pm 4.4 \%)$, hatchery chinook salmon $-77.3 \%( \pm 4.4 \%)$, natural steelhead $-81.8 \%( \pm 3.5 \%)$, and hatchery steelhead $-83.0 \%( \pm 5.4 \%)$. Natural chinook salmon survived from the trap to $\mathrm{LMO}$ at a rate of $76.8 \%( \pm 4.5 \%)$ an to $\mathrm{MCN}$ at a rate of $61.9 \%( \pm 5.3 \%)$. Hatchery chinook estimated survival from the trap to LMO was $68.1 \%( \pm 4.2 \%)$ and $56.0 \%( \pm$ $5.6 \%$ ) from the trap to $\mathrm{MCN}$. Natural and hatchery steelhead estimated survival from release to LMO was $69.9 \%( \pm 4.5 \%)$ and $78.0 \%( \pm 8.4 \%)$, respectively. The estimated survival of natural steelhead from release to $\mathrm{MCN}$ was poor $(37.0 \% \pm 4.8 \%)$ and was less than estimated hatchery steelhead survival of $48.7 \%$ in 2002 . The hatchery steelhead survival estimate was much more variable with a $95 \%$ C.I. of $\pm 13.2 \%$.

Migration conditions in the mainstem corridor in 2001 were poor and represented drought conditions. Natural chinook salmon survival estimates from the trap to LGR for 2001 and 2002 fit into the past range of estimates (76.2\% to 90.9\%) documented from 1993 to 2002 (Figure 19). Imnaha River natural chinook salmon smolt survival to LMO (Table 13) and MCN in 2001 
Table 13. Estimated survival probabilities for season-wide PIT tag release groups of natural and hatchery chinook salmon and steelhead smolts released from the lower Imnaha River trap from February 22 to June 21, 2001 and March 4 to June 12, 2002 with 95\% confidence intervals in parentheses. Estimates are from release to the tail race for the trap to Lower Granite Dam and tail race to tail race for all other sites. Abbreviations: LGR -Lower Granite Dam, LGO - Little Goose Dam, LMO - Lower Monumental Dam, MCN -McNary Dam.

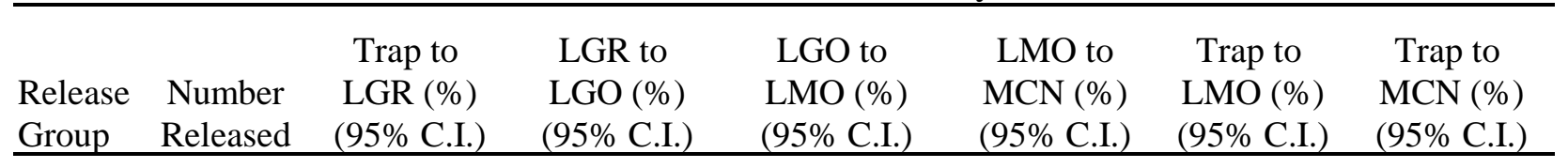

Spring PIT Tag Releases in 2001

Natural Chinook Salmon

$$
10,005 \quad 83.7(0.8) \quad 94.0(0.9) \quad 83.5(1.5) \quad 72.1(2.1) \quad 65.6(1.3) \quad 47.4(1.5)
$$

Hatchery Chinook Salmon

$3,008 \quad 80.3(1.6) \quad 95.6(1.7) \quad 89.8(2.9) \quad 75.5(4.4) \quad 68.9(2.5) \quad 52.1(5.3)$

Natural Steelhead

$3,678 \quad 82.7(1.3) \quad 82.1(2.1) \quad 73.2(5.0) \quad 37.1(5.8) \quad 49.7(3.5) \quad 18.4(3.1)$

Hatchery Steelhead

$3,463 \quad 82.0(1.6) \quad 73.8(4.1) \quad 70.8(10.3) \quad 32.3(9.9) \quad 42.9(6.0) \quad 13.9(3.9)$

Spring PIT Tag Releases in 2002

Natural Chinook Salmon

$2,321 \quad 86.9(4.4) \quad 88.9(5.6) \quad 99.5(6.7) \quad 80.5(8.0) \quad 76.8(4.5) \quad 61.9(5.3)$

Hatchery Chinook Salmon

$3,021 \quad 77.3(4.4) \quad 91.5(6.6) \quad 96.2(7.1) \quad 82.2(9.2) \quad 68.1(4.2) \quad 56.0(5.6)$

Natural Steelhead

$4,808 \quad 81.8(3.5) \quad 88.6(5.1) \quad 96.6(7.1) \quad 52.9(7.7) \quad 69.9(4.5) \quad 37.0(4.8)$

Hatchery Steelhead

$2,153 \quad 83.0(5.4) \quad 96.5(9.5) \quad 97.4(12.7) \quad 62.4(18.1) \quad 78.0(8.4) \quad 48.7(13.2)$

represented the worst survival recorded by this study. Estimated hatchery chinook salmon survival from 2001 and 2002 also fit into the past range of estimates from 1994 to 2000 of $67.1 \%$ (1994) to $80.4 \%$ in 1997 (Figure 20). Season wide estimates of survival for natural steelhead for 2001 and 2002 were lower than the range of estimates from 1995 to 2000 of $83.7 \%( \pm 7.1 \%)$ in 
1995 to $90.1 \%$ ( $\pm 3.9 \%$ ) in 1997 (Figure 21). The season wide survival estimates from the trap to LGR for hatchery steelhead in 2001 and 2002 were within the range of past estimates from 1995 to 2000 of $64.6 \%$ in 1996 to $85.8 \%$ ( $\pm 2.4 \%$ ) in 2000 (Figure 22).

The lowest estimate of survival from 1998 to 2002 from the lower trap to LMO for spring tagged natural chinook salmon, natural steelhead, and hatchery steelhead occurred in 2001 (Table 14). This is not a surprising result given the drought condition and lack of spill that occurred in 2001. What was surprising was that the highest estimate of survival for hatchery chinook salmon from release at the lower Imnaha River trap to LMO occurred in 2001; 68.9\% $( \pm 2.5 \%)$. The lowest season wide estimate from the lower trap to LMO for hatchery chinook was $54.9 \%$ in 2000. The highest estimate of season wide survival for spring tagged natural chinook salmon from release to LMO was $78.3 \%$ and it occurred in 1999. Natural steelhead survival from release to LMO has been as high as $75.1 \%$ in 1999 and hatchery steelhead survival from release to LMO reached a high of $78.0 \%$ in 2002 .

\section{Estimated Weekly Smolt Survival}

Weekly survival estimates from release to LMO are presented in Table 15 and 16 for the purpose of determining if any weekly trends existed in smolt survival from release to LMO for 2001 and 2002. Weekly survival estimates from release to LGR, LGR to LGO, and LGO to LMO are also presented in Table 15 and 16 for spring tagged natural chinook salmon and steelhead in 2001 and 2002 for the benefit of the reader. All survival estimates below are presented with 95\% confidence intervals in parentheses.

Survival estimates of weekly release groups of spring tagged natural chinook salmon to LMO in 2001 ranged from $50.8 \%( \pm 8.8 \%)$ for the April 29 release group to $71.2 \%( \pm 3.7 \%)$ for the April 15 release group (Table 15). No discernable trend was evident in weekly survival to LMO in 2001. Weekly survival of hatchery chinook salmon ranged from $60.7 \%( \pm 5.6 \%)$ for releases that occurred during the week of March 25 to $78.2 \%$ ( $\pm 6.0 \%$ ) for releases that occurred during the week of April 15. Other than the fact that the weekly survival estimates peaked the same week as they did for natural chinook salmon, there are no notable trends. Weekly survival estimates for natural steelhead declined over a three week period from $66.4 \%( \pm 11.9 \%)$ for the week of April 22 to $42.6 \%$ ( $\pm 4.6 \%$ ) for releases that occurred during the week of May 6 . Hatchery steelhead survival estimates from release to LMO were relatively low and quite variable. Hatchery steelhead weekly survival estimates ranged from $38.1 \%( \pm 13.5 \%)$ for the April 29 release group to $51.5 \%$ ( $\pm 14.0 \%)$ for the May 6 relese group.

Estimated weekly survival to LMO of natural chinook salmon smolts in 2002 declined from $87.1 \%$ ( $\pm 15.4 \%$ ) for the April 7 release group to $66.6 \%$ ( $\pm 9.5 \%$ ) for the April 28 release group (Table 16). Confidence intervals around the survival point estimates were quite robust. Weekly survival estimates of hatchery chinook salmon smolts ranged from $61.3 \%( \pm 10.0 \%)$ for the April 


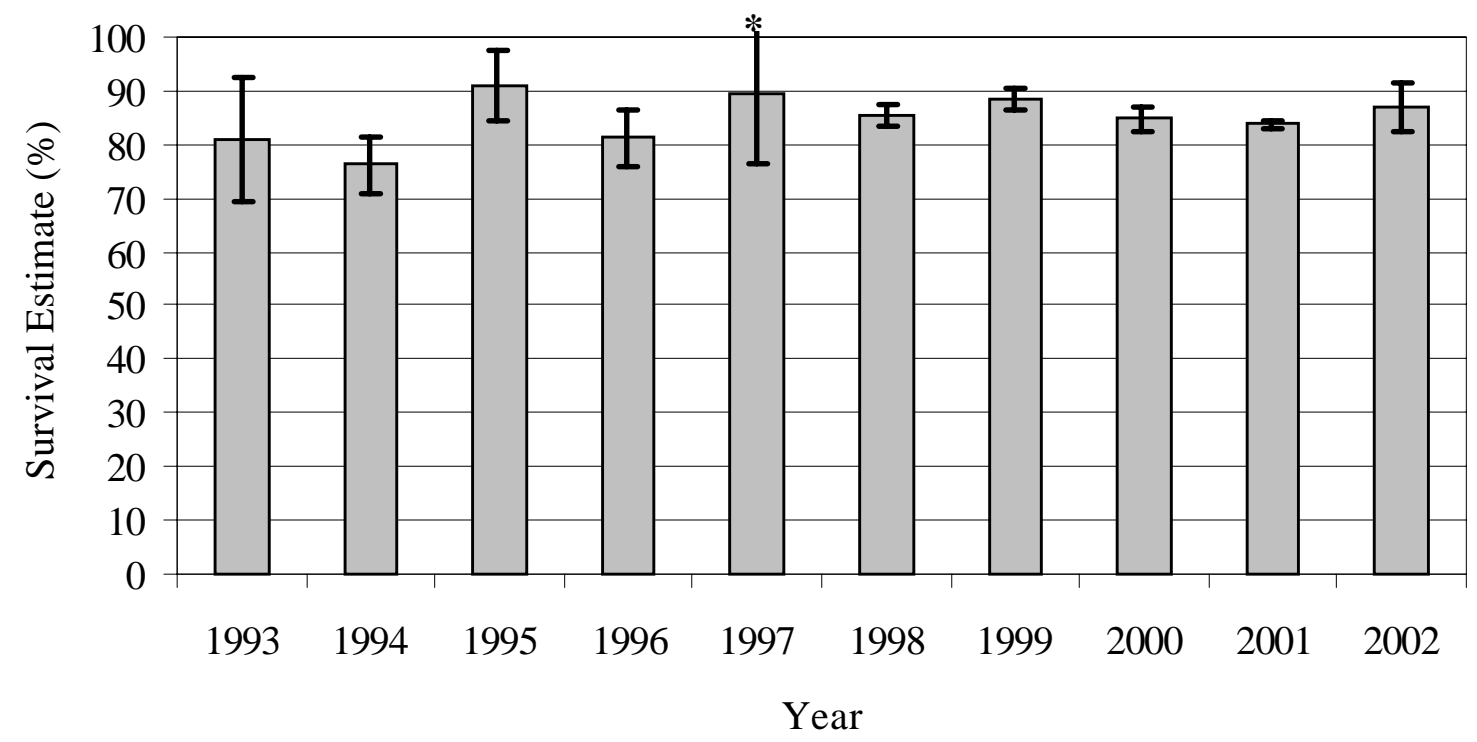

Figure 19. Season-wide survival estimates for natural chinook salmon released from the lower Imnaha River trap to Lower Granite Dam from 1993 to 2002. Error bars indicate 95\% confidence limits. The asterisk indicates upper confidence limit exceeds $100 \%$.

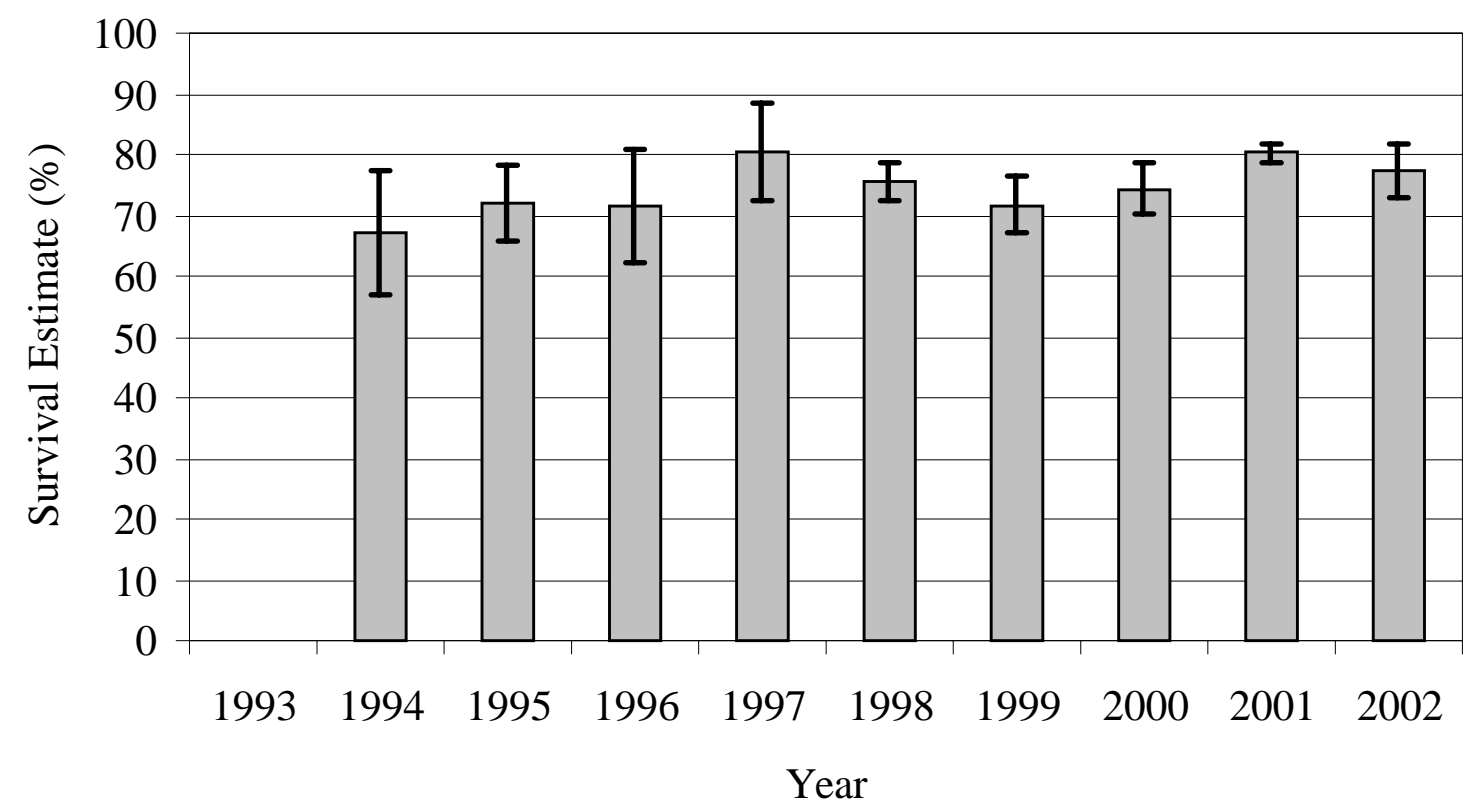

Figure 20. Season-wide survival estimates for hatchery chinook salmon released from the lower Imnaha River trap to Lower Granite Dam from 1994 to 2002. Error bars indicate 95\% confidence limits. 


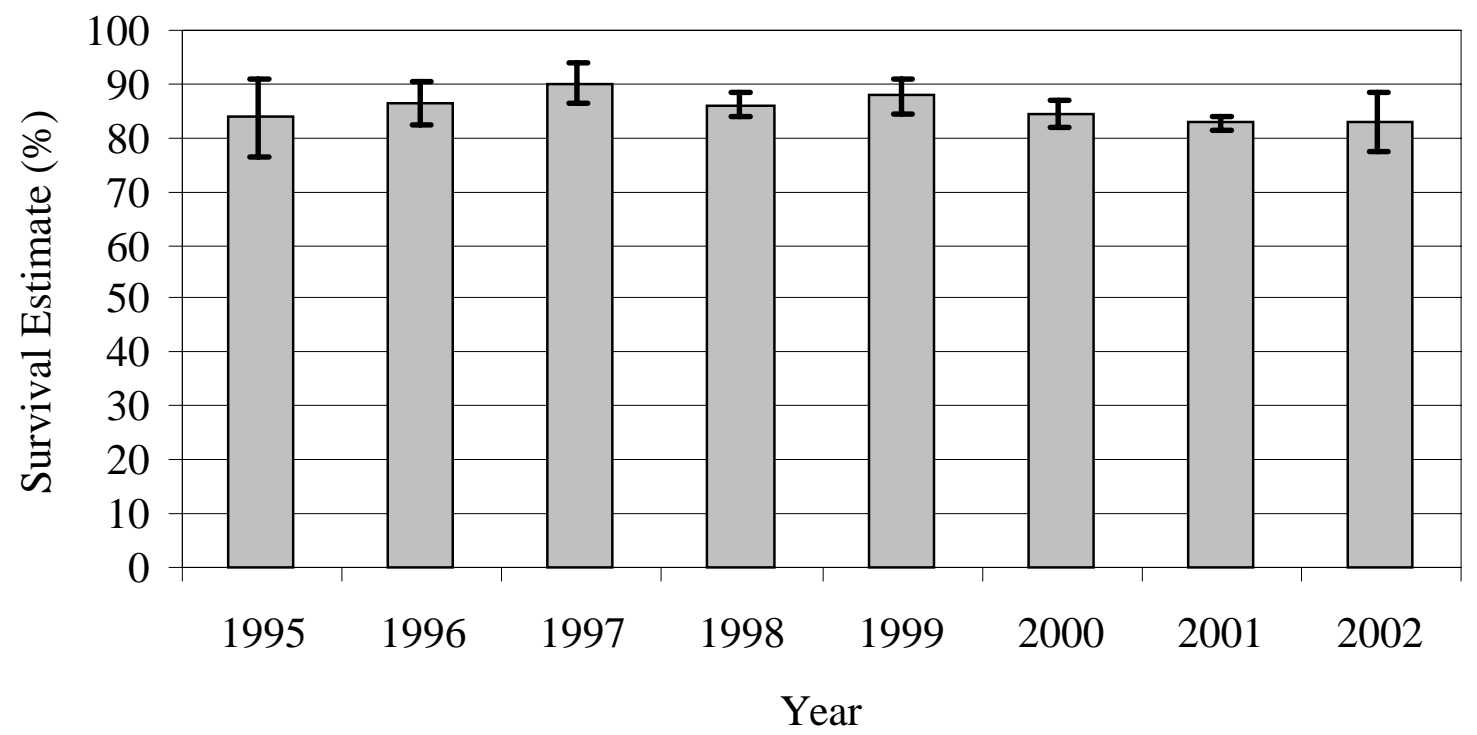

Figure 21. Season-wide survival estimates for natural steelhead released from the lower Imnaha River trap to Lower Granite Dam from 1995 to 2002. Error bars indicate 95\% confidence limits.

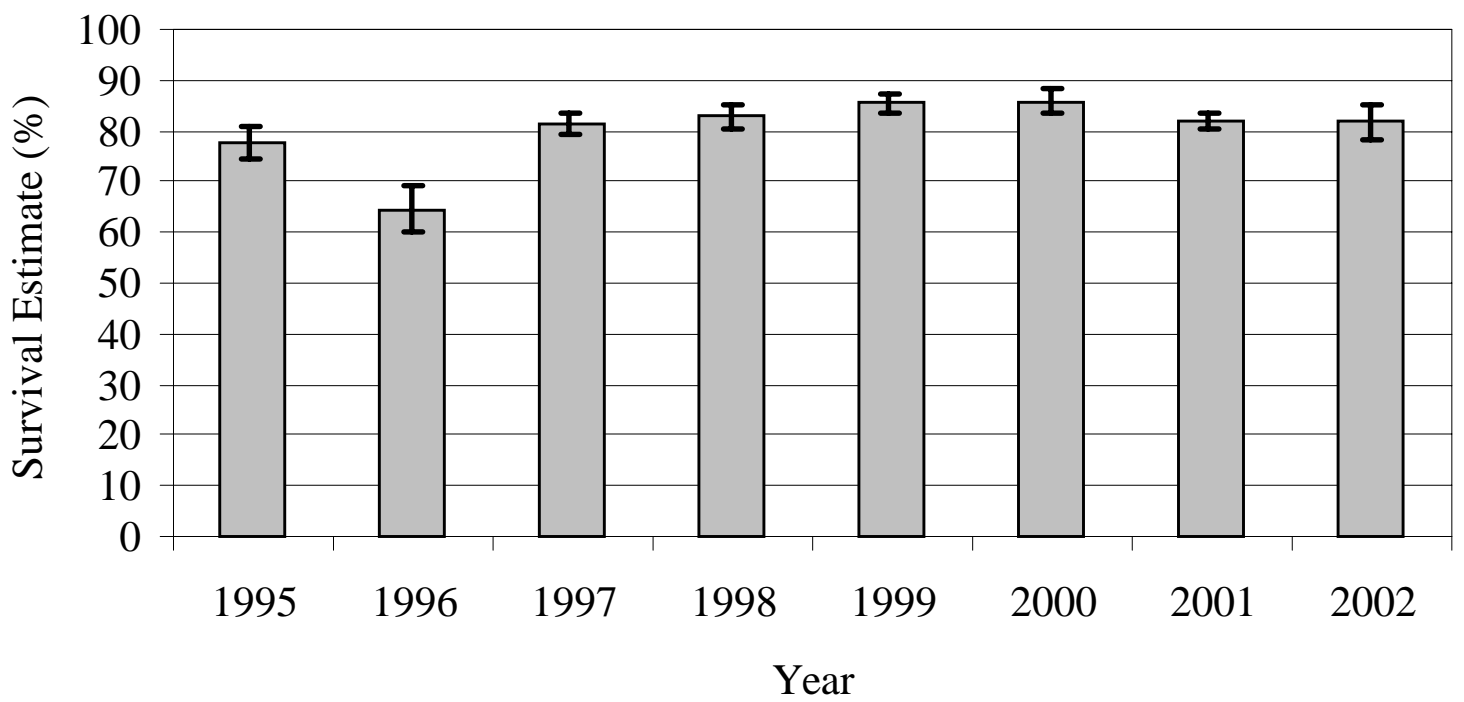

Figure 22. Season-wide survival estimates for hatchery steelhead released from the lower Imnaha River trap to Lower Granite Dam from 1995 to 2002. Error bars indicate 95\% confidence limits. 
Table 14. Season-wide estimates of survival from the lower Imnaha River trap to Lower Monumental Dam from 1997 to 2002. Ninety-five percent confidence intervals are shown in parentheses.

\begin{tabular}{ccccc}
$\begin{array}{c}\text { Migration } \\
\text { Year }\end{array}$ & $\begin{array}{c}\text { Natural Chinook } \\
\text { Salmon Survival } \\
(\%)\end{array}$ & $\begin{array}{c}\text { Hatchery Chinook } \\
\text { Salmon Survival } \\
(\%)\end{array}$ & $\begin{array}{c}\text { Natural Steelhead } \\
\text { Survival } \\
(\%)\end{array}$ & $\begin{array}{c}\text { Hatchery Steelhead } \\
\text { Survival } \\
(\%)\end{array}$ \\
\hline 1997 & & & $73.0(12.0)$ & $64.0(6.5)$ \\
1998 & $75.3(4.7)$ & $64.5(6.7)$ & $67.0(5.7)$ & $63.2(4.9)$ \\
1999 & $78.3(2.4)$ & $61.1(5.9)$ & $75.1(4.6)$ & $73.9(3.3)$ \\
2000 & $73.2(4.3)$ & $54.9(7.5)$ & $50.9(4.7)$ & $57.8(7.8)$ \\
2001 & $65.6(1.3)$ & $68.9(2.5)$ & $49.7(3.5)$ & $42.9(6.0)$ \\
2002 & $76.8(4.5)$ & $68.1(4.2)$ & $69.9(4.5)$ & $78.0(8.4)$ \\
\hline
\end{tabular}

28 release group to $75.8 \%( \pm 13.0 \%)$ for the April 21 release group in 2001. Natural steelhead weekly survival estimates ranged from $91.3 \%( \pm 24.2 \%)$ for the April 21 release group to $41.3 \%( \pm 19.4 \%)$ for the June 2 release group. The maximum weekly survival estimate for hatchery steelhead $(90.3 \% \pm 23.4 \%)$ was from the April 14 release. The lowest survival estimate from release to LMO was $61.5 \%( \pm 13.7 \%)$ resulting from the April 21 release group.

\section{Smolt to Adult Return Rates}

A SAR was calculated for two groups of PIT tagged juvenile natural chinook salmon emigrants from the Imnaha River, for brood years 1996 to 1998. The two groups were represented by: 1) juvenile chinook salmon pre-smolts PIT tagged during the fall, and 2) chinook salmon smolts PIT tagged during the spring. Estimated SAR's for these two groups represent in-river, or bypassed, migrating fish (although a few smolts were inadvertently diverted to the transportation system) defined as those fish that migrated by either spill or turbine routes. The estimated SAR provides a SAR index of in-river migrating Imnaha River chinook salmon. A season wide juvenile survival rate from the lower trap to LGR for the life stage and migration year of interest was used to generate comparable estimated smolt equivalents at LGR, which was then used to estimate SAR's from LGR to LGR. The LGR to LGR SAR was calculated because it provides a more comparable SAR rate given life stage differences.

The total number of chinook salmon adults detected at LGR for spring PIT tagged smolts from brood years 1996, 1997, and 1998 were 59, 105, and 109 fish, respectively (Table 17). Adult detections from fall PIT tagged pre-smolts from brood years 1996, 1997, and 1998 were 27, 20, and 22 fish, respectively. Adult detections from the fall tagged pre-smolts was below the desired sample size of 30 adults per brood year.

Natural chinook salmon pre-smolts had a higher LGR to LGR SAR index for all brood 
Table 15. Estimated survival probabilities for weekly PIT tag release groups of natural and hatchery chinook salmon and steelhead smolts released from the lower Imnaha River trap from February 22 to June 21, 2001 with 95\% confidence intervals in parentheses. Estimates are from release to the tail race for the trap to Lower Granite Dam and tail race to tail race for all other sites. Abbreviations: LGR -Lower Granite Dam, LGO - Little Goose Dam, LMO - Lower Monumental Dam.

\begin{tabular}{|c|c|c|c|c|c|}
\hline \multirow[b]{2}{*}{$\begin{array}{l}\text { Week of } \\
\text { Release }\end{array}$} & \multirow[b]{2}{*}{ Number Released } & \multicolumn{4}{|c|}{ Estimated Survival } \\
\hline & & $\begin{array}{l}\text { Trap to LGR \% } \\
\text { (95\% C.I). }\end{array}$ & $\begin{array}{l}\text { LGR to LGO \% } \\
\text { (95\% C.I.) }\end{array}$ & $\begin{array}{l}\text { LGO to LMO \% } \\
(95 \% \text { C.I. })\end{array}$ & $\begin{array}{c}\text { Trap to LMO \% } \\
\text { (95\%C.I.) }\end{array}$ \\
\hline \multicolumn{6}{|c|}{ Natural Chinook Salmon } \\
\hline $3 / 11$ & 403 & $83.8(3.8)$ & $98.0(4.3)$ & $84.4(8.2)$ & $69.0(6.9)$ \\
\hline $3 / 18$ & 3,462 & $84.0(1.3)$ & $95.5(1.4)$ & $84.1(1.4)$ & $67.5(2.3)$ \\
\hline $3 / 25$ & 1,755 & $83.2(1.9)$ & $93.8(2.0)$ & $85.4(3.4)$ & $66.7(3.0)$ \\
\hline $4 / 1$ & 810 & $85.8(2.6)$ & $94.3(2.5)$ & $86.1(2.4)$ & $69.6(4.3)$ \\
\hline $4 / 8$ & 580 & $88.8(2.9)$ & $93.1(3.4)$ & $85.1(5.4)$ & $70.3(4.9)$ \\
\hline $4 / 15$ & 1,166 & $90.0(2.0)$ & $94.1(2.4)$ & $84.1(4.1)$ & $71.2(3.7)$ \\
\hline $4 / 22$ & 816 & $89.2(2.5)$ & $91.1(3.2)$ & $82.7(4.9)$ & $67.2(4.3)$ \\
\hline $4 / 29$ & 313 & $76.2(5.0)$ & $95.3(5.1)$ & $69.9(8.7)$ & $50.8(6.9)$ \\
\hline $5 / 6$ & 253 & $76.4(5.7)$ & $92.2(6.7)$ & $79.7(11.6)$ & $56.1(8.8)$ \\
\hline \multicolumn{6}{|c|}{ Hatchery Chinook Salmon } \\
\hline $3 / 25$ & 602 & $74.7(3.7)$ & $95.1(4.1)$ & $85.4(7.2)$ & $60.7(5.6)$ \\
\hline $4 / 1$ & 1,136 & $80.2(2.5)$ & $96.4(2.7)$ & $90.3(4.9)$ & $69.8(4.1)$ \\
\hline $4 / 8$ & 297 & $78.9(5.0)$ & $96.9(5.0)$ & $90.9(8.7)$ & $69.5(7.5)$ \\
\hline $4 / 15$ & 493 & $87.5(3.4)$ & $98.0(3.6)$ & $91.1(6.7)$ & $78.2(6.0)$ \\
\hline $4 / 22$ & 369 & $82.2(4.5)$ & $91.1(4.6)$ & $93.9(7.1)$ & $70.3(6.5)$ \\
\hline \multicolumn{6}{|c|}{ Natural Steelhead } \\
\hline $4 / 15$ & 451 & $88.6(3.5)$ & $85.4(6.0)$ & $80.6(14.7)$ & $60.9(11.1)$ \\
\hline $4 / 22$ & 438 & $92.5(3.1)$ & $84.6(5.7)$ & $84.8(15.2)$ & $66.4(11.9)$ \\
\hline $4 / 29$ & 710 & $85.6(3.1)$ & $76.5(5.1)$ & $75.6(13.7)$ & $49.5(9.1)$ \\
\hline $5 / 6$ & 1,318 & $80.8(2.3)$ & $84.5(3.3)$ & $62.5(6.5)$ & $42.6(4.6)$ \\
\hline $5 / 13$ & 332 & $80.1(4.7)$ & $78.5(9.6)$ & $84.2(38.2)$ & $52.9(23.8)$ \\
\hline \multicolumn{6}{|c|}{ Hatchery Steelhead } \\
\hline $4 / 22$ & 610 & $87.1(3.3)$ & $75.0(6.7)$ & $59.0(11.4)$ & $38.5(7.3)$ \\
\hline $4 / 29$ & 601 & $79.1(3.9)$ & $68.8(9.9)$ & $70.1(25.9)$ & $38.1(13.5)$ \\
\hline $5 / 6$ & 1,313 & $83.0(2.4)$ & $78.4(7.8)$ & $79.1(22.6)$ & $51.5(14.0)$ \\
\hline $5 / 13$ & 500 & $85.6(4.5)$ & $80.9(16.2)$ & $57.5(30.9)$ & $39.8(20.0)$ \\
\hline
\end{tabular}


Table 16. Estimated survival probabilities for weekly PIT tag release groups of natural and hatchery chinook salmon and steelhead smolts released from the lower Imnaha River trap from March 4 to June 12, 2002 with 95\% confidence intervals in parentheses. Estimates are from release to the tail race for the trap to Lower Granite Dam and tail race to tail race for all other sites. Abbreviations: LGR -Lower Granite Dam, LGO - Little Goose Dam, LMO - Lower Monumental Dam.

\begin{tabular}{|c|c|c|c|c|c|}
\hline \multirow{2}{*}{$\begin{array}{l}\text { Week of } \\
\text { Release }\end{array}$} & \multirow{2}{*}{$\begin{array}{l}\text { Number } \\
\text { Released }\end{array}$} & \multicolumn{4}{|c|}{ Estimated Survival } \\
\hline & & $\begin{array}{c}\text { Trap to LGR \% } \\
(95 \% \text { C.I }) .\end{array}$ & $\begin{array}{c}\text { LGR to LGO } \\
\%\end{array}$ & $\begin{array}{c}\text { LGO to LMO \% } \\
(95 \% \text { C.I. })\end{array}$ & $\begin{array}{c}\text { Trap to LMO \% } \\
(95 \% \text { C.I. })\end{array}$ \\
\hline \multicolumn{6}{|c|}{ Natural Chinook Salmon } \\
\hline $3 / 24$ & 397 & $91.0(11.9$ & $81.1(12.7)$ & $105.7(14.4)$ & $78.0(10.0)$ \\
\hline $4 / 7$ & 252 & $99.0(12.6$ & $88.4(15.2)$ & $99.5(20.0)$ & $87.1(15.4)$ \\
\hline $4 / 14$ & 374 & $99.5(14.6$ & $87.4(16.4)$ & $96.6(17.5)$ & $84.0(12.5)$ \\
\hline $4 / 21$ & 428 & $79.4(8.2)$ & $95.2(12.6)$ & $108.8(18.4)$ & $82.2(12.4)$ \\
\hline $4 / 28$ & 436 & $79.1(9.9)$ & $103.1(18.3)$ & $81.6(15.7)$ & $66.6(9.5)$ \\
\hline \multicolumn{6}{|c|}{ Hatchery Chinook Salmon } \\
\hline $3 / 24$ & 470 & $70.2(12.5$ & $106.0(23.4)$ & $91.1(23.4)$ & $67.7(12.4)$ \\
\hline $3 / 31$ & 500 & $70.6(9.2)$ & $104.1(16.4)$ & $96.0(15.9)$ & $70.5(9.7)$ \\
\hline $4 / 7$ & 473 & $79.7(10.0$ & $103.2(18.7)$ & $80.6(15.5)$ & $66.3(9.2)$ \\
\hline $4 / 14$ & 531 & $72.4(11.2$ & $87.0(14.4)$ & $111.2(20.4)$ & $70.0(13.0)$ \\
\hline $4 / 21$ & 430 & $79.6(11.2$ & $86.0(14.4)$ & $110.8(20.4)$ & $75.8(13.0)$ \\
\hline $4 / 28$ & 392 & $86.4(14.6$ & $75.4(15.8)$ & $94.2(17.4)$ & $61.3(10.0)$ \\
\hline \multicolumn{6}{|c|}{ Natural Steelhead } \\
\hline $4 / 21$ & 299 & $98.4(24.5$ & $71.8(20.8)$ & $129.4(37.0)$ & $91.3(24.3)$ \\
\hline $4 / 28$ & 771 & $86.2(11.7$ & $83.9(19.6)$ & 86.5 (19.7) & $62.5(8.3)$ \\
\hline $5 / 5$ & 645 & $80.7(11.8$ & $86.9(17.5)$ & $105.2(25.4)$ & $73.7(15.0)$ \\
\hline $5 / 12$ & 1960 & $82.6(4.9)$ & $92.1(7.1)$ & $91.0(9.7)$ & $69.2(6.7)$ \\
\hline $5 / 26$ & 308 & $81.5(15.9$ & $96.0(25.3)$ & $92.0(33.2)$ & $71.9(22.8)$ \\
\hline $6 / 2$ & 231 & $82.8(18.3$ & $74.8(23.3)$ & $66.7(33.5)$ & $41.3(19.4)$ \\
\hline \multicolumn{6}{|c|}{ Hatchery Steelhead } \\
\hline $4 / 14$ & 300 & $84.4(10.9$ & $102.4(23.9)$ & $104.5(34.2)$ & $90.3(23.4)$ \\
\hline $4 / 21$ & 305 & $80.6(14.3$ & $100.0(27.9)$ & $76.3(23.6)$ & $61.5(13.7)$ \\
\hline $4 / 28$ & 309 & $96.5(24.8$ & $80.8(29.1)$ & $101.1(36.9)$ & $78.8(21.8)$ \\
\hline $5 / 5$ & 302 & $86.3(19.9$ & $89.5(22.7)$ & $115.9(44.9)$ & $89.5(29.0)$ \\
\hline $5 / 12$ & 300 & $120.6(40.1$ & $58.6(22.1)$ & $112.7(35.4)$ & $79.7(23.0)$ \\
\hline $5 / 19$ & 303 & $72.0(9.6)$ & $98.9(19.7)$ & $93.2(36.3)$ & $66.4(24.0)$ \\
\hline
\end{tabular}


years examined when compared to smolts (Table 17). The LGR to LGR SAR index for fall tagged pre-smolts ranged from $2.41 \%$ to $3.08 \%$. The LGR to LGR SAR index for spring tagged smolts ranged from $1.75 \%$ to $2.94 \%$ for the same brood years. The 1996 brood year pre-smolt SAR of 3.08\% appeared substantially different from the smolt SAR of $1.75 \%$. Observed differences between the 1997 and 1998 pre-smolt and smolt SAR indexes were relatively small (0.17\% - brood year 1997 and $0.04 \%$ - brood year 1998).

The observed SAR index for pre-smolt chinook salmon from the lower Imnaha River trap to LGR ranged from $1.00 \%$ to $1.86 \%$ for the three brood years examined (Table 17). The SAR index for smolts from the lower Imnaha River to LGR varied from $1.49 \%$ to $2.49 \%$.

Table 17. Detections of PIT tagged Imnaha River adult chinook salmon and smolt to adult return rates (SAR \%) from the lower Imnaha River trap to Lower Granite Dam (LGR) and from LGR to LGR for brood years 1996 to 1998.

\begin{tabular}{ccccccccccc}
\hline Life Stage & $\begin{array}{c}\text { Brood } \\
\text { Year }\end{array}$ & $\begin{array}{c}\text { Number } \\
\text { Tagged }\end{array}$ & $\begin{array}{c}\text { Estimated } \\
\text { Smolt } \\
\text { Equivalents }\end{array}$ & $\begin{array}{c}\text { Number of } \\
\text { Adult }\end{array}$ & \multicolumn{2}{c}{ Age at Return } & $\begin{array}{c}\text { Trap to } \\
\text { LGR } \\
\text { Detections }\end{array}$ & $\begin{array}{c}\text { LGR to } \\
\text { LGR } \\
\text { III }\end{array}$ & $\begin{array}{c}\text { IV } \\
\text { SAR } \\
(\%)\end{array}$ \\
\hline Pre-Smolt & 1996 & 1,453 & 878 & 27 & 5 & 15 & 7 & 1.86 & 3.08 \\
& 1997 & 2,000 & 830 & 20 & 3 & 16 & 1 & 1.00 & 2.41 \\
& 1998 & 2,009 & 739 & 22 & 2 & 12 & 8 & 1.10 & 2.98 \\
& 1996 & 3,956 & 3,370 & 59 & 3 & 41 & 15 & 1.49 & 1.75 \\
Smolt & 1997 & 5,306 & 4,696 & 105 & 8 & 69 & 28 & 1.98 & 2.24 \\
& 1998 & 4,369 & 3,705 & 109 & 3 & 62 & 44 & 2.49 & 2.94 \\
\hline
\end{tabular}




\section{$\underline{\text { Arrival Timing at Dams }}$}

Natural and Hatchery Chinook Salmon Arrival Timing

The three PIT tagged groups of natural chinook salmon during migration year 2001 had significantly different arrival times at LGR $(\mathrm{p}<0.05)$. Figure 23 shows the cumulative arrival frequency of natural chinook tagged at the upper trap and lower trap in the fall of 2000, and at the lower trap in the spring of 2001 at LGR. The April 26 median arrival date at LGR for natural chinook salmon from the lower trap in the fall was statistically different from the April 29 median arrival data for natural chinook salmon from the upper trap. The April 28 median arrival date for natural chinook salmon from the lower trap in the spring was also significantly different $(\mathrm{p}<0.05)$ than the median arrival date for fall tagged fish from the lower trap. A statistical comparison of the distributions using the Kolmogorov-Smirnov test (Statagraphics 1995, Steel et al.1997) also indicated that there was a statistical difference $(\mathrm{p}<0.05)$ in the arrival distributions at LGR for all three groups of natural chinook salmon in migration year 2001. Wilcoxon and Kolmogorov-Smirnov test results are presented in Appendix Tables F1 and F2. The range of arrival time, sample sizes, and median and $90 \%$ arrival times for natural chinook salmon presmolts are presented in Appendix F, Tables F3 and F4. The statistically significant differences in median arrival times and arrival distributions of natural chinook salmon at LGR during migration year 2001 are not significant from a water management point of view since no spill occurred at LGR from March to June of 2001. However, the Cormack Jolly-Seber survival estimate assumes PIT tag release groups are homogenous. Therefore, the statistical differences in arrival timing reinforce the need to estimate NPT Imnaha River natural chinook salmon by life stage and site.

PIT tagged migration year 2002 natural chinook salmon from the upper trap in the fall of 2001 also had significantly different median arrival times and distributions at LGR than natural chinook PIT tagged at the upper trap in the fall of 2001 and at the lower trap in the spring of 2002 ( $\mathrm{p}<0.05)$. The median arrival time at LGR during migration year 2002 of fall tagged fish from the upper and lower trap was May 5 and April 16, respectively (Figure 24). There was no statistically significant difference in the median arrival or distribution at LGR of fall tagged natural chinook salmon from the upper trap and spring tagged natural chinook salmon from the lower trap in 2002. The median arrival time for spring tagged natural chinook salmon smolts at LGR in migration year 2002 was May 5 (Appendix F, Table F5).

Spill at LGR encompassed the entire migration of fall tagged natural chinook salmon from the upper trap in 2002 (Figure 24). Their 90\% migration timing occurred during a spill of $27.5 \mathrm{Kcfs}$. Five percent of the fall tagged natural chinook salmon from the lower trap arrived at LGR prior to the beginning of spill on April 3. Ninety percent arrival timing for this group occurred during a spill of $23.7 \mathrm{kcfs}$. 


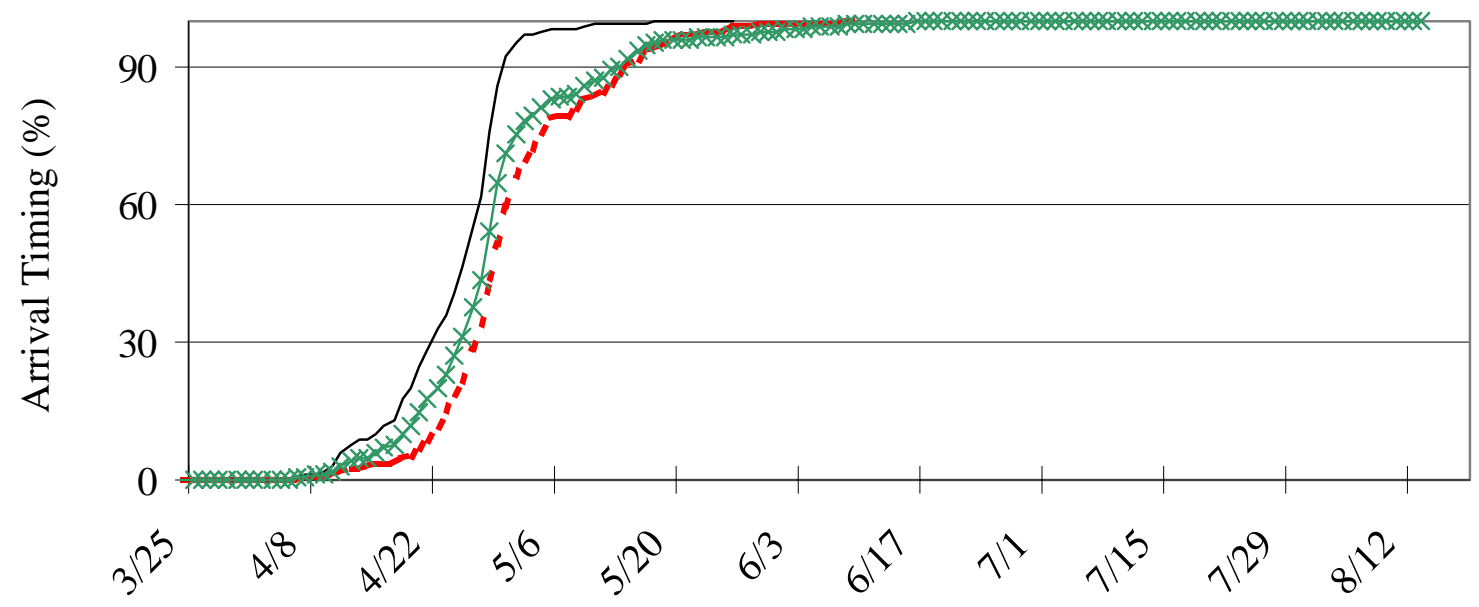

Date of Arrival at Lower Granite Dam

Figure 23. The arrival timing of natural chinook salmon tagged in the fall of 2000 at the upper and lower trap and in the spring of 2001 at the lower trap at Lower Granite Dam during migration year 2001.

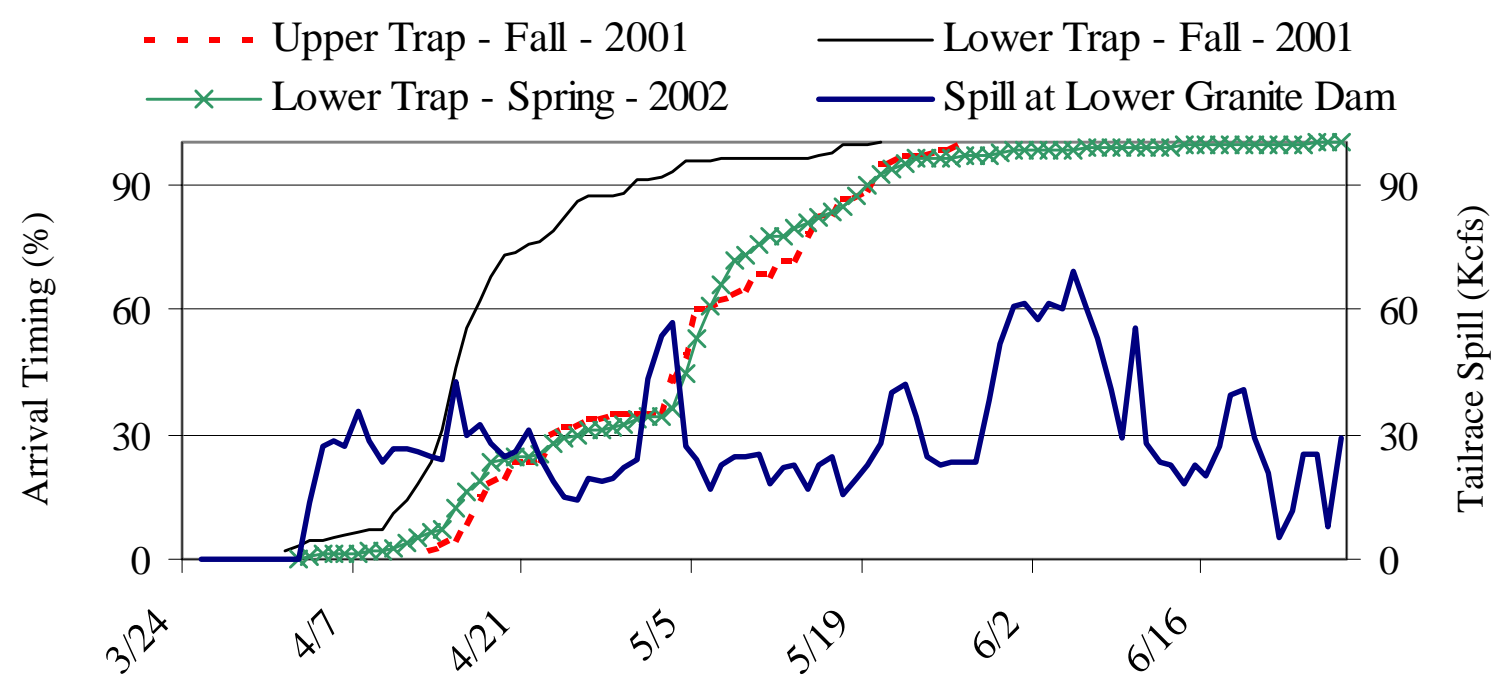

Date of Arrival at Lower Granite Dam

Figure 24. The arrival timing of natural chinook salmon tagged in the fall of 2001 at the upper and lower Imnaha River traps and natural chinook salmon tagged in the spring of 2002 at the lower trap at Lower Granite Dam in relation to the 2002 spill at Lower Granite Dam. 
Ninety percent arrival timing at LGR during migration year 2001 for the three groups of natural chinook salmon occurred on the following dates: May 14 - upper trap (fall), April 30 lower trap (fall), and May 12 (spring). Migration year $200290 \%$ arrival timing at LGR for the three groups of natural chinook salmon occurred on the following dates: May 20 - upper trap (fall), May 30 - lower trap (fall), and May 20 (spring) (Appendix F3 and F4).

Natural chinook salmon median arrival at LGO in migration years 2001 and 2002 occurred on May 7 for fall tagged fish from the upper site. Fall tagged natural chinook salmon from the lower site had median arrival dates at LGO of April 30 and May 1 for migration years 2001 and 2002, respectively. Spring tagged fish had median arrival dates at LGO of May 2 and May 7 for migration years 2001 and 2002 respectively. The $90 \%$ arrival timing in 2001 at LGO occurred on the following dates: May 18 - upper trap, May 11 - lower trap (fall), and May 17 lower trap (spring). The $90 \%$ arrival timing in 2002 at LGO occurred on the following dates: May 22 - upper trap, May 5 - lower trap (fall), and May 23 lower trap (spring).

Imnaha River 2001 spring tagged natural chinook salmon arrived at LGR from March 30 to August 13 (Appendix Table F5). They were observed at LGO from April 16 to July 23. At LMO they were first observed on April 28, with median arrival occurring on May 13 and $90 \%$ arrival occurring on May 20. They were last seen at LMO on July 18. Forty-five fish from this group were observed at MCN from April 29 to June 5. The spring tagged natural chinook salmon for migration year 2002 arrived at LGR from April 2 to June 27. The range of arrival timing at LGO, LMO, and MCN occurred during the following dates: April 15 to June 20 at LGO, April 22 to June 14 at LMO, and April 23 to June 10 at MCN. Median arrivals occurred on May 7 at LGO, May 13 at LMO, and May 14 at MCN. Ninety percent arrival dates were as follows: May 23 at LGO, May 22 at LMO, and May 23 at MCN.

Fall tagged natural chinook salmon from the upper Imnaha River trap have been observed at LGR as early as April 3 (1998) to as late as June 9 (2001) from 1998 to 2002. The May 5 median arrival timing and the May $2090 \%$ arrival date at LGR were later than usual. The median arrival dates at LGR, from 1998 to 2001, ranges from April 27 to May 5. The 90\% arrival timing (1998 to 2001) had ranged from May 9 to May 20. Median arrival times at LGO for 2001 and 2002 were within the April 30 to May 28 range of median observations made from 1998 to 2000 . The $200290 \%$ arrival timing at LGO of May 22 was the latest observation of it's kind for this group since 1998. The prior range of $90 \%$ arrivals at LGO occurred from May 11 (2000) to May 18 (1999, 2001).

First observations of fall tagged natural chinook salmon from the lower trap have ranged from March 27 (1998) to April 4 (2000). Last observations for this group have occurred from May 2 (1999) to May 26 (2001). The 2001 median arrival data at LGR of April 26 was the lastest observed at LGR since 1998 and the 2002 90\% arrival data at MCN was the latest observed at LGR since 1998. At LGO the first arrivals for 2001 (April 23) and 2002 (April 13) were later than first observations of April 8 (1999) to April 12 (2000) from 1998 to 2000. The last observations made for this group at LGO in 2001 and 2002 (June 16, 2001 and May 16, 
2002) were later than the observations of May 9 (1999) to May $12(1998,2000)$ at LGO from 1998 to 2000. The median arrival dates at LGO for this group in 2001 were later than the April 17 (2000) to April 25 (1998) arrival date range from 1998 to 2000 and the $90 \%$ arrival dates in 2002 were also later than previous observations of April 24 (2000) to May 2 (1998) of 90\% arrival timing at LGO for fall tagged natural chinook salmon from the lower trap.

NPT has monitored the first, median, 90\%, and last arrival time for chinook salmon since 1992 (Appendix F). The median arrival time is useful for comparing migration timing (McConnaha et al. 1985). The 90\% arrival time is commonly used for management decisions. NPT has used the first and last arrival to define the range of arrival timing at LGR, LGO, LMO, and MCN.

Hatchery chinook salmon smolt arrival timing from 1992 to 2002 is presented in Appendix Table F6. This arrival data quantifies the period of time that survival estimates in the previous section represent. The ranges of the 2001 hatchery chinook salmon arrival dates are as follows: March 31 to May 27 at LGR, April 15 to May 29 at LGO, April 27 to June 4 at LMO, and May 5 to May 31 at MCN. Median arrivals occurred on April 29 at LGR, May 7 at LGO, and May 12 at LMO. Ninety percent arrivals occurred May 10 at LGR, May 16 at LGO, and May 25 at LMO during migration year 2001. Arrivals of Imnaha River hatchery chinook salmon migrating in 2002 were observed from April 1 to May 23 at LGR, April 13 to June 1 at LGO, April 30 to June 11 at LMO, and April 16 to June 10 at MCN. Median arrivals occurred at LGR on May 7, at LGO on May 12, at LMO on May 14, and at MCN on May 15 (2002). The $90 \%$ date of arrival at each dam is as follows: May 19 at LGR, May 22 at LGO, May 23 at LMO, and May 25 at MCN during migration year 2002. Spill at LGR almost encompassed the entire period of hatchery chinook salmon during migration year 2002; $1.3 \%$ passed prior to the start of spill (Figure 25).

\section{$\underline{\text { Natural and Hatchery Steelhead Arrival Timing }}$}

Natural steelhead arrived at LGR from March 29 to September 9 during the 2001 migration year (Appendix Table F7). The range of arrival timing at LGO for 2001 occurred from April 7 to August 19. At LMO the first arrival occurred on May 6. The last interrogation of an Imnaha River natural steelhead at LMO occurred October 3. Arrivals at MCN ranged from May 16 to August 5. Median dates of arrival occurred at LGR on May 14 and at LGO on May 16. The 2001 90\% arrival timing for natural steelhead occurred May 18 at LGR and May 24 at LGO. The range of 2002 arrivals of Imnaha River natural steelhead were as follows: April 10 to June 26 at LGR, April 13 to August 28 at LGO, April 30 to August 8 at LMO, and April 29 to June 7 at MCN. Median arrival occurred on May 18 at LGR, May 21 at LGO, May 22 at LMO, and May 22 at MCN (2002). Ninety percent arrivals for migration year 2002 occurred on May 31 at LGR, June 2 at LGO, June 3 at LMO, and May 27 at MCN. Spill at median arrival at LGR was $19.5 \mathrm{kcfs}$ for natural steelhead (Figure 25). 


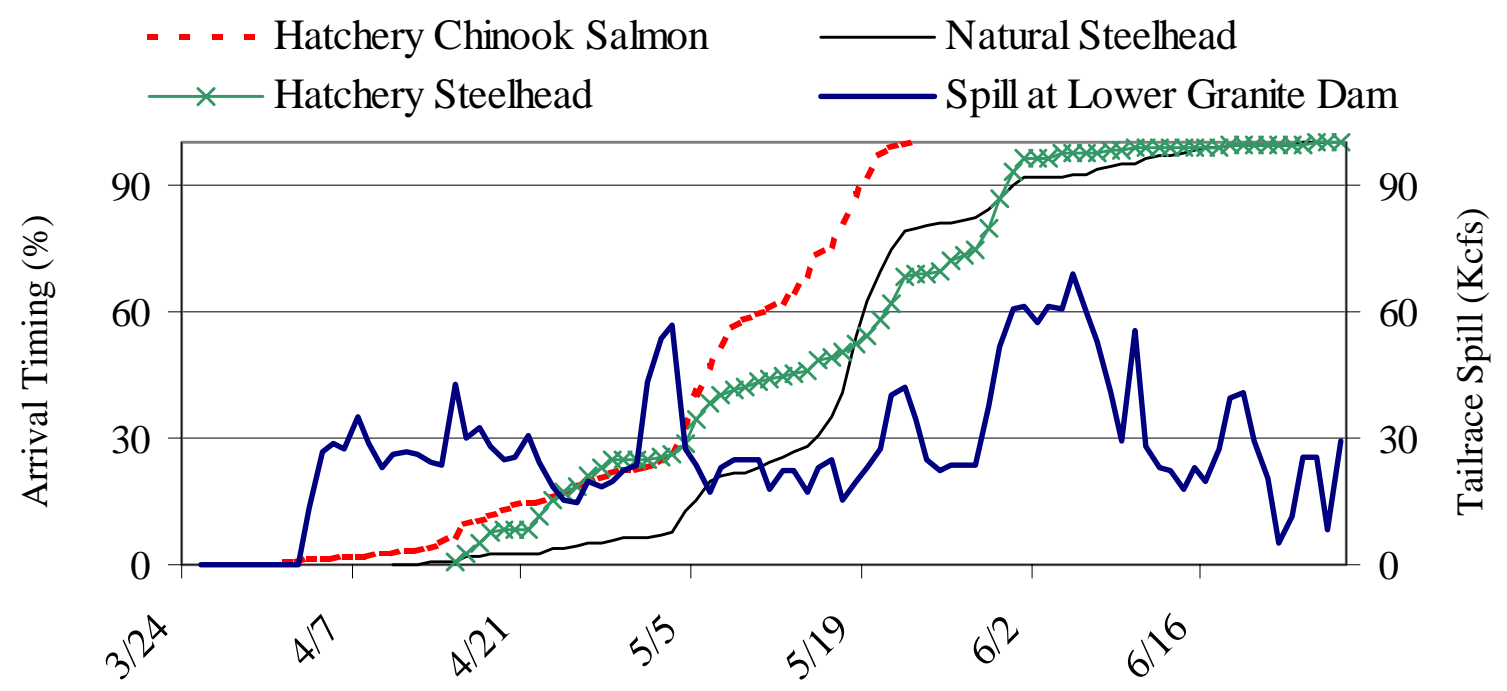

Date of Arrival at Lower Granite Dam

Figure 25. The arrival timing of hatchery chinook salmon and natural and hatchery steelhead tagged in the spring of 2002 at the lower trap, at Lower Granite Dam, in relation to the 2002 spill at Lower Granite Dam.

Imnaha River hatchery steelhead smolt arrival timing for migration years 1993 to 2002 at LGR, LGO, LMO, and MCN is presented in Appendix Table F8. Imnaha River hatchery steelhead smolts migrating in 2001 arrived at LGR from April 21 to September 23, at LGO from April 28 to October 30, at LMO from May 8 to October 25, and at MCN from May 21 to July 4, 2001. They had median arrivals of May 16 at LGR and May 20 at LGO. Ninety percent arrival timing occurred May 26 at LGR, and June 21 at LGO.

Imnaha River hatchery steelhead arrivals at LGR, LGO, LMO, and MCN for the 2002 migration year occurred from April 15 to June 27 at LGR, from April 19 to June 29 at LGO, from April 30 to October 18 at LMO, and from May 2 to June 16 at MCN. Median dates of arrival were May 17 at LGR, May 24 at LGO, May 28 at LMO, and May 25 at MCN. The 90\% arrivals occurred on May 31 at LGR, June 3 at LGO, June 9 at LMO, and June 6 at MCN. Spill at median arrival at LGR was $15.5 \mathrm{kcfs}$ for hatchery steelhead.

\section{Travel Time to Lower Granite Dam}

Natural chinook salmon weekly median travel times to LGR from March 18, and April 1 to April 22, for the 2001 migration year were significantly faster than hatchery chinook salmon (p $<0.05)$ (Table 18). Natural and hatchery chinook salmon median travel times from releases occurring from the weeks of March 25 to April 22 decreased with an increase in date. A 
Table 18. A summary of average and median annual and weekly travel times of natural and hatchery chinook salmon released from the lower Imnaha screw trap, February 22 to June 21, 2001, at Lower Granite Dam (LGR). Weeks with less than 30 interrogations at Lower Granite Dam were not presented. Wilcoxon rank sum statistical test values represent a comparison of median natural and hatchery smolt travel times.

\begin{tabular}{|c|c|c|c|c|c|c|}
\hline \multirow{2}{*}{$\begin{array}{l}\text { Migration } \\
\text { Year }\end{array}$} & \multirow{2}{*}{$\begin{array}{l}\text { Week } \\
\text { Released }\end{array}$} & \multicolumn{2}{|c|}{ Number Interrogated } & \multicolumn{2}{|c|}{$\begin{array}{c}\text { Median Travel Time } \\
\text { (days) }\end{array}$} & \multirow[b]{2}{*}{$\mathrm{p}$ value } \\
\hline & & Natural & Hatchery & Natural & Hatchery & \\
\hline \multirow[t]{11}{*}{2001} & $3 / 11$ & 272 & & 40.1 & & \\
\hline & $3 / 18$ & 2,408 & 54 & 33.7 & 27.4 & 0.00 \\
\hline & $3 / 25$ & 1,204 & 341 & 29.8 & 29.9 & 0.13 \\
\hline & $4 / 1$ & 566 & 662 & 24.8 & 25.7 & 0.00 \\
\hline & $4 / 8$ & 426 & 171 & 16.5 & 20.2 & 0.00 \\
\hline & $4 / 15$ & 821 & 283 & 11.1 & 12.7 & 0.00 \\
\hline & $4 / 22$ & 580 & 213 & 9.1 & 11.9 & 0.00 \\
\hline & $4 / 29$ & 190 & & 11.7 & & \\
\hline & $5 / 6$ & 150 & & 6.3 & & \\
\hline & $5 / 13$ & 33 & & 10.3 & & \\
\hline & $5 / 20$ & 77 & & 8.3 & & \\
\hline \multirow[t]{5}{*}{2002} & $3 / 24$ & 81 & 49 & 21.5 & 24.1 & 0.26 \\
\hline & $3 / 31$ & 37 & 57 & 15.4 & 24.8 & 0.00 \\
\hline & $4 / 14$ & 71 & 77 & 16.0 & 26.0 & 0.00 \\
\hline & $4 / 21$ & 95 & 74 & 12.1 & 18.1 & 0.00 \\
\hline & $4 / 28$ & 82 & 77 & 9.5 & 14.3 & 0.00 \\
\hline
\end{tabular}

commonly accepted explanation for this trend is that the rate of smoltification is increasing due to increasing water temperatures (Berggren and Filardo 1993, and Smith et al. 2002). Natural chinook salmon median travel times ranged from 6.3 days to 40.1 days, while hatchery chinook salmon median travel times ranged from 11.9 days to 29.9 days.

Median travel times to LGR for natural chinook salmon migrating in the 2002 migration year were significantly faster $(\mathrm{p}<0.05)$ than median travel times of hatchery chinook salmon released during the weeks of March 31 to April 28 (Table 18). Median travel times for natural and hatchery chinook salmon decreased from April 14 to April 28. Natural chinook salmon median travel time ranged from 9.5 days (April 28) to 21.5 days (March 24). Median weekly travel time for hatchery chinook salmon ranged from 14.3 days (April 28) to 26.0 days (April 14).

Natural steelhead median travel times to LGR during the 2001 migration year were 
significantly faster $(\mathrm{p}<0.05)$ than hatchery steelhead for weekly release groups from April 15 to May 13 (Table 19). Median weekly travel times for natural steelhead decreased from the weeks of March 18 (53.6 days) to April 22 (5.6 days). Hatchery steelhead median travel times had no distinct pattern and ranged from 4.8 days for the May 20 release group to 13.7 days for the April 29 release group.

Natural steelhead median travel times to LGR during the 2002 migration year were significantly faster $(\mathrm{p}<0.05)$ than hatchery steelhead for weekly release groups from April 28 to May 19 (Table 19). There was no obvious relationship between release date and travel time to LGR for natural or hatchery steelhead in 2002. Median weekly travel times for natural steelhead ranged from three days (May 26) to 10.6 days (April 21). Hatchery steelhead weekly mean travel times ranged from 2.9 days (May 26) to 13.7 days (April 21).

\section{Mortality}

Trapping and PIT tagging caused 68 (2.94\%), and one $(0.04 \%)$ mortalities during the fall of 2000 at the upper trap (Appendix Table G1). At the lower trap trapping and PIT tagging caused seven $(0.23 \%)$ and one $(0.03 \%)$ mortalities during the fall of 2000 (Appendix Table G2). Forty four natural chinook salmon mortalities occurred at the lower trap during the spring of 2001; 23 due to trapping, two due to handling, and 19 due to PIT tagging (Appendix Table G3). Due to the large catch of natural chinook salmon $(n=10,663)$ the overall percentage of mortality for natural chinook salmon was low $(0.41 \%)$. Twenty one hatchery chinook salmon mortalities occurred as a result of trapping $(n=15)$ and handling $(n=6)$ at the lower trap during the spring of 2001 ( $0.13 \%$ overall mortality). The five natural steelhead and four hatchery steelhead mortalities that occurred during the spring of 2001 were due to trapping (Appendix Table G3).

Trapping, handling, and PIT tagging caused 19, one, and three natural chinook salmon mortalities during the fall of 2001 at the upper trap for an overall mortality rate of $1.63 \%$ (Appendix Table G4). At the lower trap, trapping and PIT tagging caused one, and two mortalities during the fall of 2001 for an overall mortality rate of $0.14 \%$ (Appendix Table G5). A total of 14 natural chinook salmon mortalities occurred at the lower trap during the spring of 2002; seven due to trapping, two due to handling, and five due to PIT tagging (Appendix Table G6). Overall mortality rates for natural chinook salmon captured in the spring of 2002 were $0.52 \%$. Fourteen hatchery chinook salmon mortalities occurred due to trapping $(\mathrm{n}=11)$ and PIT tagging $(n=3)$ in the spring of 2002. This resulted in an overall mortality rate of $0.05 \%$. Five natural steelhead and 11 hatchery steelhead mortalities occurred at the lower trap in the spring of 2002. All steelhead mortalities were due to trapping. This mortality was 0.07 for natural steelhead and $0.04 \%$ for hatchery steelhead.

\section{Incidental Catch}

The incidental catch during the fall and spring of migration year 2001 total 1,369 fish. It was comprised of five families of fishes: Salmonidae, Centrarchidae, Catostomidae, Cyprinidae, 
Table 19. A summary of average and median annual and weekly travel times of natural and hatchery steelhead released from the lower Imnaha screw trap, March 4 to June 12, 2002, at Lower Granite Dam (LGR). Weeks with less than 30 interrogations at Lower Granite Dam were not presented. Wilcoxon rank sum statistical test values represent a comparison of median natural and hatchery smolt travel times.

\begin{tabular}{|c|c|c|c|c|c|c|}
\hline \multirow{2}{*}{$\begin{array}{l}\text { Migration } \\
\text { Year }\end{array}$} & \multirow{2}{*}{$\begin{array}{c}\text { Week } \\
\text { Released }\end{array}$} & \multicolumn{2}{|c|}{ Number Interrogated } & \multicolumn{2}{|c|}{$\begin{array}{c}\text { Median Travel Time } \\
\text { (days) }\end{array}$} & \multirow[b]{2}{*}{$\mathrm{p}<$ value } \\
\hline & & Natural & Hatchery & Natural & Hatchery & \\
\hline \multirow[t]{9}{*}{2001} & $3 / 18$ & 44 & & 53.6 & & \\
\hline & $3 / 25$ & 52 & & 44.2 & & \\
\hline & $4 / 8$ & 33 & & 15.1 & & \\
\hline & $4 / 15$ & 342 & 109 & 8.7 & 13.6 & 0.00 \\
\hline & $4 / 22$ & 358 & 476 & 5.6 & 8.0 & 0.00 \\
\hline & $4 / 29$ & 537 & 434 & 10.1 & 13.7 & 0.00 \\
\hline & $5 / 6$ & 969 & 1,009 & 5.5 & 6.6 & 0.00 \\
\hline & $5 / 13$ & 249 & 369 & 4.3 & 5.1 & 0.00 \\
\hline & $5 / 20$ & 95 & 141 & 5.0 & 4.8 & 0.88 \\
\hline \multirow[t]{9}{*}{2002} & $4 / 7$ & 41 & & 5.5 & & \\
\hline & $4 / 14$ & 52 & 86 & 8.9 & 5.5 & 0.09 \\
\hline & $4 / 21$ & 41 & 61 & 10.6 & 13.7 & 0.75 \\
\hline & $4 / 28$ & 147 & 47 & 4.9 & 7.3 & 0.00 \\
\hline & $5 / 5$ & 107 & 44 & 7.4 & 12.1 & 0.00 \\
\hline & $5 / 12$ & 419 & 40 & 4.5 & 5.2 & 0.03 \\
\hline & $5 / 19$ & 55 & 83 & 6.7 & 7.2 & 0.04 \\
\hline & $5 / 26$ & 51 & 39 & 3.0 & 2.9 & 0.62 \\
\hline & $6 / 2$ & 59 & & 5.0 & & \\
\hline
\end{tabular}

and Cottidae (Appendix Table H1). The catch of Salmonidae consisted of 123 juvenile rainbow/steelhead, 27 adult natural and hatchery steelhead, 482 mountain whitefish (Prosopium williamsoni), and 94 bull trout (Salvelinus confluentus). The juvenile rainbow/steelhead reported for the 2001 and 2002 incidental catch were either resident fish or not actively migrating and are not a subset of the catch of natural steelhead in Tables 2 and 3 of this report. Twenty-five Centrarchidae were captured and comprised solely of smallmouth bass (Micropterus dolomieui). A total of 200 bridgelip suckers (Catostomus columbianus), 30 largescale suckers (Catostomus macrocheilus), and four unidentified sucker species represented the family Catostomidae. The catch of Cyprinidae was as follows: 191 longnose dace (Rhinichthys cataractae), 21 redside shiner (Richardsonius balteatus), 55 northern pike minnow (Ptychocheilus oregonensis), 13 chislemouth (Acrocheilus alutaceus), and 24 speckled dace (Rhinichthys osculus). A total of 88 
Cottus species (sculpins) of the family Cottidae were captured during the spring study period.

The incidental catch during the fall and spring of migration year 2002 total 2,842 fish. It was comprised of six families of fishes: Salmonidae, Centrarchidae, Catostomidae, Cyprinidae, Cottidae, and Ictaluridae (Appendix Table H2). One adult chinook salmon was captured in the lower trap during the spring of 2002. The remaining catch of Salmonidae consisted of 728 juvenile rainbow trout/steelhead, 91 adult natural and hatchery steelhead, 300 mountain whitefish, and 151 bull trout. The catch of Centrarchidae consisted of 139 smallmouth bass and two bluegill (Lepomis macrochirus). A total of 52 bridgelip suckers, 815 largescale suckers, and 178 unidentified sucker species represented the family Catostomidae. The catch of Cyprinidae was as follows: 217 longnose dace, 28 redsided shiner, 52 northern pikeminnow, 27 chislemouth, six speckled dace, and one Leopard Dace (Rhinichthys falcatus). A total of 47 Cottus species (sculpins) of the family Cottidae and seven bullhead, representing the family Ictaluridae were captured during migration year 2002.

\section{ACKNOWLEDGMENTS}

The Nez Perce Tribe extends the administrative support necessary to complete these projects and this report. Project funding from the U.S. Fish and Wildlife Service's Lower Snake River Compensation Plan program initiated the Imnaha River emigration project investigations in 1992 and continues today. Project cost share funding is also provided by the Bonneville Power Administration through the Imnaha Smolt Monitoring Program. We wish to thank Joe McCormack, for his years of expertise in operating, maintaining, and repairing the trapping equipment and PIT tagging fish at the lower and upper trapping site. We thank our Office Manager, Jody Conner, for provided help during the volitional release of hatchery chinook salmon and our Research Coordinator, Jay Hesse, for advice and logistical support. Thank you's are also due to the following technicians that endured a variety of trapping and living conditions to provide this data: Mike Busby, Levi Carson, Jason Crenshaw, Steve Deal, George Growing Thunder, David Kane, Neal Meshell, Rich Miller, Levi Pinkham, Jason Shull, Robert Tuell, Olicutt Watters, Jaime Williams, and Manuel Villalobos. Oregon Department of Fish and Wildlife PIT tagged and released the hatchery chinook salmon from the acclimation facility. We extend our gratitude to the United States Forest Service for allowing us the use of the Thorn Creek guard station facilities and Jack McClaren for allowing us access to his land for trapping purposes. The Fish Passage Center's Data System Administrative Manager, Henry Franzoni, and Senior Data Analyst, Sergie Rasskazov provided customized software for collecting, transferring, and storing data. Thank you's are also due to Carter Stein and Dave Marvin of the Pacific States Marine Fisheries Commission for providing technical support. 


\section{LITERATURE CITED}

Anonymous a. 2003. USGS/Cascade Volcano Observatory. [online] Available at http://vulcan.wr.usgs.gov/volcanoes/washington/columbia_river/discription_ columbia_river.html.

Anonymous b. 2003. Walla Walla District Hydropower Dams [online] Available at http://www.usace.army.mil/

Anonymous. 2000. 13292000-IMNAHA RIVER AT IMNAHA, OR. [online] Available at http://oregon.usgs.gov/rt-cgi/gen_stn_pg?station=13292000. February 24.

Anonymous. 2001. Weekly Report \#01-4. Fish Passage Center. 2501 SW First Ave., Suite 230, Portland, Oregon 97201.

Ashe, B. L., A. C. Miller, P. A. Kucera, and M. L. Blenden. 1995. Spring Outmigration Of Wild and hatchery Chinook Salmon and Steelhead Smolts From The Imnaha River, March 1 June15, 1994. FPC Technical Report. NPT DFRM Lapwai, Idaho

Bagenal, T. B., and F. W. Tesch. 1978. Age and growth. Pages 101-136 in T.B.Bagenal, editor. Methods for assessment of fish production in fresh waters, 3rd edition. Blackwell Scientific Publications, Oxford, England.

Berggren, T.J., and M.J. Filardo. 1993. An Analysis of Variables in Influencing the Migration of Juvenile Salmonids in the Columbia River Basin. North American Journal of Fisheries Management 13:48-63.

Blenden, M.L., P.A. Kucera, and E.R. Veach. 1998. Spring Emigration of Natural and Hatchery Chinook Salmon and Steelhead Smolts from the Imnaha River, Oregon, February 25 June 27, 1997. Bonneville Power Administration Technical Report. Contract DE-FC7988FC38906. Project 87-127. NPT DFRM, Lapwai, ID.

Bryson, D., C. Rabe, A. Davidson, and D. Saul. 2001. Draft Imnaha Subbasin Summary. Northwest Power Planning Council.

Burnham, K.P., D.R. Anderson, G.C. White, C. Brownie, and K.H. Pollock. 1987. Design and Analysis Methods for Fish Survival Experiments Based on Release-Recapture. American Fisheries Society, Bethesda, Maryland.

Carmichal, R.W., S.J. Parker, and T. A. Whitesel. 1998. Status Review of the Chinook Salmon Hatchery Program in the Imnaha Basin, Oregon. Lower Snake River Compensation Plan Status Review Symposium. USFWS Lower Snake River Compensation Plan Office. Boise, Idaho. pp. 119-140. 
Cleary, P.J., M.L. Blenden, and P.A. Kucera. 2000. Emigration of Natural and Hatchery Chinook Salmon from the Imnaha River, Oregon October 14, 1997 to June16, 1998. Bonneville Power Administration Technical Report. Contract \#97AM30423.

Cleary, P.J., M.L. Blenden, and P.A. Kucera. 2002. Emigration of Natural and Hatchery Chinook Salmon from the Imnaha River, Oregon October 19, 1998 to June 24, 1999. Bonneville Power Administration Technical Report. Contract \# 97AM30423.

Cleary, P.J., P.A. Kucera., M.L. Blenden, and K. Gillogly. 2003. Emigration of Natural and Hatchery Chinook Salmon from the Imnaha River, Oregon October 20, 1999 to June 15, 2000.Bonneville Power Administration Techincal Report. Contract \# 97AM30423.

Eddy, D. 2002. [personal communication].

Efron, B. and R. Tibshirani. 1986. Bootstrap methods for standard errors, confidence intervals, and other measures of statistical accuracy. Statistical Science 1:54 -77.

Groot, C., L. Margolis, and W.C. Clarke. 1995. Physiological Ecology of Pacific Salmon. UBC Press. Vancouver, BC. pp 469- 478.

James, G. 1984. Imnaha River basin recommended salmon and steelhead habitat improvement measures. Working paper. Confederated Tribes of the Umatilla Indian Reservation.

Kennen, J. G., S. J. Wisniewski, N. H. Ringler, and H. M. Hawkins. 1994. Application and modification of an auger trap to quantify emigrating fishes in Lake Ontario tributaries. North American Journal of Fisheries Management 14:828-836.

Kucera, P. A. 1989. Nez Perce Tribal review of the Imnaha River Lower Snake River Compensation Plan. Working paper. LSRCP Technical Report AFF1/LSR-89-08. Nez Perce tribe Fisheries Management, Lapwai, Idaho.

Kucera, P.A., and M.L. Blenden. 1998. Emigration of Hatchery and Natural Chinook Salmon From the Imnaha River. Lower Snake River Compensation Plan Status Review Symposium. USFWS Lower Snake River Compensation Plan Office. Boise, Idaho. pp.141-153.

Matthews, G. M., J. R. Harmon, S. Achord, O. W. Johnson, and L. A. Kubin. 1990. Evaluation of transportation... on the Columbia and Snake Rivers, 1989. Report to the U.S. Army Corps of Engineers, Contract DACW68-84-H0034. NMFS. Seattle, Washington. 
Matthews, G. M., S. Accord, J. R. Harmon, O. W. Johnson, D. M. Marsh, B. P. Sandford, N. N. Paasch, K. W. McIntyre, and K. L. Thomas. 1992. Evaluation of transportation of juvenile salmonids...Columbia and Snake Rivers, 1990.Report to USACE, Seattle, Washington

McConnaha, W.E., L.R. Basham, and J. Jordan. 1985. Migration Characteristics of Columbia Basin Salmon and Steelhead Trout, 1984. Part II:1984 Smolt Monitoring Program Annual Report. Water Budget Center. Portland, Oregon.

National Marine Fisheries Service. 2000. Endangered Species Act - Section 7 Consultation Biological Opinion: Reiteration of consultation on operation of the Federal Columbia River Power System, including the Juvenile Fish Transportation Program, and 19 Bureau of Reclamation projects in the Columbia Basin. National Marine Fisheries Service, Northwest Region. December 2000.

Oregon Dept. of Fish and Wildlife. 2002 a. Lower Snake River Fish and Wildlife Compensation Plan Grande Ronde and Imnaha Basins Annual Operation Plan: February 1, 2002 January 31, 2003. p. 23.

Oregon Dept. of Fish and Wildlife.2002 b. Hatchery and Genetic Management Plan, Imnaha / Snake River / Columbia Basin / Oregon, December 20, 2002.

Ott, L. 1984. An introduction to statistical methods and data analysis. PWS Publishers. Boston, Massachusetts.

Patterson, S. 2003. [personal communication].

Prentice, E. F., D. L. Park, T. A. Flagg, and S. McCutcheon. 1986. A study to determine the biological feasibility of a new fish tagging system, 1985-1986. Report to the Bonneville Power Administration. Contract DE-A179-83BP11982, Project 83-119. NMFS

Prentice, E. F., T. A. Flagg, C. S. McCutcheon, D. F. Brastow, and D. C. Cross. 1990. Equipment, methods, and an automated data-entry station for PIT tagging. American Fisheries Society Symposium 7:335-340.

Smith, S.G., J.R. Skalski, J.W. Schlechte, A. Hoffmann, and V. Cassen, J.R. 1994. Statistical Survival Analysis of Fish and Wildlife Tagging Studies. Contract DE-BI79-90BP02341. Project 89-107. Bonneville Power Administration. Portland, Oregon.

Smith, S.G., W.D. Muir, J.G. Williams, and J.R. Skalski. 2002 . Factors Associated with Travel Time and Survival of Migrant Yearling Chinook Salmon and Steelhead in the Lower Snake River. North American Journal of Fisheries Management. 22:385 - 405.

Steel, R.G.D., J.H. Torrie, D.A. Dicky. 1997. Principles and Procedures of Statistics: A Biometrical Aproach. Third Edition. McGraw-Hill, Inc. New York, New York.

Statgraphics Plus. 1995. Statgraphics Plus Version 2. Manugistics, Inc. Rockville, Maryland. 
Thedinga, J. F., M. L. Murphy, S. W. Johnson, J. M. Lorenz, and K. V. Koski. 1994. Determination of salmonid smolt yield with rotary screw traps in the Situk River, Alaska, to predict effects of glacial flooding. North American J.F.M. 14:837-851.

Westhagen, P. and J. Skalski, 1997. The Design and Analysis of Salmonid Tagging Studies in the Columbia Basin. Bonneville Power Administration. Contract DE-BI79-90BP02341. Project 89-107-00. Portland, Oregon.

Whitesel, T.A., R.W. Carmichael, M.W. Flesher, D.L. Eddy. 1998. Summer Steelhead in the Imnaha River Basin, Oregon. Lower Snake River Compensation Plan Status Review Symposium. USFWS Lower Snake River Compensation Plan Office. Boise, Idaho. pp. $32-42$. 
APPENDIX A

IMNAHA AND SNAKE RIVER DISCHARGE

A - 1 
Appendix A. Table A1. The mean daily discharge for the Imnaha River gauge 13292000 from October 14 to November 24, 1928 to 2001, and October 14 to November 24, 2000 and 2001.

\begin{tabular}{|c|c|c|c|}
\hline Date & 1928 to 2001 & 2000 & 2001 \\
\hline 14-Oct & 166 & 158 & 127 \\
\hline 15-Oct & 163 & 161 & 123 \\
\hline 16-Oct & 167 & 159 & 119 \\
\hline 17-Oct & 160 & 155 & 115 \\
\hline 18-Oct & 156 & 152 & 114 \\
\hline 19-Oct & 156 & 153 & 113 \\
\hline 20-Oct & 154 & 151 & 114 \\
\hline 21-Oct & 154 & 173 & 114 \\
\hline 22-Oct & 158 & 166 & 116 \\
\hline 23-Oct & 161 & 155 & 142 \\
\hline 24-Oct & 161 & 154 & 151 \\
\hline 25-Oct & 162 & 152 & 132 \\
\hline 26-Oct & 168 & 151 & 128 \\
\hline 27-Oct & 165 & 198 & 125 \\
\hline 28-Oct & 166 & 189 & 125 \\
\hline 29-Oct & 171 & 258 & 128 \\
\hline 30-Oct & 172 & 214 & 133 \\
\hline 31-Oct & 170 & 192 & 270 \\
\hline 1-Nov & 169 & 180 & 207 \\
\hline 2-Nov & 166 & 172 & 169 \\
\hline 3-Nov & 165 & 167 & 150 \\
\hline 4-Nov & 170 & 171 & 139 \\
\hline 5-Nov & 170 & 173 & 133 \\
\hline 6-Nov & 170 & 169 & \\
\hline 7-Nov & 173 & 160 & \\
\hline 8-Nov & 174 & 165 & 115 \\
\hline 9-Nov & 173 & 168 & 115 \\
\hline 10-Nov & 176 & 162 & 114 \\
\hline 11-Nov & 191 & 157 & 113 \\
\hline 12-Nov & 208 & 136 & 112 \\
\hline 13-Nov & 195 & 143 & 113 \\
\hline 14-Nov & 190 & 161 & 118 \\
\hline $15-\mathrm{Nov}$ & 189 & 166 & 122 \\
\hline 16-Nov & 193 & 131 & 118 \\
\hline 17-Nov & 198 & 120 & 116 \\
\hline 18-Nov & 195 & 128 & 117 \\
\hline 19-Nov & 198 & 132 & 114 \\
\hline 20-Nov & 199 & 147 & 113 \\
\hline 21-Nov & 190 & 145 & 138 \\
\hline 22-Nov & 183 & 144 & 147 \\
\hline 23-Nov & 183 & 129 & 147 \\
\hline 24-Nov & 193 & 178 & 129 \\
\hline
\end{tabular}

A - 2 
Appendix A. Table A2. The mean daily discharge for the Imnaha River gauge 13292000 from 1928 to 2001 and 2002, and the mean daily discharge for the Snake River gauge 13334300 from 1958 to 2001 and 2002 for the month of March.

\begin{tabular}{|c|c|c|c|c|c|c|}
\hline \multicolumn{4}{|c|}{$\begin{array}{c}\text { Imnaha River Gauge } 13292000 \\
\text { Mean Daily Discharge (cfs) }\end{array}$} & \multicolumn{3}{|c|}{$\begin{array}{c}\text { Snake River Gauge } 13334300 \\
\text { Mean Daily Discharge (cfs) }\end{array}$} \\
\hline Date & 1928 to 2001 & 2001 & 2002 & 1958 to 2001 & 2001 & 2002 \\
\hline 1-Mar & 310 & 126 & 158 & 37,620 & 13,800 & 17,600 \\
\hline 2-Mar & 317 & 160 & 147 & 36,690 & 13,500 & 17,800 \\
\hline 3-Mar & 313 & 133 & 145 & 37,040 & 16,900 & 16,300 \\
\hline 4-Mar & 304 & 142 & 164 & 36,640 & 16,100 & 17,500 \\
\hline 5-Mar & 304 & 143 & 167 & 35,300 & 14,300 & 17,800 \\
\hline 6-Mar & 305 & 147 & 163 & 36,330 & 14,900 & 14,599 \\
\hline 7-Mar & 309 & 153 & 169 & 36,710 & 17,100 & 15,100 \\
\hline 8-Mar & 318 & 175 & 135 & 36,960 & 16,800 & 18,300 \\
\hline 9-Mar & 325 & 204 & 156 & 37,590 & 18,200 & 17,300 \\
\hline 10-Mar & 354 & 202 & 157 & 38,050 & 18,000 & 15,300 \\
\hline 11-Mar & 380 & 193 & 154 & 38,170 & 15,800 & 19,300 \\
\hline 12-Mar & 374 & 187 & 173 & 39,090 & 16,500 & 23,800 \\
\hline 13-Mar & 383 & 187 & 174 & 39,390 & 19,300 & 24,400 \\
\hline 14-Mar & 386 & 198 & 173 & 39,660 & 21,500 & 25,000 \\
\hline 15-Mar & 383 & 197 & 173 & 40,060 & 21,300 & 24,800 \\
\hline 16-Mar & 391 & 201 & & 39,680 & 23,800 & 20,400 \\
\hline 17-Mar & 404 & 192 & & 40,780 & 20,100 & 18,900 \\
\hline 18-Mar & 412 & 188 & & 40,910 & 17,200 & 19,900 \\
\hline 19-Mar & 422 & 218 & 183 & 41,280 & 16,600 & 25,200 \\
\hline 20-Mar & 438 & 295 & 178 & 41,580 & 23,000 & 22,000 \\
\hline 21-Mar & 459 & 291 & 177 & 41,990 & 25,000 & 19,900 \\
\hline 22-Mar & 466 & 295 & 196 & 42,220 & 24,400 & 19,600 \\
\hline 23-Mar & 483 & 316 & 273 & 41,790 & 20,800 & 21,900 \\
\hline 24-Mar & 503 & 361 & 378 & 42,930 & 21,200 & 23,800 \\
\hline 25-Mar & 504 & 412 & 360 & 43,250 & 19,800 & 32,500 \\
\hline 26-Mar & 519 & 432 & 369 & 43,060 & 22,500 & 37,700 \\
\hline 27-Mar & 537 & 384 & 431 & 43,640 & 28,700 & 39,200 \\
\hline 28-Mar & 551 & 350 & 460 & 44,430 & 29,100 & 39,600 \\
\hline 29-Mar & 553 & 331 & 459 & 44,280 & 28,800 & 39,800 \\
\hline 30-Mar & 563 & 316 & 459 & 43,780 & 29,400 & 38,100 \\
\hline 31-Mar & 575 & 308 & 516 & 43,730 & 26,900 & 41,200 \\
\hline $\begin{array}{l}\text { Monthly } \\
\text { Average }\end{array}$ & 414 & 240 & 245 & 40,149 & 20,365 & 24,019 \\
\hline
\end{tabular}

A - 3 
Appendix A. Table A3. The mean daily discharge for the Imnaha River gauge 13292000 from 1928 to 2001 and 2002, and the mean daily discharge for the Snake River gauge 13334300 from 1958 to 2001 and 2002 for the month of April.

\begin{tabular}{ccccccc}
\hline & \multicolumn{2}{c}{ Imnaha River Gauge 13292000} & \multicolumn{3}{c}{ Snake River Gauge 13334300} \\
Mean Daily Discharge (cfs)
\end{tabular}


Appendix A. Table A4. The mean daily discharge for the Imnaha River gauge 13292000 from 1928 to 2001 and 2002, and the mean daily discharge for the Snake River gauge 13334300 from 1958 to 2001 and 2002 for the month of May.

\begin{tabular}{|c|c|c|c|c|c|c|}
\hline \multirow[b]{2}{*}{ Date } & \multicolumn{3}{|c|}{$\begin{array}{c}\text { Imnaha River Gauge } 13292000 \\
\text { Mean Daily Discharge (cfs) }\end{array}$} & \multicolumn{3}{|c|}{$\begin{array}{c}\text { Snake River Gauge } 13334300 \\
\text { Mean Daily Discharge (cfs) }\end{array}$} \\
\hline & 1928 to 2001 & 2001 & 2002 & 1958 to 2001 & 2001 & 2002 \\
\hline 1-May & 1,285 & 848 & 1,280 & 55,550 & 37,900 & 30,600 \\
\hline 2-May & 1,308 & 738 & 1,419 & 56,289 & 34,600 & 33,000 \\
\hline 3-May & 1,339 & 668 & 1,510 & 56,480 & 31,400 & 40,300 \\
\hline 4-May & 1,385 & 629 & 1,390 & 57,210 & 30,600 & 41,100 \\
\hline 5-May & 1,392 & 639 & 1,350 & 57,999 & 31,000 & 36,200 \\
\hline 6-May & 1,408 & 620 & 1,210 & 58,809 & 27,600 & 36,500 \\
\hline 7-May & 1,469 & 597 & 1,120 & 59,940 & 28,200 & 39,500 \\
\hline 8-May & 1,502 & 624 & 1,010 & 60,629 & 30,300 & 35,500 \\
\hline 9-May & 1,512 & 686 & 921 & 62,060 & 31,300 & 32,600 \\
\hline 10-May & 1,512 & 664 & 847 & 63,370 & 31,900 & 30,200 \\
\hline 11-May & 1,524 & 667 & 804 & 63,740 & 34,000 & 28,899 \\
\hline 12-May & 1,548 & 723 & 856 & 63,730 & 34,700 & 27,000 \\
\hline 13-May & 1,571 & 828 & 1,019 & 63,810 & 36,200 & 27,100 \\
\hline 14-May & 1,574 & 865 & & 65,140 & 41,500 & 33,400 \\
\hline 15-May & 1,595 & 1,150 & & 66,970 & 48,200 & 34,500 \\
\hline 16-May & 1,595 & 1,030 & & 68,200 & 54,200 & 36,500 \\
\hline 17-May & 1,608 & 879 & & 68,950 & 58,000 & 36,300 \\
\hline 18-May & 1,617 & 791 & & 69,930 & 54,900 & 37,500 \\
\hline 19-May & 1,633 & 765 & & 70,590 & 52,100 & 41,800 \\
\hline 20-May & 1,649 & 717 & & 70,020 & 46,600 & 54,700 \\
\hline 21-May & 1,648 & 669 & & 69,890 & 40,100 & 63,800 \\
\hline 22-May & 1,649 & 669 & & 70,600 & 40,300 & 63,500 \\
\hline 23-May & 1,690 & 706 & & 71,500 & 40,400 & 61,300 \\
\hline 24-May & 1,686 & 804 & 1,110 & 71,990 & 41,100 & 59,300 \\
\hline 25-May & 1,678 & 895 & 1,110 & 73,070 & 42,700 & 52,100 \\
\hline 26-May & 1,729 & 893 & 1,170 & 74,010 & 44,600 & 45,700 \\
\hline 27-May & 1,717 & 831 & 1,330 & 76,090 & 40,000 & 49,400 \\
\hline 28-May & 1,676 & 882 & 1,510 & 76,700 & 39,600 & 60,100 \\
\hline 29-May & 1,638 & 757 & 1,750 & 77,020 & 43,300 & 63,900 \\
\hline 30-May & 1,616 & 641 & 1,960 & 78,610 & 37,900 & 74,800 \\
\hline 31-May & 1,580 & 597 & 1,790 & 78,510 & 35,200 & 84,200 \\
\hline \multicolumn{7}{|l|}{ Monthly } \\
\hline Average & 1,559 & 757 & 1,260 & 67,013 & 39,368 & 44,881 \\
\hline
\end{tabular}

A - 5 
Appendix A. Table A5. The mean daily discharge for the Imnaha River gauge 13292000 from 1928 to 2001 and 2002, and the mean daily discharge for the Snake River gauge 13334300 from 1958 to 2001 and 2002 for the month of June.

\begin{tabular}{|c|c|c|c|c|c|c|}
\hline \multicolumn{4}{|c|}{$\begin{array}{c}\text { Imnaha River Gauge } 13292000 \\
\text { Mean Daily Discharge (cfs) }\end{array}$} & \multicolumn{3}{|c|}{$\begin{array}{c}\text { Snake River Gauge } 13334300 \\
\text { Mean Daily Discharge (cfs) }\end{array}$} \\
\hline Date & 1928 to 2001 & 2001 & 2002 & 1958 to 2001 & 2001 & 2002 \\
\hline 1-Jun & 1,554 & 602 & & 78,330 & 36,000 & 83,200 \\
\hline 2-Jun & 1,531 & 629 & 1,540 & 77,670 & 29,000 & 81,100 \\
\hline 3-Jun & 1,529 & 555 & 1,450 & 77,890 & 27,400 & 80,600 \\
\hline 4-Jun & 1,502 & 486 & 1,409 & 78,710 & 26,400 & 76,900 \\
\hline 5-Jun & 1,509 & 457 & 1,440 & 80,330 & 25,800 & 71,000 \\
\hline 6-Jun & 1,525 & 447 & 1,490 & 82,060 & 25,000 & 67,400 \\
\hline 7-Jun & 1,523 & 410 & 1,380 & 81,830 & 26,400 & 65,500 \\
\hline 8-Jun & 1,502 & 396 & 1,210 & 81,120 & 29,500 & 62,000 \\
\hline 9-Jun & 1,482 & 404 & 1,070 & 79,720 & 29,600 & 58,199 \\
\hline 10-Jun & 1,432 & 419 & 989 & 78,010 & 23,400 & 54,600 \\
\hline 11-Jun & 1,394 & 407 & 920 & 76,740 & 23,200 & 50,200 \\
\hline 12-Jun & 1,398 & 442 & 898 & 76,550 & 23,200 & 46,700 \\
\hline 13-Jun & 1,401 & 404 & 932 & 76,660 & 23,300 & 44,100 \\
\hline 14-Jun & 1,378 & 375 & & 75,920 & 23,100 & 42,600 \\
\hline 15-Jun & 1,371 & 354 & & 75,590 & 22,900 & 43,700 \\
\hline 16-Jun & 1,383 & 346 & 1,340 & 75,340 & 24,500 & 47,300 \\
\hline 17-Jun & 1,341 & 343 & 1,400 & 75,080 & 20,300 & 50,300 \\
\hline 18-Jun & 1,305 & 335 & 1,370 & 74,250 & 20,400 & 50,500 \\
\hline 19-Jun & 1,290 & 323 & 1,210 & 73,260 & 20,100 & 52,700 \\
\hline 20-Jun & 1,271 & 317 & 1,070 & 71,920 & 18,800 & 47,900 \\
\hline 21-Jun & 1,240 & 316 & 1,050 & 70,150 & 20,400 & 44,500 \\
\hline 22-Jun & 1,211 & 323 & 1,030 & 68,240 & 18,100 & 42,100 \\
\hline 23-Jun & 1,172 & 322 & 1,070 & 65,680 & 17,700 & 43,100 \\
\hline 24-Jun & 1,137 & 313 & 1,060 & 63,770 & 16,900 & 43,200 \\
\hline 25-Jun & 1,109 & 299 & 1,130 & 61,790 & 16,800 & 46,500 \\
\hline 26-Jun & 1,082 & 279 & 1,170 & 60,480 & 16,700 & 41,700 \\
\hline 27-Jun & 1,049 & 289 & 1,180 & 59,170 & 16,500 & 41,200 \\
\hline 28-Jun & 1,007 & 334 & 1,140 & 56,940 & 16,700 & 42,500 \\
\hline 29-Jun & 980 & 290 & 1,130 & 54,479 & 17,500 & 38,900 \\
\hline 30-Jun & 945 & 270 & 1,000 & 52,080 & 16,800 & 35,300 \\
\hline \multicolumn{7}{|l|}{ Monthly } \\
\hline Average & 1,318 & 383 & 1,188 & 71,992 & 22,413 & 53,183 \\
\hline
\end{tabular}


Appendix A. Table A6. Average monthly discharge for the Imnaha River from 1929 to 2002 at USGS Gauge 13292000, and for the Snake River from 1959 to 2002 at USGS gauge 13334300.

\begin{tabular}{|c|c|c|c|c|c|c|c|c|}
\hline \multirow[b]{2}{*}{ Year } & \multicolumn{4}{|c|}{ Imnaha River } & \multicolumn{4}{|c|}{ Snake River } \\
\hline & March & April & May & June & March & April & May & June \\
\hline 1929 & 340 & 656 & 1,245 & 1,207 & & & & \\
\hline 1930 & 294 & 753 & 724 & 705 & & & & \\
\hline 1931 & 218 & 582 & 881 & 433 & & & & \\
\hline 1932 & 306 & 1,052 & 2,169 & 1,349 & & & & \\
\hline 1933 & 191 & 754 & 1,383 & 2,187 & & & & \\
\hline 1934 & 478 & 813 & 699 & 439 & & & & \\
\hline 1935 & 177 & 758 & 1,243 & 1,034 & & & & \\
\hline 1936 & 204 & 973 & 1,151 & 597 & & & & \\
\hline 1937 & 194 & 476 & 1,200 & 838 & & & & \\
\hline 1938 & 574 & 1,578 & 2,602 & 2,123 & & & & \\
\hline 1939 & 506 & 795 & 967 & 510 & & & & \\
\hline 1940 & 579 & 1,146 & 1,133 & 823 & & & & \\
\hline 1941 & 546 & 921 & 1,363 & 1,532 & & & & \\
\hline 1942 & 337 & 1,608 & 1,748 & 1,408 & & & & \\
\hline 1943 & 415 & 1,567 & 1,323 & 1,451 & & & & \\
\hline 1944 & 162 & 671 & 867 & 968 & & & & \\
\hline 1945 & 276 & 727 & 1,661 & 1,579 & & & & \\
\hline 1946 & 390 & 1,273 & 1,807 & 1,229 & & & & \\
\hline 1947 & 475 & 824 & 1,398 & 933 & & & & \\
\hline 1948 & 254 & 1,241 & 2,804 & 2,339 & & & & \\
\hline 1949 & 416 & 1,049 & 1,666 & 930 & & & & \\
\hline 1950 & 326 & 725 & 1,307 & 1,542 & & & & \\
\hline 1951 & 303 & 1,147 & 1,515 & 972 & & & & \\
\hline 1952 & 244 & 1,532 & 2,421 & 1,753 & & & & \\
\hline 1953 & 330 & 943 & 1,544 & 1,881 & & & & \\
\hline 1954 & 363 & 884 & 1,349 & 1,026 & & & & \\
\hline 1955 & 141 & 512 & 1,505 & 1,386 & & & & \\
\hline 1956 & 642 & 1,760 & 2,381 & 1,796 & & & & \\
\hline 1957 & 475 & 815 & 2,661 & 1,394 & & & & \\
\hline 1958 & 372 & 928 & 2,552 & 2,004 & & & & \\
\hline 1959 & 307 & 989 & 1,482 & 1,550 & 26,150 & 38,080 & 45,170 & 68,620 \\
\hline 1960 & 500 & 923 & 1,316 & 1,094 & 31,990 & 41,700 & 53,050 & 61,850 \\
\hline 1961 & 395 & 635 & 1,355 & 1,329 & 28,030 & 26,850 & 42,510 & 54,250 \\
\hline 1962 & 287 & 1,192 & 1,336 & 1,371 & 26,390 & 49,480 & 55,730 & 60,800 \\
\hline
\end{tabular}


Appendix A. Table A6. Continued.

\begin{tabular}{|c|c|c|c|c|c|c|c|c|}
\hline \multirow[b]{2}{*}{ Year } & \multicolumn{4}{|c|}{ Imnaha River } & \multicolumn{4}{|c|}{$\underline{\text { Snake River }}$} \\
\hline & March & April & May & June & March & April & May & June \\
\hline 1963 & 408 & 891 & 1,561 & 1,291 & 23,800 & 28,640 & 64,420 & 83,850 \\
\hline 1964 & 165 & 719 & 1,525 & 1,752 & 23,250 & 38,190 & 65,369 & 98,320 \\
\hline 1965 & 419 & 1,426 & 1,845 & 1,791 & 54,870 & 71,080 & 93,730 & 102,400 \\
\hline 1966 & 414 & 952 & 1,210 & 786 & 25,870 & 29,770 & 37,050 & 34,060 \\
\hline 1967 & 377 & 533 & 1,990 & 2,132 & 23,600 & 23,760 & 56,789 & 87,320 \\
\hline 1968 & 464 & 570 & 1,283 & 1,258 & 25,840 & 27,050 & 38,440 & 56,620 \\
\hline 1969 & 351 & 1,492 & 2,083 & 1,491 & 48,410 & 74,380 & 86,150 & 59,460 \\
\hline 1970 & 309 & 384 & 1,820 & 1,715 & 28,740 & 31,090 & 70,330 & 96,840 \\
\hline 1971 & 378 & 1,068 & 2,777 & 1,965 & 52,430 & 82,970 & 117,200 & 116,900 \\
\hline 1972 & 869 & 758 & 1,708 & 1,673 & 90,400 & 67,300 & 81,060 & 98,400 \\
\hline 1973 & 255 & 517 & 1,148 & 767 & 28,310 & 26,179 & 42,060 & 38,530 \\
\hline 1974 & 761 & 1,264 & 1,876 & 2,612 & 59,350 & 88,700 & 90,500 & 132,700 \\
\hline 1975 & 272 & 557 & 2,249 & 2,284 & 43,870 & 60,929 & 85,360 & 100,800 \\
\hline 1976 & 242 & 839 & 1,734 & 921 & 43,200 & 78,290 & 102,200 & 77,860 \\
\hline 1977 & 114 & 345 & 445 & 423 & 18,680 & 18,880 & 20,610 & 24,380 \\
\hline 1978 & 729 & 1,611 & 1,528 & 1,306 & 39,330 & 55,379 & 67,670 & 70,000 \\
\hline 1979 & 437 & 681 & 1,802 & 912 & 38,290 & 40,140 & 56,899 & 44,080 \\
\hline 1980 & 307 & 1,049 & 1,602 & 1,496 & 25,820 & 40,100 & 75,480 & 75,730 \\
\hline 1981 & 393 & 888 & 1,501 & 1,397 & 26,500 & 32,880 & 58,660 & 75,340 \\
\hline 1982 & 699 & 1,117 & 2,116 & 2,044 & 65,740 & 73,680 & 97,820 & 110,700 \\
\hline 1983 & 970 & 1,007 & 1,933 & 1,710 & 77,140 & 64,080 & 97,250 & 106,600 \\
\hline 1984 & 504 & 1,046 & 1,839 & 1,949 & 60,270 & 86,710 & 118,700 & 134,200 \\
\hline 1985 & 282 & 1,078 & 1,285 & 1,157 & 36,080 & 63,280 & 57,550 & 48,920 \\
\hline 1986 & 993 & 981 & 1,361 & 1,329 & 90,330 & 77,470 & 80,640 & 93,230 \\
\hline 1987 & 518 & 704 & 764 & 417 & 24,820 & 27,430 & 38,620 & 21,210 \\
\hline 1988 & 246 & 646 & 707 & 713 & 19,810 & 25,890 & 40,320 & 32,500 \\
\hline 1989 & 510 & 961 & 1,099 & 1,014 & 40,740 & 58,460 & 51,800 & 44,630 \\
\hline 1990 & 401 & 1,084 & 965 & 1,159 & 23,230 & 30,400 & 38,270 & 45,260 \\
\hline 1991 & 228 & 531 & 1,177 & 914 & 18,910 & 19,840 & 45,160 & 48,240 \\
\hline 1992 & 371 & 451 & 571 & 361 & 21,950 & 24,460 & 32,570 & 16,850 \\
\hline 1993 & 432 & 871 & 2,172 & 1,510 & 37,920 & 49,890 & 86,760 & 77,750 \\
\hline 1994 & 320 & 771 & 1,003 & 613 & 22,880 & 31,310 & 44,270 & 24,850 \\
\hline 1995 & 1,026 & 1,149 & 2,197 & 1,759 & 36,540 & 41,510 & 78,030 & 92,740 \\
\hline 1996 & 618 & 1,345 & 1,648 & 1,396 & 71,970 & 84,250 & 82,110 & 105,800 \\
\hline 1997 & 657 & 1,398 & 2,038 & 1,681 & 77,640 & 85,020 & 109,600 & 117,800 \\
\hline
\end{tabular}

A -8 
Appendix A. Table A6. Continued.

\begin{tabular}{|c|c|c|c|c|c|c|c|c|}
\hline \multirow[b]{2}{*}{ Year } & \multicolumn{4}{|c|}{ Imnaha River } & \multicolumn{4}{|c|}{ Snake River } \\
\hline & March & April & May & June & March & April & May & June \\
\hline 1998 & 582 & 940 & 2,500 & 1,661 & 40,040 & 49,040 & 105,900 & 90,590 \\
\hline 1999 & 606 & 1,066 & 1,997 & 1,801 & 68,600 & 67,530 & 76,880 & 99,650 \\
\hline 2000 & 358 & 1,247 & 1,245 & 989 & 38,290 & 56,210 & 53,600 & 42,620 \\
\hline 2001 & 240 & 438 & 757 & 383 & 20,365 & 23,727 & 39,368 & 22,413 \\
\hline 2002 & 245 & 1,005 & 1,260 & 1,188 & 24,019 & 39,466 & 44,881 & 53,183 \\
\hline
\end{tabular}




\section{APPENDIX B \\ IMNAHA AND SNAKE RIVER TEMPERATURE DATA FOR MIGRATION YEARS \\ 2001 AND 2002}

B - 1 
Appendix B. Table B1. Mean daily water temperature for the Imnaha River from October 15 to November 20, 2000 and from October 14 to November 24, 2001 at the lower Imnaha River trap.

\begin{tabular}{|c|c|c|}
\hline Date & 2000 & 2001 \\
\hline 14-Oct & & 11.7 \\
\hline 15-Oct & 10.5 & 10.2 \\
\hline 16-Oct & 10.9 & 10.6 \\
\hline 17-Oct & 11.0 & 10.9 \\
\hline 18 -Oct & 11.0 & 8.5 \\
\hline 19-Oct & 12.0 & 9.6 \\
\hline 20-Oct & 11.7 & 10.7 \\
\hline 21-Oct & 10.5 & 9.5 \\
\hline 22-Oct & 8.1 & 10.0 \\
\hline 23-Oct & 6.6 & 8.8 \\
\hline 24-Oct & 6.5 & 7.5 \\
\hline 25-Oct & 7.1 & 7.7 \\
\hline 26-Oct & 7.6 & 7.2 \\
\hline 27-Oct & 9.3 & 7.9 \\
\hline 28-Oct & 8.7 & 9.2 \\
\hline 29-Oct & 9.4 & 8.2 \\
\hline 30-Oct & 7.9 & 9.2 \\
\hline 31-Oct & 7.8 & 10.0 \\
\hline $1-\mathrm{Nov}$ & 7.4 & 9.5 \\
\hline 2-Nov & 5.8 & 9.4 \\
\hline 3-Nov & 5.3 & 8.0 \\
\hline 4-Nov & 5.2 & 7.3 \\
\hline 5-Nov & 6.1 & 7.5 \\
\hline 6-Nov & 5.5 & 7.2 \\
\hline 7-Nov & 4.4 & 5.6 \\
\hline 8-Nov & 4.6 & 3.9 \\
\hline 9-Nov & 5.0 & 4.3 \\
\hline 10-Nov & 3.6 & 4.4 \\
\hline $11-\mathrm{Nov}$ & 2.7 & 4.1 \\
\hline 12-Nov & 2.0 & 5.6 \\
\hline $13-\mathrm{Nov}$ & 1.5 & 7.2 \\
\hline 14-Nov & 1.6 & 9.2 \\
\hline $15-\mathrm{Nov}$ & 2.5 & 9.2 \\
\hline $16-\mathrm{Nov}$ & 0.9 & 9.2 \\
\hline 17-Nov & 0.8 & 9.5 \\
\hline 18-Nov & 0.5 & 8.3 \\
\hline 19-Nov & 0.1 & 6.4 \\
\hline 20-Nov & -0.2 & 8.3 \\
\hline 21-Nov & & 8.3 \\
\hline $22-\mathrm{Nov}$ & & 7.7 \\
\hline 23-Nov & & 6.7 \\
\hline 24-Nov & & 3.8 \\
\hline
\end{tabular}

Appendix B. Table B2. Mean daily water temperature for the Imnaha and Snake rivers from February 18, 2001 to February 28, 2001.

\begin{tabular}{ccc} 
Date & Imnaha R. & Snake R. \\
\hline $18-\mathrm{Feb}$ & 4.2 & \\
$19-\mathrm{Feb}$ & 4.4 & \\
$20-\mathrm{Feb}$ & 5.0 & \\
$21-\mathrm{Feb}$ & 5.3 & \\
$22-\mathrm{Feb}$ & 5.7 & 4.5 \\
$23-\mathrm{Feb}$ & 5.7 & 4.5 \\
$24-\mathrm{Feb}$ & 5.6 & 4.4 \\
$25-\mathrm{Feb}$ & 4.3 & 4.3 \\
$26-\mathrm{Feb}$ & 3.9 & 4.1 \\
$27-\mathrm{Feb}$ & 3.0 & 3.9 \\
$28-\mathrm{Feb}$ & 2.3 & 3.7 \\
\hline
\end{tabular}

$$
\text { B - } 2
$$


Appendix B. Table B3. Mean daily temperature for the Imnaha and Snake rivers from March 1, 2001 to June 21, 2001.

\begin{tabular}{|c|c|c|c|c|c|c|c|c|c|c|c|}
\hline Date & Imnaha R. & Snake R. & Date & Imnaha R. & Snake R. & Date & Imnaha R. & Snake R. & Date & Imnaha R. & Snake R. \\
\hline 1-Mar & 2.5 & 3.6 & 1-Apr & 8.0 & 7.9 & 1-May & 7.6 & 9.9 & 1-Jun & 16.4 & 16.6 \\
\hline 2-Mar & 4.5 & 4.1 & 2-Apr & 7.2 & 7.9 & 2-May & 7.9 & 9.6 & 2-Jun & 14.3 & 16.3 \\
\hline 3-Mar & 3.5 & 4.3 & 3-Apr & 6.6 & 8.0 & 3-May & 8.4 & 10.0 & 3-Jun & 11.5 & 15.3 \\
\hline 4-Mar & 3.9 & 4.2 & 4-Apr & 7.5 & 8.0 & 4-May & 10.5 & 11.1 & 4-Jun & 10.8 & 14.7 \\
\hline 5-Mar & 6.4 & 4.5 & 5-Apr & 7.4 & 8.4 & 5-May & 11.3 & 12.0 & 5-Jun & 11.3 & 14.1 \\
\hline 6-Mar & 7.2 & 5.2 & 6-Apr & 7.8 & 8.6 & 6-May & 9.5 & 11.7 & 6-Jun & 13.0 & 14.2 \\
\hline 7-Mar & 7.5 & 5.5 & 7-Apr & 6.4 & 8.3 & 7-May & 10.5 & 11.9 & 7-Jun & 13.9 & 14.5 \\
\hline 8-Mar & 6.7 & 5.4 & 8-Apr & 6.4 & 8.1 & 8-May & 11.6 & 12.6 & 8-Jun & 16.0 & 15.5 \\
\hline 9-Mar & 6.9 & 5.5 & 9-Apr & 6.5 & 8.0 & 9-May & 11.8 & 13.1 & 9-Jun & 17.5 & 16.4 \\
\hline 10-Mar & 6.7 & 5.6 & 10-Apr & 7.0 & 8.1 & 10-May & 11.6 & 13.2 & 10-Jun & 15.4 & 16.5 \\
\hline 11-Mar & 6.6 & 5.8 & 11-Apr & 7.3 & 8.3 & 11-May & 11.6 & 13.2 & 11-Jun & 13.9 & 16.0 \\
\hline 12-Mar & 6.6 & 5.8 & 12-Apr & 7.3 & 8.4 & 12-May & 12.6 & 13.6 & 12-Jun & 12.9 & 15.6 \\
\hline 13-Mar & 7.3 & 6.0 & 13-Apr & 7.3 & 8.5 & 13-May & 12.3 & 13.9 & 13-Jun & 11.7 & 15.3 \\
\hline 14-Mar & 6.8 & 6.2 & 14-Apr & 7.2 & 8.6 & 14-May & 10.2 & 13.1 & 14-Jun & 13.0 & 15.2 \\
\hline 15-Mar & 5.4 & 5.7 & 15-Apr & 8.6 & 9.2 & 15-May & 9.7 & 11.8 & 15-Jun & 15.3 & 15.6 \\
\hline 16-Mar & 6.0 & 5.6 & 16-Apr & 10.0 & 10.0 & 16-May & 10.1 & 11.6 & 16-Jun & 16.3 & 16.4 \\
\hline 17-Mar & 6.6 & 5.9 & 17-Apr & 10.4 & 10.6 & 17-May & 9.6 & 11.5 & 17-Jun & 16.2 & 16.4 \\
\hline 18-Mar & 7.9 & 6.2 & 18-Apr & 10.0 & 10.4 & 18-May & 11.5 & 12.0 & 18-Jun & 15.6 & 16.7 \\
\hline 19-Mar & 9.3 & 7.0 & 19-Apr & 9.2 & 10.3 & 19-May & 11.7 & 12.7 & 19-Jun & 16.7 & 17.3 \\
\hline 20-Mar & 8.4 & 7.1 & 20-Apr & 8.2 & 10.1 & 20-May & 12.2 & 13.1 & 20-Jun & 18.0 & 18.2 \\
\hline 21-Mar & 7.5 & 6.7 & 21-Apr & 8.5 & 10.1 & 21-May & 11.8 & 13.4 & 21-Jun & 19.6 & 18.9 \\
\hline 22-Mar & 7.5 & 6.7 & 22-Apr & 8.6 & 10.3 & 22-May & 13.7 & 14.1 & 22-Jun & 21.0 & \\
\hline 23-Mar & 8.6 & 7.2 & 23-Apr & 9.8 & 10.7 & 23-May & 15.4 & 15.1 & 23-Jun & 20.5 & \\
\hline 24-Mar & 9.5 & 7.9 & 24-Apr & 11.2 & 11.5 & 24-May & 16.6 & 16.1 & & & \\
\hline 25-Mar & 9.3 & 8.4 & 25-Apr & 12.5 & 12.7 & 25-May & 16.2 & 16.5 & & & \\
\hline 26-Mar & 7.9 & 8.4 & 26-Apr & 12.4 & 13.2 & 26-May & 15.8 & 16.3 & & & \\
\hline 27-Mar & 6.3 & 7.3 & 27-Apr & 12.2 & 13.4 & 27-May & 15.4 & 16.0 & & & \\
\hline 28-Mar & 7.6 & 7.3 & 28-Apr & 9.9 & 12.7 & 28-May & 15.6 & 15.9 & & & \\
\hline 29-Mar & 8.5 & 7.7 & 29-Apr & 7.9 & 10.5 & 29-May & 13.6 & 15.5 & & & \\
\hline 30-Mar & 8.6 & 8.1 & 30-Apr & 8.7 & 10.2 & 30-May & 12.9 & 15.0 & & & \\
\hline 31-Mar & 7.0 & 8.0 & & & & 31-May & 15.3 & 15.6 & & & \\
\hline
\end{tabular}

B - 3 
Appendix B. Table B4. Mean daily temperature for the Imnaha and Snake rivers from March 3, 2002 to June 30, 2002.

\begin{tabular}{|c|c|c|c|c|c|c|c|c|c|c|c|}
\hline Date & Imnaha R. & Snake R. & Date & Imnaha R. & Snake R. & Date & Imnaha R. & Snake R. & Date & Imnaha R. & Snake R. \\
\hline 1-Mar & & & $1-\mathrm{Apr}$ & 8.5 & 7.5 & 1-May & 9.6 & 11.0 & 1-Jun & 10.3 & 12.4 \\
\hline 2-Mar & & & 2-Apr & 7.6 & 7.2 & 2-May & 9.4 & 11.3 & 2-Jun & 9.8 & 12.0 \\
\hline 3-Mar & 1.4 & 3.1 & 3-Apr & 7.6 & 7.5 & 3-May & 8.8 & 11.1 & 3-Jun & 10.9 & 12.7 \\
\hline 4-Mar & 2.7 & 3.3 & 4-Apr & 8.3 & 8.0 & 4-May & 7.9 & 10.4 & 4-Jun & 12.0 & 13.2 \\
\hline 5-Mar & 4.0 & 3.6 & 5-Apr & 7.8 & 8.1 & 5-May & 7.8 & 10.0 & 5-Jun & 11.8 & 13.5 \\
\hline 6-Mar & 5.5 & 4.0 & 6-Apr & 8.7 & 8.2 & 6-May & 7.3 & 9.7 & 6-Jun & 11.7 & 13.5 \\
\hline 7-Mar & 4.5 & 4.1 & 7-Apr & 7.7 & 8.2 & 7-May & 6.7 & 9.4 & 7-Jun & 10.0 & 13.1 \\
\hline 8-Mar & 2.3 & 3.8 & 8-Apr & 7.7 & 8.1 & 8-May & 6.6 & 9.3 & 8-Jun & 7.8 & 12.2 \\
\hline 9-Mar & 3.0 & 3.7 & 9-Apr & 8.2 & 8.3 & 9-May & 6.7 & 9.5 & 9-Jun & 7.8 & 11.5 \\
\hline 10-Mar & 4.8 & 4.2 & 10-Apr & 8.1 & 8.1 & 10-May & 7.5 & 9.8 & 10-Jun & 9.0 & 11.6 \\
\hline 11-Mar & 6.7 & 4.7 & 11-Apr & 8.5 & 8.3 & 11-May & 8.8 & 10.1 & 11-Jun & 10.3 & 12.3 \\
\hline 12-Mar & 7.3 & 5.4 & 12-Apr & 9.3 & 8.6 & 12-May & 10.4 & 11.2 & 12-Jun & 11.8 & 13.5 \\
\hline 13-Mar & 5.8 & 5.2 & 13-Apr & 9.4 & 8.9 & 13-May & 11.0 & 12.1 & 13-Jun & 13.6 & 14.8 \\
\hline 14-Mar & 5.7 & 5.2 & 14-Apr & 8.6 & 8.8 & 14-May & 10.4 & 12.2 & 14-Jun & 14.3 & 15.7 \\
\hline 15-Mar & 4.4 & 4.7 & 15-Apr & 5.6 & 7.3 & 15-May & 9.4 & 12.1 & 15-Jun & 14.7 & 16.0 \\
\hline 16-Mar & 4.0 & 4.8 & 16-Apr & 6.4 & 7.3 & 16-May & 9.7 & 12.0 & & & \\
\hline 17-Mar & 2.8 & 4.5 & 17-Apr & 6.8 & 7.4 & 17-May & 9.6 & 12.1 & & & \\
\hline 18-Mar & 3.0 & 4 & 18-Apr & 6.5 & 7.7 & 18-May & 10.6 & 12.1 & & & \\
\hline 19-Mar & 4.3 & 4.1 & 19-Apr & 7.0 & 7.9 & 19-May & 11.2 & 12.7 & & & \\
\hline 20-Mar & 5.6 & 4.6 & 20-Apr & 8.1 & 8.5 & 20-May & 9.3 & 12.2 & & & \\
\hline 21-Mar & 7.0 & 5 & 21-Apr & 8.1 & 9.1 & 21-May & 6.6 & 10.2 & & & \\
\hline 22-Mar & 7.3 & 5.8 & 22-Apr & 9.5 & 9.7 & 22-May & 7.5 & 9.8 & & & \\
\hline 23-Mar & 7.1 & 6.2 & 23-Apr & 8.4 & 9.9 & 23-May & 8.2 & 10.1 & & & \\
\hline 24-Mar & 5.1 & 5.9 & 24-Apr & 6.5 & 9.3 & 24-May & 9.2 & 10.9 & & & \\
\hline 25-Mar & 5.9 & 5.9 & 25-Apr & 8.3 & 9.7 & 25-May & 10.7 & 11.9 & & & \\
\hline 26-Mar & 7.0 & 6.2 & 26-Apr & 8.8 & 10.1 & 26-May & 11.1 & 12.3 & & & \\
\hline 27-Mar & 7.8 & 6.7 & 27-Apr & 7.4 & 9.9 & 27-May & 11.1 & 12.7 & & & \\
\hline 28-Mar & 7.3 & 6.7 & 28-Apr & 8.3 & 9.9 & 28-May & 11.9 & 13.3 & & & \\
\hline 29-Mar & 7.1 & 6.6 & 29-Apr & 9.1 & 10.6 & 29-May & 12.1 & 13.3 & & & \\
\hline 30-Mar & 8.3 & 7.1 & 30-Apr & 9.5 & 11.0 & 30-May & 10.9 & 13.0 & & & \\
\hline 31-Mar & 8.7 & 7.3 & & & & 31-May & 10.6 & 12.5 & & & \\
\hline
\end{tabular}


APPENDIX C

THE CATCH OF CHINOOK SALMON AND STEELHEAD FOR MIGRATION YEARS 2001 AND 2002

C -1 
Appendix C. Table C1. The catch of natural and chinook salmon and steelhead at the upper and lower Imnaha River traps from October 17 to November 15, 2000.

\begin{tabular}{|c|c|c|c|c|c|c|}
\hline \multirow[b]{2}{*}{$\begin{array}{c}\text { Day } \\
\text { Sampling } \\
\text { Ended }\end{array}$} & \multirow[b]{2}{*}{$\begin{array}{l}\text { Hours Fished } \\
\text { at the } \\
\text { Upper Trap }\end{array}$} & \multirow[b]{2}{*}{$\begin{array}{c}\text { Hours Fished } \\
\text { at the } \\
\text { Lower Trap }\end{array}$} & \multicolumn{2}{|c|}{ Upper Trap } & \multicolumn{2}{|c|}{ Lower Trap } \\
\hline & & & $\begin{array}{c}\text { Natural } \\
\text { Chinook } \\
\text { Salmon } \\
\end{array}$ & $\begin{array}{c}\text { Natural } \\
\text { Steelhead }\end{array}$ & $\begin{array}{c}\text { Natural } \\
\text { Chinook } \\
\text { Salmon } \\
\end{array}$ & $\begin{array}{c}\text { Natural } \\
\text { Steelhead }\end{array}$ \\
\hline Oct 17 & 16.0 & 17.5 & 90 & 3 & 19 & 5 \\
\hline Oct 18 & 25.5 & 23.0 & 16 & & 23 & 5 \\
\hline Oct 19 & 28.0 & 23.0 & 39 & & 29 & 13 \\
\hline Oct 20 & 24.0 & 23.0 & 58 & 1 & 46 & 20 \\
\hline Oct 21 & & & & & & \\
\hline Oct 22 & & & & & & \\
\hline Oct 23 & 15.0 & 20.0 & 219 & & 282 & 23 \\
\hline Oct 24 & 23.0 & 22.0 & 167 & 2 & 246 & 22 \\
\hline Oct 25 & 23.0 & 21.0 & 166 & & 215 & 27 \\
\hline Oct 26 & 25.5 & 24.0 & 128 & & 153 & 16 \\
\hline Oct 27 & 24.0 & 18.0 & 501 & 19 & & \\
\hline Oct 28 & & & & & & \\
\hline Oct 29 & & & & & & \\
\hline Oct 30 & 18.0 & 19.0 & 176 & 21 & 1,398 & 117 \\
\hline Oct 31 & 20.0 & & 65 & & & \\
\hline Nov 1 & 24.0 & & 116 & 5 & & \\
\hline Nov 2 & 23.0 & & 72 & 2 & & \\
\hline Nov 3 & 24.0 & & 139 & 5 & & \\
\hline Nov 4 & & & & & & \\
\hline Nov 5 & & & & & & \\
\hline Nov 6 & 13.5 & & 78 & 1 & & \\
\hline Nov 7 & 24.0 & 17.5 & 157 & 2 & 67 & 22 \\
\hline Nov 8 & 22.0 & 24.0 & 28 & 1 & 79 & 21 \\
\hline Nov 9 & 27.0 & 25.0 & 103 & 1 & 81 & 19 \\
\hline Nov 10 & & & & & & \\
\hline Nov 11 & & & & & & \\
\hline Nov 12 & & & & & & \\
\hline Nov 13 & & 14.5 & & & 58 & 7 \\
\hline Nov 14 & & 23.0 & & & 112 & 16 \\
\hline Nov 15 & & 25.5 & & & 173 & 27 \\
\hline Total & 399.5 & 340 & 2,318 & 63 & 2,981 & 360 \\
\hline
\end{tabular}


Appendix C. Table C2. The catch of natural and hatchery chinook salmon and steelhead at the lower Imnaha River traps, A and B, from February 22 to June 21, 2001 (daily samples may exceed 24 hours if sampling continued into the following day).

\begin{tabular}{|c|c|c|c|c|c|c|c|c|c|}
\hline \multirow[b]{2}{*}{$\begin{array}{l}\text { Day } \\
\text { Sampling } \\
\text { Ended }\end{array}$} & \multirow[b]{2}{*}{$\begin{array}{l}\text { Hours } \\
\text { Fished }\end{array}$} & \multicolumn{4}{|c|}{ Trap A } & \multicolumn{4}{|c|}{ Trap B } \\
\hline & & $\begin{array}{l}\text { Natural } \\
\text { Chinook } \\
\text { Salmon } \\
\end{array}$ & $\begin{array}{l}\text { Hatchery } \\
\text { Chinook } \\
\text { Salmon }\end{array}$ & $\begin{array}{l}\text { Natural } \\
\text { Steelhead }\end{array}$ & $\begin{array}{l}\text { Hatchery } \\
\text { Steelhead }\end{array}$ & $\begin{array}{l}\text { Natural } \\
\text { Chinook } \\
\text { Salmon } \\
\end{array}$ & $\begin{array}{l}\text { Hatchery } \\
\text { Chinook } \\
\text { Salmon }\end{array}$ & $\begin{array}{l}\text { Natural } \\
\text { Steelhead }\end{array}$ & $\begin{array}{l}\text { Hatchery } \\
\text { Steelhead }\end{array}$ \\
\hline Feb 22 & 14.0 & 1 & & & & & & & \\
\hline Feb 23 & 22.5 & 4 & & & & & & & \\
\hline Feb 24 & 31.0 & 1 & & & & & & & \\
\hline Feb 25 & 24.0 & 2 & & & & & & & \\
\hline Feb 26 & 24.0 & 1 & & & & & & & \\
\hline Feb 27 & 24.0 & 3 & & 1 & & & & & \\
\hline Feb 28 & 24.0 & 3 & & & & & & & \\
\hline Mar 1 & 25.0 & 4 & & & & & & & \\
\hline Mar 2 & 25.0 & 2 & & 1 & & & & & \\
\hline Mar 3 & 22.5 & 2 & & & & & & & \\
\hline Mar 4 & & & & & & & & & \\
\hline Mar 5 & & & & & & & & & \\
\hline Mar 6 & & & & & & & & & \\
\hline Mar 7 & 23.0 & 5 & & & & & & & \\
\hline Mar 8 & 22.0 & 1 & & & & & & & \\
\hline Mar 9 & 29.0 & 3 & & 1 & & & & & \\
\hline Mar 10 & 20.0 & 2 & & & & & & & \\
\hline Mar 11 & 24.0 & 2 & & & & & & & \\
\hline Mar 12 & 23.5 & 9 & & 1 & & & & & \\
\hline Mar 13 & 23.5 & 3 & & & & & & & \\
\hline Mar 14 & 25.0 & 15 & & & & & & & \\
\hline Mar 15 & 26.0 & 30 & & & & & & & \\
\hline Mar 16 & 25.5 & 126 & & 1 & & 127 & & 2 & \\
\hline Mar 17 & 25.0 & 52 & & & & 53 & & & \\
\hline Mar 18 & 26.0 & 53 & & 1 & & 53 & & & \\
\hline Mar 19 & 23.5 & 48 & & 1 & & 49 & & & \\
\hline Mar 20 & 28.0 & 232 & & 3 & & 234 & & 6 & \\
\hline Mar 21 & 25.0 & 491 & & 11 & & 494 & & 19 & \\
\hline Mar 22 & 23.0 & 518 & & 2 & & 272 & & 16 & \\
\hline Mar 23 & 24.0 & 461 & 5 & 5 & & 288 & 6 & 8 & \\
\hline Mar 24 & 18.5 & 233 & 66 & 4 & & 235 & 40 & 6 & \\
\hline Mar 25 & 26.5 & 193 & 413 & 7 & 1 & & & & \\
\hline Mar 26 & & & & & & & & & \\
\hline Mar 27 & 17.0 & 571 & 364 & 14 & 2 & & & & \\
\hline Mar 28 & 21.0 & 684 & 316 & 26 & & & & & \\
\hline Mar 29 & 17.0 & 188 & 82 & 12 & 2 & & & & \\
\hline Mar 30 & 23.5 & 90 & 100 & 14 & & & & & \\
\hline Mar 31 & 25.0 & 64 & 333 & 3 & & & & & \\
\hline Apr 1 & 28.0 & 277 & 1,081 & 8 & & & & & \\
\hline
\end{tabular}

C -3 
Appendix C. Table C2. Continued.

\begin{tabular}{|c|c|c|c|c|c|c|c|c|c|}
\hline \multirow{2}{*}{$\begin{array}{c}\text { Day } \\
\text { Sampling } \\
\text { Ended }\end{array}$} & \multirow[b]{2}{*}{$\begin{array}{l}\text { Hours } \\
\text { Fished }\end{array}$} & \multicolumn{4}{|c|}{ Trap A } & \multicolumn{4}{|c|}{ Trap B } \\
\hline & & $\begin{array}{l}\text { Natural } \\
\text { Chinook } \\
\text { Salmon }\end{array}$ & $\begin{array}{l}\text { Hatchery } \\
\text { Chinook } \\
\text { Salmon }\end{array}$ & $\begin{array}{c}\text { Natural } \\
\text { Steelhead }\end{array}$ & $\begin{array}{l}\text { Hatchery } \\
\text { Steelhead }\end{array}$ & $\begin{array}{l}\text { Natural } \\
\text { Chinook } \\
\text { Salmon }\end{array}$ & $\begin{array}{l}\text { Hatchery } \\
\text { Chinook } \\
\text { Salmon }\end{array}$ & $\begin{array}{l}\text { Natural } \\
\text { Steelhead }\end{array}$ & $\begin{array}{l}\text { Hatchery } \\
\text { Steelhead }\end{array}$ \\
\hline Apr 2 & 19.5 & 98 & 258 & 4 & & & & & \\
\hline Apr 3 & 26.0 & 208 & 1,256 & 7 & 1 & & & & \\
\hline Apr 4 & 27.5 & 115 & 1,182 & 2 & & & & & \\
\hline Apr 5 & 21.5 & 140 & 817 & 4 & & & & & \\
\hline Apr 6 & 25.0 & 17 & 92 & 1 & & & & & \\
\hline Apr 7 & 24.0 & 9 & 58 & 1 & & & & & \\
\hline Apr 8 & 26.5 & 68 & 202 & 1 & & & & & \\
\hline Apr 9 & 26.5 & 90 & 141 & & & & & & \\
\hline Apr 10 & 22.0 & 68 & 97 & & & & & & \\
\hline Apr 11 & 21.0 & 42 & 101 & 1 & & & & & \\
\hline Apr 12 & 22.5 & 130 & 370 & 11 & & & & & \\
\hline Apr 13 & 21.0 & 106 & 113 & 16 & 4 & & & & \\
\hline Apr 14 & 27.0 & 96 & 61 & 18 & 25 & & & & \\
\hline Apr 15 & 27.0 & 107 & 58 & 31 & 52 & & & & \\
\hline Apr 16 & 22.0 & 67 & 32 & 11 & 11 & & & & \\
\hline Apr 17 & 23.0 & 117 & 30 & 14 & 6 & & & & \\
\hline Apr 18 & 22.0 & 235 & 442 & 89 & 13 & & & & \\
\hline Apr 19 & 18.5 & 288 & 2,866 & 283 & 312 & & & & \\
\hline Apr 20 & 22.0 & 180 & 1,304 & 135 & 710 & & & & \\
\hline Apr 21 & 25.0 & 324 & 1,619 & 82 & 947 & & & & \\
\hline Apr 22 & 22.5 & 168 & 738 & 53 & 714 & & & & \\
\hline Apr 23 & 21.0 & 124 & 372 & 36 & 369 & & & & \\
\hline Apr 24 & 23.5 & 65 & 117 & 48 & 150 & & & & \\
\hline Apr 25 & 24.5 & 65 & 43 & 69 & 56 & & & & \\
\hline Apr 26 & 14.0 & 195 & 125 & 261 & 180 & & & & \\
\hline Apr 27 & 24.0 & 236 & 287 & 744 & 872 & & & & \\
\hline Apr 28 & 1.0 & 24 & & 42 & 150 & & & & \\
\hline Apr 29 & 5.5 & 46 & 46 & 309 & 1,253 & & & & \\
\hline Apr 30 & 2.0 & 12 & 20 & 30 & 93 & & & & \\
\hline May 1 & 14.5 & 75 & 66 & 229 & 630 & & & & \\
\hline May 2 & 12.0 & 47 & 67 & 171 & 240 & & & & \\
\hline May 3 & 26.0 & 79 & 62 & 149 & 420 & & & & \\
\hline May 4 & 24.0 & 53 & 31 & 116 & 243 & & & & \\
\hline May 5 & 26.5 & 15 & 5 & 35 & 73 & & & & \\
\hline May 6 & 25.5 & 43 & 25 & 171 & 248 & & & & \\
\hline May 7 & 24.5 & 36 & 17 & 96 & 152 & & & & \\
\hline May 8 & 24.0 & 15 & 11 & 119 & 239 & & & & \\
\hline May 9 & 22.0 & 34 & 21 & 165 & 439 & & & & \\
\hline May 10 & 24.5 & 79 & 66 & 411 & 1,775 & & & & \\
\hline May 11 & 24.0 & 52 & 33 & 260 & 1,276 & & & & \\
\hline
\end{tabular}

C -4 
Appendix C. Table C2. Continued.

\begin{tabular}{|c|c|c|c|c|c|c|c|c|c|}
\hline \multirow[b]{2}{*}{$\begin{array}{c}\text { Day } \\
\text { Sampling } \\
\text { Ended }\end{array}$} & \multirow[b]{2}{*}{$\begin{array}{l}\text { Hours } \\
\text { Fished }\end{array}$} & \multicolumn{4}{|c|}{ Trap A } & \multicolumn{4}{|c|}{ Trap B } \\
\hline & & $\begin{array}{l}\text { Natural } \\
\text { Chinook } \\
\text { Salmon } \\
\end{array}$ & $\begin{array}{l}\text { Hatchery } \\
\text { Chinook } \\
\text { Salmon }\end{array}$ & $\begin{array}{c}\text { Natural } \\
\text { Steelhead }\end{array}$ & $\begin{array}{l}\text { Hatchery } \\
\text { Steelhead }\end{array}$ & $\begin{array}{l}\text { Natural } \\
\text { Chinook } \\
\text { Salmon } \\
\end{array}$ & $\begin{array}{l}\text { Hatchery } \\
\text { Chinook } \\
\text { Salmon }\end{array}$ & $\begin{array}{c}\text { Natural } \\
\text { Steelhead }\end{array}$ & $\begin{array}{l}\text { Hatchery } \\
\text { Steelhead }\end{array}$ \\
\hline May 12 & 23.0 & 40 & 19 & 229 & 1,392 & & & & \\
\hline May 13 & & & & & & & & & \\
\hline May 14 & 10.5 & 12 & 8 & 296 & 3,477 & & & & \\
\hline May 15 & 24.0 & 81 & & 619 & 6,136 & & & & \\
\hline May 16 & 8.0 & 8 & 2 & 218 & 1,145 & & & & \\
\hline May 17 & 9.0 & 6 & 1 & 110 & 592 & & & & \\
\hline May 18 & 28.0 & 19 & 2 & 76 & 368 & & & & \\
\hline May 19 & & & & & & & & & \\
\hline May 20 & & & & & & & & & \\
\hline May 21 & 14.0 & 10 & 1 & 55 & 288 & & & & \\
\hline May 22 & 23.0 & 8 & & 45 & 189 & & & & \\
\hline May 23 & 22.5 & 33 & 2 & 48 & 265 & & & & \\
\hline May 24 & 25.5 & 15 & & 21 & 132 & 19 & 2 & 30 & 52 \\
\hline May 25 & 24.5 & 30 & 2 & 27 & 337 & 29 & 1 & 44 & 100 \\
\hline May 26 & & & & & & & & & \\
\hline May 27 & & & & & & & & & \\
\hline May 28 & & & & & & & & & \\
\hline May 29 & 14.0 & 7 & & 16 & 549 & 12 & & 71 & 206 \\
\hline May 30 & 24.5 & 9 & & 23 & 585 & 11 & & 39 & 114 \\
\hline May 31 & 24.0 & 5 & & 31 & 219 & & & & \\
\hline Jun 1 & 24.0 & 9 & & 14 & 124 & & & & \\
\hline Jun 2 & & & & & & & & & \\
\hline Jun 3 & & & & & & & & & \\
\hline Jun 4 & 14.0 & 9 & & 15 & 104 & & & & \\
\hline Jun 5 & 23.0 & 10 & & 12 & 72 & & & & \\
\hline Jun 6 & 21.0 & 9 & & 10 & 46 & & & & \\
\hline Jun 7 & 23.5 & 11 & & & 38 & & & & \\
\hline Jun 8 & 24.0 & 13 & & & 40 & & & & \\
\hline Jun 9 & & & & & & & & & \\
\hline Jun 10 & & & & & & & & & \\
\hline Jun 11 & 10.0 & 20 & & & 19 & & & & \\
\hline Jun 12 & 24.0 & 17 & & 3 & 74 & & & & \\
\hline Jun 13 & 24.0 & 23 & & 6 & 55 & & & & \\
\hline Jun 14 & 26.0 & 18 & & 5 & 30 & & & & \\
\hline Jun 15 & 6.0 & & & & & & & & \\
\hline Jun 16 & & & & & & & & & \\
\hline Jun 17 & & & & & & & & & \\
\hline Jun 18 & & & & & & & & & \\
\hline Jun 19 & & & & & & & & & \\
\hline Jun 20 & 11.0 & 12 & & 1 & 23 & & & & \\
\hline
\end{tabular}

C -5 
Appendix C. Table C2. Continued.

\begin{tabular}{lc|cccc|cccc|}
\hline & & \multicolumn{4}{|c|}{ Trap A } & \multicolumn{4}{c|}{ Trap B } \\
$\begin{array}{l}\text { Day } \\
\begin{array}{l}\text { Sampling } \\
\text { Ended }\end{array}\end{array}$ & $\begin{array}{c}\text { Hours } \\
\text { Fished }\end{array}$ & $\begin{array}{c}\text { Natural } \\
\text { Chinook } \\
\text { Salmon }\end{array}$ & $\begin{array}{c}\text { Hatchery } \\
\text { Chinook } \\
\text { Salmon }\end{array}$ & $\begin{array}{c}\text { Natural } \\
\text { Steelhead }\end{array}$ & $\begin{array}{c}\text { Hatchery } \\
\text { Steelhead }\end{array}$ & $\begin{array}{c}\text { Natural } \\
\text { Chinook } \\
\text { Salmon }\end{array}$ & $\begin{array}{c}\text { Hatchery } \\
\text { Chinook } \\
\text { Salmon }\end{array}$ & $\begin{array}{c}\text { Natural } \\
\text { Steelhead }\end{array}$ & $\begin{array}{c}\text { Hatchery } \\
\text { Steelhead }\end{array}$ \\
\hline Jun 21 & 23.0 & 11 & & & 22 & & & & \\
\hline Totals & $2,211.5$ & 8,787 & 16,048 & 6,221 & 27,979 & 1,876 & 49 & 241 & 472
\end{tabular}

C -6 
Appendix C. Table C3. The catch of natural and chinook salmon and steelhead at the upper and lower Imnaha River traps from October 17 to November 27, 2001.

\begin{tabular}{|c|c|c|c|c|c|c|}
\hline \multirow[b]{2}{*}{$\begin{array}{c}\text { Day } \\
\text { Sampling } \\
\text { Ended }\end{array}$} & \multirow[b]{2}{*}{$\begin{array}{c}\text { Hours Fished } \\
\text { at the } \\
\text { Upper Trap }\end{array}$} & \multirow[b]{2}{*}{$\begin{array}{c}\text { Hours Fished } \\
\text { at the } \\
\text { Lower Trap }\end{array}$} & \multicolumn{2}{|c|}{ Upper Trap } & \multicolumn{2}{|c|}{ Lower Trap } \\
\hline & & & $\begin{array}{l}\text { Natural } \\
\text { Chinook } \\
\text { Salmon }\end{array}$ & $\begin{array}{c}\text { Natural } \\
\text { Steelhead }\end{array}$ & $\begin{array}{l}\text { Natural } \\
\text { Chinook } \\
\text { Salmon }\end{array}$ & $\begin{array}{c}\text { Natural } \\
\text { Steelhead }\end{array}$ \\
\hline Oct 17 & & 20.0 & & & 62 & 21 \\
\hline Oct 18 & 35.5 & 24.0 & 48 & 2 & 25 & 15 \\
\hline Oct 19 & 23.5 & 23.5 & 43 & & 66 & 30 \\
\hline Oct 20 & 25.5 & & 46 & & & \\
\hline Oct 21 & & & & & & \\
\hline Oct 22 & & & & & & \\
\hline Oct 23 & 16.5 & 19.5 & 32 & & 68 & 70 \\
\hline Oct 24 & 26.5 & 25.5 & 274 & 4 & 236 & 120 \\
\hline Oct 25 & 19.0 & 25.5 & 58 & & 367 & 73 \\
\hline Oct 26 & 25.0 & 19.0 & 41 & & 164 & 56 \\
\hline Oct 27 & & & & & & \\
\hline Oct 28 & & & & & & \\
\hline Oct 29 & & 13.0 & & & 43 & 46 \\
\hline Oct 30 & 41.0 & 23.5 & 20 & & 11 & 78 \\
\hline Oct 31 & 24.0 & 22.5 & 75 & 4 & 169 & 159 \\
\hline Nov 1 & 24.0 & 32.0 & 175 & 17 & 334 & 165 \\
\hline Nov 2 & 23.5 & & 68 & 10 & & \\
\hline Nov 3 & & & & & & \\
\hline Nov 4 & & & & & & \\
\hline Nov 5 & 21.0 & 12.5 & 34 & & 83 & 19 \\
\hline Nov 6 & 22.5 & 12.0 & 49 & & 114 & 28 \\
\hline Nov 7 & 22.5 & 13.3 & 49 & & 162 & 44 \\
\hline Nov 8 & 25.5 & 25.0 & 53 & & 245 & 24 \\
\hline Nov 9 & 25.0 & & 108 & & & \\
\hline Nov 10 & & & & & & \\
\hline Nov 11 & & & & & & \\
\hline Nov 12 & & & & & & \\
\hline Nov 13 & 16.5 & & 22 & & & \\
\hline Nov 14 & 24.0 & & 33 & & & \\
\hline Nov 15 & 24.5 & & 17 & & & \\
\hline Nov 16 & 24.0 & & 19 & & & \\
\hline Nov 17 & 15.5 & & & & & \\
\hline Nov 18 & & & & & & \\
\hline Nov 19 & & & 38 & & & \\
\hline Nov 20 & 23.5 & & 51 & & & \\
\hline Nov 21 & 25.0 & & 40 & 7 & & \\
\hline Nov 26 & 13.0 & & 17 & 2 & & \\
\hline Nov 27 & 24.0 & & 5 & & & \\
\hline Total & 590.5 & 310.8 & 1,415 & 46 & 2,149 & 948 \\
\hline
\end{tabular}

C -7 
Appendix C. Table C4. The catch of natural and hatchery chinook salmon and steelhead at the Imnaha River traps, A and B, from March 4 to June 12, 2002 (daily samples may exceed 24 hours if sampling continued into the following day).

\begin{tabular}{|c|c|c|c|c|c|c|c|c|c|}
\hline \multirow{2}{*}{$\begin{array}{c}\text { Day } \\
\text { Sampling } \\
\text { Ended }\end{array}$} & \multirow[b]{2}{*}{$\begin{array}{l}\text { Hours } \\
\text { Fished }\end{array}$} & \multicolumn{4}{|c|}{ Trap A } & \multicolumn{4}{|c|}{ Trap B } \\
\hline & & $\begin{array}{l}\text { Natural } \\
\text { Chinook } \\
\text { Salmon } \\
\end{array}$ & $\begin{array}{l}\text { Hatchery } \\
\text { Chinook } \\
\text { Salmon }\end{array}$ & $\begin{array}{l}\text { Natural } \\
\text { Steelhead }\end{array}$ & $\begin{array}{l}\text { Hatchery } \\
\text { Steelhead }\end{array}$ & $\begin{array}{l}\text { Natural } \\
\text { Chinook } \\
\text { Salmon }\end{array}$ & $\begin{array}{l}\text { Hatchery } \\
\text { Chinook } \\
\text { Salmon }\end{array}$ & $\begin{array}{l}\text { Natural } \\
\text { Steelhead }\end{array}$ & $\begin{array}{l}\text { Hatchery } \\
\text { Steelhead }\end{array}$ \\
\hline Mar 3 & & & & & & & & & \\
\hline Mar 4 & 17.5 & 3 & & 1 & & & & & \\
\hline Mar 5 & 25.5 & 1 & & 4 & & & & & \\
\hline Mar 6 & 25 & 1 & & 2 & & & & & \\
\hline Mar 7 & 26 & & & 1 & & & & & \\
\hline Mar 8 & 24 & 2 & 2 & 1 & & & & & \\
\hline Mar 9 & 24.5 & 4 & 5 & & & & & & \\
\hline Mar 10 & & & & & & & & & \\
\hline Mar 11 & 47 & 5 & 3 & 5 & & & & & \\
\hline Mar 12 & 24.5 & & 3 & 2 & & & & & \\
\hline Mar 13 & 24 & 1 & & 2 & & & & & \\
\hline Mar 14 & 24 & 2 & 1 & 3 & & & & & \\
\hline Mar 15 & 24 & 5 & & 1 & & & & & \\
\hline Mar 16 & 24 & 5 & 2 & 1 & & & & & \\
\hline Mar 17 & 24 & 3 & & 1 & & & & & \\
\hline Mar 18 & 23 & 10 & 1 & 1 & & & & & \\
\hline Mar 19 & 25 & 3 & & & & & & & \\
\hline Mar 20 & 23.25 & & 1 & & & & & & \\
\hline Mar 21 & & & & & & & & & \\
\hline Mar 22 & 23 & 1 & & & & & & & \\
\hline Mar 23 & 26.25 & 2 & 141 & & & & & & \\
\hline Mar 24 & 22.5 & 35 & 402 & 1 & & & & & \\
\hline Mar 25 & 25 & 139 & 262 & 5 & 1 & & & & \\
\hline Mar 26 & 26 & 93 & 148 & 9 & & & & & \\
\hline Mar 27 & 23 & 74 & 1,737 & 8 & & & & & \\
\hline Mar 28 & 23 & 67 & 6,914 & 35 & & & & & \\
\hline Mar 29 & 22.5 & 120 & 3,711 & 16 & & & & & \\
\hline Mar 30 & & & & & & & & & \\
\hline Mar 31 & 18.75 & 23 & 1,742 & 12 & & & & & \\
\hline Apr 1 & 24 & 43 & 2,677 & 15 & & & & & \\
\hline Apr 2 & & & & & & & & & \\
\hline Apr 3 & 18 & 29 & 635 & 10 & & & & & \\
\hline Apr 4 & 15 & 76 & 1,366 & 7 & & & & & \\
\hline Apr 5 & 23 & 114 & 781 & 4 & & & & & \\
\hline Apr 6 & & & & & & & & & \\
\hline Apr 7 & 16.3 & 26 & 187 & 26 & & & & & \\
\hline Apr 8 & 24.5 & 54 & 314 & 12 & & & & & \\
\hline Apr 9 & 25 & 100 & 406 & 7 & & & & & \\
\hline Apr 10 & 20.5 & 39 & 501 & 10 & & & & & \\
\hline Apr 11 & 24 & 8 & 132 & 6 & 2 & & & & \\
\hline
\end{tabular}

C -8 
Appendix C. Table C4. Continued.

\begin{tabular}{|c|c|c|c|c|c|c|c|c|c|}
\hline \multirow[b]{2}{*}{$\begin{array}{c}\text { Day } \\
\text { Sampling } \\
\text { Ended }\end{array}$} & \multirow[b]{2}{*}{$\begin{array}{l}\text { Hours } \\
\text { Fished }\end{array}$} & \multicolumn{4}{|c|}{ Trap A } & \multicolumn{4}{|c|}{ Trap B } \\
\hline & & $\begin{array}{l}\text { Natural } \\
\text { Chinook } \\
\text { Salmon }\end{array}$ & $\begin{array}{c}\text { Hatchery } \\
\text { Chinook } \\
\text { Salmon }\end{array}$ & $\begin{array}{c}\text { Natural } \\
\text { Steelhead }\end{array}$ & $\begin{array}{l}\text { Hatchery } \\
\text { Steelhead }\end{array}$ & $\begin{array}{c}\text { Natural } \\
\text { Chinook } \\
\text { Salmon } \\
\end{array}$ & $\begin{array}{l}\text { Hatchery } \\
\text { Chinook } \\
\text { Salmon }\end{array}$ & $\begin{array}{c}\text { Natural } \\
\text { Steelhead }\end{array}$ & $\begin{array}{l}\text { Hatchery } \\
\text { Steelhead }\end{array}$ \\
\hline Apr 12 & 10 & 25 & 323 & 13 & 92 & & & & \\
\hline Apr 13 & 11 & 5 & 105 & 3 & 45 & & & & \\
\hline Apr 14 & 6 & 1 & 92 & 8 & 36 & & & & \\
\hline \multicolumn{10}{|l|}{ Apr 15} \\
\hline \multicolumn{10}{|l|}{ Apr 16} \\
\hline Apr 17 & 11 & 54 & 404 & 28 & 80 & & & & \\
\hline Apr 18 & 14 & 103 & 400 & 51 & 306 & & & & \\
\hline Apr 19 & 24.5 & 141 & 1,193 & 67 & 933 & & & & \\
\hline Apr 20 & 24 & 85 & 286 & 36 & 1,469 & & & & \\
\hline Apr 21 & 23.5 & 97 & 197 & 43 & 1,275 & & & & \\
\hline Apr 22 & 25 & 58 & 151 & 48 & 589 & & & & \\
\hline Apr 23 & 26.5 & 35 & 106 & 44 & 112 & & & & \\
\hline Apr 24 & 24.5 & 90 & 192 & 55 & 205 & & & & \\
\hline Apr 25 & 23 & 77 & 96 & 30 & 131 & & & & \\
\hline Apr 26 & 24 & 43 & 46 & 29 & 35 & & & & \\
\hline Apr 27 & 22 & 42 & 54 & 54 & 146 & & & & \\
\hline Apr 28 & 30 & 114 & 157 & 81 & 220 & & & & \\
\hline Apr 29 & 20 & 50 & 65 & 55 & 105 & & & & \\
\hline Apr 30 & 24.5 & 50 & 95 & 85 & 224 & 73 & 43 & 51 & 6 \\
\hline May 1 & 24 & 56 & 150 & 182 & 562 & 89 & 2 & 122 & \\
\hline May 2 & 20.5 & 9 & 36 & 49 & 188 & 5 & 1 & 2 & \\
\hline May 3 & 23 & 6 & 15 & 149 & 351 & & & & \\
\hline \multicolumn{10}{|l|}{ May 4} \\
\hline May 5 & 15 & 4 & 11 & 127 & 369 & & & & \\
\hline May 6 & 20.5 & 9 & 9 & 107 & 256 & & & & \\
\hline May 7 & 23 & 15 & 21 & 138 & 255 & & & & \\
\hline May 8 & 25.5 & 17 & 17 & 128 & 262 & & & & \\
\hline May 9 & 24.75 & 1 & 1 & 62 & 2,469 & & & & \\
\hline May 10 & 19.25 & 14 & 5 & 91 & 1,307 & & & & \\
\hline \multicolumn{10}{|l|}{ May 11} \\
\hline May 12 & 12.25 & 16 & 6 & 243 & 931 & & & & \\
\hline May 13 & 24 & 84 & 5 & 442 & 882 & & & & \\
\hline May 14 & 24.75 & 26 & 16 & 766 & 1,388 & & & & \\
\hline May 15 & 13.75 & 11 & 6 & 718 & 1,925 & & & & \\
\hline May 16 & 22 & 13 & 7 & 462 & 1,372 & & & & \\
\hline May 17 & 24.5 & 15 & 7 & 390 & 904 & & & & \\
\hline May 18 & 11.5 & 8 & 2 & 302 & 884 & & & & \\
\hline May 19 & 24 & 17 & 9 & 663 & 2,402 & & & & \\
\hline \multicolumn{10}{|l|}{ May 20} \\
\hline \multicolumn{10}{|l|}{ May 21} \\
\hline May 22 & 10.5 & 6 & 1 & 60 & 237 & & & & \\
\hline
\end{tabular}

C - 9 
Appendix C. Table C4. Continued.

\begin{tabular}{|c|c|c|c|c|c|c|c|c|c|}
\hline \multirow[b]{2}{*}{$\begin{array}{l}\text { Day } \\
\text { Sampling } \\
\text { Ended }\end{array}$} & \multirow[b]{2}{*}{$\begin{array}{l}\text { Hours } \\
\text { Fished }\end{array}$} & \multicolumn{4}{|c|}{ Trap A } & \multicolumn{4}{|c|}{ Trap B } \\
\hline & & $\begin{array}{l}\text { Natural } \\
\text { Chinook } \\
\text { Salmon } \\
\end{array}$ & $\begin{array}{l}\text { Hatchery } \\
\text { Chinook } \\
\text { Salmon }\end{array}$ & $\begin{array}{c}\text { Natural } \\
\text { Steelhead }\end{array}$ & $\begin{array}{l}\text { Hatchery } \\
\text { Steelhead }\end{array}$ & $\begin{array}{c}\text { Natural } \\
\text { Chinook } \\
\text { Salmon } \\
\end{array}$ & $\begin{array}{l}\text { Hatchery } \\
\text { Chinook } \\
\text { Salmon }\end{array}$ & $\begin{array}{c}\text { Natural } \\
\text { Steelhead }\end{array}$ & $\begin{array}{l}\text { Hatchery } \\
\text { Steelhead }\end{array}$ \\
\hline May 23 & 13.75 & 6 & & 51 & 178 & & & & \\
\hline May 24 & 25.5 & 2 & 1 & 65 & 115 & & & & \\
\hline May 25 & & & & & & & & & \\
\hline May 26 & & & & & & & & & \\
\hline May 27 & & & & & & & & & \\
\hline May 28 & 21 & 9 & & 186 & 645 & & & & \\
\hline May 29 & 12.5 & 2 & & 124 & 526 & & & & \\
\hline May 30 & 9.5 & & & 47 & 188 & & & & \\
\hline May 31 & & & & & & & & & \\
\hline Jun 1 & & & & & & & & & \\
\hline Jun 2 & & & & & & & & & \\
\hline Jun 3 & 12 & 2 & & 29 & 56 & & & & \\
\hline Jun 4 & 23.25 & & & 34 & 53 & & & & \\
\hline Jun 5 & 24.5 & 2 & & 39 & 66 & & & & \\
\hline Jun 6 & 24 & 2 & & 52 & 51 & & & & \\
\hline Jun 7 & 23.75 & 3 & & 46 & 68 & & & & \\
\hline Jun 8 & 25.25 & 3 & & 35 & 31 & & & & \\
\hline Jun 9 & 24 & 7 & & 28 & 87 & & & & \\
\hline Jun 10 & 25 & 1 & & 15 & 30 & & & & \\
\hline Jun 11 & 23.25 & 1 & & 10 & 17 & & & & \\
\hline Jun 12 & 23.75 & 1 & & 3 & 19 & & & & \\
\hline Totals & 1822.8 & 2,526 & 26,361 & 6,781 & 25,080 & 167 & 46 & 175 & 6 \\
\hline
\end{tabular}

C -10 
Appendix C. Table C5. PIT tagged recaptured natural chinook salmon in the lower Imnaha River trap during the fall for migration years 2001 and 2002.

\begin{tabular}{|c|c|c|c|c|c|c|}
\hline $\begin{array}{l}\text { Migration } \\
\text { Year }\end{array}$ & Agency & $\begin{array}{l}\text { Recapture } \\
\text { File }\end{array}$ & Tag ID & $\begin{array}{c}\text { Date } \\
\text { Tagged }\end{array}$ & $\begin{array}{c}\text { Date } \\
\text { Recaptured }\end{array}$ & Travel Time \\
\hline 2001 & ODFW & JAH00318.NT1 & 3D9.1BF100B5D0 & $8 / 28 / 00$ & $11 / 13 / 00$ & 76 days $19 \mathrm{hrs} 31 \mathrm{mins}$ \\
\hline 2001 & ODFW & JAH00291.NT1 & 3D9.1BF1005F21 & $8 / 29 / 00$ & $10 / 17 / 00$ & 48 days $13 \mathrm{hrs} 18 \mathrm{mins}$ \\
\hline 2001 & ODFW & JAH00304.NT1 & 3D9.1BF0FF1D8E & $8 / 29 / 00$ & $10 / 30 / 00$ & 61 days $13 \mathrm{hrs} 36 \mathrm{mins}$ \\
\hline 2001 & ODFW & JAH00304.NT1 & 3D9.1BF0FF1E01 & $8 / 29 / 00$ & $10 / 30 / 00$ & 61 days $13 \mathrm{hrs} 17 \mathrm{mins}$ \\
\hline 2001 & ODFW & JAH00304.NT1 & 3D9.1BF0FF7921 & $8 / 29 / 00$ & $10 / 30 / 00$ & 61 days 12 hrs 22 mins \\
\hline 2001 & ODFW & JAH00298.NT1 & 3D9.1BF0FF07EE & $8 / 30 / 00$ & $10 / 24 / 00$ & 54 days $20 \mathrm{hrs} 52 \mathrm{mins}$ \\
\hline 2001 & ODFW & JAH00304.NT1 & 3D9.1BF1005A32 & $8 / 30 / 00$ & $10 / 30 / 00$ & 60 days $20 \mathrm{hrs} 37 \mathrm{mins}$ \\
\hline 2001 & ODFW & JAH00319.NT1 & 3D9.1BF100CBD6 & $8 / 30 / 00$ & $11 / 14 / 00$ & 75 days $20 \mathrm{hrs} 15 \mathrm{mins}$ \\
\hline 2001 & NPT & JAH00297.NT1 & 3D9.1BF0FF743B & $10 / 17 / 00$ & $10 / 23 / 00$ & 5 days $13 \mathrm{hrs} 37 \mathrm{mins}$ \\
\hline 2001 & NPT & JAH00304.NT1 & 3D9.1BF0FF295D & $10 / 17 / 00$ & $10 / 30 / 00$ & 12 days $13 \mathrm{hrs} 21 \mathrm{mins}$ \\
\hline 2001 & NPT & JAH00304.NT1 & 3D9.1BF0FF353E & $10 / 17 / 00$ & $10 / 30 / 00$ & 12 days $13 \mathrm{hrs} 21 \mathrm{mins}$ \\
\hline 2001 & NPT & JAH00293.NT1 & 3D9.1BF0FF64A8 & $10 / 18 / 00$ & $10 / 19 / 00$ & $12 \mathrm{hrs}$ \\
\hline 2001 & NPT & JAH00304.NT1 & 3D9.1BF0FF341E & $10 / 18 / 00$ & $10 / 30 / 00$ & 11 days $12 \mathrm{hrs} 51 \mathrm{mins}$ \\
\hline 2001 & NPT & JAH00294.NT1 & 3D9.1BF0FF5B27 & $10 / 19 / 00$ & $10 / 20 / 00$ & $11 \mathrm{hrs} 40 \mathrm{mins}$ \\
\hline 2001 & NPT & JAH00304.NT1 & 3D9.1BF0FF2FE2 & $10 / 19 / 00$ & $10 / 30 / 00$ & 10 days $13 \mathrm{hrs} 6 \mathrm{mins}$ \\
\hline 2001 & NPT & JAH00297.NT1 & 3D9.1BF0FF35F0 & $10 / 20 / 00$ & $10 / 23 / 00$ & 2 days $21 \mathrm{hrs} 37$ mins \\
\hline 2001 & NPT & JAH00299.NT1 & 3D9.1BF0FF1521 & $10 / 20 / 00$ & $10 / 25 / 00$ & 4 days 19 hrs 57 mins \\
\hline 2001 & NPT & JAH00320.NT1 & 3D9.1BF0FFE4AE & $10 / 20 / 00$ & $11 / 15 / 00$ & 25 days 21 hrs 10 mins \\
\hline 2001 & NPT & JAH00304.NT1 & 3D9.1BF0FF0549 & $10 / 23 / 00$ & $10 / 30 / 00$ & 6 days $13 \mathrm{hrs} 21 \mathrm{mins}$ \\
\hline 2001 & NPT & JAH00304.NT1 & 3D9.1BF0FF2E86 & $10 / 23 / 00$ & $10 / 30 / 00$ & 6 days 13 hrs 21 mins \\
\hline 2001 & NPT & JAH00304.NT1 & 3D9.1BF0FF15AA & $10 / 23 / 00$ & $10 / 30 / 00$ & 6 days $13 \mathrm{hrs} 21 \mathrm{mins}$ \\
\hline 2001 & NPT & JAH00304.NT1 & 3D9.1BF0FF04AA & $10 / 23 / 00$ & $10 / 30 / 00$ & 6 days $13 \mathrm{hrs} 21 \mathrm{mins}$ \\
\hline 2001 & NPT & JAH00304.NT1 & 3D9.1BF0FF0577 & $10 / 23 / 00$ & $10 / 30 / 00$ & 6 days $13 \mathrm{hrs} 21 \mathrm{mins}$ \\
\hline 2001 & NPT & JAH00304.NT1 & 3D9.1BF0FF755A & $10 / 23 / 00$ & $10 / 30 / 00$ & 6 days $13 \mathrm{hrs} 21 \mathrm{mins}$ \\
\hline 2001 & NPT & JAH00304.NT1 & 3D9.1BF0FFA024 & $10 / 23 / 00$ & $10 / 30 / 00$ & 6 days $13 \mathrm{hrs} 21 \mathrm{mins}$ \\
\hline 2001 & NPT & JAH00304.NT1 & 3D9.1BF0FFA254 & $10 / 23 / 00$ & $10 / 30 / 00$ & 6 days $13 \mathrm{hrs} 21 \mathrm{mins}$ \\
\hline 2001 & NPT & JAH00304.NT1 & 3D9.1BF1011121 & $10 / 23 / 00$ & $10 / 30 / 00$ & 6 days $13 \mathrm{hrs} 21 \mathrm{mins}$ \\
\hline 2001 & NPT & JAH00314.NT1 & 3D9.1BF10014AC & $10 / 23 / 00$ & $11 / 9 / 00$ & 16 days $14 \mathrm{hrs} 1 \mathrm{mins}$ \\
\hline 2001 & NPT & JAH00298.NT1 & 3D9.1BF0FF9EB5 & $10 / 23 / 00$ & $10 / 24 / 00$ & $13 \mathrm{hrs} 36 \mathrm{mins}$ \\
\hline 2001 & NPT & JAH00304.NT1 & 3D9.1BF0FF02C9 & $10 / 24 / 00$ & $10 / 30 / 00$ & 5 days $12 \mathrm{hrs} 21 \mathrm{mins}$ \\
\hline 2001 & NPT & JAH00304.NT1 & 3D9.1BF0FF0D6E & $10 / 24 / 00$ & $10 / 30 / 00$ & 5 days $12 \mathrm{hrs} 21 \mathrm{mins}$ \\
\hline 2001 & NPT & JAH00304.NT1 & 3D9.1BF0FF2B6B & $10 / 24 / 00$ & $10 / 30 / 00$ & 5 days $12 \mathrm{hrs} 21 \mathrm{mins}$ \\
\hline 2001 & NPT & JAH00304.NT1 & 3D9.1BF10051A1 & $10 / 24 / 00$ & $10 / 30 / 00$ & 5 days $12 \mathrm{hrs} 21 \mathrm{mins}$ \\
\hline 2001 & NPT & JAH00304.NT1 & 3D9.1BF10059F5 & $10 / 24 / 00$ & $10 / 30 / 00$ & 5 days $12 \mathrm{hrs} 21 \mathrm{mins}$ \\
\hline 2001 & NPT & JAH00314.NT1 & 3D9.1BF0FFA3F0 & $10 / 24 / 00$ & $11 / 9 / 00$ & 15 days $13 \mathrm{hrs} 1 \mathrm{mins}$ \\
\hline 2001 & NPT & JAH00299.NT1 & 3D9.1BF0FF33BA & $10 / 24 / 00$ & $10 / 25 / 00$ & $11 \mathrm{hrs} 57 \mathrm{mins}$ \\
\hline 2001 & NPT & JAH00300.NT1 & 3D9.1BF0FF385D & $10 / 25 / 00$ & $10 / 26 / 00$ & $12 \mathrm{hrs} 16 \mathrm{mins}$ \\
\hline 2001 & NPT & JAH00304.NT1 & 3D9.1BF0FF9FCC & $10 / 25 / 00$ & $10 / 30 / 00$ & 4 days 13 hrs 21 mins \\
\hline 2001 & NPT & JAH00304.NT1 & 3D9.1BF0FF0780 & $10 / 25 / 00$ & $10 / 30 / 00$ & 4 days 13 hrs 21 mins \\
\hline 2001 & NPT & JAH00304.NT1 & 3D9.1BF0FF0E06 & $10 / 25 / 00$ & $10 / 30 / 00$ & 4 days $13 \mathrm{hrs} 21 \mathrm{mins}$ \\
\hline 2001 & NPT & JAH00304.NT1 & 3D9.1BF0FF1F36 & $10 / 25 / 00$ & $10 / 30 / 00$ & 4 days $13 \mathrm{hrs} 21 \mathrm{mins}$ \\
\hline 2001 & NPT & JAH00304.NT1 & 3D9.1BF0FF1F61 & $10 / 25 / 00$ & $10 / 30 / 00$ & 4 days 13 hrs 21 mins \\
\hline 2001 & NPT & JAH00304.NT1 & 3D9.1BF0FF286D & $10 / 25 / 00$ & $10 / 30 / 00$ & 4 days 13 hrs 21 mins \\
\hline
\end{tabular}

C -11 
Appendix C. Table C5. Continued.

\begin{tabular}{|c|c|c|c|c|c|c|}
\hline $\begin{array}{c}\text { Migration } \\
\text { Year } \\
\end{array}$ & Agency & $\begin{array}{l}\text { Recapture } \\
\text { File } \\
\end{array}$ & Tag ID & $\begin{array}{c}\text { Date } \\
\text { Tagged }\end{array}$ & $\begin{array}{c}\text { Date } \\
\text { Recaptured }\end{array}$ & Travel Time \\
\hline 2001 & NPT & JAH00304.NT1 & 3D9.1BF0FF25A2 & $10 / 26 / 00$ & $10 / 30 / 00$ & 3 days $13 \mathrm{hrs} 21 \mathrm{mins}$ \\
\hline 2001 & NPT & JAH00304.NT1 & 3D9.1BF0FF2C19 & $10 / 26 / 00$ & $10 / 30 / 00$ & 3 days $13 \mathrm{hrs} 21 \mathrm{mins}$ \\
\hline 2001 & NPT & JAH00304.NT1 & 3D9.1BF0FF32F8 & $10 / 26 / 00$ & $10 / 30 / 00$ & 3 days $13 \mathrm{hrs} 21 \mathrm{mins}$ \\
\hline 2001 & NPT & JAH00304.NT1 & 3D9.1BF0FF7453 & $10 / 26 / 00$ & $10 / 30 / 00$ & 3 days $13 \mathrm{hrs} 21 \mathrm{mins}$ \\
\hline 2001 & NPT & JAH00304.NT1 & 3D9.1BF0FF23B9 & $10 / 26 / 00$ & $10 / 30 / 00$ & 3 days $13 \mathrm{hrs} 21 \mathrm{mins}$ \\
\hline 2001 & NPT & JAH00313.NT1 & 3D9.1BF101123C & $10 / 26 / 00$ & $11 / 8 / 00$ & 12 days $13 \mathrm{hrs} 47 \mathrm{mins}$ \\
\hline 2001 & NPT & JAH00314.NT1 & 3D9.1BF100C0ED & $10 / 26 / 00$ & $11 / 9 / 00$ & 13 days $14 \mathrm{hrs} 1 \mathrm{mins}$ \\
\hline 2001 & NPT & JAH00304.NT1 & 3D9.1BF100C521 & $10 / 27 / 00$ & $10 / 30 / 00$ & 2 days $12 \mathrm{hrs} 21 \mathrm{mins}$ \\
\hline 2001 & NPT & JAH00304.NT1 & 3D9.1BF0FF256B & $10 / 27 / 00$ & $10 / 30 / 00$ & 2 days $12 \mathrm{hrs} 21 \mathrm{mins}$ \\
\hline 2001 & NPT & JAH00304.NT1 & 3D9.1BF0FF2FA2 & $10 / 27 / 00$ & $10 / 30 / 00$ & 2 days $12 \mathrm{hrs} 21 \mathrm{mins}$ \\
\hline 2001 & NPT & JAH00304.NT1 & 3D9.1BF100574D & $10 / 27 / 00$ & $10 / 30 / 00$ & 2 days $12 \mathrm{hrs} 21 \mathrm{mins}$ \\
\hline 2001 & NPT & JAH00313.NT1 & 3D9.1BF0FF0ED5 & $10 / 27 / 00$ & $11 / 8 / 00$ & 11 days $12 \mathrm{hrs} 47 \mathrm{mins}$ \\
\hline 2001 & NPT & JAH00314.NT1 & 3D9.1BF0FF35BD & $10 / 27 / 00$ & $11 / 9 / 00$ & 12 days $13 \mathrm{hrs} 1 \mathrm{mins}$ \\
\hline 2001 & NPT & JAH00312.NT1 & 3D9.1BF0FF31A7 & $10 / 30 / 00$ & $11 / 7 / 00$ & 7 days $15 \mathrm{hrs} 53 \mathrm{mins}$ \\
\hline 2001 & NPT & JAH00312.NT1 & 3D9.1BF0FF45E5 & $11 / 1 / 00$ & $11 / 7 / 00$ & 5 days $15 \mathrm{hrs} 53 \mathrm{mins}$ \\
\hline 2001 & NPT & JAH00314.NT1 & 3D9.1BF0FF0DD1 & $11 / 1 / 00$ & $11 / 9 / 00$ & 7 days $16 \mathrm{hrs} 1 \mathrm{mins}$ \\
\hline 2001 & NPT & JAH00312.NT1 & 3D9.1BF0FF39D4 & $11 / 2 / 00$ & $11 / 7 / 00$ & 4 days 15 hrs 53 mins \\
\hline 2001 & NPT & JAH00312.NT1 & 3D9.1BF0FF4653 & $11 / 2 / 00$ & $11 / 7 / 00$ & 4 days 15 hrs 53 mins \\
\hline 2001 & NPT & JAH00319.NT1 & 3D9.1BF0FF308D & $11 / 3 / 00$ & $11 / 14 / 00$ & 10 days $18 \mathrm{hrs} 59 \mathrm{mins}$ \\
\hline 2001 & NPT & JAH00320.NT1 & 3D9.1BF0FF2ECB & $11 / 3 / 00$ & $11 / 15 / 00$ & 11 days $19 \mathrm{hrs} 10 \mathrm{mins}$ \\
\hline 2001 & NPT & JAH00320.NT1 & 3D9.1BF0FF449C & $11 / 3 / 00$ & $11 / 15 / 00$ & 11 days $19 \mathrm{hrs} 10 \mathrm{mins}$ \\
\hline 2001 & NPT & JAH00320.NT1 & 3D9.1BF0FF423A & $11 / 3 / 00$ & $11 / 15 / 00$ & 11 days $19 \mathrm{hrs} 10 \mathrm{mins}$ \\
\hline 2002 & ODFW & JAH01312.NT1 & 3D9.1BF11B9839 & $8 / 27 / 01$ & $11 / 8 / 01$ & 72 days 1 hrs 59 mins \\
\hline 2002 & ODFW & JAH01298.NT1 & 3D9.1BF11AD2B1 & $8 / 28 / 01$ & $10 / 25 / 01$ & 57 days 19 hrs 48 mins \\
\hline 2002 & ODFW & JAH01312.NT1 & 3D9.1BF11C0E1B & $8 / 28 / 01$ & $11 / 8 / 01$ & 71 days $20 \mathrm{hrs} 57 \mathrm{mins}$ \\
\hline 2002 & ODFW & JAH01298.NT1 & 3D9.1BF11B5A1B & $8 / 28 / 01$ & $10 / 25 / 01$ & 57 days $17 \mathrm{hrs} 40 \mathrm{mins}$ \\
\hline 2002 & ODFW & JAH01312.NT1 & 3D9.1BF11C06D1 & $8 / 28 / 01$ & $11 / 8 / 01$ & 71 days $17 \mathrm{hrs} 19$ mins \\
\hline 2002 & ODFW & JAH01304.NTA & 3D9.1BF11BFC41 & $8 / 28 / 01$ & $10 / 31 / 01$ & 64 days 5 hrs 32 mins \\
\hline
\end{tabular}

C -12 


\section{APPENDIX D}

STATISTICAL COMPARISONS OF MEDIAN FORK LENGTHS OF NATURAL AND HATCHERY CHINOOK SALMON AND STEELHEAD SMOLTS CAPTURED IN THE IMNAHA RIVER SMOLT TRAPS DURING MIGRATION YEARS 2001 AND 2002

D - 1 
Appendix D. Table D1. Statistical comparisons of median fork lengths between groups of smolts captured in the Imnaha River smolt traps during migration years 2001 and 2002.

\begin{tabular}{|c|c|c|c|c|c|c|c|}
\hline \multirow{2}{*}{ Group 1} & \multirow{2}{*}{ Group 2} & \multicolumn{2}{|c|}{ Sample Sizes } & \multicolumn{2}{|c|}{$\begin{array}{l}\text { Median Fork } \\
\text { Length }(\mathrm{mm})\end{array}$} & \multirow{2}{*}{$\begin{array}{l}\text { Wilcoxon } \\
\text { Value } \\
\text { (W) }\end{array}$} & \multirow{2}{*}{$\begin{array}{c}\text { Significance } \\
\text { Level } \\
p=0.05\end{array}$} \\
\hline & & Group 1 & Group 2 & Group 1 & Group 2 & & \\
\hline $\begin{array}{l}\text { Natural Chinook Salmon - } \\
\text { Upper Trap - Fall of } 2000\end{array}$ & $\begin{array}{l}\text { Natural Chinook Salmon - } \\
\text { Upper Trap - Fall of } 2001\end{array}$ & 1,788 & 1,385 & 86 & 76 & 555,111 & $\mathrm{p}<0.05$ \\
\hline $\begin{array}{l}\text { Natural Chinook Salmon - } \\
\text { Lower Trap - Fall of } 2000\end{array}$ & $\begin{array}{l}\text { Natural Chinook Salmon - } \\
\text { Lower Trap - Fall of } 2001\end{array}$ & 1,994 & 1,888 & 90 & 85 & $1.27\left(10^{6}\right)$ & $\mathrm{p}<0.05$ \\
\hline $\begin{array}{l}\text { Natural Chinook Salmon - } \\
\text { Upper Trap - Fall of } 2000\end{array}$ & $\begin{array}{l}\text { Natural Chinook Salmon - } \\
\text { Lower Trap - Fall of } 2000\end{array}$ & 1,788 & 1,994 & 86 & 90 & $1.29\left(10^{6}\right)$ & $\mathrm{p}<0.05$ \\
\hline $\begin{array}{l}\text { Natural Chinook Salmon - } \\
\text { Upper Trap - Fall of } 2001\end{array}$ & $\begin{array}{l}\text { Natural Chinook Salmon - } \\
\text { Lower Trap - Fall of } 2001\end{array}$ & 1,385 & 1,888 & 76 & 85 & $1.93\left(10^{6}\right)$ & $\mathrm{p}>0.05$ \\
\hline $\begin{array}{c}\text { Hatchery Chinook Salmon - } \\
\text { Lower Trap - Spring of } \\
2001\end{array}$ & $\begin{array}{c}\text { Natural Chinook Salmon - } \\
\text { Lower Trap - Spring of } \\
2001\end{array}$ & 7,107 & 9,956 & 140 & 108 & 872,531 & $\mathrm{p}<0.05$ \\
\hline $\begin{array}{c}\text { Hatchery Steelhead - Lower } \\
\text { Trap - Spring of } 2001\end{array}$ & $\begin{array}{l}\text { Natural Steelhead - Lower } \\
\text { Trap - Spring of } 2001\end{array}$ & 4,365 & 3,733 & 217 & 175 & $1.97\left(10^{6}\right)$ & $\mathrm{p}<0.05$ \\
\hline $\begin{array}{c}\text { Hatchery Chinook Salmon - } \\
\text { Lower Trap - Spring of } \\
2002\end{array}$ & $\begin{array}{c}\text { Natural Chinook Salmon - } \\
\text { Lower Trap - Spring of } \\
2002\end{array}$ & 3,918 & 2,333 & 136 & 104 & 192,487 & $\mathrm{p}<0.05$ \\
\hline $\begin{array}{c}\text { Hatchery Steelhead - Lower } \\
\text { Trap - Spring of } 2002\end{array}$ & $\begin{array}{l}\text { Natural Steelhead - Lower } \\
\text { Trap - Spring of } 2002\end{array}$ & 2,428 & 4,738 & 217 & 172 & 724,674 & $\mathrm{p}<0.05$ \\
\hline
\end{tabular}




\section{APPENDIX E}

IMNAHA RIVER JUVENILE HATCHERY CHINOOK SALMON POST RELEASE

SURVIVAL ESTIMATES FROM 1994 TO 2002 AND DAILY TRAP EFFICIENCIES FOR MIGRATION YEARS 2001 AND 2002

E - 1 
Appendix E. Table E1. The number of trap efficiency trials, mean trap efficiency, PIT tag interrogation percentage and estimated survival of hatchery chinook salmon from release at the Imnaha River Acclimation Facility (rkm 74) to the Imnaha River trap (rkm 7), and from release to Lower Granite Dam from 1994 to 2002.

\begin{tabular}{ccccccc}
\hline Year & $\begin{array}{c}\text { Number } \\
\text { of Trials }\end{array}$ & $\begin{array}{c}\text { Mean Trap } \\
\text { Efficiency } \\
(\%)\end{array}$ & $\begin{array}{c}\text { PIT Tag } \\
\text { Interrogations } \\
\text { at the Screw } \\
\text { Trap }(\%)\end{array}$ & $\begin{array}{c}\text { Release to Trap } \\
\text { SURPH } \\
(\%)\end{array}$ & $\begin{array}{c}\text { Eootstrap } \\
(\%)\end{array}$ & $\begin{array}{c}\text { Release to } \\
\text { Granite } \\
\text { Dam }(\%)^{1}\end{array}$ \\
\hline 2002 & 39 & 9.1 & 7.3 & 90.2 & 95.5 & 67.1 \\
2001 & 6 & 29.1 & 12.0 & 93.9 & 45.0 & 74.7 \\
2000 & 11 & 18.1 & 9.8 & 94.7 & 66.9 & 68.7 \\
1999 & 51 & 21.8 & 4.5 & 93.7 & 45.9 & 68.5 \\
1998 & 9 & 29.4 & 17.0 & 88.4 & 66.9 & 68.3 \\
1997 & 6 & 45.9 & 19.6 & 89.2 & 44 & 61.6 \\
1996 & 9 & 11.6 & 10.6 & 95.0 & 101.7 & 56.8 \\
1995 & 7 & 14.8 & 10.8 & 92.6 & 68 & 61.8 \\
1994 & 1 & 13.8 & 6.2 & 100.9 & 88.1 & 68.5 \\
\hline
\end{tabular}

${ }^{1}$ Estimated as the product of the SURPH Survival estimates from release to the Imnaha River trap, and from the trap to Lower Granite Dam.

Appendix E. Table E2. Daily trap efficiency trials of hatchery chinook salmon released and recaptured in the lower Imnaha River trap during the spring of 2001 migration year.

\begin{tabular}{ccccc}
\hline $\begin{array}{c}\text { Sample End } \\
\text { Date }\end{array}$ & Hours Fished & Released & Recaptured & Efficiency \\
\hline $3 / 28 / 2001$ & 21 & 204 & 45 & 22.1 \\
$4 / 2 / 2001$ & 19.5 & 277 & 107 & 38.6 \\
$4 / 5 / 2001$ & 21.5 & 200 & 73 & 36.5 \\
$4 / 6 / 2001$ & 25 & 304 & 79 & 26.0 \\
$4 / 7 / 2001$ & 24 & 37 & 1 & 2.7 \\
$4 / 8 / 2001$ & 26.5 & 27 & 0 & 0.0 \\
\hline & Total & 1,049 & 305 & 29.1 \\
& & & &
\end{tabular}


Appendix E. Table E3. Daily trap efficiency trials of hatchery and natural chinook salmon released and recaptured in the lower Imnaha River trap during the spring of 2002 migration year.

\begin{tabular}{|c|c|c|c|c|c|c|c|}
\hline \multirow{2}{*}{$\begin{array}{c}\text { Sample End } \\
\text { Date }\end{array}$} & \multirow{2}{*}{$\begin{array}{l}\text { Hours } \\
\text { Fished }\end{array}$} & \multicolumn{3}{|c|}{ Hatchery Chinook Salmon } & \multicolumn{3}{|c|}{ Natural Chinook Salmon } \\
\hline & & Released & Recaptured & Efficiency & Released & Recaptured & Efficiency \\
\hline $3 / 25 / 2002$ & 25 & 59 & 4 & 6.8 & 2 & 1 & 50.0 \\
\hline $3 / 26 / 2002$ & 26 & 36 & 4 & 11.1 & 18 & 1 & 5.6 \\
\hline $3 / 27 / 2002$ & 23 & 35 & 10 & 28.6 & 12 & 2 & 16.7 \\
\hline $3 / 28 / 2002$ & 23 & 41 & 5 & 12.2 & 29 & 1 & 3.4 \\
\hline $3 / 29 / 2002$ & 22.5 & 30 & & 0.0 & 17 & & 0.0 \\
\hline $3 / 31 / 2002$ & 18.75 & 31 & 2 & 6.5 & 27 & & 0.0 \\
\hline $4 / 1 / 2002$ & 24 & 44 & 4 & 9.1 & 2 & 1 & 50.0 \\
\hline $4 / 3 / 2002$ & 18 & 29 & & 0.0 & 29 & 1 & 3.4 \\
\hline $4 / 4 / 2002$ & 15 & 28 & & 0.0 & 27 & 2 & 7.4 \\
\hline $4 / 5 / 2002$ & 23 & 39 & & 0.0 & 24 & & 0.0 \\
\hline $4 / 7 / 2002$ & 16.3 & 49 & & 0.0 & 7 & & 0.0 \\
\hline $4 / 8 / 2002$ & 24.5 & 27 & 10 & 37.0 & 25 & 3 & 12.0 \\
\hline 4/9/2002 & 25 & 27 & 6 & 22.2 & 29 & 2 & 6.9 \\
\hline $4 / 10 / 2002$ & 20.5 & 29 & 4 & 13.8 & 29 & 2 & 6.9 \\
\hline 4/11/2002 & 24 & 30 & & 0.0 & 30 & 1 & 3.3 \\
\hline $4 / 12 / 2002$ & 10 & 60 & 2 & 3.3 & 4 & 2 & 50.0 \\
\hline 4/13/2002 & 11 & & & & 19 & & 0.0 \\
\hline 4/17/2002 & 11 & 50 & & 0.0 & 5 & & 0.0 \\
\hline 4/18/2002 & 14 & 36 & 5 & 13.9 & 6 & & 0.0 \\
\hline 4/19/2002 & 24.5 & 25 & 5 & 20.0 & 30 & 1 & 3.3 \\
\hline 4/20/2002 & 24 & 31 & 1 & 3.2 & 35 & 3 & 8.6 \\
\hline $4 / 21 / 2002$ & 23.5 & 31 & 5 & 16.1 & 30 & 2 & 6.7 \\
\hline $4 / 22 / 2002$ & 25 & 32 & 7 & 21.9 & 29 & 3 & 10.3 \\
\hline $4 / 23 / 2002$ & 26.5 & 28 & 1 & 3.6 & 25 & 2 & 8.0 \\
\hline $4 / 24 / 2002$ & 24.5 & & & & 30 & & 0.0 \\
\hline $4 / 25 / 2002$ & 23 & 30 & 3 & 10.0 & 31 & 3 & 9.7 \\
\hline $4 / 26 / 2002$ & 24 & 28 & 4 & 14.3 & 30 & 7 & 23.3 \\
\hline 4/29/2002 & 20 & 31 & 6 & 19.4 & 30 & 3 & 10.0 \\
\hline 4/30/2002 & 24.5 & 30 & 5 & 16.7 & & & \\
\hline $5 / 1 / 2002$ & 24 & 30 & 6 & 20.0 & 29 & 6 & 20.7 \\
\hline $5 / 2 / 2002$ & 20.5 & 50 & 2 & 4.0 & 45 & & 0.0 \\
\hline $5 / 3 / 2002$ & 23 & & & & 12 & 1 & 8.3 \\
\hline $5 / 7 / 2002$ & 23 & 21 & & 0.0 & & & \\
\hline $5 / 8 / 2002$ & 25.5 & 19 & 1 & 5.3 & 15 & 1 & 6.7 \\
\hline $5 / 9 / 2002$ & 24.75 & 15 & & 0.0 & 17 & & 0.0 \\
\hline $5 / 12 / 2002$ & 12.25 & 1 & & 0.0 & 15 & 3 & 20.0 \\
\hline $5 / 13 / 2002$ & 24 & 5 & & 0.0 & 25 & 1 & 4.0 \\
\hline $5 / 14 / 2002$ & 24.75 & 4 & & 0.0 & 21 & 1 & 4.8 \\
\hline $5 / 15 / 2002$ & 13.75 & 10 & & 0.0 & & & \\
\hline $5 / 16 / 2002$ & 22 & 6 & & 0.0 & & & \\
\hline $5 / 17 / 2002$ & 24.5 & 6 & & 0.0 & & & \\
\hline $5 / 18 / 2002$ & 11.5 & 5 & & 0.0 & & & \\
\hline & Total & 1,118 & 102 & 9.1 & 790 & 56 & 7.1 \\
\hline
\end{tabular}


APPENDIX F

ARRIVAL TIMING AT SNAKE RIVER AND COLUMBIA RIVER DAMS

F -1 
Appendix F. Table F1. A statistical comparison of median arrival times of natural chinook salmon at Lower Granite Dam between groups of natural chinook salmon released at the upper and lower Imnaha River traps and between fall and spring releases for migration years 2001 and 2002.

\begin{tabular}{|c|c|c|c|c|c|c|c|}
\hline \multirow{2}{*}{ Group 1} & \multirow{2}{*}{ Group 2} & \multicolumn{2}{|c|}{ Sample Sizes } & \multicolumn{2}{|c|}{ Median Arrival Time } & \multirow{2}{*}{$\begin{array}{l}\text { Wilcoxon } \\
\text { Value } \\
\text { (W) }\end{array}$} & \multirow{2}{*}{$\begin{array}{c}\text { Significance } \\
\text { Level } \\
p=0.05\end{array}$} \\
\hline & & Group 1 & Group 2 & Group 1 & Group 2 & & \\
\hline $\begin{array}{l}\text { Natural Chinook Salmon - } \\
\text { Lower Trap - Fall of } 2000\end{array}$ & $\begin{array}{l}\text { Natural Chinook Salmon - } \\
\text { Upper Trap - Fall of } 2000\end{array}$ & 644 & 429 & April 26 & April 29 & 75,625 & 0.00 \\
\hline $\begin{array}{l}\text { Natural Chinook Salmon - } \\
\text { Lower Trap - Spring } 2001\end{array}$ & $\begin{array}{l}\text { Natural Chinook Salmon - } \\
\text { Lower Trap - Fall of } 2000\end{array}$ & 6,772 & 644 & April 28 & April 26 & $1.58\left(10^{6}\right)$ & 0.00 \\
\hline $\begin{array}{l}\text { Natural Chinook Salmon - } \\
\text { Lower Trap - Spring } 2001\end{array}$ & $\begin{array}{l}\text { Natural Chinook Salmon - } \\
\text { Upper Trap - Fall of } 2000\end{array}$ & 6,772 & 429 & April 28 & April 29 & $1.21\left(10^{6}\right)$ & 0.00 \\
\hline $\begin{array}{l}\text { Natural Chinook Salmon - } \\
\text { Lower Trap - Fall of } 2001\end{array}$ & $\begin{array}{l}\text { Natural Chinook Salmon - } \\
\text { Upper Trap - Fall of } 2001\end{array}$ & 162 & 60 & April 16 & May 5 & 1,475 & 0.00 \\
\hline $\begin{array}{l}\text { Natural Chinook Salmon - } \\
\text { Lower Trap - Spring } 2002\end{array}$ & $\begin{array}{l}\text { Natural Chinook Salmon - } \\
\text { Lower Trap - Fall of } 2001\end{array}$ & 489 & 162 & May 5 & April 16 & 14,373 & 0.00 \\
\hline $\begin{array}{l}\text { Natural Chinook Salmon - } \\
\text { Lower Trap - Spring } 2002\end{array}$ & $\begin{array}{l}\text { Natural Chinook Salmon - } \\
\text { Upper Trap - Fall of } 2001\end{array}$ & 489 & 60 & May 5 & May 5 & 14,931 & 0.82 \\
\hline
\end{tabular}


Appendix F. Table F2. A statistical comparison of cumulative arrival timing of natural chinook salmon at Lower Granite Dam between groups of natural chinook salmon released at the upper and lower Imnaha River traps and between fall and spring releases for migration years 2001 and 2002.

\begin{tabular}{|c|c|c|c|c|c|c|}
\hline \multirow{2}{*}{ Group 1} & \multirow{2}{*}{ Group 2} & \multicolumn{2}{|c|}{ Sample Sizes } & \multirow{2}{*}{$\begin{array}{l}\text { Maximum Distance } \\
\text { Between Cumulative } \\
\text { Distributions }\end{array}$} & \multirow{2}{*}{$\begin{array}{l}\text { Kolmogorov - } \\
\text { Smirnov Test }\end{array}$} & \multirow{2}{*}{$\begin{array}{l}\text { Significance Level } \\
\qquad \mathrm{p}=0.05\end{array}$} \\
\hline & & Group 1 & Group 2 & & & \\
\hline $\begin{array}{l}\text { Natural Chinook Salmon - } \\
\text { Lower Trap - Fall of } 2000\end{array}$ & $\begin{array}{l}\text { Natural Chinook Salmon - } \\
\text { Upper Trap - Fall of } 2000\end{array}$ & 644 & 429 & 0.423 & 6.785 & 0.00 \\
\hline $\begin{array}{l}\text { Natural Chinook Salmon - } \\
\text { Lower Trap - Spring } 2001\end{array}$ & $\begin{array}{l}\text { Natural Chinook Salmon - } \\
\text { Lower Trap - Fall of } 2000\end{array}$ & 6,772 & 644 & 0.313 & 7.581 & 0.00 \\
\hline $\begin{array}{l}\text { Natural Chinook Salmon - } \\
\text { Lower Trap - Spring } 2001\end{array}$ & $\begin{array}{l}\text { Natural Chinook Salmon - } \\
\text { Upper Trap - Fall of } 2000\end{array}$ & 6,772 & 429 & 0.217 & 4.365 & 0.00 \\
\hline $\begin{array}{l}\text { Natural Chinook Salmon - } \\
\text { Lower Trap - Fall of } 2001\end{array}$ & $\begin{array}{l}\text { Natural Chinook Salmon - } \\
\text { Upper Trap - Fall of } 2001\end{array}$ & 162 & 60 & 0.582 & 3.852 & 0.00 \\
\hline $\begin{array}{l}\text { Natural Chinook Salmon - } \\
\text { Lower Trap - Spring } 2002\end{array}$ & $\begin{array}{l}\text { Natural Chinook Salmon - } \\
\text { Lower Trap - Fall of } 2001\end{array}$ & 489 & 162 & 0.593 & 6.539 & 0.00 \\
\hline $\begin{array}{l}\text { Natural Chinook Salmon - } \\
\text { Lower Trap - Spring } 2002\end{array}$ & $\begin{array}{l}\text { Natural Chinook Salmon - } \\
\text { Upper Trap - Fall of } 2001\end{array}$ & 489 & 60 & 0.152 & 1.112 & 0.17 \\
\hline
\end{tabular}


Appendix F. Table F3. Arrival timing of PIT tagged Imnaha River natural chinook salmon smolts, tagged and released in the fall at the upper trap site at Lower Granite, Little Goose, Lower Monumental, and McNary dams from 1998 to 2002.

\begin{tabular}{lccccc}
\hline & & Sample Size & & \multicolumn{2}{c}{ Arrival Timing } \\
Trap Site and Dam & Year & (n) & Date Range & Median & $90 \%$ \\
\hline Lower Granite & 2002 & 60 & April 13 - May 27 & May 5 & May 20 \\
& 2001 & 429 & April 7 - June 9 & April 29 & May 14 \\
& 2000 & 245 & April 8 - May 28 & May 1 & May 10 \\
& 1999 & 128 & April 8 - May 27 & May 1 & May 17 \\
& 1998 & 454 & April 3 - June 5 & April 27 & May 9 \\
Little Goose & 2002 & 78 & April 21 - June 10 & May 7 & May 22 \\
& 2001 & 85 & April 20 - June 1 & May 7 & May 18 \\
& 2000 & 128 & April 14 - June 4 & May 28 & May 11 \\
& 1999 & 220 & April 10 - June 21 & April 30 & May 18 \\
& 1998 & 410 & April 14 - May 28 & May 4 & May 15 \\
& 2002 & 44 & April 30 - June 12 & May 11 & May 22 \\
Lower Monumental & 2001 & 7 & May 1 - May 19 & NA & NA \\
& 2000 & 40 & April 17 - May 30 & May 29 & May 21 \\
& 1999 & 80 & April 13 - May 28 & May 2 & May 20 \\
& 1998 & 304 & April 15 - May 29 & May 7 & May 19 \\
& 2002 & 32 & April 27 - May 25 & May 12 & May 17 \\
& 2001 & 3 & May 21 - June 25 & NA & NA \\
& 2000 & 42 & April 26 - May 31 & May 10 & May 21 \\
& 1999 & 18 & April 18 - May 30 & May 9 & May 25 \\
& 1998 & 195 & April 18 - June 4 & May 4 & May 18 \\
& & & &
\end{tabular}


Appendix F. Table F4. Arrival timing of PIT tagged Imnaha River natural chinook salmon smolts, tagged and released in the fall at the lower trap site at Lower Granite, Little Goose, Lower Monumental, and McNary dams from 1998 to 2002.

\begin{tabular}{lccccc} 
& & & & \multicolumn{2}{c}{ Arrival Timing } \\
Trap Site and Dam & Year & (n) & Date Range & Median & $90 \%$ \\
\hline Lower Granite & 2002 & 162 & April 1 - May 20 & April 16 & May 30 \\
& 2001 & 644 & April 3 - May 26 & April 26 & April 30 \\
& 2000 & 262 & April 4 - May 12 & April 14 & April 23 \\
& 1999 & 103 & April 3 - May 2 & April 19 & April 25 \\
& 1998 & 428 & March 27 - May 12 & April 14 & April 24 \\
Little Goose & 2002 & 159 & April 13 - May 16 & May 1 & May 5 \\
& 2001 & 135 & April 23 - June 16 & April 30 & May 11 \\
& 2000 & 239 & April 12 - May 12 & April 17 & April 24 \\
& 1999 & 364 & April 8 - May 9 & April 19 & April 25 \\
& 1998 & 228 & April 11 - May 12 & April 25 & May 2 \\
& & & & & \\
Lower Monumental & 2002 & 100 & April 30 - June 4 & May 5 & May 16 \\
& 2001 & 21 & April 28 - May 17 & NA & NA \\
& 2000 & 62 & April 13 - May 6 & April 21 & April 26 \\
& 1999 & 144 & April 10 - May 21 & April 19 & April 25 \\
& 1998 & 202 & April 19 - May 19 & Apr 25 & May 4 \\
& 2002 & 86 & April 21 - May 26 & May 5 & May 15 \\
& 2001 & 5 & May 5 - May 18 & NA & NA \\
& 2000 & 35 & April 18 - May 6 & April 27 & May 4 \\
& 1999 & 64 & April 10 - May 10 & April 21 & April 28 \\
& 1998 & 236 & April 20 - May 23 & April 30 & May 4 \\
\hline & & & & &
\end{tabular}


Appendix F. Table F5. Arrival timing of spring PIT tagged Imnaha River natural chinook salmon smolts at Lower Granite, Little Goose, Lower Monumental, and McNary dams from 1993 to 2002.

\begin{tabular}{|c|c|c|c|c|c|}
\hline \multirow[b]{2}{*}{ Dam } & \multicolumn{2}{|c|}{ Sample Size } & \multirow[b]{2}{*}{ Date Range } & \multicolumn{2}{|c|}{ Arrival Timing } \\
\hline & Year & (n) & & Median & $90 \%$ \\
\hline \multirow[t]{10}{*}{ Lower Granite } & 2002 & 489 & April 2 - June 27 & May 5 & May 20 \\
\hline & 2001 & 6,857 & March 30 - August 13 & April 28 & May 12 \\
\hline & 2000 & 1,291 & April 2 - August 8 & April 22 & May 11 \\
\hline & 1999 & 1,218 & March 28 - July 15 & April 27 & May 22 \\
\hline & 1998 & 1,630 & April 1 - June 27 & April 25 & May 6 \\
\hline & 1997 & 74 & April 6 - May 18 & April 22 & May 11 \\
\hline & 1996 & 421 & April 6 - June 12 & April 30 & May 18 \\
\hline & 1995 & 184 & April 11 - July 11 & May 1 & May 11 \\
\hline & 1994 & 348 & April 14 - June 23 & April 24 & May 11 \\
\hline & 1993 & 109 & April 21 - June 12 & May 4 & May 14 \\
\hline \multirow[t]{10}{*}{ Little Goose } & 2002 & 519 & April 15 - June 20 & May 7 & May 23 \\
\hline & 2001 & 1,216 & April 16 - July 23 & May 2 & May 17 \\
\hline & 2000 & 1,103 & April 11 - July 14 & April 23 & May 11 \\
\hline & 1999 & 2,099 & April 9 - August 1 & April 29 & May 22 \\
\hline & 1998 & 837 & April 14 - June 25 & May 3 & May 12 \\
\hline & 1997 & 70 & April 15 - May 22 & April 26 & May 11 \\
\hline & 1996 & 358 & April 12 - June 16 & April 27 & May 20 \\
\hline & 1995 & 144 & April 15 - July 15 & May 7 & May 20 \\
\hline & 1994 & 194 & April 23 - June 17 & April 28 & May 7 \\
\hline & 1993 & 46 & April 27 - June 2 & May 3 & May 16 \\
\hline \multirow[t]{10}{*}{ Lower Monumental } & 2002 & 336 & April 22 - June 14 & May 13 & May 22 \\
\hline & 2001 & 131 & April 28 - July 18 & May 13 & May 20 \\
\hline & 2000 & 335 & April 13 - July 12 & April 25 & May 29 \\
\hline & 1999 & 688 & April 9 - August 4 & May 1 & May 23 \\
\hline & 1998 & 289 & April 19 - June 8 & April 30 & May 11 \\
\hline & 1997 & 74 & April 20 - June 1 & April 30 & May 14 \\
\hline & 1996 & 359 & April 13 - June 15 & May 10 & May 22 \\
\hline & 1995 & 142 & April 19 - August 4 & May 8 & June 4 \\
\hline & 1994 & 215 & April 25 - July 26 & May 1 & May 24 \\
\hline & 1993 & 37 & May 3 - June 2 & May 8 & May 13 \\
\hline \multirow[t]{10}{*}{ McNary } & 2002 & 189 & April 23 - June 10 & May 14 & May 23 \\
\hline & 2001 & 45 & April 29 - June 5 & May 18 & May 31 \\
\hline & 2000 & 192 & April 18 - July 4 & May 7 & May 29 \\
\hline & 1999 & 152 & April 18 - June 27 & May 6 & May 21 \\
\hline & 1998 & 187 & April 19 - June 2 & May 1 & May 15 \\
\hline & 1997 & 24 & April 22 - May 19 & May 1 & May 12 \\
\hline & 1996 & 148 & April 19 - June 8 & May 14 & May 24 \\
\hline & 1995 & 89 & April 28 - July 9 & May 12 & May 21 \\
\hline & 1994 & 229 & April 29 - July 16 & May 12 & May 28 \\
\hline & 1993 & 20 & May 3 - June 15 & May 9 & May 21 \\
\hline
\end{tabular}

F -6 
Appendix F. Table F6. Arrival timing of PIT tagged Imnaha River hatchery chinook salmon smolts at Lower Granite, Little Goose, Lower Monumental, and McNary dams from 1992 to 2002.

\begin{tabular}{|c|c|c|c|c|c|}
\hline \multirow[b]{2}{*}{ Dam } & \multicolumn{3}{|c|}{ Sample Size } & \multicolumn{2}{|c|}{ Arrival Timing } \\
\hline & Year & (n) & Date Range & Median & $90 \%$ \\
\hline \multirow[t]{11}{*}{ Lower Granite } & 2002 & 461 & April 1 - May 23 & May 7 & May 19 \\
\hline & 2001 & 1,725 & March 31 - May 27 & April 29 & May 10 \\
\hline & 2000 & 782 & April 7 - May 24 & May 3 & May 13 \\
\hline & 1999 & 267 & April 18 - May 25 & May 5 & May 14 \\
\hline & 1998 & 696 & April 15 - May 22 & May 2 & May 9 \\
\hline & 1997 & 227 & April 16 - May 22 & May 5 & May 14 \\
\hline & 1996 & 169 & April 13 - May 26 & May 7 & May 16 \\
\hline & $1995^{1}$ & 128 & April 13 - June 7 & May 2 & May 13 \\
\hline & $1995^{2}$ & 83 & April 16 - May 22 & May 8 & May 15 \\
\hline & 1994 & 129 & April 24 - May 18 & May 12 & May 12 \\
\hline & $1992^{3}$ & 273 & April 12 - June 6 & April 21 & May 6 \\
\hline \multirow[t]{11}{*}{ Little Goose } & 2002 & 544 & April 13 - June 1 & May 12 & May 22 \\
\hline & 2001 & 509 & April 15 - May 29 & May 7 & May 16 \\
\hline & 2000 & 450 & April 14 - May 24 & May 3 & May 13 \\
\hline & 1999 & 387 & April 16 - June 6 & May 10 & May 19 \\
\hline & 1998 & 391 & April 25 - May 26 & May 7 & May 14 \\
\hline & 1997 & 267 & April 20 - May 27 & May 9 & May 18 \\
\hline & 1996 & 131 & April 23 - June 6 & May 13 & May 20 \\
\hline & $1995^{1}$ & 114 & April 26 - June 11 & May 10 & May 20 \\
\hline & $1995^{2}$ & 67 & April 27 - June 7 & May 12 & May 23 \\
\hline & 1994 & 65 & April 28 - June 2 & May 14 & May 21 \\
\hline & $1992^{3}$ & 116 & April 17 - May 22 & April 27 & May 5 \\
\hline \multirow[t]{10}{*}{ Lower Monumental } & 2002 & 457 & April 30 - June 11 & May 14 & May 23 \\
\hline & 2001 & 79 & April 27 - June 4 & May 12 & May 25 \\
\hline & 2000 & 107 & April 19 - May 26 & May 5 & May 22 \\
\hline & 1999 & 124 & April 23 - May 25 & May 11 & May 20 \\
\hline & 1998 & 143 & April 23 - May 26 & May 8 & May 15 \\
\hline & 1997 & 199 & April 25 - June 3 & May 10 & May 19 \\
\hline & 1996 & 136 & April 23 - May 29 & May 15 & May 23 \\
\hline & $1995^{1}$ & 106 & April 27 - June 10 & May 12 & May 21 \\
\hline & $1995^{2}$ & 71 & April 29 - June 9 & May 17 & May 26 \\
\hline & 1994 & 73 & April 30 - June 7 & May 14 & May 20 \\
\hline \multirow[t]{11}{*}{ McNary } & 2002 & 220 & April 16 - June 10 & May 15 & May 25 \\
\hline & 2001 & 25 & May 5 - May 31 & NA & NA \\
\hline & 2000 & 99 & April 24 - May 30 & May 13 & May 27 \\
\hline & 1999 & 56 & May 2 - May 26 & May 19 & May 24 \\
\hline & 1998 & 53 & May 2 - May 30 & May 11 & May 19 \\
\hline & 1997 & 61 & May 1 - June 1 & May 10 & May 19 \\
\hline & 1996 & 55 & May 1 - May 27 & May 16 & May 23 \\
\hline & $1995^{1}$ & 67 & April 29 - June 9 & May 16 & May 23 \\
\hline & $1995^{2}$ & 36 & May 3 - May 30 & May 16 & May 22 \\
\hline & 1994 & 119 & May 6 - June 17 & May 21 & May 26 \\
\hline & $1992^{3}$ & 61 & April 27 - June 1 & May 8 & May 17 \\
\hline
\end{tabular}

\footnotetext{
${ }^{1} \mathrm{HxW}$ crossed chinook salmon smolts PIT tagged for NPT and released at dark.
}

${ }^{2} \mathrm{HxW}$ crossed chinook salmon smolts PIT tagged for the FPC and released one hour after tagging and recovery.

${ }^{3}$ Hatchery chinook salmon smolts PIT tagged and released in 1992 were over a two day period only for survival estimation. 
Appendix F. Table F7. Arrival timing of PIT tagged Imnaha River natural steelhead smolts at Lower Granite, Little Goose, Lower Monumental, and McNary dams from 1993 to 2002.

\begin{tabular}{|c|c|c|c|c|c|}
\hline \multirow[b]{2}{*}{ Dam } & \multicolumn{2}{|c|}{ Sample Siz } & \multirow[b]{2}{*}{ Date Range } & \multicolumn{2}{|c|}{ Arrival Timing } \\
\hline & Year & (n) & & Median & $90 \%$ \\
\hline \multirow[t]{11}{*}{ Lower Granite } & 2002 & 979 & April 10 - June 26 & May 18 & May 31 \\
\hline & 2001 & 2,736 & March 29 - September 9 & May 14 & May 18 \\
\hline & 2000 & 2,262 & April 6 - August 3 & May 8 & May 25 \\
\hline & 1999 & 649 & April 19 - June 26 & May 18 & June 5 \\
\hline & 1998 & 1,474 & April 2 - June 12 & May 3 & May 22 \\
\hline & 1997 & 368 & April 20 - July 10 & May 8 & May 24 \\
\hline & 1996 & 537 & April 19 - June 10 & May 6 & June 4 \\
\hline & 1995 & 128 & April 28 - June 19 & May 2 & May 9 \\
\hline & $1994^{1}$ & 332 & April 25 - Aug 15 & May 8 & June 1 \\
\hline & $1994^{2}$ & 207 & May 3 - Aug 20 & May 9 & May 30 \\
\hline & 1993 & 101 & May 3 - June 13 & May 26 & June 8 \\
\hline \multirow[t]{11}{*}{ Little Goose } & 2002 & 856 & April 13 - August 28 & May 21 & June 2 \\
\hline & 2001 & 219 & April 7 - August 19 & May 16 & May 24 \\
\hline & 2000 & 458 & April 11 - June 26 & May 8 & May 29 \\
\hline & 1999 & 717 & April 8 - June 24 & May 21 & May 25 \\
\hline & 1998 & 481 & April 14 - June 19 & May 8 & May 26 \\
\hline & 1997 & 319 & April 20 - June 19 & May 10 & May 26 \\
\hline & 1996 & 365 & April 20 - June 14 & May 9 & May 28 \\
\hline & 1995 & 70 & May 1 - June 23 & May 7 & May 12 \\
\hline & $1994^{1}$ & 159 & April 29 - July 29 & May 12 & May 31 \\
\hline & $1994^{2}$ & 121 & May 6 - July 26 & May 15 & June 1 \\
\hline & 1993 & 48 & May 6 - June 11 & May 24 & June 7 \\
\hline \multirow[t]{11}{*}{ Lower Monumental } & 2002 & 828 & April 30 - August 8 & May 22 & June 3 \\
\hline & 2001 & 23 & May 6 - October 3 & NA & NA \\
\hline & 2000 & 246 & April 12 - August 12 & May 14 & May 30 \\
\hline & 1999 & 342 & April 19 - June 21 & May 23 & May 27 \\
\hline & 1998 & 213 & April 16 - June 11 & May 10 & May 27 \\
\hline & 1997 & 264 & April 21 - June 6 & May 11 & May 25 \\
\hline & 1996 & 397 & April 22 - June 15 & May 14 & May 29 \\
\hline & 1995 & 81 & May 3 - May 17 & May 9 & May 14 \\
\hline & $1994^{1}$ & 148 & May 1 - August 8 & May 12 & July 8 \\
\hline & $1994^{2}$ & 91 & May 9 - July 31 & May 15 & July 10 \\
\hline & 1993 & 43 & May 6 - June 15 & May 30 & June 11 \\
\hline \multirow[t]{11}{*}{ McNary } & 2002 & 124 & April 29 - June 7 & May 22 & May 27 \\
\hline & 2001 & 4 & May 16 - August 5 & NA & NA \\
\hline & 2000 & 58 & April 15 - June 16 & May 24 & June 7 \\
\hline & 1999 & 55 & April 17 - May 31 & May 25 & May 27 \\
\hline & 1998 & 53 & April 20 - June 4 & May 7 & May 28 \\
\hline & 1997 & 62 & April 24 - June 5 & May 13 & May 18 \\
\hline & 1996 & 157 & April 25 - June 11 & May 11 & May 21 \\
\hline & 1995 & 35 & May 5 - May 27 & May 11 & May 17 \\
\hline & $1994^{1}$ & 66 & May 5 - June 22 & May 18 & June 9 \\
\hline & $1994^{2}$ & 42 & May 13 - June 25 & May 18 & June 6 \\
\hline & 1993 & 17 & May 11 - June 13 & May 25 & May 31 \\
\hline
\end{tabular}

\footnotetext{
${ }^{1}$ NPT PIT tagged fish
}

${ }^{2}$ FPC PIT tagged fish 
Appendix F. Table F8. Arrival timing of PIT tagged Imnaha River hatchery steelhead smolts at Lower Granite, Little Goose, Lower Monumental, and McNary dams from 1993 to 2002.

\begin{tabular}{|c|c|c|c|c|c|}
\hline \multirow[b]{2}{*}{ Dam } & \multicolumn{2}{|c|}{ Sample Size } & \multirow[b]{2}{*}{ Date Range } & \multicolumn{2}{|c|}{ Arrival Timing } \\
\hline & Year & (n) & & Median & $90 \%$ \\
\hline \multirow[t]{11}{*}{ Lower Granite } & 2002 & 442 & April 15 - June 27 & May 17 & May 31 \\
\hline & 2001 & 2,541 & April 21 - September 23 & May 16 & May 26 \\
\hline & 2000 & 3,249 & April 8 - July 24 & May 16 & May 25 \\
\hline & 1999 & 1,973 & April 18 - August 5 & May 24 & June 18 \\
\hline & 1998 & 1,683 & April 25 - July 29 & May 15 & May 26 \\
\hline & 1997 & 2,346 & April 19 - July 24 & May 23 & June 13 \\
\hline & 1996 & 440 & April 23 - July 14 & May 28 & June 14 \\
\hline & 1995 & 661 & May 6 - July 12 & May 31 & June 16 \\
\hline & $1994^{1}$ & 164 & April 29 - August 20 & May 29 & July 15 \\
\hline & $1994^{2}$ & 306 & May 6 - August 21 & May 25 & June 23 \\
\hline & 1993 & 224 & May 3 - June 28 & May 17 & May 31 \\
\hline \multirow[t]{11}{*}{ Little Goose } & 2002 & 326 & April 19 - June 29 & May 24 & June 3 \\
\hline & 2001 & 121 & April 28 - October 30 & May 20 & June 21 \\
\hline & 2000 & 309 & April 13 - July 22 & May 22 & July 1 \\
\hline & 1999 & 1,593 & April 20 - August 22 & May 25 & June 18 \\
\hline & 1998 & 555 & May 3 - July 10 & May 25 & May 30 \\
\hline & 1997 & 1,844 & April 21 - August 23 & May 26 & June 13 \\
\hline & 1996 & 261 & April 24 - July 11 & May 25 & June 16 \\
\hline & 1995 & 409 & May 8 - Juyl 13 & Jun 3 & June 20 \\
\hline & $1994^{1}$ & 86 & May 2 - July 30 & May 31 & July 17 \\
\hline & $1994^{2}$ & 165 & May 10 - August 12 & May 27 & July 9 \\
\hline & 1993 & 106 & May 5 - July 8 & May 25 & June 2 \\
\hline \multirow[t]{11}{*}{ Lower Monumental } & 2002 & 406 & April 30 - October 18 & May 28 & June 9 \\
\hline & 2001 & 28 & May 8 - October 25 & NA & NA \\
\hline & 2000 & 243 & April 16 - August 18 & May 25 & July 3 \\
\hline & 1999 & 790 & April 21 - July 20 & May 26 & June 19 \\
\hline & 1998 & 253 & May 5 - July 15 & May 26 & June 3 \\
\hline & 1997 & 1,432 & April 22 - August 6 & May 27 & June 15 \\
\hline & 1996 & 232 & May 6 - July 7 & May 27 & June 15 \\
\hline & 1995 & 410 & May 9 - July 13 & Jun 6 & June 16 \\
\hline & $1994^{1}$ & 30 & May 5 - August 5 & Jun 3 & July 17 \\
\hline & $1994^{2}$ & 75 & May 11 - August 24 & Jun 18 & July 21 \\
\hline & 1993 & 92 & May 7 - June 14 & May 26 & June 5 \\
\hline \multirow[t]{11}{*}{ McNary } & 2002 & 56 & May 2 - June 16 & May 25 & June 6 \\
\hline & 2001 & 8 & May 21 - July 4 & NA & NA \\
\hline & 2000 & 58 & May 3 - July 30 & July 2 & July 17 \\
\hline & 1999 & 79 & April 27 - July 8 & May 28 & May 31 \\
\hline & 1998 & 31 & May 13 - July 2 & Jun 1 & June 19 \\
\hline & 1997 & 245 & April 23 - August 12 & May 27 & June 18 \\
\hline & 1996 & 30 & April 27 - July 3 & May 23 & June 7 \\
\hline & 1995 & 69 & May 15 - July 17 & Jun 5 & June 27 \\
\hline & $1994^{1}$ & 22 & May 17 - July 14 & Jun 5 & July 10 \\
\hline & $1994^{2}$ & 56 & May 20 - July 11 & Jun 17 & July 8 \\
\hline & 1993 & 7 & May 11 - June 5 & May 19 & May 30 \\
\hline
\end{tabular}

${ }^{1}$ NPT PIT tagged fish released at dark

${ }^{1}$ FPC PIT tagged fish released after recovery 
APPENDIX G

MORTALITY AT THE IMNAHA RIVER TRAPS DURING MIGRATION YEARS 2001 AND 2002

$\mathrm{G}-1$ 
Appendix G. Table G1. Mortality of chinook salmon and steelhead smolts due to trapping, handling, and PIT tagging at the upper Imnaha River trap from October 17 to November 15, 2000 .

\begin{tabular}{|c|c|c|c|c|c|c|c|c|}
\hline & \multicolumn{3}{|c|}{ Chinook Salmon } & \multicolumn{5}{|c|}{ Steelhead } \\
\hline & Natural & & Hatchery & & Natural & & Hatchery & \\
\hline Number Captured & 2,318 & & 0 & & 63 & & 0 & \\
\hline Mortality & 69 & & 0 & & 0 & & 0 & \\
\hline Source & $\mathrm{n}$ & $(\%)$ & $\mathrm{n}$ & $(\%)$ & $\mathrm{n}$ & $(\%)$ & $\mathrm{n}$ & $(\%)$ \\
\hline Trapping & 68 & $(2.94)$ & 0 & NA & 0 & $(0.00)$ & 0 & NA \\
\hline Handling & 0 & $(0.00)$ & 0 & NA & 0 & $(0.00)$ & 0 & NA \\
\hline PIT Tagging & 1 & $(0.04)$ & 0 & NA & 0 & $(0.00)$ & 0 & NA \\
\hline Total & 69 & $(2.98)$ & 0 & NA & 0 & $(0.00)$ & 0 & NA \\
\hline
\end{tabular}

Appendix G. Table G2. Mortality of chinook salmon and steelhead smolts due to trapping, handling, and PIT tagging at the lower Imnaha River trap from October 17 to November 15, 2000 .

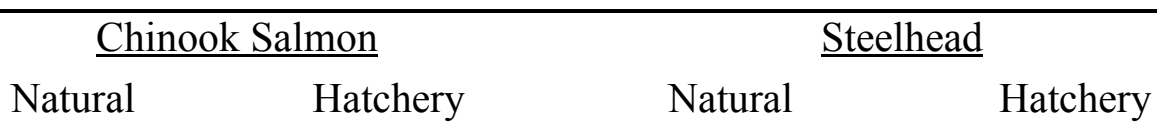

\begin{tabular}{lcccccccc}
\hline Number Captured & 2,981 & & 0 & & 360 & & 0 & \\
Mortality & & & & & & & & \\
Source & $\mathrm{n}$ & $(\%)$ & $\mathrm{n}$ & $(\%)$ & $\mathrm{n}$ & $(\%)$ & $\mathrm{n}$ & $(\%)$ \\
\hline & & & & & & & & \\
Trapping & 7 & $(0.23)$ & 0 & NA & 0 & $(0.00)$ & 0 & NA \\
Handling & 0 & $(0.00)$ & 0 & NA & 0 & $(0.00)$ & 0 & NA \\
PIT Tagging & 1 & $(0.03)$ & 0 & NA & 0 & $(0.00)$ & 0 & NA \\
\hline Total & 8 & $(0.27)$ & 0 & NA & 0 & $(0.00)$ & 0 & NA \\
\hline
\end{tabular}

$\mathrm{G}-2$ 
Appendix G. Table G3. Mortality of chinook salmon and steelhead smolts due to trapping, handling, and PIT tagging from February 22 to June 21, 2001.

\begin{tabular}{|c|c|c|c|c|c|c|c|c|}
\hline & & nook $S$ & mon & & & teelhea & & \\
\hline & Natural & & Hatchery & & Natural & & Hatchery & \\
\hline Number Capt & 10,663 & & 16,097 & & 6,681 & & 28,451 & \\
\hline Mortality & 44 & & 21 & & 5 & & 4 & \\
\hline Source & $\mathrm{n}$ & $(\%)$ & $\mathrm{n}$ & $(\%)$ & $\mathrm{n}$ & (\%) & $\mathrm{n}$ & $(\%)$ \\
\hline Trapping & 23 & $(0.22)$ & 15 & (0.09) & 5 & $(0.07)$ & 4 & $(0.01)$ \\
\hline Handling & 2 & $(0.02)$ & 6 & $(0.04)$ & 0 & $(0.00)$ & 0 & $(0.00)$ \\
\hline PIT Tagging & 19 & $(0.18)$ & 0 & $(0.00)$ & 0 & 0.00 & 0 & $(0.00)$ \\
\hline Total & 44 & $(0.41)$ & 21 & $(0.13)$ & 5 & $(0.07)$ & 4 & $(0.01)$ \\
\hline
\end{tabular}

Appendix G. Table G4. Mortality of chinook salmon and steelhead smolts due to trapping, handling, and PIT tagging at the upper Imnaha River trap from October 17 to November 27, 2001.

\begin{tabular}{|c|c|c|c|c|c|c|c|c|}
\hline & \multicolumn{3}{|c|}{ Chinook Salmon } & \multicolumn{5}{|c|}{ Steelhead } \\
\hline & Natural & & Hatchery & & Natural & & Hatchery & \\
\hline Number Captured & 1,415 & & 0 & & 46 & & 0 & \\
\hline Mortality & 23 & & 0 & & 0 & & 0 & \\
\hline Source & $\mathrm{n}$ & $(\%)$ & $\mathrm{n}$ & $(\%)$ & $\mathrm{n}$ & (\%) & $\mathrm{n}$ & $(\%)$ \\
\hline Trapping & 19 & (1.34) & 0 & NA & 0 & $(0.00)$ & 0 & NA \\
\hline Handling & 1 & $(0.07)$ & 0 & NA & 0 & $(0.00)$ & 0 & NA \\
\hline PIT Tagging & 3 & $(0.21)$ & 0 & NA & 0 & $(0.00)$ & 0 & NA \\
\hline Total & 23 & (1.63) & 0 & NA & 0 & $(0.00)$ & 0 & NA \\
\hline
\end{tabular}

G - 3 
Appendix G. Table G5. Mortality of chinook salmon and steelhead smolts due to trapping, handling, and PIT tagging at the lower Imnaha River trap from October 17 to November 27, 2001.

\begin{tabular}{|c|c|c|c|c|c|c|c|c|}
\hline & \multicolumn{3}{|c|}{ Chinook Salmon } & \multicolumn{5}{|c|}{ Steelhead } \\
\hline & Natural & & Hatchery & & Natural & & Hatchery & \\
\hline Number Captured & 2,149 & & 0 & & 948 & & 0 & \\
\hline Mortality & 3 & & 0 & & 0 & & 0 & \\
\hline Source & $\mathrm{n}$ & $(\%)$ & $\mathrm{n}$ & $(\%)$ & $\mathrm{n}$ & $(\%)$ & $\mathrm{n}$ & $(\%)$ \\
\hline Trapping & 1 & $(0.05)$ & 0 & NA & 0 & $(0.00)$ & 0 & NA \\
\hline Handling & 0 & $(0.00)$ & 0 & NA & 0 & $(0.00)$ & 0 & NA \\
\hline PIT Tagging & 2 & $(0.09)$ & 0 & NA & 0 & $(0.00)$ & 0 & NA \\
\hline Total & 3 & $(0.14)$ & 0 & NA & 0 & $(0.00)$ & 0 & NA \\
\hline
\end{tabular}

Appendix G. Table G6. Mortality of chinook salmon and steelhead smolts due to trapping, handling, and PIT tagging from March 4 to June 14, 2002.

\begin{tabular}{|c|c|c|c|c|c|c|c|c|}
\hline & \multicolumn{3}{|c|}{ Chinook Salmon } & \multicolumn{5}{|c|}{ Steelhead } \\
\hline & Natural & & Hatchery & & Natural & & Hatchery & \\
\hline Number Captured & 2,693 & & 26,407 & & 6,956 & & 25,086 & \\
\hline Mortality & 14 & & 14 & & 5 & & 11 & \\
\hline Source & $\mathrm{n}$ & $(\%)$ & $\mathrm{n}$ & (\%) & $\mathrm{n}$ & $(\%)$ & $\mathrm{n}$ & (\%) \\
\hline Trapping & 7 & $(0.26)$ & 11 & $(0.04)$ & 5 & $(0.07)$ & 11 & $(0.04)$ \\
\hline Handling & 2 & $(0.07)$ & 0 & $(0.00)$ & 0 & $(0.00)$ & 0 & $(0.00)$ \\
\hline PIT Tagging & 5 & $(0.19)$ & 3 & $(0.01)$ & 0 & $(0.00)$ & 0 & $(0.00)$ \\
\hline Total & 14 & $(0.52)$ & 14 & $(0.05)$ & 5 & $(0.07)$ & 11 & $(0.04)$ \\
\hline
\end{tabular}




\section{APPENDIX H}

INCIDENTAL CATCH FOR MIGRATION YEARS 2001 AND 2002

$\mathrm{H}-1$ 
Appendix H. Table H1. The catch of incidental fish during the fall, October 15 to November 15, 2000, and the spring, February 22 to June 21, at the upper and lower Imnaha River juvenile fish traps for the 2001 migration year.

\begin{tabular}{|c|c|c|c|c|c|}
\hline Family & Common Name & $\begin{array}{l}\text { Fall of } 2000 \\
\text { Upper Trap }\end{array}$ & $\begin{array}{l}\text { Fall of } 2000 \\
\text { Lower Trap }\end{array}$ & $\begin{array}{c}\text { Spring of } 2001 \\
\text { Lower Trap }\end{array}$ & Total Catch \\
\hline \multirow[t]{6}{*}{ Salmonidae } & Adult Chinook Salmon & & & & \\
\hline & Adult Steelhead & & & 27 & 27 \\
\hline & Rainbow Trout / Steelhead & 62 & & 61 & 123 \\
\hline & Mountain Whitefish & 33 & 448 & 1 & 482 \\
\hline & Bull Trout & 30 & 62 & 2 & 94 \\
\hline & & & & & 0 \\
\hline \multirow[t]{3}{*}{ Centrarchidae } & Smallmouth Bass & & 22 & 3 & 25 \\
\hline & Bluegill & & & & 0 \\
\hline & & & & & 0 \\
\hline \multirow[t]{4}{*}{ Catostomidae } & Bridgelip Sucker & & 142 & 58 & 200 \\
\hline & Largescale Sucker & & & 30 & 30 \\
\hline & Sucker (unidentified species) & & & 4 & 4 \\
\hline & & & & & 0 \\
\hline \multirow[t]{7}{*}{ Cyprinidae } & Chislemouth & & & 13 & 13 \\
\hline & Longnose Dace & 8 & 92 & 93 & 193 \\
\hline & Speckled Dace & & & 24 & 24 \\
\hline & Leopard Dace & & & & 0 \\
\hline & Northern Pikeminnow & & 44 & 11 & 55 \\
\hline & Redside Shiner & & 9 & 12 & 21 \\
\hline & & & & & 0 \\
\hline \multirow[t]{2}{*}{ Cottidae } & Sculpin (unidentified species) & & 22 & 66 & 88 \\
\hline & & & & & 0 \\
\hline \multirow[t]{2}{*}{ Ictaluridae } & Bullhead (unidentified species) & & & & 0 \\
\hline & Total Catch & 133 & 841 & 405 & 1,379 \\
\hline
\end{tabular}


Appendix H. Table H2. The catch of incidental fish during the fall, October 17 to November 27, 2001, and the spring, March 4 to June 12, at the upper and lower Imnaha River juvenile fish traps for the 2002 migration year.

\begin{tabular}{|c|c|c|c|c|c|}
\hline Family & Common Name & $\begin{array}{l}\text { Fall of } 2001 \\
\text { Upper Trap }\end{array}$ & $\begin{array}{l}\text { Fall of } 2001 \\
\text { Lower Trap }\end{array}$ & $\begin{array}{c}\text { Spring of } 2002 \\
\text { Lower Trap }\end{array}$ & Total Catch \\
\hline \multirow[t]{5}{*}{ Salmonidae } & Adult Chinook Salmon & & 4 & 1 & 5 \\
\hline & Adult Steelhead & & & 91 & 91 \\
\hline & Rainbow Trout / Steelhead & & 577 & 154 & 731 \\
\hline & Mountain Whitefish & 73 & 205 & 22 & 300 \\
\hline & Bull Trout & 12 & 132 & 7 & $\begin{array}{c}151 \\
0\end{array}$ \\
\hline \multirow[t]{2}{*}{ Centrarchidae } & Smallmouth Bass & & 97 & 42 & 139 \\
\hline & Bluegill & & & 2 & $\begin{array}{l}2 \\
0\end{array}$ \\
\hline \multirow[t]{3}{*}{ Catostomidae } & Bridgelip Sucker & & 5 & 47 & 52 \\
\hline & Largescale Sucker & & 809 & 6 & 815 \\
\hline & Sucker (unidentified species) & & 1 & 177 & $\begin{array}{c}178 \\
0\end{array}$ \\
\hline \multirow[t]{6}{*}{ Cyprinidae } & Chislemouth & & 10 & 18 & 28 \\
\hline & Longnose Dace & 4 & 2 & 211 & 217 \\
\hline & Speckled Dace & & 1 & 5 & 6 \\
\hline & Leopard Dace & & 1 & & 1 \\
\hline & Northern Pikeminnow & & 35 & 18 & 53 \\
\hline & Redside Shiner & & 14 & 14 & $\begin{array}{c}28 \\
0\end{array}$ \\
\hline Cottidae & Sculpin (unidentified species) & 1 & 2 & 44 & $\begin{array}{c}47 \\
0\end{array}$ \\
\hline Ictaluridae & Bullhead (unidentified species) & & & 7 & 7 \\
\hline & Total Catch & 90 & 1,895 & 866 & 2,851 \\
\hline
\end{tabular}

